\title{
Resíduos de equipamentos elétricos e eletrônicos em instituições de ensino superior: estudo de caso e diretrizes para a gestão integrada
}

Nivea Maria Vega Longo Reidler

Tese Apresentada ao Programa de Pós-Graduação em Saúde Pública para obtenção do título de

Doutor em Saúde Pública

Área de Concentração: Saúde Ambiental

Orientadora:

$\operatorname{Prof}^{\mathrm{a}} \operatorname{Dr}^{\mathrm{a}}$ Wanda Maria Risso Günther

São Paulo

2012 
É expressamente proibida a comercialização deste documento, tanto na sua forma impressa como eletrônica. Sua reprodução total ou parcial é permitida exclusivamente para fins acadêmicos e científicos, desde que na reprodução figure a identificação do autor, título, instituição e ano da tese. 
Aos meus pais,

Norberto e Neréa.

Aos meus filhos,

Erike Vivian. 


\section{AGRADECIMENTOS}

À Prof ${ }^{a}$ Dra. Wanda Maria Risso Günther, orientadora desta pesquisa de doutorado na USP, por seu interesse e respaldo no desenvolvimento deste trabalho. Aos professores Maria Eugenia Gimenez Boscov (USP), Patrícia Fraga Iglecias Lemos (USP), Lisete Celina Lange (UFMG), Julio Carlos Afonso (UFRJ) e Ednilson Viana, membros da banca examinadora, por sua valiosa contribuição. A todas as pessoas que contribuíram para a realização desta importante etapa de minha formação acadêmica e profissional. Em especial aos professores Dr. José María Quiroga Alonso e D. Enrique Montero Montero, tutores de meu projeto de pesquisa na Universidad de Cádiz (UCA). Agradeço a ambos, por sua amabilidade, profissionalismo, dedicação e paciência, durante minha estadia na UCA. À Universidad de Cádiz, por sua generosa acolhida, que proporcionou uma experiência enriquecedora durante o período de aprendizagem, propiciando as condições necessárias para o desenvolvimento deste estudo. À Cátedra RELEC da UCA, por ter propiciado oportunidade única de aprendizado e de experiência profissional, de valor incalculável para o desenvolvimento deste estudo, facilitando informações, contatos, visitas, assistência a eventos científicos formais, conferências, cursos, e outras atividades fundamentais para o tema investigado. Aos professores, funcionários, colegas da USP e da UCA e a todos os profissionais de instituições públicas e privadas, que colaboraram de alguma forma para esta pesquisa. A cada um em particular, por sua disponibilidade e sua importante contribuição. Não cito todos os nomes, pois a lista seria imensa e correria o risco de ficar incompleta. Mas, não posso deixar de agradecer de um modo especial a Vivian e David Gerritsen, Sonia e Peter Spring, João Victor Vega Longo, Leonardo Díaz Pineda, Jorge Rodríguez Almodóvar, Marcos Fernández González, Ramón Altadill Colominas, Estela M. Bonini, Enrique Gómez Rivas e Rodrigo Takano, por sua participação direta neste trabalho. Meu especial reconhecimento ao CNPq, cuja bolsa e taxa de bancada permitiram a realização desta pesquisa de doutorado com a profundidade necessária e à CAPES, por seu suporte econômico, com a concessão de bolsa do Programa de Doutorado com Estagio no ExteriorPDEE, para o período de estudo realizado na Espanha. A todos os amigos que encontrei em Cádiz e nos lugares que visitei, obrigada por me abrirem suas portas, sempre dispostos a ajudar. A meus filhos, à minha família e aos meus amigos de sempre, as palavras são poucas para agradecer. E, acima de tudo, à minha mãe, com muito carinho, muito obrigada por seu apoio incondicional e por me acompanhar em todos os momentos ao longo desta jornada. Este trabalho tambem é seu. Graças a Deus! 
Nunca ande pelo caminho traçado,

pois ele conduz somente até onde os outros chegaram.

Alexander Graham Bell

(1847 - 1922) 


\section{RESUMO}

REIDLER, N. M. V. L. Resíduos de equipamentos elétricos e eletrônicos em instituições de ensino superior: estudo de caso e diretrizes para a elaboração de um plano de gestão integrada. [Tese de doutorado]. São Paulo: Faculdade de Saúde Pública da USP; 2011.

Introdução: no Brasil, ainda não há legislação específica, em nível nacional, sobre resíduos de equipamentos elétricos e eletrônicos (REEE). Com a regulamentação da Política Nacional de Resíduos Sólidos, as instituições de ensino superior (IES) no país se deparam com a necessidade de criar sistemas de gestão integrada que incluam logística reversa e disposição desses equipamentos ao final de sua vida útil.

Objetivo: estudar a geração, fluxo e destino dos REEE de IES e propor diretrizes para a gestão institucional desses resíduos. Estudou-se o caso de duas IES, em dois cenários distintos: A) a Universidade de São Paulo (Brasil), sem influência de legislação específica sobre o tema e que não possui política de resíduos consolidada; B) A Universidade de Cádiz (Espanha), sob influência das Diretivas da União Europeia e de legislação nacional e que conta com política de resíduos e sistemas integrados de gestão de REEE.

Método: análise quali/quantitativa em ambas as IES que constou de: I) Diagnóstico da geração, fluxo e destino dos REEE. Técnica utilizada: levantamento dos dados censitários dos bens que sofreram processo de baixa em um período de dez anos, no sistema de informação da Administração Patrimonial; II) Criação de nova base de dados, com inclusão de classificação dos REEE por tipo, peso médio e periculosidade; III) Pesquisa participativa com os responsáveis por setores envolvidos com a gestão interna de REEE; e IV) Observação sistemática, com registros fotográficos e de dados obtidos, em locais de destino de REEE e em nove Sistemas de Gestão Integrada de REEE (SIG-REEE) da Espanha.

Resultados: o diagnóstico foi apresentado aos responsáveis por setores envolvidos com a gestão interna desses resíduos nas instituições, com objetivo de coletar sugestões para um plano de gestão de REEE que atendesse às suas necessidades e expectativas. Os resultados desta pesquisa levaram à proposta de diretrizes para a gestão institucional de REEE, orientando a execução das ações de controle de seus impactos econômicos, sociais, ambientais e de saúde de forma integrada e que seja sustentável e possa ser adaptado a quaisquer tipos de instituição, com flexibilidade para atender a diferentes necessidades e realidades.

Conclusão: I) Os procedimentos adotados atualmente nas IES estudadas não atendem aos requisitos fundamentais de sustentabilidade. II) Constatou-se que fatores internos determinam os caminhos da gestão externa do REEE. III) As diretrizes propostas para gestão integrada de REEE baseiam-se em três etapas principais: a) planejamento para aquisição do EEE; b) vida útil; c) gestão de REEE. O estudo conclui que para se conseguir um sistema de gestão sustentável e efetivo, é necessário considerar todas as etapas do ciclo de vida do produto, a partir do planejamento para sua aquisição, até seu destino final. Para que o sistema de gestão de REEE em IES seja efetivo, propõe-se a integração da gestão de EEE/REEE.

Palavras- chave: resíduos sólidos, logística reversa, fluxo de resíduos, sistema de gestão integrada de resíduos, resíduos de equipamentos elétricos e eletrônicos (REEE) em Instituições de Ensino Superior. 


\begin{abstract}
REIDLER, N. M. V. L. Electrical and electronic equipment waste in Higher Education Institutions: a case study and guidelines for the development of an integrated management plan [Doctoral Dissertation]. São Paulo: Universidade de São Paulo (USP) College of Public Health, 2011.

Introduction: in Brazil, there is no specific law at the national level for the disposal of electrical and electronic equipment waste (WEEE). With the National Solid Waste Policy regulations, Higher Education Institutions (HEI) in the country are faced with the need to create integrated management systems that include reverse logistics and disposal of such equipment at the end of its life time.

Objective: to study the generation, flow, and destination of WEEE from HEI and propose guidelines for developing an institutional management system for such waste. Two HEIs in two distinct scenarios were analyzed: A) the University of São Paulo (Brazil), which operates without the influence of legislation on the subject and does not have a consolidated waste policy; and B) The University of Cádiz (Spain), which operates under European Union Directives and national legislation, featuring an integrated waste management policy on WEEE.
\end{abstract}

Methods: qualitative/quantitative analyses in both institutions consisted of: I) Diagnosis of the generation, flow, and destination of WEEE based on census data on goods that have undergone a process of decline over a period of ten years in the Administração Patrimonial (Asset Management) information systems; II) Creation of a new database, which includes the classification of WEEE by type, average weight, and hazard risk; III) Research with the participation of the responsible parties of the sectors involved with the internal management of WEEE, and IV) Systematic observation, with photographic records and retrieved data from WEEE destinations and from nine Integrated Management Systems of WEEE (SIG-REEE) in Spain.

Results: the diagnoses were presented to the responsible parties of the sectors involved with the internal management of such waste in institutions, with the objective of gathering suggestions for a WEEE management system that meets needs and expectations. The results led to the proposal of guidelines for the preparation of an institutional WEEE management plan, to orient the implementation of sustainable practices in order to better control economic, social, environmental, and health impact in an integrated manner that is sustainable and can be adapted to any type of institution, with enough flexibility to meet different needs and realities.

Conclusion: I) the procedures currently in effect in HEI do not meet the core requirements of sustainability II) It was noted that internal factors determine the paths of external WEEE management. III) The guidelines proposed in this study for integrated management of WEEE were based on three main stages: a) acquisition of the EEE, b) useful life period; c) WEEE management. The study concludes that to achieve a sustainable and effective management system, it is necessary to consider all stages of the life cycle of a product, from planning to acquisition, to its final destination. The integration of EEE/WEEE management is recommended.

Keywords: solid waste, reverse logistics, waste flow management, integrated management system, electrical and electronic equipment waste (WEEE), electronic waste in Higher Education Institutions. 



\section{ÍNDICE}

1. INTRODUÇÃO 21

1.1 RESÍDUOS DE EQUIPAMENTOS ELÉTRICOS E

$\begin{array}{ll}1.2 \text { JUSTIFICATIVA DA PESQUISA } & 24\end{array}$

$\begin{array}{ll}1.3 \text { OBJETIVOS } & 25\end{array}$

1.3.1 Objetivo Geral 25

1.3.2 Objetivos Específicos $\quad 25$

2. MÉTODOS $\mathbf{2 6}$

2.1 FUNDAMENTAÇÃO TEÓRICA 26

$\begin{array}{ll}2.2 \text { ESTRATÉGIAS DE PESQUISA } & 27\end{array}$

2.2.1 Seleção das instituições para realização da pesquisa 27

2.2.2 Revisão bibliográfica $\quad 28$

2.2.3 Elaboração do diagnóstico $\quad 29$

2.3 ETAPAS METODOLÓGICAS 31

2.3.1 Desenho da pesquisa de campo $\quad 32$

2.3.2 Fontes de informação para elaboração do diagnóstico 32

2.3.3 Apresentação e discussão do diagnóstico 33

3. REVISÃO BIBLIOGRÁFICA

3.1 ANTECEDENTES HISTÓRICOS

3.2 TENDÊNCIAS DE GERAÇÃO DE REEE 38

3.3 OS REEE E SEUS IMPACTOS AMBIENTAIS, ECONÔMICOS SOCIAIS E À SAÚDE 40

3.4 GESTÃO SUSTENTÁVEL E INTEGRADA DE REEE 43

3.5 GESTÃO DE REEE EM INSTITUIÇÕES DE ENSINO 45

3.6 MARCO LEGAL NA UNIÃO EUROPEIA 49

3.6.1 Diretivas sobre Pilhas e Acumuladores 49

3.6.2 Lista Europeia de Resíduos $\quad 49$

3.6.3 Diretivas WEEE e RoHS 51

3.6.4 Definições segundo a Diretiva WEEE $\quad 52$

3.6.5 Transposição das Diretivas para as legislações nacionais 53

3.6.6 A experiência da aplicação das Diretivas WEEE e RoSH na

3.6.7 Revisão das Diretivas WEEE e RoSH

3.6.8 Revisão da Diretiva sobre Pilhas e Acumuladores $\quad 59$

3.7 MARCO LEGAL NA ESPANHA 60

3.7.1 Real Decreto sobre EEE e a gestão de seus resíduos 60

3.7.2 Real Decreto sobre pilhas e Acumuladores 61

3.7.3 Transposição das Diretivas da EU para a legislação
espanhola

3.7.4 A experiência da aplicação do RD 208/2005 na Espanha 63

3.7.5 Revisão do Real Decreto 208/2005 65

3.7.6 Revisão do Real Decreto sobre Pilhas e Acumuladores 66 
3.7.7 Sistemas Integrados de Gestão de REEE na Espanha 66

3.8 MARCO LEGAL NO BRASIL 67

3.8.1 Política Nacional de Resíduos Sólidos 67

3.8.2 A Política Nacional de Resíduos Sólidos e os REEE 69

3.8.3 Resolução CONAMA 401/2008 sobre pilhas e baterias 69

3.8.4 Descarte de lâmpadas fluorescentes $\quad 70$

3.8.5 Marco legal no Estado de São Paulo 71

3.8.6 Os REEE no Município de São Paulo 73

4. RESULTADOS E DISCUSSÃO

4.1 GERAÇÃO DE REEE NO CAMPUS QS/D DA USP 75

4.1.1 Distribuição do total de bens baixados do QS/D por unidade 76

4.1.2 Distribuição dos REEE baixados do QS/D por unidade 77

4.1.3 Evolução da geração de REEE no QS/D por ano 78

4.1.4 Distribuição da geração de REEE do QS/D por tipo de material 79

4.1.5 Classificação dos REEE baixados do QS/D segundo a periculosidade $\quad 80$

4.1.6 Classificação dos REEE baixados do QS/D por categorias WEEE (EU) $\quad 82$

4.1.7 Classificação dos REEE baixados do QS/D por categoria de cor

4.1.8 Classificação dos REEE baixados do QS/D $\begin{array}{ll}\text { por categoria de reciclagem } & 84\end{array}$

4.1.9 Estimativa do peso dos REEE baixados no QS/D por ano 87

4.1.10 Motivo da baixa dos bens $\quad 88$

4.2 CAMPUS QS/D USP - ANÁLISE QUALITATIVA

E INTERPRETAÇÃO DOS RESULTADOS 89

4.2.1 Investigação do destino dos REEE baixados do QS/D 90

4.2.2 Visitas às unidades que compõem o QS/Dq 91

4.2.3 Armazenamento do material inservível 95

4.2.4 Transporte dos REEE inservíveis do QS/D até o destino 101

4.2.5 Principais destinos de REEE do QS/D identificados 101

4.3 INVESTIGAÇÃO DO FLUXO E DESTINO DOS REEE 102

4.3.1 Visitas aos locais de destino dos REEE do QS/D 103

4.3.2 Procedimentos nos locais de recebimento dos REEE doados 104

4.3.3 Condições de trabalho nos locais de destino 107

$\begin{array}{ll}4.3 .4 \text { Capacitação } & 108\end{array}$

4.3.5 Outros destinos de REEE visitados 108

4.3.6 Fluxo dos REEE gerados no QS/D 115

4.4 APRENTAÇÃO DO DIAGNÓSTICO AOS ENVOLVIDOS

COM A QUESTÃO DOS REEE NO CAMPUS QS/D DA USP 116

4.5 IDENTIFICAÇÃO DE POTENCIAIS IMPACTOS DO FLUXO
DE REEE GERADOS NO CAMPUS QS/D DA USP

4.5.1 Impactos dos REEE saúde do trabalhador 118

4.5.2 Impactos dos REEE no ambiente 119

4.5.3 Impactos sociais e econômicos dos REEE 120 
4.5.4 Deficiências da gestão de REEE identificadas no Campus QS/D da USP

4.6 PESQUISA DE CAMPO NA UNIVERSIDADE DE CÁDIZ 123

4.6.1 Geração e caracterização dos REEE na UCA 124

4.6.2 Evolução da geração de REEE na uca por ano 124

4.6.3 Distribuição da geração de REEE da UCA por tipo de material 125

4.6.4 Classificação dos REEE baixados da UCA segundo a $\begin{array}{ll}\text { periculosidade } & 127\end{array}$

4.6.5 Classificação dos REEE baixados da UCA por categorias WEEE 128

4.6.6 Classificação dos REEE do ponto de vista de reciclagem 131

4.6.7 Classificação dos REEE baixados da UCA por categoria de limas de cor

4.6.8 Peso médio unitário e peso total 136

4.7 SISTEMA DE GESTÃO DE REEE NA UCA 138

4.7.1 Geração de REEE na UCA 140

4.7.2 Comparação entre os dados levantados no Sistema de Informação da Administração Patrimonial e os fornecidos pelo Serviço de Prevenção

4.7.6 Visita à planta de reciclagem RECILEC 149

4.8 SISTEMAS INTEGRADOS DE GESTÃO NA ESPANHA 153

4.9 COMPARAÇÃO ENTRE A GESTÃO DE REEE NA ESPANHA E NO BRASIL

4.9.1 Fluxos de REEE identificados no Brasil e na Espanha

5. DIRETRIZES PARA UM PLANO DE GESTÃO INTEGRADA DE REEE

5.2 INTEGRANDO O PROCESSO DE GESTÃO DE REEE EM IES 165

6. CONCLUSÕES E RECOMENDAÇÕES 171

7. REFERÊNCIAS 174

ANEXOS

Anexo 1 - Conceitos de Administração Patrimonial - USP 201

Anexo 2 - Manual de Procesos del Área de Economia (Version 1.1.) 205

APÊNDICES

Apêndice 1 - Roteiro para Orientação dos Grupos de Trabalho no Workshop para Apresentação do Diagnóstico

Apêndice 2 - Check List para Avaliação dos Locais de Destino 207

Apêndice 3 - Roteiro Estruturado de Visita Técnica aos Locais de Destino de REEE 208

Apêndice 4 - Algumas Empresas Registradas Oficialmente como Recicladoras de REEE no Brasil 


\section{LISTA DE FIGURAS}

Figura 1 - Desenho da pesquisa de campo 32

Figura 2 - Material baixado à espera de coleta sob uma pia, em unidade do QS/D

Figura 3 - Material baixado e sucata à espera de coleta, sem proteção, em corredor de unidade do QS/D

Figura 4 - Depósito protegido de equipamentos de ar condicionado baixados do patrimônio de uma unidade do QS/D

Figura 5 - Armazenamento temporário de REEE não patrimoniado no QS/D

Figura 6 - Estrutura básica da Faculdade de Medicina (FM)

Figura 7 - REEE perigoso (baterias de chumbo) junto com material reciclável a ser doado para cooperativa de catadores, em unidade do QS/D

Figura 8 - Depósito de material baixado em uma unidade do QS/D, à espera de ser doado

Figura 9 - Armazenamento de lâmpadas ao ar livre, sem proteção e junto com outros resíduos em unidade do QS/D

Figura 10 - Armazenamento temporário de bens inservíveis para doação, em unidade do QS/D

Figura 11 - Armazenamento temporário de sucata em unidade do QS/D da USP

Figura 12 - Transporte de sucata do QS/D

Figura 13 - Armazenamento de sucata doada na FUSSESP

Figura 14 - Armazenamento temporário de lotes de sucata doada para leilão na FUSSESP

Figura 15 - Armazenamento temporário de REEE de refrigeração em lotes, para leilão na FUSSESP

Figura 16 - Carregamento de lotes de sucata e REEE contendo gases de refrigeração, preparados para transporte

Figura 17 - Transporte de sucata de REEE de refrigeração contendo espuma de poliuretano, impregnada com CFC

Figura 18 - Armazenamento temporário de REEE em local aberto na FUSSESP

Figura 19 - Armazenamento temporário de REEE doado, na FUSSESP 108

$\begin{array}{ll}\text { Figura } 20 \text { - Etapas de operação do projeto CEDIR } & 109\end{array}$

Figura 21 - Prensa de REEE no CEDIR 110

Figura 22 - Armazenamento incorreto de monitores no CEDIR 110

Figura 23 - Balança para pesagem dos REEE no CEDIR 110

Figura 24 - COOPERMITI - Cooperativa de Reciclagem de REEE 112

Figura 25 - Principais fluxos identificados de REEE gerados no QS/D 115

Figura 26 - Luminárias para tubos fluorescentes retos 132

Figura 27 - Luminárias para exteriores 132 
Figura 28 - Detalhe de luminária para exteriores $\quad 132$

Figura 29 - Alguns tipos de equipamentos de iluminação 133

$\begin{array}{ll}\text { Figura } 30 \text { - Alguns tipos de lâmpadas que devem ser recicladas } & 133\end{array}$

Figura 31 - Coletor de pilhas do Serviço de Prevenção 138

Figura 32 - Coletor de pilhas, cartuchos e toners da Oficina Verde da Gerência Administrativa

Figura 33 - Coletor de pilhas, cartuchos e toners da Oficina Verde (detalhe)

Figura 34 - Ponto de Coleta Seletiva da Gerência Administrativa, com coletores para pilhas, cartuchos e outros resíduos

Figura 35 - Transporte de REEE misturados com outros tipos de resíduos em caminhão de mudanças

Figura 36 - Transporte de REEE misturados com resíduos volumosos

Figura 37 - REEE carregados em caçamba de empresa de remoção de entulhos para enviar a aterros

Figura 38 - Centro de transferência de resíduos da UCA no Campus de Puerto Real

Figura 39 - Campanha de Coleta Seletiva de REEE da RELEC, no saguão de entrada principal da UCA, no Campus de Puerto Real

Figura 40 - Coletor de pequenos REEE na parte externa do edifício principal do Campus de Puerto Real, ao lado da Cafeteria $\quad 146$

Figura 41 - REEE abandonado no corredor

Figura 42 - REEE perigoso, armazenado em área de trânsito 147

Figura 43 - Linha de classificação de REEE na RECILEC 151

Figura 44 - Linha de tratamento de lâmpadas fluorescentes RECILEC 152

Figura 45 - Reciclagem de monitores TRC na RECILEC 152

Figura 46 - Uso obrigatório de EPIs em todas as etapas de tratamento e reciclagem de REEE na RECILEC 153

Figura 47 - Dois tipos de coletores de pilhas 156

Figura 48 - Dois tipos de coletores de lâmpadas 156

$\begin{array}{ll}\text { Figura } 49 \text { - Coletor de celulares } & 157\end{array}$

$\begin{array}{ll}\text { Figura } 50 \text { - Coletor de pequenos REEE } & 157\end{array}$

\section{LISTA DE QUADROS}

Quadro 1 - Classificação dos REEE na Lista Europeia de Resíduos (LER) 50

Quadro 2 - Categorias de REEE incluídas e excluídas na CE7042/11 58

Quadro 3 - Metas diferenciadas de coleta, reciclagem e tratamento específicos para cada categoria de tratamento de REEE $\quad 59$

Quadro 4 - Resumo da transposição das Diretrizes WEEE e RoSH para a legislação nacional $\quad 62$

Quadro 5 - Classificação dos REEE segundo a categoria de reciclagem 85 
Quadro 6 - Resumo dos resultados obtidos nas visitas às unidades do QS/D

Quadro 7 - Resumo das atividades nas plantas de reciclagem visitadas e seus potenciais impactos na saúde do trabalhador

Quadro 8 - Deficiências na gestão de REEE identificadas no Campus QS/D da USP

Quadro 9 - Comparativo dos REEE baixados no Campus QS/D da USP e na UCA, em \% por categoria WEEE, em um período de 10 anos

Quadro 10 - Resumo dos principais SIG em funcionamento na Espanha 158

Quadro 11 - Gestão de REEE USP X UCA

Quadro 12 - Comparativo entre os pontos fortes e os pontos fracos da USP e da UCA

Quadro 13 - Comparativo entre os fluxos de REEE gerados na USP e na UCA 162

Quadro 14 - Diretrizes para a gestão integrada de EEE/REEE em IES

\section{LISTA DE GRÁFICOS}

Gráfico 1 - Participação percentual de bens baixados por unidade do QS/D (\%) (1999 - 2009)

Gráfico 2 - Participação percentual de REEE baixado por unidade de QS/D (\%) (1999 - 2009)

Gráfico 3 - Distribuição percentual de REEE baixados do QS/D por ano (\%) (1999 - 2009)

Gráfico 4 - Participação percentual de REEE baixados do QS/D por tipo de material (\%) (1999-2009)

Gráfico 5 - Participação percentual de REEE por periculosidade (\%), baixados do QS/D (1999 - 2009)

Gráfico 6 - Participação percentual de REEE baixados por categoria de cor $(\%)(1999-2009)$

Gráfico 7 - Participação de REEE baixados do QS/D por categoria de reciclagem (\%) (1999 - 2009)

Gráfico 8 - Participação percentual de REEE baixados da UCA por ano (\%) (2000-2010)

Gráfico 9 - Comparativo entre a evolução da geração anual de REEE na UCA e na USP

Gráfico 10 - Distribuição percentual de REEE baixados da UCA por tipo de material (grupos) $(2000$ - 2010)

Gráfico 11 - Participação percentual de REEE baixados da UCA por periculosidade $(2000-2010)$

Gráfico 12 - Distribuição percentual de REEE baixados da UCA por categoria WEEE (UE) $(2000$ - 2010)

Gráfico 13 - Comparativo da distribuição percentual de REEE baixados do patrimônio da UCA e do Campus QS/D da USP por categoria WEEE (UE), no período de dez anos 
Gráfico 14 - Participação percentual de REEE baixados da UCA por categoria de reciclagem (\%) $(2000-2010)$

Gráfico 15 - Comparativo entre a distribuição percentual de REEE baixados, por categoria de reciclagem na UCA e no Campus QS/D da USP, no período de dez anos

Gráfico 16 - Participação percentual de REEE baixados da UCA por categoria cor $(\%)(2000-2010)$

\section{LISTA DE TABELAS}

Tabela 1 - Indicadores numéricos USP - QS/D, em 2010

Tabela 2 - Comparativa entre a participação percentual do total de bens baixados e a participação percentual do total de REEE por unidade do QS/D (1999 - 2009)

Tabela 3 - Distribuição de REEE baixados do QS/D (1999 - 2009) por grupos de material

Tabela 4 - Distribuição de REEE baixados do QS/D por categoria WEEE (UE) (1999 - 2009)

Tabela 5 - Distribuição dos REEE baixados do QS/D por categoria de cor (1999 - 2009)

Tabela 6 - Distribuição dos REEE baixados do QS/D por categoria operacional (1999 - 2009)

Tabela 7 - Estimativa do peso total de REEE baixados do QS/D por unidade/ano (1999 - 2009)

Tabela 8 - Distribuição dos motivos de baixa dos REEE dos QS/D (1999 - 2009)

Tabela 9 - Comparativa entre os EEE baixados nos Sistema MERCURIO e os REEE não patrimoniados registrados pelo Departamento de Gestão Ambiental da FMUSP (1999 - 2009)

Tabela 10 - Comparativa da participação percentual de periculosidade dos REEE baixados na UCA e no Campus QSD/USP em um período de dez anos

Tabela 11 - Distribuição dos REEE baixados da UCA por categoria operacional no período $(2000-2010)$

Tabela 12 - Distribuição dos REEE baixados da UCA por categoria de cor $(2000$ - 2010)

Tabela 13 - Estatística descritiva dos pesos médios anuais dos REEE gerados na UCA $(2000-2010)$

Tabela 14 - REEE gerenciados pelo Serviço de Prevenção da UCA (2006 - 2010)

Tabela 15 - Comparativa entre os pesos médios anuais de REEE da UCA 


\section{SIGLAS UTILIZADAS}

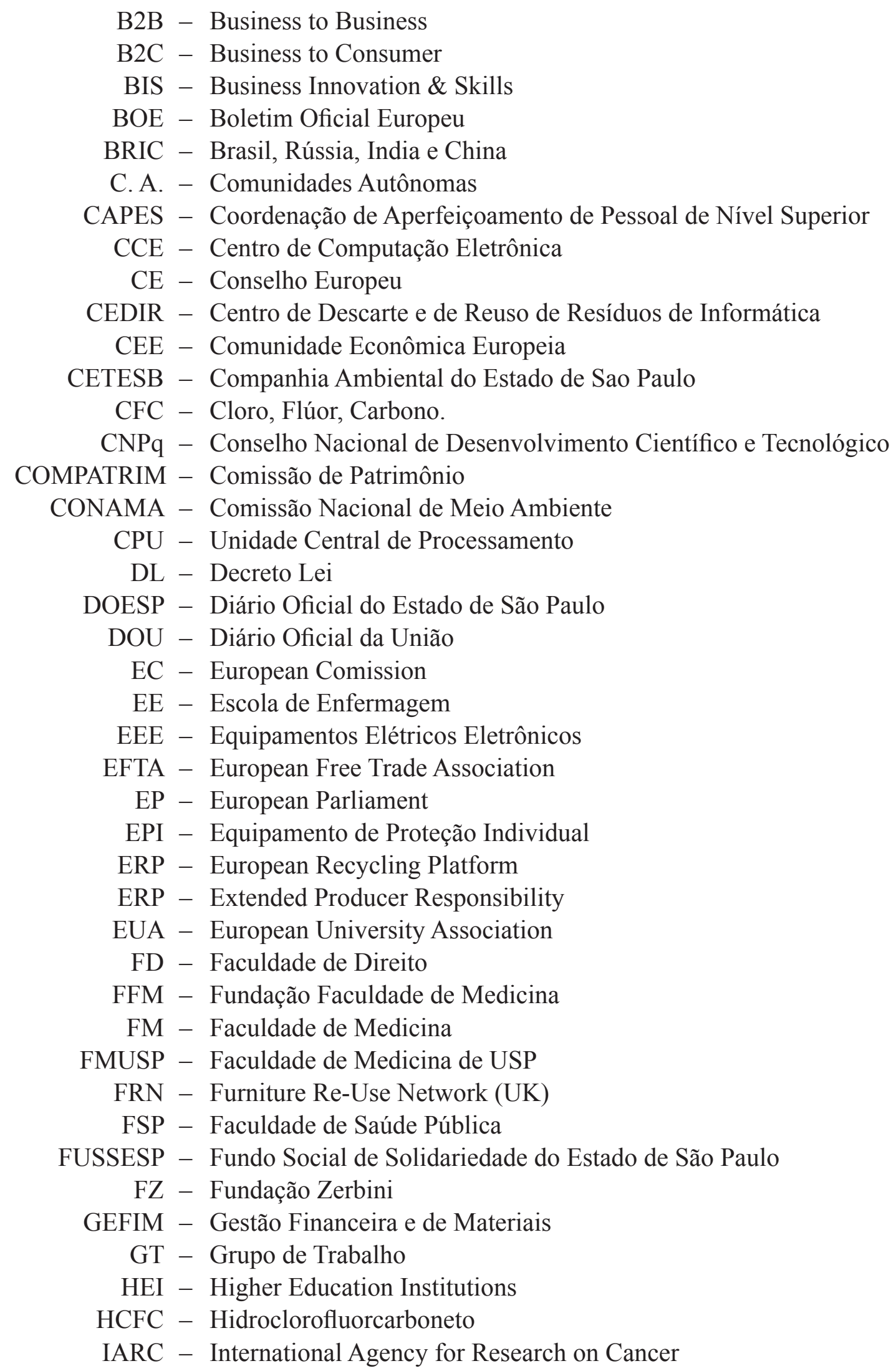


IBAMA - Instituto Brasileiro do Meio Ambiente e dos Recursos Naturais Renováveis

IES - Instituição de Ensino Superior

IMT - Faculdade de Medicina Tropical

ISO - International Standard Organization

LCD - Liquid Crystal Display

LER - Lista Europeia de Resíduos

LIMPURB - Departamento de Limpeza Urbana da Prefeitura de São Paulo

LIMs - Laboratórios de Investigação Médica

MARM - Ministério do Meio-Ambiente, Meio Rural e Marinho da Espanha

MMA - Ministério do Meio Ambiente

NCM - Nordic Council of Ministres

OCDE - Organização para a Cooperação e o Desenvolvimento Econômico

OCU - Organización de Consumidores y Usuarios (Espanha)

OECD - Organisation for Economic Co-operation and Development.

OMS - Organização Mundial de Saúde

ONG - Organização não Governamental

OPS - Organização Panamericana de Saúde

PCB - Bifenila policlorada

PCPs - Poluentes policloradas não aromatizados

PE - Parlamento Europeu

PGREEE - Plano de Gestão de REEE

PGIREEE - Plano de Gestão Integrada de REEE

PERS - Política Estadual de Residuos Sólidos

PEV - Posto de Entrega Voluntária

PL - Projeto de Lei

PNRS - Política Nacional de Resíduos Sólidos

POP - Poluente Orgânico Persistente

PPRA - Programa de Prevenção de Riscos Ambientais

QS/D - Quadrilátero de Saúde/Direito

RD - Real Decreto

REEE - Resíduos de Equipamentos Elétricos e Eletrônicos

REI - Registro de Estabelecimentos Industriais

REP - Responsabilidade estendida do produtor

RFID - Radio Frequency Identification

RIP - Responsabilidade individual do Produtor RoHS

RoHS - Restriction of Hazardous Substances in Electrical and Equipments

SABESP - Companhia de Saneamento Básico do Estado de São Paulo

SESA - Serviço Especial de Saúde de Araraquara

SGA - Sistema de Gestão Ambiental

SIAP - Sistema de Informação de Administração Patrimonial

SICOC - Sistema de Informação de Baixa de Bens Patrimoniais da UCA

SIG - Sistemas Integrados de Gestão

SGIREEE - Sistema de Gestão Integrada de REEE

SMA - Secretaria de Meio Ambiente 


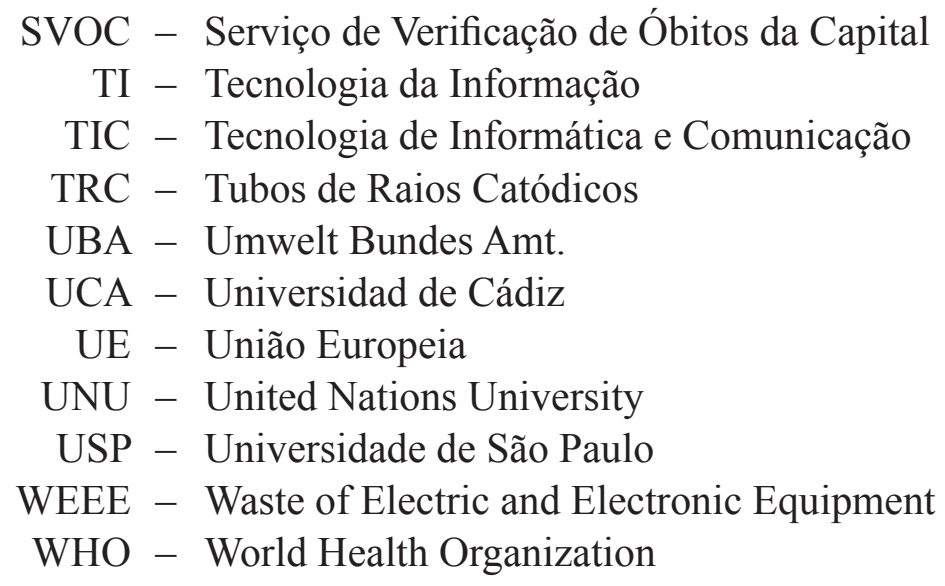






\section{INTRODUÇÃO}

A produção de equipamentos elétricos e eletrônicos (EEE) é hoje uma das atividades que mais crescem em termos globais. Os avanços tecnológicos, com o surgimento constante de produtos cada vez mais sofisticados, geram uma demanda cada vez maior por acessórios, periféricos, componentes e novas tecnologias, impulsionando o consumo, a produtividade e a economia, em um moto contínuo. A obsolescência programada para uma vida útil cada vez mais curta leva o consumidor a descartar seus equipamentos em tempo cada vez menor, resultando na produção de resíduos de equipamentos elétricos e eletrônicos (REEE) cada vez mais acelerada. A popularização das tecnologias sem fio e a queda dos custos dos EEE viabilizam o acesso em massa a esses produtos e deixam o mundo cada vez menor, não só por tornar as distâncias irrelevantes para a comunicação, como por falta de espaço para abrigar a imensa quantidade de resíduos gerada pelo setor.

A gestão de REEE apresenta complexidade maior do que a de outros tipos de resíduos, em função de seu volume, de sua grande diversidade e de suas características de periculosidade, envolvendo grande número de componentes e elementos químicos, além da insuficiência de experiência acumulada nessa área, para acompanhar as necessidades de inovação na solução dos novos problemas surgidos a cada dia. Como consequência, são incontáveis os projetos, pesquisas, normativas e tentativas em muitos países, desenvolvidos com o objetivo de definir uma gestão ainda mais eficiente que a atualmente contemplada nas legislações mais avançadas, como as dos países da União Europeia (UE). Exemplo disso é o intenso trabalho de revisão das atuais Diretivas WEEE e RoHS (PARLAMENTO EUROPEU, 2002), iniciado em 2008 (EC, 2008).

Há mais de duas décadas que a gestão de REEE tem sido motivo de atenção e de preocupação em países da Europa, América do Norte e Ásia. O grande volume e diversidade de EEE descartados, as substâncias valiosas, recicláveis e de natureza não renovável, as substâncias perigosas que podem ser liberadas no ambiente por manejo inadequado, as reações químicas, sinergias e potencializações que podem ocorrer em condições adversas, requerem criação de políticas públicas e legislação sobre o tema. 
Alguns países do continente europeu, como a Alemanha, Bélgica, Suécia e Suíça entre outros, são considerados referências para o tema de REEE, onde esses resíduos passaram a ser considerados prioritários desde 1991. Enquanto a União Europeia (UE) se encontra em um período de maturação, com a revisão da legislação para corrigir problemas identificados nas Diretivas WEEE e RoHS (PARLAMENTO EUROPEU, 2002) e buscar soluções para problemas surgidos após sua publicação, o Brasil encontra-se no início da aprendizagem. Apesar de o tema já ser discutido no país há algum tempo e legislações estaduais e municipais específicas terem sido criadas, não há política ou legislação específica em nível nacional e apenas em agosto de 2010 foi aprovada a Lei Federal No 12.305, que institui a Política Nacional de Resíduos Sólidos (BRASIL, 2010), na qual o fluxo dos REEE é prioritário.

O Brasil, considerado como uma das potências emergentes em âmbito global, com economia estável e consumo interno em expansão, é um dos grandes geradores atuais de REEE. Embora não haja no país marco regulatório específico para a questão, a aprovação da Política Nacional de Resíduos Sólidos (PNRS) impõe a busca de alternativas de gestão e de recuperação desses resíduos, estabelecendo a obrigatoriedade da Logística Reversa para esses produtos, após o término da sua vida útil.

\subsection{RESÍDUOS DE EQUIPAMENTOS ELÉTRICOS E ELETRÔNICOS NO CONTEXTO INSTITUCIONAL}

Em relação à origem, os REEE podem ser classificados em domiciliares ou institucionais. Essa divisão é determinante para definir o modelo de gestão a ser adotado em cada caso. Enquanto a gestão dos REEE de origem domiciliar é de responsabilidade da Administração Pública e exige sistemas complexos de logística reversa e de controle, a gestão dos REEE de origem institucional, que têm geração pontual, teoricamente, é mais simples e poderia ser facilitada por seu sistema de informação gerencial, se adequado para esse fim (REIDLER, 2010).

De origem difusa, os REEE domiciliares têm geração e destino difíceis de serem estimados. No Brasil, faltam muitas informações básicas e não há estimativa confiável 
de geração e destino dos REEE. Em geral, os dados sobre os REEE domiciliares são escassos, dispersos e desatualizados. Há exceções importantes, como o caso de Belo Horizonte (MG), por exemplo, onde foi realizado um diagnóstico da situação desses resíduos no município, estimando sua geração e fluxo (FRANCO e LANGE, 2011) e no Estado de Minas Gerais (FEAM, 2009). Os resultados mostraram que a principal destinação dada pelos consumidores particulares para o descarte de seus REEE é a doação. Geralmente, as ações de gerenciamento ambientalmente corretas são oriundas da iniciativa privada e aplicadas apenas a equipamentos de informática e telefonia móvel. Os demais REEE estão sendo manipulados sem as devidas precauções de saúde e segurança do trabalhador, bem como dispostos de forma irregular.

No âmbito institucional, as grandes organizações têm buscado soluções que contemplem a minimização de resíduos, do consumo de energia e do uso de recursos naturais. Embora as novas tendências mundiais de gestão de resíduos apontem para o consumo responsável, a prevenção e a reutilização como prioridades (PARLAMENTO EUROPEO Y DEL CONSEJO, 2008), no caso dos REEE a reciclagem ainda se apresenta como alternativa principal para eliminar a ameaça concreta que esses resíduos representam ao meio ambiente (DIAS, 2008).

Cada vez mais o conceito de gestão ambiental vem sendo ampliado para incluir programas desenvolvidos por empresas e instituições de todos os tipos, de modo a administrar as suas atividades dentro dos modernos princípios de proteção do meio ambiente. A literatura sobre economia da inovação, administração organizacional e gestão ambiental tem salientado ao longo da última década a importância dos Sistemas Integrados de Gestão e várias têm sido as tentativas de reproduzir essa experiência, nos mais variados ambientes e setores (RIGAMONTI; GROSSO e GIUGLIANO, 2009).

As Instituições de Ensino Superior (IES) destacam-se por sua expansão em nível mundial, contribuindo com crescente aumento da produção global de REEE, em função da constante demanda por novas tecnologias. Estudo realizado na Universidade de Arizona, nos Estados Unidos mostrou que a vida útil dos EEE tem diminuido ao longo do tempo, especialmente no caso dos equipamentos de tecnologia de informação (TI) (BABBIT, 2009). Essas instituições enfrentam desafios dos mais variados tipos, associados a questões legislativas, pressões econômicas e ambientais e outros, por vezes difíceis de controlar e de gerenciar (ZHANG e col, 2011). Além de Universidades de 
países desenvolvidos, consideradas como referência para o tema em estudo, IES de países emergentes, como o Brasil, Rússia India e China (BRIC) e de países em desenvolvimento, em todos os continentes, têm buscado soluções sustentáveis para seus REEE (WIDMER, 2005).

Considerando-se a crescente geração dos REEE em IES, a sua composição cada vez mais complexa e a falta de conhecimento sobre sua destinação, o diagnóstico de geração e fluxo desses produtos pós-consumo é fundamental para o desenvolvimento de um plano de gestão que integre as iniciativas bem sucedidas já existentes e experiências acumuladas dentro das instituições e atenda às exigências legais determinadas pela PNRS. Nesta pesquisa estudou-se o caso de duas IES, a Universidade de São Paulo (USP) e a Universidad de Cádiz (UCA), envolvendo as seguintes as hipóteses:

a) Embora exista nas instituições a preocupação com a questão legal dos REEE e com a sua gestão interna, os procedimentos de descarte e as alternativas de destino adotadas após o procedimento de baixa patrimonial não estão atendendo aos requisitos de sustentabilidade do ponto de vista ambiental, social e de saúde.

b) Além da legislação específica sobre o tema, fatores internos à instituição exercem influência sobre a gestão externa de REEE gerados nas IES.

\subsection{JUSTIFICATIVA DA PESQUISA}

A seleção das instituições para a realização desta pesquisa fundamenta-se na importância dessas como agentes de mudança. As grandes organizações são compradoras de tecnologia e têm poder de negociação, com possibilidade de considerar além dos aspectos econômicos, outros aspectos fundamentais de sustentabilidade, no momento de decidir pela adoção de produtos e de serviços. As IES desempenham papel importante na sociedade, como exemplo e fonte de conhecimento. Essas instituições são locais-chave de aprendizagem e de pesquisa, produtoras de conhecimento, grandes geradoras de emprego, agentes econômicos e fornecedoras de recursos culturais, recreativos e de infraestrutura (LAMBERT, 2003), com um considerável potencial para catalisar e acelerar transições sociais para a sustentabilidade (STEPHENS et al., 2008). É reconhecida a sua responsabilidade no ensino de tecnologias, sistemas e filosofias que 
permitam o desenvolvimento das competências e capacidades dos futuros profissionais da nossa sociedade, preparando-os para os novos desafios (VEGA, BENITEZ e BARRETO, 2003).

Embora muitas IES brasileiras possuam programas de gestão de resíduos como parte integrante de sua gestão ambiental, a questão dos REEE é tratada ainda de maneira muito superficial, como um tipo de resíduo sólido a mais a ser gerenciado. Essa visão pode persistir em função da pouca vivência sobre o tema na prática, como resultado de sua constante evolução, além da carência de infraestrutura para encaminhamento desses resíduos. Pode-se dizer que a gestão de REEE é um processo dinâmico, diferentemente de outros resíduos, cujo problema já está equacionado.

\subsection{OBJETIVOS}

\subsubsection{Objetivo Geral}

Compreender a gestão dos REEE realizada atualmente em duas IES, em âmbito nacional e internacional, com o objetivo de formular diretrizes para a elaboração de um sistema de gestão de REEE para esse tipo de instituição, orientado para a execução das ações de controle de seus impactos econômicos, sociais, ambientais e de saúde de forma integrada. Pretende-se que essas diretrizes possam servir de orientação para qualquer tipo de instituição, pública ou privada, com flexibilidade para atender as suas diferentes necessidades e realidades.

\subsubsection{Objetivos Específicos}

- Realizar levantamento de geração e fluxo dos REEE nas IES selecionadas, para obtenção de diagnóstico da situação dos REEE no âmbito das unidades investigadas.

- Identificar potenciais impactos decorrentes do fluxo dos REEE institucionais, considerando aspectos socioeconômicos, ambientais e de saúde.

- Identificar possíveis fatores de influência sobre a gestão de REEE em instituições, com o objetivo de nortear a formulação das diretrizes propostas. 


\section{MÉTODOS}

\subsection{FUNDAMENTAÇÃO TEÓRICA}

Segundo YIN (2001), o estudo de caso é uma estratégia a ser utilizada quando o foco da pesquisa se encontra em fenômenos contemporâneos inseridos em algum contexto da vida real, para se preservar as características holísticas e significativas dos eventos estudados.

Esta é uma pesquisa exploratória, com o objetivo de proporcionar maior familiaridade com o tema da gestão de REEE em IES e é descritiva, pois envolve a observação sistemática dos fatos, que são registrados, analisados, classificados e interpretados, sem interferência da pesquisadora (ANDRADE, 2003). Apresenta os acontecimentos da forma como sucederam, enfatizando palavras e imagens, por meio de entrevistas informais e registros fotográficos.

Esta pesquisa consiste em estudo de caso instrumental (VENTURA, 2007), que examina o caso de duas IES, cada uma em um contexto distinto, para se compreender melhor quais os fatores de influência na geração, fluxo e destino dos REEE institucionais. Trata-se de estudo de caso coletivo, pois estende o estudo a outros casos instrumentais conexos com o objetivo de ampliar a compreensão e a teorização sobre um conjunto maior de casos (VENTURA, 2007).

O estudo é transversal, com horizonte temporal definido de dez anos, compreendido no período entre 1999 e 2009 no caso da USP e, entre 2000 e 2010 no caso da UCA. Abrange o levantamento da geração dos REEE em unidades de duas IES, a Universidade de São Paulo (USP) e a Universidade de Cádiz (UCA) e a observação sistemática de seu gerenciamento interno e do fluxo externo até seu destino. Utilizam-se abordagens quantitativas e qualitativas de pesquisa. 


\subsection{ESTRATÉGIAS DE PESQUISA}

Para buscar respostas às questões investigadas e conhecer o funcionamento da gestão de REEE institucional na prática, estudou-se a situação dos REEE em duas Instituições de Ensino Superior - IES, com cenários distintos: com e sem influência de uma legislação específica que regulamente o tema. O foco principal desta pesquisa concentra-se na gestão de REEE, nas unidades do Campus QS/D da USP.

A opção pela Espanha para realizar parte da pesquisa deve-se ao fato de este ser um país europeu que apresenta considerável semelhança cultural com o Brasil, que está inserido na política ambiental da União Europeia e segue as diretivas para a gestão dos resíduos sólidos e as diretivas específicas para a gestão dos REEE. A Espanha já possui diversos Sistemas Integrados de Gestão (SIG) de REEE em operação, atuando em âmbito nacional, segundo as determinações da Diretiva WEEE (UE, Directiva 2002/96/CE), o que propicia uma avaliação de seu funcionamento e para identificação de pontos positivos e negativos da gestão de REEE implementadada.

\subsubsection{Seleção das instituições para realização da pesquisa}

A Universidade de São Paulo (USP) é a única representante latino-americana no ranking das 200 melhores no Times Higher Education (EXAME, 2012) e, apesar de possuir um programa de reciclagem de resíduos - o USP RECICLA - desde 1994, ainda não possui plano institucional de gestão para seus REEE. Em estudos preliminares, foram identificadas ações isoladas de gerenciamento nesse sentido. Porém, essa prática individualizada de gerenciamento mostra-se limitada, em função da carência de dados técnicos relativos à geração, composição e operacionalização do gerenciamento. Para solucionar esse problema, propõe-se um sistema integrado de gestão desses resíduos na Instituição. A USP conta com sete Campi e duas Coordenadorias distribuídas no estado de São Paulo, com um número total de 88.962 alunos matriculados (USP, 2010). Em

função de seu tamanho, decidiu-se realizar o estudo em uma amostra intencional, composta pelas unidades da Coordenadoria do Quadrilátero Saúde/Direito da USP.

A Coordenadoria do Quadrilátero Saúde/Direito, situada no município de São Paulo (QS/D) da USP foi criada em dezembro de 2008 (USP (a); (b); (c), 2008), com 
objetivo de descentralizar atividades do Órgão Central da instituição, a fim de promover maior eficiência e agilidade em sua gestão. A aposta em uma gestão ambiental moderna, na qual a questão dos REEE está entre as suas prioridades motivou esta pesquisa e determinou a delimitação do estudo ao âmbito de suas cinco unidades: Escola de Enfermagem (EE), Faculdade de Direito (FD), Faculdade de Medicina (FM), Faculdade de Saúde Pública (FSP) e Instituto de Medicina Tropical (IMT). Em 2009, o número de alunos matriculados no QS/D da USP era de 9.105 alunos.

A escolha da Universidad de Cádiz (UCA) para a realização de parte desta pesquisa fundamenta-se na oportunidade de cooperação oferecida por seu Departamento de Tecnologia Ambiental, através da Cátedra RELEC de Electrónica/ Comunicaciones y Sostenibilidad, também da UCA. A RELEC é fruto da colaboração entre os Círculos de Innovación y Tecnología de la UCA e organizações do setor de EEE, com atividades em reciclagem, reutilização e gestão final de REEE. Agrega praticamente a totalidade dos integrantes dos setores de eletrônica, comunicações e reciclagem de REEE na Espanha (CATEDRA RELEC, 2011). A diversidade de suas atividades, a qualificação e os diferentes pontos de vista de seus integrantes com relação à questão dos REEE, além da experiência e do conhecimento adquirido por seus pesquisadores e organizações associadas foram consideradas relevantes para esta pesquisa e motivaram essa decisão. A Universidade de Cádiz (UCA) é uma IES pública, membro da Asociación Europea de Universidades (EUA). A UCA está localizada em Andaluzia, uma das dezessete comunidades autônomas da Espanha. Atualmente a Universidade de Cádiz conta com quase 22.000 alunos, distribuídos por cinco campi, localizados nas cidades de Cádiz (dois), Puerto Real, Jerez de La Frontera e Algeciras (UCA, 2011). Em função de seu tamanho reduzido decidiu-se realizar a investigação em todos os campi da universidade, considerando todas as unidades da instituição.

\subsubsection{Revisão bibliográfica}

$\mathrm{Na}$ revisão bibliográfica, realizou-se um aprofundamento conceitual e do marco legal regulatório, voltado para a questão dos REEE em suas diferentes interfaces, considerando os pilares da sustentabilidade e com foco na gestão dos REEE. 


\subsubsection{Elaboração do diagnóstico}

Antes do início da pesquisa experimental, foi solicitada às instituições investigadas, respectivamente a Coordenadoria do Quadrilátero Saúde/Direito da USP (QS/D) e a Vice-Reitoria de Infraestrutura da Universidade de Cádiz (UCA), autorização para a realização de levantamento de dados nos respectivos Sistemas de Informação de Administração Patrimonial, nas unidades que as compõem e junto aos setores de Materiais, Controladoria, Informática e outros que se fizessem necessários. Ao Setor de Administração Patrimonial compete a incorporação e o gerenciamento de bens de uma instituição, que termina com os procedimentos de baixa.

Entende-se por baixa patrimonial, "o procedimento de exclusão de bens do ativo permanente da Universidade, segundo as normas estabelecidas...” (USP, 2004; UCA, 2006). Alguns conceitos são fundamentais para entender o processo de administração patrimonial das IES. Os mais importantes para esta pesquisa, com base no Manual de Administração Patrimonial da USP, estão resumidos no ANEXO I (GEFIM, 2004; USP, 2010). (UCA, 2006). Um resumo dos procedimentos da Administração Patrimonial da UCA é apresentado no ANEXO II.

O inventário patrimonial consiste no cadastro físico de bens permanentes ou duráveis e reúne uma série de informações importantes. Utilizou-se a metodologia de análise de dados censitários, que estuda um universo mediante a enumeração de todas as suas unidades (USP, 2010). Para estimar e caracterizar a geração de REEE recorreu-se ao levantamento de bens patrimoniais, após sua baixa nos sistemas de informação da Administração Patrimonial das IES selecionadas. Na USP, o levantamento de dados no SIAP (SISTEMA MERCÚRIO) foi realizado para a localização do registro de todos os bens patrimoniais das unidades do QSD/USP baixados no período de 1999 a 2009. Esse material inclui as dez categorias da Diretiva WEEE 2002/96/CE e sua revisão (CE, 2008), que integra as Diretivas WEEE (2002/96/CE), RoHS (2002/95/CE) e 2006/66/CE (pilhas e acumuladores), considerados nesta pesquisa. Na UCA, a mesma metodologia foi utilizada para o levantamento em seu sistema de informação da administração patrimonial (SICOC), que compreendeu o período entre 2000 e 2010. A base de dados global do Sistema de Informação Gerencial é complexa e contem muitas informações sem interesse para esta pesquisa. Dos registros do sistema, foram selecionados apenas os dados referentes à origem dos bens, sua descrição e data de baixa. 
Para GIL (2008), entre as principais vantagens do levantamento estão o conhecimento direto da realidade e a possibilidade de quantificação. Por outro lado, este apresenta algumas limitações no que se refere ao estudo das relações sociais mais amplas, sobretudo quando estas envolvem variáveis de natureza institucional. No presente estudo, o método quantitativo foi utilizado para: a) caracterizar os tipos de REEE institucionais; b) conhecer a frequência dos REEE por categorias, nas IES investigadas; c) conhecer a evolução anual da geração de REEE em cada IES investigada; d) estimar o volume em peso/ ano dos REEE gerados na instituição.

A análise quantitativa dos dados obtidos nesta etapa foi complementada com uma pesquisa documental, para investigar o destino dos REEE gerados em ambas as universidades, após os procedimentos de baixa patrimonial. Na USP essa pesquisa foi realizada nos processos de baixa patrimonial, junto ao Setor de Patrimônio de cada unidade pesquisada, responsável pela destinação dos bens inservíveis. Na UCA, os dados estatísticos extraídos do SICOC foram complementados com a pesquisa documental realizada junto ao Setor de Prevenção, responsável pela destinação de resíduos perigosos, que incluem os REEE. Esses dados proporcionaram melhor visão do problema e foram fundamentais como ponto de partida para investigar o fluxo desses resíduos em estudo de campo, com abordagem qualitativa.

De acordo com ALVES-MAZZOTTI e GEWANSZNAJDER (2001), a pesquisa qualitativa exige que os fenômenos sociais sejam vistos em sua totalidade e que o foco e o delineamento do estudo sejam baseados no conhecimento que o pesquisador possui acerca da realidade a ser pesquisada e na influência que as pessoas daquele grupo exercem umas sobre as outras. No presente caso, utilizou-se como fonte de dados o ambiente natural (TEIXEIRA, 2005), onde ocorrem a geração e o fluxo dos REEE institucionais. Foi utilizado o método de observação direta dentro desse contexto, com dados fornecidos de modo informal por gerentes locais de prevenção, zeladoria, almoxarifado, manutenção, administração, materiais, infraestrutura e outros envolvidos com os REEE na instituição. Neste caso, também se consideraram os REEE pertencentes às categorias indicadas nas Diretivas WEEE, RoHS e suas revisões, além da Diretiva 2006/66/CE sobre pilhas e acumuladores (UE, 2006).

$\mathrm{Na}$ análise dos dados obtidos nesta etapa, interessou tanto o processo quanto os resultados. Recorreu-se à aplicação de questionário e a entrevistas informais quando não 
houve fontes mais seguras para as informações complementares (CERVO e BERVIAN, 1996), necessárias para a elaboração do diagnóstico, uma vez que, após o processo de baixa patrimonial, os bens deixam de existir e, não há nenhum registro que possa indicar o seu destino.

Nesta pesquisa, a abordagem qualitativa foi utilizada para: a) investigar o fluxo externo dos REEE do QSD; b) levantar dados e diagnosticar o processo de gestão interna dos REEE institucionais; c) identificar os possíveis impactos econômicos, sociais, ambientais e na saúde do trabalhador causados pelo fluxo desses resíduos quando deixam a instituição; d) identificar possíveis fatores de influência na gestão externa desses resíduos.

A partir dos resultados do diagnóstico e sua avaliação, formularam-se diretrizes para a elaboração de um plano integrado de gestão sustentável e eficiente desses resíduos, que possa servir de instrumento para a orientação de outros planos institucionais de gestão.

\subsection{ETAPAS METODOLÓGICAS}

A pesquisa de campo foi realizada em três etapas:

ETAPA I - Pesquisa documental, exploratória e descritiva, para o entendimento da situação dos REEE no âmbito da UE, da Espanha e do Brasil.

ETAPA II - Pesquisa de campo, com abordagem híbrida, utilizando métodos de análise quantitativa e qualitativa, para complementar o diagnóstico da situação dos REEE, nas duas IES selecionadas para estudo. Esta etapa inclui a apresentação do diagnóstico aos envolvidos diretamente com a questão dos REEE, para coleta de subsídios para a proposta de diretrizes.

ETAPA III - Proposta de diretrizes para elaboração de um plano integrado de gestão de REEE institucionais. 


\subsubsection{Desenho da pesquisa de campo}

O desenvolvimento da pesquisa de campo subdividiu-se em três fases, delineadas de acordo com o objetivo geral e os objetivos específicos da tese, conforme apresentado na Figura 1.

Figura 1 - Desenho da pesquisa de campo

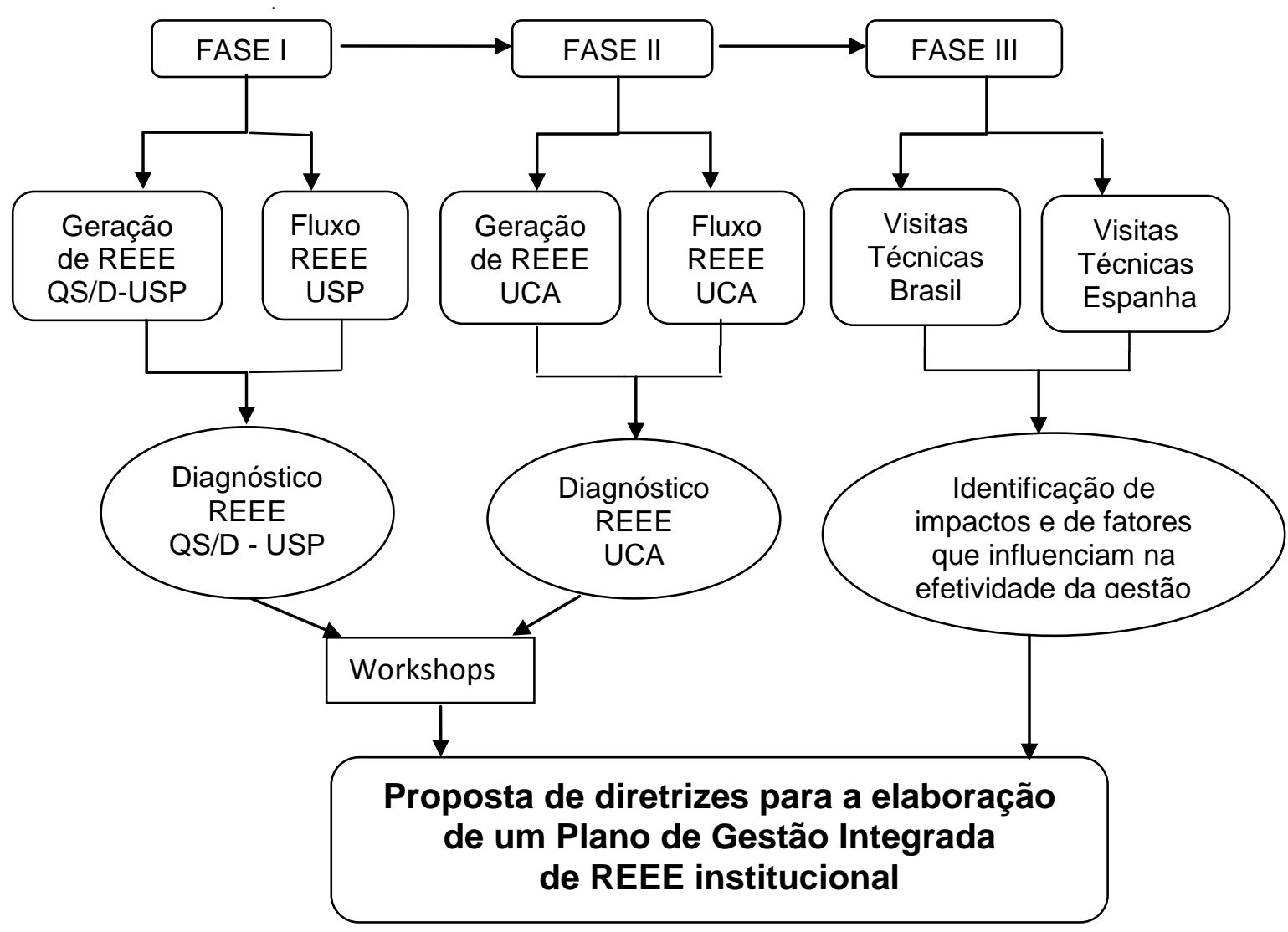

\subsubsection{Fontes de informação para elaboração do diagnóstico}

Inicialmente foram identificadas as fontes de informação, além dos recursos materiais e humanos, por meio dos quais se buscou obter os dados necessários para a elaboração do diagnóstico da geração e fluxo dos REEE, especificadas a seguir:

- Bases de dados disponíveis nas páginas web das duas IES pesquisadas, Cátedra RELEC e sites de empresas especializadas em gestão de REEE nos dois países.

- Sistema MERCURIO de Informação Gerencial da USP (SIAP). 
- Sistema de informação de baixa de bens patrimoniais da UCA (SICOC).

- Visitas às unidades das instituições pesquisadas, com aplicação de questionário semiestruturado para orientar as entrevistas e com registros fotográficos, quando permitidos.

- Visitas técnicas aos diferentes tipos de locais de destinação final de REEE.

- Serviço de Prevenção da UCA, responsável pela gestão dos REEE na instituição.

- Visitas técnicas aos nove principais SIG de REEE em operação na Espanha e a especialistas brasileiros e espanhóis sobre o tema de REEE.

\subsubsection{Apresentação e discussão do diagnóstico}

Nesta pesquisa, a apresentação do diagnóstico, nas duas IES estudadas, foi realizada por meio de workshop (USP) e por meio de entrevista diretamente com os envolvidos na gestão dos REEE (UCA). O motivo para uso de duas técnicas distintas foi de ordem prática. Enquanto na USP trabalhou-se com unidades pertencentes a uma única Coordenadoria e geograficamente próximas, na UCA o estudo incluiu todas as unidades da instituição, em quatro cidades diferentes. Utilizou-se para ambos os casos como roteiro um questionário não estruturado (APÊNDICE I).

Na USP, trabalhou-se com um grupo focal, constituído por representantes dos setores envolvidos com a questão dos REEE, das cinco unidades participantes do estudo. Entre esses estão os setores de Engenharia, Finanças, Administração, Compras, Informática, Manutenção, Almoxarifado, Zeladoria e outros. No workshop os participantes foram convidados a analisar as situações diagnosticadas, a apontar as dificuldades enfrentadas no desempenho de suas funções e a sugerir melhorias para a gestão de REEE em sua Instituição. Esta técnica pretendeu reunir elementos para construir uma gestão integrada e participativa, na qual todos os atores envolvidos com a questão tenham a oportunidade de opinar, sugerindo atividades e ações a serem consideradas. O workshop teve por objetivo a discussão dos dados e informações levantadas no diagnóstico e colher sugestões para a elaboração das diretrizes do plano integrado de REEE institucionais. Após a apresentação do diagnóstico, formaram-se grupos de discussão, de acordo com as áreas de atuação. 
Na UCA apresentou-se o diagnóstico individualmente, aos responsáveis por setores envolvidos diretamente com a gestão de REEE na instituição. De acordo com o interesse de cada setor, houve inserção ou exclusão de perguntas do questionário semiestruturado utilizado como roteiro para as entrevistas. Após a apresentação do diagnóstico, foram realizadas reuniões, para discussão de providências e possíveis medidas a adotar para melhorias na gestão integrada dos REEE.

O diagnóstico focou a situação atual da gestão atual dos REEE nas duas instituições estudadas e incluiu a estimativa de quantidades e tipos desses resíduos gerados na IES e de seu destino, para identificação de deficiências de infraestrutura, dificuldades operacionais e problemas de comunicação, considerando a cultura ambiental da organização. Os dados sobre segregação, formas de descarte e de destino dados aos REEE nas IES estudadas, após os procedimentos de baixa patrimonial, foram complementados em visitas às unidades das IES selecionadas, para contato com os respectivos responsáveis pelos departamentos envolvidos com a questão dos REEE. Esta etapa da pesquisa utiliza uma abordagem qualitativa.

A partir dos dados e informações levantadas nas duas IES, buscou-se identificar potenciais impactos ambientais, econômicos, sociais e à saúde, causados pelos procedimentos adotados e pelo fluxo desses resíduos em cada instituição, o que permitiu a identificação dos fatores de influência sobre a gestão institucional de REEE. 


\section{REVISÃO BIBLIOGRÁFICA}

Embora os REEE constituam uma problemática da atualidade, a história da eletricidade remonta a era antes de Cristo, com a observação do fenômeno de atração entre diferentes materiais, por Thales de Mileto (Século VI a.C.). Por sua vez, a eletrônica tem seu marco histórico no Século XIX, com a descoberta do efeito fotovoltaico por Becquerel em 1839 e a obtenção do primeiro componente eletrônico puro, a célula fotovoltaica (MEYER, 1971). Foi somente no Século XIX, com a Revolução Industrial na Inglaterra e, contribuições de grandes cientistas como Edison e Graham Bell e Thomsom, que tem início no século XX, a era da comunicação e dos equipamentos elétricos e eletrônicos (EEE). A seguir é feito um breve resumo dos principais acontecimentos que deram origem ao problema aqui estudado.

\subsection{ANTECEDENTES HISTÓRICOS}

- Século XX - Na primeira metade do século, duas guerras mundiais impulsionam o surgimento dos equipamentos de comunicação à distância e a popularização dos eletrodomésticos, nos Estados Unidos.

- 1947 - A invenção do transistor (transfer resistor), por Shockley, Brattain e Bardeen da Bell Labs, (GANAPATI, 2009) representa a gênese de uma nova era para a tecnologia eletrônica.

- 1954 - Lançamento do primeiro rádio transistor.

- 1958 - Kilby apresenta o primeiro circuito integrado em funcionamento.

- 1965 - Gordon E. Moore constata que a miniaturização permitiria dobrar o número de transistores em circuitos integrados a cada ano enquanto o custo permaneceria constante (MOORE, 1965), uma tendência que deveria manter-se por pelo menos mais $10 \operatorname{anos}^{1} \cdot$. Como consequência dessa previsão, surge a Lei

\footnotetext{
1 "The complexity for minimum components cost has increased at a rate of roughly a factor of two per year". MOORE (1965) entendia a complexidade como o número de componentes por chip (todo tipo de
} 
de Moore, que estabelece que "a qualquer momento, mesmo as máquinas consideradas muito avançadas encontram-se também à beira da obsolescência (MELO 2005)".

- Década de 1970 - A partir da construção do primeiro circuito integrado, no final da década, com a montagem miniaturizada de transistores, capacitores, resistores e diodos semicondutores montados em uma só base (BELLIS, 2011), novas tecnologias vêm sendo desenvolvidas para sua fabricação seriada em alta velocidade.

- 1971 - É lançado o primeiro "computador pessoal" (PC do inglês "Personal Computer") com 256 bytes de memória, projetado para uso educativo (ou seja, demonstrar como um "computador de verdade" funcionava). (COMPUTER HISTORY MUSEUM, 2011).

- Final da década de 1970 - Grandes empresas e bancos investem milhões de dólares para tornar mais eficientes alguns processos internos e o fluxo de informações. Essas organizações contam com computadores de grande porte (mainframes), trancados em salas refrigeradas e operados apenas por poucos. As empresas de menor porte ainda utilizam arquivos de metal, máquinas de escrever, papel carbono e memorandos para registrar suas operações (NOVA ELETRONICA, 2011).

- 1975 - Começa a ser comercializado nos Estados Unidos um kit para amadores, para montar o próprio PC, que se comunica com o usuário através de luzes que piscam. Os estudantes da Universidade de Harvard, Bill Gates e Paul Allen desenvolvem uma versão da linguagem "BASIC" para PC. Pouco tempo depois, fundam a MICROSOFT que, mais tarde cria o Windows, o qual se torna o sistema operativo para PC mais utilizado no mundo, por sua facilidade de operação para o usuário.

- 1976 - A dupla de jovens estudantes, da Universidade de Berkeley, Steve Jobs e Steve Wozniak, cria o Apple I, uma placa de circuito armazenada em uma caixa pouco maior. (Por esse motivo, fala-se hoje em 18 meses). 
de madeira, de modo bastante rústico e, funda nos Estados Unidos a APPLE, empresa que mudaria o rumo da informática, com a popularização do PC.

- 1977 - É lançado o primeiro microcomputador como conhecemos hoje - o Apple II - um equipamento já montado, com teclado integrado e capaz de gerar gráficos coloridos. As vendas chegam a US\$ 2,5 milhões no primeiro ano de comercialização (RASMUSSEN, 2009).

- 1979 - A APPLE COMPUTER torna-se a empresa de maior sucesso mundial da microinformática. Com o projeto de Jobs, de transformar o PC em dispositivo para as massas, o Apple II - já presente em escolas e residências da elite americana - começa a ficar obsoleto e a empresa depara-se com a necessidade de inovar para continuar competindo.

- 1980 - Surgem as primeiras aplicações práticas do conceito de nanotecnologia descrito pela primeira vez por Richard P. Feynman em 1959 (FORESIGHT, 2010), com o desenvolvimento de microscópios especiais (KNOWLEDGE CENTER, 2005).

- 1980 - Acelera-se a confecção e projetos de componentes e equipamentos eletrônicos. A nanotecnologia utiliza técnicas e ferramentas atualmente desenvolvidas para produzir equipamentos de alto desempenho. É referida como uma tecnologia para propósitos gerais, por seu impacto em quase todas as indústrias e todos os setores da sociedade (CRN, 2005).

- 1981 - Com o advento do IBM PC, os microcomputadores tornam-se ferramenta de trabalho importante para a gestão empresarial, introduzindo planilhas eletrônicas e processadores de textos e bancos de dados, impulsionando a demanda por tecnologia. (FONTE DE DADOS, 2011).

Os resultados dessa evolução resultam em equipamentos de desempenho cada vez mais alto, a custos cada vez mais baixos, permitindo que cada vez mais usuários tenham acesso a uma infinidade de novos produtos e trazendo grandes avanços para a indústria em geral e instituições de ensino e pesquisa, em particular, as quais são grandes consumidoras de equipamentos de TIC.

Apesar de sua longa trajetória, a geração de REEE é considerada um problema que apenas começa a surgir como tal na década de 1970 (REIDLER e GÜNTHER, 2002), com os primeiros sinais de alerta sobre o descarte de pilhas e baterias e as 
mudanças climáticas, na Conferência Mundial sobre o Meio Ambiente Humano, realizada pelas Nações Unidas em Estocolmo, um marco importante para as discussões sobre desenvolvimento e meio ambiente (ONU, 1972). E, a evolução continua. Em 2011 surge o chip que usa um transistor tridimensional em lugar de plano, como nos convencionais. O chip fabricado com o transistor TRI-GATE tem capacidade de processamento 37\% maior e consome metade da energia (PALÁCIOS, 2012). É mais uma confirmação da Lei de Moore.

\subsection{TENDÊNCIAS DE GERAÇÃO DE REEE}

Uma extensa gama de novos EEE e dispositivos portáteis vem ganhando crescente popularidade entre as novas gerações de adultos do século XXI. Estudo conduzido por ZICKUHR (2011) mostrou que os adultos mais jovens lideram o caminho no aumento da mobilidade, preferindo laptops a desktops e utilizando seus telefones celulares para múltiplas funções, como acesso à internet, envio de e-mails e mensagens de textos, câmera fotográfica, filmadora, leitores de mp3 e vídeo, jogos, agenda e e outras funcionalidades. O estudo conclui que os telefones celulares são, de longe, o dispositivo eletrônico mais popular entre os adultos americanos com idade inferior a 65 anos (PEW RESEARCH CENTER, 2011).

No Brasil, as estatísticas apontam para a mesma tendência de crescimento de consumo de EEE, em função de fatores, como população crescente, economia em expansão e aumento do poder aquisitivo, impulsionando consumo desses produtos. No setor de celulares, por exemplo, segundo a Agência Nacional de Telecomunicações, em março de 2012, o número desses aparelhos no país alcançou 250,8 milhões de unidades. Esses dados referem-se apenas a aparelhos com linhas ativas, o que significa uma densidade de 128 cel./100 hab. As adições líquidas do mês de janeiro (2,9 milhões) foram superiores as do mesmo mês de 2011 (2,2 milhões) e o crescimento acumulado no ano de 2011 foi de 19,4\% (ANATEL, 2012).

Esse aquecimento do setor de EEE apresenta como efeito colateral um aumento sem controle da geração de REEE e dos respectivos impactos ambientais. Por um lado, 
os sistemas de vendas ao consumidor são bem estruturados e geram grandes volumes de negócios. Por outro, não existe estrutura formal específica para a logística reversa, tratamento e disposição final desses resíduos no país (ARAUJO et al, 2012). Há várias empresas que atuam nesse mercado, mas não existe um padrão de procedimento. Milhares de pequenos negócios atuam nessa atividade, competindo pela mesma matéria prima, alimentando um amplo comércio de componentes usados e descartando de maneira ambientalmente inadequada as partes sem interesse comercial (DIAS, 2008). No APENDICE III, apresenta-se uma relação contendo algumas das principais empresas registradas oficialmente como recicladoras de REEE no Brasil.

Nos países mais ricos, que geram maiores quantidades de REEE per capita, existe mais capacidade de equacionamento de sua gestão sustentável, por uma conjunção de fatores que incluem recursos econômicos, preocupação ambiental da população e desenvolvimento tecnológico (JACOBI e BESEN, 2011). Além do expressivo crescimento da geração desses resíduos, observam-se ainda, ao longo dos últimos anos, mudanças significativas em sua composição e características e o aumento de sua periculosidade (OMS, 2007; EPA, 2010). Essas mudanças decorrem especialmente dos modelos de desenvolvimento pautados pela obsolescência programada e por elevados padrões de consumo desses produtos.

Em países emergentes como Brasil, Rússia, India e China (BRIC), grandes geradores de REEE em função do tamanho da população, a sustentabilidade da coleta seletiva diferencia-se pelo forte componente social da inclusão de catadores, que cresce também em outros países da América Latina e Caribe (MEDINA, 2007; GTZ, 2010), mas que não ocorre nos Estados Unidos e na União Europeia (MILANEZ, 2002; MEDINA, 2007), os quais possuem legislação específica sobre o tema e sistemas organizados de coleta. 


\subsection{OS REEE E SEUS IMPACTOS AMBIENTAIS, ECONÔMICOS, SOCIAIS E À SAÚDE.}

À medida que cresce a demanda pelo consumo de EEE, novas tecnologias são desenvolvidas e novos materiais vão sendo utilizados na fabricação dos equipamentos. A velocidade com que surgem novas tecnologias, tornando os equipamentos obsoletos em tempo cada vez menor, tem gerado um desafio constante nos países industrializados: encontrar soluções sustentáveis para os impactos dos REEE, em três dimensões: social, econômica e ambiental (CNUMAD, 1997).

As interrelações entre os conceitos de saúde e desenvolvimento sustentável considerando suas dimensões fundamentais tornam-se cada vez mais evidentes (GÜNTHER e GRIMBERG, 2006). Suas interações são complexas, incluindo os resíduos entre outros fatores relacionados (EEA, 2010). As questões envolvendo os diversos tipos de REEE têm sido amplamente discutidas, sobretudo entre países desenvolvidos. Os impactos ambientais, econômicos, sociais e na saúde gerados por esses produtos e seus componentes ocorrem durante todo o seu ciclo de vida, tendo inicio antes mesmo de sua fabricação (VOET, GUINÉE E HAES, 2000).

Os impactos dos EEE começam com a extração de matérias primas para a produção de EEE, geralmente recursos naturais não renováveis, o que resulta na degradação ambiental, representando uma contribuição importante para as mudanças climáticas, um dos maiores problemas ambientais da atualidade. Seu processamento requer também o uso de grandes quantidades de água e energia, além de liberar inúmeras substâncias poluentes no ambiente. O processo produtivo envolve uma infinidade de necessidades associadas, tais como infraestrutura, recursos econômicos, tecnologia, espaço físico, grandes quantidades de energia, matérias primas, insumos, mão de obra especializada e transporte, entre outras. Um único chip de memória RAM de 2,0 g consome 1,7 quilos de combustíveis fósseis e substâncias químicas para ser produzido, o que corresponde a cerca de 400 vezes o seu peso (KUEHR R; WILLIAMS. E. 2003).

Durante a etapa de vida útil dos EEE, vivemos constantemente expostos a campos invisíveis de ondas de rádio, ondas de televisão, microondas, radiações de 
diferentes tipos de radiação, campos eletromagnéticos, radar e redes Wi-Fi. Um exemplo típico é o dos telefones celulares, que entraram em uso generalizado nos países nórdicos, na década de 1980 e, nos Estados Unidos, na década de 1990. A exposição à nova fonte de ondas de rádio não-ionizante, através de uma antena comumente instalada para funcionar próxima à cabeça do usuário, causou preocupação no âmbito da saúde pública, dando início a uma série de estudos epidemiológicos em larga escala, nos Estados Unidos e em todo o mundo. Os resultados desses não são conclusivos sobre riscos de câncer associados e não há provas sobre a radiação não-ionizante emitida pelos telefones celulares (BOICE e TARONE, 2011).

Por outro lado, o celular tornou-se parte integrante da vida cotidiana Em 2009, havia mais de 285 milhões de assinantes de serviço de telefonia celular nos Estados Unidos (91\% da população) e mais de cinco bilhões de todo o mundo (BOICE e TARONE, 2011), contribuindo com um aumento considerável da geração de REEE. É crescente a preocupação com os EEE pós-consumo, em função da toxicidade de centenas de substâncias químicas contidas em seus componentes, especialmente quando incinerados ou reciclados em condições não controladas, ou descartados de maneira inadequada (WIDMER et al., 2005). Além de metais pesados, outras substâncias ainda mais nocivas como dioxinas, furanos, poliaromáticos halogenados, bifenilas policloradas, retardadores de chama bromados, amianto e arsênio (NCM, 1995) podem ser liberadas decorrentes de operações de reciclagem e da disposição inadequadas dos REEE. Algumas dessas dioxinas foram classificadas como carcinogênicas pelo International Agency for Research on Cancer (IARC) (WHO, 2008), representando um problema para a saúde pública e ambiental. A exposição direta a esses poluentes orgânicos persistentes (POPs) em ambientes de trabalho, por meio das vias respiratórias, é também motivo de grande preocupação por seu impacto na saúde do trabalhador em particular e na saúde pública em geral.

Em função da rápida proliferação de informação e comunicação (TIC), a popularização global do uso de computadores e outros eletrônicos de consumo têm aumentado a uma taxa sem precedentes. Embora esta "revolução digital" tenha o potencial de expandir a economia os e os níveis sociais de uma maneira inédita, também tem sido foco de crescente preocupação, os impactos ambientais e sociais potencialmente negativos associados ao uso, fabricação e destino ao final de vida útil 
dos EEE gerenciamento de computadores e outros produtos eletrônicos. Em particular, a disposição desses equipamentos pós-consumo, também denominado "lixo eletrônico" ou $e$-waste, tem estado sob crescente controvérsia e escrutínio por parte dos fabricantes, consumidores, organizações não-governamentais e reguladores, por causa dos potenciais danos ambientais, sociais, econômicos e de saúde, dependendo da forma como esses produtos são gerenciados (BABBITT, 2011).

Contudo, em função das dificuldades e dos altos custos de reciclagem dos REEE, grandes quantidades de EEE obsoletos, usados ou novos, têm sido enviadas de países industrializados a países em desenvolvimento, onde mais baixos padrões ambientais e precárias condições de trabalho tornam sua reciclagem mais lucrativa (SCHMIDT, 2006), causando impacto social negativo. É comum a prática da exportação de "sucatas" disfarçadas de equipamentos novos, como no caso dos aparelhos de TV e monitores de vídeo de tubos de raios catódicos (TRC), que chegam ao seu destino a preço de custo e podem funcionar ainda por algum tempo antes de se tornarem efetivamente resíduos. Inclusive componentes defeituosos, que não são aprovados no controle de qualidade, são reclassificados como válidos e exportados para países mais pobres, onde nem sempre são reciclados corretamente (UBA, 2010), contrariando a Convenção da Basiléia (ONU, 1988) que estabelece um mecanismo internacionalmente harmonizado de controle dos movimentos transfronteiriços de resíduos perigosos, da qual o Brasil é signatário, desde 1992.

Com relação a impactos econômicos negativos, estudo encomendado pela Agência Federal de Meio Ambiente da Alemanha e realizado pelo Instituto para Estratégias Ambientais de Hamburgo (SANDER e SCHILLING, 2010) aponta para a necessidade de promover a reciclagem dos REEE dentro do país de origem e alerta para o fato de que não só são exportados materiais perigosos, como também matérias primas valiosas, que poderiam permanecer no ciclo de vida do produto e gerar impacto positivo na economia do país. Por outro lado, os custos envolvidos em transporte, que podem ser muito maiores do que seriam os de transferência de tecnologia, resultam também em impacto econômico negativo. As autoridades competentes da EU devem intensificar a supervisão de exportações de REEE para garantir que os produtos que se pretendem exportar não são resíduos e que funcionam corretamente, para colocar um freio nos impactos negativos provocados por esse tipo de atividade (ECOLEC, 2011). 


\subsection{GESTÃO SUSTENTÁVEL E INTEGRADA DE REEE}

Segundo FIEN (2002), sustentabilidade é um conceito, um objetivo e uma estratégia. O conceito de sustentabilidade, hoje mundialmente aceito, surgiu pela primeira vez em 1972, na Conferência Mundial das Nações Unidas, sobre o homem e o meio ambiente em Estocolmo. O documento final resultante desse evento, conhecido como Relatório Bruntland define o desenvolvimento sustentável como sendo "aquele que atende às necessidades do presente sem comprometer as possibilidades de gerações futuras atenderem suas próprias necessidades" (UN, 1987).

A União Europeia formulou os três pilares da sustentabilidade na Conferência de Cúpula de Copenhague e no Tratado de Amsterdã de 1997. Esse princípio, denominado "Modelo de Sustentabilidade de Três Pilares", declara que a sustentabilidade não apenas abrange a herança da natureza que transmitimos para as próximas gerações, mas significa também, a inclusão das realizações econômicas e as instituições sociais. O desenvolvimento sustentável, portanto, fundamenta-se em cada um dos pilares: ambiental, econômico e social. Do ponto de vista de intervenção humana, a economia deve respeitar os limites naturais dos ecossistemas e agir de acordo com os princípios de equidade social. Se faltar um dos três pilares, a sustentabilidade se rompe (GOETHE INSTITUT, 2008).

Cada vez mais, o conceito de gestão ambiental vem sendo utilizado para incluir, programas desenvolvidos por empresas e instituições de todos os tipos, de modo a administrar as suas atividades dentro dos modernos princípios de proteção do meio ambiente. A gestão ambiental tem evoluído em direção a uma perspectiva de gestão e de responsabilidade compartilhada entre os diferentes agentes envolvidos e articulados em seus diferentes papeis (SEIFFERT, 2007). A literatura sobre economia da inovação, administração organizacional e gestão ambiental tem destacado, ao longo da última década, a importância dos Sistemas Integrados de Gestão e, várias têm sido as tentativas de reproduzir essa experiência, nos mais variados ambientes e setores.

Segundo SÁNCHEZ e CASTRO (2011), sistema de gestão ambiental é configurado pelas ações de caráter ambiental de uma instituição, realizadas de forma 
conjunta, planejada e organizada, proporcionando um processo estruturado para a melhoria contínua do desempenho ambiental da organização e inclui a gestão de resíduos como uma das ramificações fundamentais.

O conceito de gestão de resíduos abrange atividades referentes à tomada de decisões estratégicas e à organização do setor para esse fim, envolvendo instituições, políticas, instrumentos e meios (SÃO PAULO, 1996). A gestão integrada, sustentável e participativa de resíduos é um conceito em construção, que pode ser entendido em três níveis distintos, intimamente ligados: 1) as etapas de gerenciamento; 2) a busca da intersetorialidade com a articulação das diferentes áreas envolvidas com a temática dos resíduos; 3) a busca da integração entre os diferentes setores com o envolvimento de múltiplos agentes sociais, em ações coordenadas (GÜNTHER e GRIMBERG, 2006). Diálogos sobre a sustentabilidade são, em última análise, uma discussão de valores individuais e coletivos (VAN WYNSBERGH et al., 2002). O valor focado no modelo dessa visão ajuda os participantes a considerar os valores que reforçam objetivos e usa esses valores como entrada para tomada de decisão (KEENEY, 1992).

As distintas etapas do gerenciamento de REEE, desde sua geração até a disposição final, envolvem fatores de riscos à saúde para as populações expostas, especialmente para as pessoas que trabalham em contato direto com esses resíduos e as que vivem próximas às áreas de disposição final (OPS, 2005). De acordo com CASTRO e SÁNCHEZ (2011), um sistema de gerenciamento de resíduos compreende a coleta, o armazenamento, o transporte, a valorização a eliminação desses resíduos e inclui a vigilância dos locais de disposição final. Além disso, para estabelecer um sistema mais eficiente e sustentável, no caso dos REEE é fundamental que se respeite a hierarquia das etapas de gestão pela ordem:

- Prevenção: o conjunto de medidas destinado a evitar a geração de resíduos, ou a conseguir sua redução, ou a quantidade de substâncias perigosas, ou de contaminantes em seu conteúdo.

- Reutilização: o emprego de um produto usado para o mesmo fim para o qual foi desenhado originariamente, ou para outros fins, sem que ocorra reprocessamento.

- Reciclagem: a transformação dos resíduos, dentro de um processo de produção, para seu fim inicial ou para outros fins. 
- Valorização: todo procedimento que permita o aproveitamento dos recursos contidos nos resíduos, sem colocar em risco a saúde humana e sem utilizar métodos que possam causar danos ao meio ambiente.

- Eliminação: todo procedimento dirigido, tanto a sua disposição final como a sua destruição total ou parcial, realizado sem colocar em risco a saúde humana e sem utilizar métodos que possam causar danos ao meio ambiente.

As diferentes abordagens de gestão e gerenciamento de resíduos encontradas na literatura apontam uma tendência de gestão integrada de REEE que considera aspectos fundamentais da sustentabilidade em todas as etapas de seu gerenciamento, respeitando a hierarquia de prevenção e da reutilização de resíduos, antes do processo de logística reversa para reciclagem e/ou tratamento e disposição final. Essa visão representa uma evolução do conceito de minimização de resíduos proposto anteriormente (DOUGLAS, 1988; EPA, 1084), que se iniciava com medidas tomadas a partir da geração de resíduos. Essa visão norteou o caminho desta pesquisa, levando a abordar um conceito mais amplo de gestão integrada de REEE em IES, que se inicia com o planejamento da aquisição dos EEE e que considera atores sociais, econômicos, ambientais e de saúde em todas as etapas do ciclo de vida do produto. Este estudo busca integrar os diferentes aspectos da gestão institucional às etapas do gerenciamento dos REEE.

\subsection{GESTÃO DE REEE EM INSTITUIÇÕES DE ENSINO (IES)}

Os REEE surgem como problemática relativamente recente adicionada ao fluxo de resíduos nas IES e vem atraindo a preocupação de seus gestores, por seu volume crescente, diversidade e velocidade de geração. O tema representa um grande desafio para as universidades, quando se trata de aplicar na prática o conceito de desenvolvimento sustentável. Globalmente, essas instituições estão sendo confrontadas com este desafio em diferentes formas e níveis. As áreas que abordam a inclusão do desenvolvimento sustentável vão desde o ensino e a pesquisa até a gestão

administrativa. É fundamental considerar as diferentes atividades e operações em que as universidades estão envolvidas, como a pesquisa e a educação, o engajamento da gestão 
em formular politicas públicas e colaborar com organizações externas e, finalmente, o envolvimento na formulação de sua missão, onde reflita valores essenciais, que motivarão e darão suporte, de forma visível tanto aos stakeholders internos como externos (VAN WEENEN, 2000). De acordo com BABBITT (2011), além de fatores tradicionais de desempenho, custo e segurança, as considerações ambientais representam um papel crescente na gestão dos REEE nesssas instituições. Caracterizar as práticas de disposição atuais para fim de vida útil dos EEE é um passo fundamental no desenvolvimento de políticas que previnam impactos ambientais e de saúde, maximizando o potencial de benefícios sociais e econômicos embora reutilização.

Em estudo sobre sustentabilidade em IES, após a análise das transcrições das entrevistas e dos resultados da oficina realizada com um grupo constituído por docentes e alunos do Centre for Sustainable Community Development, na University of British Columbia, MOORE (2005) elaborou uma lista de recomendações e sugestões para um programa de educação para sustentabilidade. Essas são divididas em sete categorias com o objetivo de auxiliar as universidades em uma transformação, no sentido de uma visão de longo prazo da sustentabilidade e sugerem maneiras de transformar as estruturas da universidade para promover e apoiar a prática de "educação para sustentabilidade", mas não incluem recomendações para criar uma "universidade sustentável". Diálogos sobre a sustentabilidade são, em última análise uma discussão de valores individuais e coletivos (VAN WYNSBERGH et al., 2002).

Encontram-se na literatura muitas experiências interessantes de gestão de REEE em IES, relatadas como parte de um plano de resíduos dentro de uma política de resíduos. Destaca-se um estudo realizado pela Universidade de Southampton, situa da no sul da Inglaterra, que faz uma análise crítica dos motivos pelos quais a gestão sustentável de resíduos tornou-se uma questão fundamental para o setor em todo o mundo e descreve alguns dos benefícios, barreiras, práticas e problemas logísticos. De acordo com os autores, três medidas são fundamentais para se conseguir um sistema de gestão institucional de resíduos sustentável: mudança de infraestrutura, prestação de serviços, e mudança de comportamento (ZHANG e col; 2011).

BABBITT (2011) realizou na Universidade de Arizona, a primeira caracterização de quantidade, valor, disposição e fluxos após o fim de vida util dos REEE, em uma grande instituição educacional dos EUA. Os resultados do estudo 
empírico indicam que a maioria dos REEE da instituição, ao final de sua vida util, foi revendida por meio de leilão público para indivíduos e pequenas empresas, que recondicionam os equipamentos para revenda ou vendem esses resíduos para sucateriros. Essa avaliação detalhada foi acoplada a uma pesquisa de benchmarking de boas práticas de gestão de REEE ao fim de vida sua vida util em outras universidades norte-americanas. Os resultados dessa pesquisa indicam que, apesar de os leilões ainda serem comuns, um número crescente de instituições está respondendo às preocupações ambientais com a criação de parcerias com entidades de reciclagem e de revenda locais, além da obrigatoriedade da reciclagem doméstica. O estudo conclui que uma questão chave na gestão dos REEE da instituição é a decisão entre os benefícios de vendas de equipamentos usados, em termos de renda para a instituição e a reutilização maior para a sociedade, além dos riscos ambientais em funcao do desconhecimento das práticas ocorridas após os REEE deixarem a instituição.

Os resultados de um estudo de caso comparativo realizado na Noruega, sobre sistemas de logística reversa para REEE, (FLYGANSVÆR; GADDE; HAUGLAND, 2008) indicam que a falta de coordenação entre os fluxos aumenta os custos e reduz o nível de serviço e, um baixo nível de ação coordenada é alcançado. Em contraste, mostram que o bom funcionamento de mecanismos de coordenação entre os fluxos diminue os custos e aumenta a qualidade dos serviços. Mostram também, que as caracteristicas do consumidor final são forças motrizes que conduzem a diferentes tipos de sistemas de logística reversa. Há grande variedade nas características dos fluxos físicos e interesses comerciais. Assim, a diversidade nos sistemas exige diferentes tipos de mecanismos de coordenação, a fim de assegurar o desempenho do sistema de gestão. A coordenação dos fluxos físicos precisa de ser adaptado aos padrões de coleta, enquanto que a coordenação dos interesses comerciais precisapara se adaptar ao tipo de comportamento.

Segundo LEE (2012) o desempenho ambiental é diretamente influenciado por motivos instrumentais e motivos políticos, que têm efeitos indiretos sobre o desempenho ambiental através da responsabilidade ambiental das instituições. Um estudo realizado por CHEN et al (2012) mostra que as inovações "verdes" podem ter origem interna ou externa à organização e as classifica em proativas e reativas. Os 
resultados apontam para a legislação como um forte fator de influência nas inovações reativas, enquanto que as proativas, geralmente, são resultado de fatores internos.

Ao conhecermos concretamente o funcionamento das IES quanto à gestão dos REEE (compra, ciclo de vida, políticas) será possível disseminar melhores as práticas e formar colaboradores para melhor gerenciar este e outros tipos de resíduos. Uma das opções de política, consideradas por KHETRIWAL, KRAEUCI e WIDMER (2007) como das mais promissoras, para a gestão de REEE na Europa, consiste em estender a responsabilidade dos produtores para além do ponto de venda, até o final de vida do produto. Essa é a política atualmente adotada no continente europeu.

Entende-se por responsabilidade extendida do produtor (Extended Producer Responsibility - ERP) "uma estratégia de proteção ambiental que obriga que o fabricante do produto se responsabilize por todo seu ciclo de vida e, especialmente por sua devolução (take back) ou coleta, reciclagem e disposição (LINDHQVIST, 2000)”. Com isso, a responsabilidade do produtor é extendida à etapa pós-consumo do ciclo de vida de vida do produto. (OECD, 2001). 


\subsection{MARCO LEGAL NA UNIÃO EUROPEIA}

A partir do final da década de 1980, cresce em alguns países da Europa, a preocupação com o aumento da geração dos resíduos tecnológicos, resultando na aprovação da Lei de Resíduos (CE, 91/156/CEE), que modifica a legislação anterior, vigente desde 1975 (CE, 75/422/CEE). A nova lei representa um grande avanço para a UE, com um conceito inovador de Política de Resíduos, em que abandona sua classificação em duas modalidades (gerais e perigosos) e estabelece uma norma comum para todos os tipos de resíduos, que poderá ser complementada com uma legislação específica, para determinadas categorias. Assim, novas diretivas são criadas, para regulamentar os resíduos tecnológicos.

\subsubsection{Diretiva sobre Pilhas e Acumuladores}

A Diretiva 91/157/CEE do Conselho, de 18 de março de 1991, sobre pilhas e acumuladores que contenham determinadas substâncias perigosas, impõe aos Estados membros a obrigação de adotar as medidas oportunas para a coleta seletiva de pilhas e acumuladores, usados, para sua valorização ou sua eliminação (CCE, 1991). A Diretiva 2006/66/CE do Parlamento Europeu e do Conselho, de 6 de setembro, relativa a pilhas e acumuladores e respectivos resíduos, revoga a Diretiva 91/157/CEE (JORNAL OFICIAL DA UNIÃO EUROPEIA, 2006) e seu texto é relevante para efeitos dos EEE. A nova diretiva abrange todos os tipos de pilhas e baterias e seus resíduos, incluindo tanto as de consumo doméstico (portáteis), como as automotivas e as de uso industrial. Determina a obrigatoriedade dos produtores em criar sistemas de logística reversa, com coleta e reciclagem ou disposição final, para todos os tipos. Limita o teor de metais pesados (cádmio, chumbo e mercúrio).

\subsubsection{Lista Europeia de Resíduos}

Conforme a Decisão 2000/532/CE, de 3 de maio, modificada pelas Decisões 2001/118/CE, de 16 de janeiro e 2001/119/CE, de 22 de janeiro, da Comissão Europeia e, pela Decisão 2001/573, de 23 de julho, do Conselho Europeu, publicam-se as operações de valorização e de eliminação de resíduos e, a Lista Europeia de Resíduos (LER), que funde em uma única lista os resíduos perigosos e não perigosos. Conforme a 
Diretiva 91/689/CEE, são considerados resíduos perigosos, aqueles que aparecem na LER assinalados com um asterisco e a cujas disposições estão sujeitos. A referida lista inclui os REEE no Código “16.02, conforme o estabelecido no Quadro 1.

Quadro 1 - Classificação dos REEE na Lista Europeia de Resíduos (LER)

\begin{tabular}{|c|c|c|}
\hline Código LER & Denominação & Perigoso/Não Perigoso \\
\hline 160209 * & Transformadores e condensadores que contêm PCP & Perigoso \\
\hline $160210^{*}$ & $\begin{array}{l}\text { Equipamentos descartados que contêm PCP, ou } \\
\text { estão contaminados por estes, distintos dos } \\
\text { especificados no código } 160209 .\end{array}$ & Perigoso \\
\hline $160211^{*}$ & $\begin{array}{l}\text { Equipamentos descartados que contêm } \\
\text { fluorclorocarbonos, HCFC. }\end{array}$ & Perigoso \\
\hline $160212^{*}$ & Equipamentos descartados que contêm amianto livre & Perigoso \\
\hline $160213^{*}$ & $\begin{array}{l}\text { Equipamentos descartados que contêm } \\
\text { componentes perigosos (4), distintos dos } \\
\text { especificados nos códigos } 160209 \text { a } 160212\end{array}$ & Perigoso \\
\hline 160214 & $\begin{array}{l}\text { Equipamentos descartados, distintos dos } \\
\text { especificados nos códigos } 160209 \text { a } 160213\end{array}$ & Não Perigoso \\
\hline $160215^{\star}$ & $\begin{array}{l}\text { Componentes perigosos retirados de equipamentos } \\
\text { descartados. }\end{array}$ & Perigoso \\
\hline 200116 & $\begin{array}{l}\text { Componentes retirados de equipamentos } \\
\text { descartados, distintos dos especificados no código } \\
160215 .\end{array}$ & Não Perigoso \\
\hline $200123^{*}$ & $\begin{array}{l}\text { Equipamentos descartados que contêm } \\
\text { fluorclorocarbonos. }\end{array}$ & Perigoso \\
\hline $200135^{\star}$ & $\begin{array}{l}\text { Equipamentos elétricos e eletrônicos descartados, } \\
\text { distintos dos especificados nos códigos } 200121 \text { e } \\
200123 \text { e que contêm componentes perigosos (9). }\end{array}$ & Perigoso \\
\hline 200136 & $\begin{array}{l}\text { Equipamentos elétricos e eletrônicos descartados, } \\
\text { distintos dos especificados nos códigos } 200121 \text {, } \\
200123 \text { e } 200135 \text {. }\end{array}$ & Não Perigoso \\
\hline
\end{tabular}

Fonte: Lista Europea de Residuos

(4) e (9) os componentes perigosos dos EEE podem incluir as pilhas e acumuladores, classificados como perigosos no subcapítulo 16 - 06, assim como os interruptores de mercúrio, vidros procedentes de tubos catódicos e outros cristais ativados. 


\subsubsection{Diretivas WEEE e RoHS}

Após mais de uma década de discussão, o Parlamento Europeu (PE) e o Conselho Europeu (CE) aprovam, em 27 de janeiro de 2003, duas diretivas para regulamentar a questão dos REEE: a Diretiva 2002/96/CE (conhecida como WEEE “Waste Electrical and Electronic Equipment”) e a Diretiva 2002/95/CE (RoHS "Restriction of Hazardous Substances in Electrical and Electronic Equipment") (PARLAMENTO EUROPEU, 2002), estabelecendo o prazo para suas transposições, para as legislações dos países membros, até 13 de agosto de 2004.

A Diretiva WEEE determina que os produtores sejam responsáveis pela coleta e reciclagem dos REEE e estabelece metas. Aplica-se a empresas que fabricam, importam, exportam, distribuem e comercializam EEE em toda a UE. Seu principal objetivo é reduzir a geração de REEE e melhorar o desempenho ambiental de todos os atores e processos envolvidos no ciclo de vida desses produtos, desde sua concepção, até o destino final. Com data limite para a sua entrada em vigor nos países membros da UE até 13 de agosto de 2005, a versão original da Diretiva WEEE regula a gestão de uma grande diversidade de REEE e de determinados equipamentos de uso profissional (mas não inclui os componentes). O modelo de política adotado baseia-se em conceitos de Princípios da Precaução ${ }^{2}$, do Poluidor-Pagador ${ }^{3}$ e da Responsabilidade Estendida do Produtor $^{4}$ (DIRETIVA WEEE 2002/96/CE). (PARLAMENTO EUROPEU, 2002).

A Diretiva RoHS exige a substituição de alguns metais pesados (chumbo, mercúrio, cádmio e cromo hexavalente) e dos retardadores de chama bromados [(bifenilas polibromadas (PBB) e éteres difenílicos polibromados (PBDE)] em EEE, colocados no mercado após $1^{\circ}$ de Julho de 2006 (DIRETIVA2002/95/CE).

\footnotetext{
${ }^{2}$ Princípio da Precaução: proposto formalmente na Conferência Mundial para o Meio Ambiente Rio 92. ${ }^{3}$ Poluidor-Pagador: formalmente incorporado pela OCDE, ainda em 1972, sendo assumido, em 1973, pela CEE.

${ }^{4}$ Responsabilidade Estendida ao Produtor: Principio de política que atribui aos produtores e importadores a responsabilidades física, econômica, legal e informativa pelos impactos ambientais de seus produtos em todas as fases do ciclo de vida (LINDHQVIST, 2000).
} 


\subsubsection{Definições segundo a Diretiva WEEE}

Os conceitos utilizados para realizar pesquisa estão definidos na Diretiva WEEE (UE, 2002/96/CE) e os principais são resumidos a seguir:

- Equipamentos Elétricos e Eletrônicos (EEE) são aqueles cujo funcionamento adequado depende de correntes elétrica ou campos eletromagnéticos, bem como os equipamentos para geração, transferência e medição dessas correntes e campos pertencentes às categorias definidas no Anexo I A, da Diretiva 2002/96/CE e destinados à utilização com uma tensão nominal não superior a $1.000 \mathrm{~V}$ para corrente alternada e $1.500 \mathrm{~V}$ para corrente contínua (PARLAMENTO EUROPEU, 2003 a).

- Resíduos de Equipamentos Elétricos e Eletrônicos (REEE) consiste em EEE, nos termos da alínea "a" do artigo $1^{\circ}$ da Diretiva 75/442/CEE, que se deseja descartar, incluindo todos os componentes, subconjuntos e materiais consumíveis que fazem parte do produto no momento em que este é descartado (PARLAMENTO EUROPEU, 2003 b).

- Categorias de REEE - A Diretiva WEEE classifica os REEE em 10 categorias:

1. Grandes eletrodomésticos

2. Pequenos eletrodomésticos

3. Equipamentos de informática e telecomunicações

4. Equipamentos eletrônicos de consumo

5. Equipamentos de iluminação

6. Ferramentas elétricas e eletrônicas

7. Brinquedos e equipamentos para esporte e lazer

8. Equipamentos médicos

9. Instrumentos de medição e controle

10. Máquinas de venda automática

- Categorias operacionais de REEE - Segundo o tipo de reciclagem, as empresas de reciclagem classificam os REEE em cinco categorias.

1. Equipamentos de refrigeração 
2. EEE grande s e médios (exceto os da categoria 1)

3. Lâmpadas e equipamentos de iluminação

4. Televisores e equipamentos com monitores (TRC, plasma, LCD e outros)

5. Outros EEE

- Classificação por linhas de cor - A classificação em categorias por linhas de cor, em linha branca, linha marrom e linha cinza não é definida na Diretiva 2002/96/CE, mas é, provavelmente, a mais conhecida do ponto de vista dos consumidores. Cabe salientar que linha cinza não é o mesmo que "mercado cinza", assim denominado por alguns fabricantes e importadores de EEE no Brasil, referindo-se aos produtos piratas, comercializados ilegalmente no país. Os nomes das três linhas resultaram das cores mais comuns em que eram fabricados esses equipamentos, no inicio de seus lançamentos no mercado. Assim, a linha branca corresponde a grandes eletrodomésticos, a marrom consiste principalmente de equipamentos de áudio e vídeo e a cinza, de equipamentos de informática e telecomunicações. No entanto, à medida que novos produtos são desenvolvidos e, novos desenhos e cores vão surgindo, torna-se cada vez mais difícil a sua classificação por categoria de cor.

\subsubsection{Transposição das Diretivas para as legislações nacionais}

A transposição das Diretivas WEEE e RoSH para as legislações nacionais dos países membros da UE acompanhada e atualizada por Pechards, em uma série de relatórios que registram o seu progresso em cada um destes, desde o início. Entre outras informações, incluem-se as datas chave das transposições e as medidas adotadas em cada caso. Alguns países, por não possuírem nenhuma legislação referente ao tema, adotam as próprias Diretivas por decreto. Outros criam novas leis ou fazem emendas a legislações já existentes (PECHARDS, 2007).

As disposições são obrigatórias a todos os estados membros. Cada país membro deve exigir o registro de todos os produtores, os quais devem criar sistemas de coleta (take back) e garantir seu financiamento, estabelecer responsabilidades e metas, criar mecanismos para gestão de REEE dos novos equipamentos colocados no mercado e também do estoque histórico. Os sistemas de gestão de REEE autorizados, registrados e homologados em cada país, devem encaminhar relatórios anuais de seus resultados ao órgão de seu governo, responsável por apresentá-los à Comissão de REEE, do Conselho 
Europeu. A Câmara de Compensação e a taxa visível nos produtos são opcionais e aparecem em alguns países (RELEC, 2005).

\subsubsection{A experiência da aplicação das Diretivas WEEE e RoSH na União Europeia}

As Diretivas WEEE e RoSH produzem impacto global na indústria de EEE, afetando fabricantes de equipamentos e de componentes, importadores, revendedores e clientes sediados na Comunidade Econômica Europeia (CEE), ou que mantenham ou planejam ter relações comerciais com qualquer país membro da EU (ORGALIME, 2011). O atraso significativo no cumprimento dos prazos estabelecidos, por parte dos países membros, reflete a complexidade das Diretivas da UE. A divergência dos requisitos para o registro dos produtores resulta na necessidade de se respeitar 27 regimes diferentes dentro da UE, além dos quatro países integrantes do acordo de livre comercio com a UE - European Free Trade Association (EFTA) (Suíça, Liechtenstein, Noruega e Islândia).

A experiência com os quatro primeiros anos de aplicação das Diretivas na UE revela problemas de ordem técnica, jurídica e administrativa. A falta de harmonização das legislações nacionais resultou em distorções na interpretação das normas, com danos ambientais contínuos e encargos administrativos desnecessários. Não há clareza sobre os produtos abrangidos pela Diretiva WEEE e sobre a sua categorização (EUROPEAN COMISSION, 2008).

A taxa de coleta imposta pela Diretiva WEEE, de $4 \mathrm{~kg} /$ habitante/ano de REEE proveniente de particulares (a mesma medida serve para todos os países - "one size fits all"), não reflete a realidade das economias dos Estados Membros, fazendo com que a metas sejam subestimadas para alguns países e muito ambiciosas para outros. A Diretiva 2002/96/CE não estabelece requisitos de reutilização de equipamentos inteiros. Os relatórios anuais mostram que 65\% dos EEE colocados no mercado são coletados separadamente, mas menos da metade desse material é tratada de acordo com os requisitos da Diretiva WEEE. O restante desses resíduos, potencialmente perigosos, pode estar sendo encaminhado a locais clandestinos, tratado inadequadamente, causando impactos negativos ao ambiente e à saúde pública, ou sendo exportado para países não pertencentes à Organização para a Cooperação e Desenvolvimento Econômico OCDE (EUROPEAN COMISSION, 2008). 


\subsubsection{Revisão das Diretivas WEEE e RoHS}

Em dezembro de 2008, a Comissão de REEE do Conselho Europeu propõe uma revisão das Diretivas WEEE e RoHS, com o objetivo de melhorar sua implementação e cortar encargos administrativos desnecessários. Essa revisão está prevista na versão original da Diretiva WEEE2002/96/CE, com base na experiência de sua aplicação e tem como objetivos específicos:

- Melhorar a eficácia da coleta seletiva de REEE (incluídos os equipamentos destinados aos consumidores particulares).

- Fomentar a preparação para a reutilização de todos os REEE, aumentando (+5\%) o objetivo para a reciclagem.

- Reduzir os custos e os encargos administrativos desnecessários para os produtores, harmonizando as obrigações nacionais de apresentação de relatórios e de registro, fazendo com que sejam interoperativos, propondo uma nova definição de produtor em nível da UE (CONSEJO DE LA UNIÓN EUROPEA, 2008).

Em 14 de março de 2011, após mais de dois anos de trabalho, o Conselho de Ministros de Meio Ambiente da UE consegue, por unanimidade, um acordo político sobre a proposta de revisão da Diretiva 2002/96/EC (COUNCIL OF THE EUROPEAN UNION, 2011), a qual está intimamente ligada e é complementar à proposta de revisão da Diretiva 2002/96/EC (RoHS) (COUNCIL OF THE EUROPEAN COMISSION, 2011). O acordo político baseia-se na proposta de que a nova meta de coleta e reciclagem de REEE da UE considere o volume de REEE gerados e (FLORENZ, 2011) e não a quantidade (em peso) de novos equipamentos e materiais vendidos, conforme o modelo proposto anteriormente. Fica acordado que os estados membros da UE deverão fazer a gestão adequada de $85 \%$ dos REEE gerados a partir de 2016, aumentando em $20 \%$ a meta que havia sido aprovada na proposta anterior. Não obstante, a maneira como será calculada a meta de $85 \%$ não está clara. Fica estabelecido como meta provisória para o ano de 2012, que a coleta seja maior que os 4,0 kg por habitante ou, que seja maior do que o equivalente à quantidade de REEE coletados em 2010.

Em função dos diferentes níveis de geração de REEE, nos diferentes estados membros, dispõe-se de suficiente liberdade para fixar metas nacionais mais elevadas. Faz-se uma chamada para que os equipamentos inteiros reutilizáveis sejam mantidos em separado de outros REEE, comum à meta de reutilização de 5\% aplicável a algumas 
categorias concretas. Estabelece-se a obrigação para os varejistas, de aceitar a entrega voluntaria de pequenos EEE dos consumidores. Além disso, exige-se mais rigor nas inspeções aos resíduos exportados para garantir que somente os equipamentos reutilizáveis sejam enviados aos países em desenvolvimento (REVERTIA, 2010).

Um adendo à Nota do Conselho da UE, de 7 de março de 2011, compila o último texto da proposta de transição da Presidência e explica a posição das delegações. Expõe as questões pendentes e apresenta um conjunto de propostas transitórias (CE 7042/11). Uma série dessas propostas não recebe o apoio da maioria e são rejeitadas por algumas delegações. Em função dos debates, parte da proposta de transição da Presidência (adendo) sofrem modificações. À raiz do debate derivado das propostas transitórias, a Presidência conclui que a orientação geral do conjunto da proposta de remodelação da Diretiva é aceitável para a maioria das delegações (CONSEJO DE LA UNION EUROPEA, 2011).

Com entrada em vigor no dia seguinte à sua publicação (JORNAL OFICIAL DA UNIAO EUROPEIA, 2008), a revisão da Diretiva WEEE (DIRETIVA 2008/34/CE do CE e do PE sobre REEE, de 11/03/2008) suplementa a legislação geral de gestão ambiental da UE e utiliza as mesmas definições da Diretiva anterior, para resíduos e para operações gerais de gestão de resíduos. A definição de coleta inclui a segregação e o armazenamento prévios, para fins de transporte para a planta de tratamento. A nova Diretiva WEEE estabelece os requisitos de ecodesenho, de acordo com a Diretiva 2005/32/EC, com referência ao consumo de energia dos EEE, inclusive para os equipamentos que deverão ser incluídos na nova versão (COUNCIL OF THE EUROPEAN UNION, 2009).

Uma das alterações da Diretiva 2002/96/CE pela Diretiva 2008/34/CE refere-se ao Anexo II da diretiva original, que pode ser modificado para que sejam introduzidas outras tecnologias de tratamento, que garantam um nível de proteção da saúde humana e do ambiente pelo menos idêntico ao anterior. Outra alteração importante diz respeito ao estabelecimento das regras de execução necessárias para o controle do cumprimento pelos Estados-Membros dos objetivos previstos, incluindo especificações dos materiais. Essas medidas, que têm por objetivo alterar elementos não essenciais da Diretiva 
2002/96/CE, são aprovadas pelo procedimento de regulamentação com controle (EUROPA PRESS, 2008).

Com relação à adaptação ao progresso científico e tecnológico, devem ser aprovadas todas as alterações necessárias para adaptar o anexo IB (em especial com vista à possível inclusão de aparelhos de iluminação de uso doméstico, lâmpadas de incandescência e produtos fotovoltaicos), o Anexo II da Diretiva WEEE (especialmente, tendo em conta a evolução tecnológica em matéria de tratamento de REEE) e, os anexos III e IV, relativos ao progresso científico e tecnológico. Essas medidas devem abranger os resíduos de EEE que não existiam na ocasião da aprovação das Diretivas de 2002. A Comissão deve avaliar prioritariamente, pelo procedimento de regulamentação com controle, se as referências às placas de circuitos impressos para telefones celulares e às telas de cristais líquidos devem ser alteradas.

A reformulação da Diretiva 2002/95/EC (RoHS Recast, 2011), sobre a restrição do uso de certas substâncias perigosas nos EEE é publicada no Jornal Oficial da UE em dia $1^{\circ}$ de junho de 2011, estabelecendo por esse meio sua vigência (Official Journal of the European Union, on July 1, 2011). A Diretiva RoHS 2.0 (DIRECTIVE 2011/65/EU OF THE EUROPEAN PARLIAMENT AND OFTHECOUNCIL) revoga a Diretiva RoHS original, em vigor desde 2002 (CE, 2011). Os Estados Membros têm 18 meses para transpor as novas normas às legislações nacionais com data limite em 2 de janeiro de 2013. A nova Diretiva RoHS aplica-se a todos os EEE, cabos e peças de reposição. A abrangência e as exclusões de REEE, no acordo político firmado pela UE, para a nova Diretiva REEE estão descritas no Quadro 2. 
Quadro 2 - Categorias de REEE incluídas e excluídas na CE7042/11

\begin{tabular}{|c|c|}
\hline ABRANGÉNCIA & NÃO SE APLICA \\
\hline Pequenos e grandes eletrodomésticos & $\begin{array}{l}\text { Equipamentos necessários para proteger os } \\
\text { interesses essenciais de segurança dos } \\
\text { Estados membros, incluídas as armas, } \\
\text { munições e material bélico, destinados a fins } \\
\text { exclusivamente militares. } \\
\text { (exclusão diretamente acordada) }\end{array}$ \\
\hline $\begin{array}{l}\text { Equipamentos de informática e de } \\
\text { telecomunicações }\end{array}$ & $\begin{array}{l}\text { Equipamentos para fins espaciais (que serão } \\
\text { enviados ao espaço). } \\
\text { (inclusão em estudo) }\end{array}$ \\
\hline Equipamentos eletrônicos de consumo & $\begin{array}{l}\text { Equipamentos especificamente desenhados } \\
\text { para ser instalados como parte de outro tipo } \\
\text { de equipamento. } \\
\text { (exclusão diretamente acordada) }\end{array}$ \\
\hline Equipamentos de iluminação & $\begin{array}{l}\text { Grandes ferramentas e instalações } \\
\text { industriais fixas. } \\
\text { (inclusão em estudo) }\end{array}$ \\
\hline Ferramentas elétricas e eletrônicas & $\begin{array}{l}\text { Meios de transporte de pessoas ou cargas, } \\
\text { com exceção de veículos elétricos de duas } \\
\text { rodas, que não estejam homologados. } \\
\text { (inclusão em estudo) }\end{array}$ \\
\hline $\begin{array}{c}\text { Brinquedos, equipamentos de lazer e } \\
\text { para o esporte }\end{array}$ & $\begin{array}{l}\text { Máquinas móveis não destinadas a circular por } \\
\text { rodovias e de uso exclusivamente profissional. } \\
\text { (inclusão em estudo) }\end{array}$ \\
\hline Equipamentos médicos & $\begin{array}{l}\text { Dispositivos implantáveis ativos } \\
\text { (inclusão em estudo) }\end{array}$ \\
\hline $\begin{array}{l}\text { Instrumentos de controle e vigilância, } \\
\text { incluindo os de controle industrial }\end{array}$ & $\begin{array}{l}\text { Painéis fotovoltaicos. } \\
\text { (inclusão em estudo) }\end{array}$ \\
\hline Máquinas de venda automática & $\begin{array}{l}\text { Grandes instalações fixas de uso profissional } \\
\text { (inclusão em estudo) }\end{array}$ \\
\hline $\begin{array}{c}\text { Outros EEE não incluídos nas categorias } \\
\text { anteriores }\end{array}$ & $\begin{array}{l}\text { Equipamentos especificamente concebidos } \\
\text { para o único propósito de investigação e } \\
\text { desenvolvimento, e disponíveis só em um } \\
\text { âmbito interempresarial (B2B) *. } \\
\text { (inclusão em estudo) }\end{array}$ \\
\hline
\end{tabular}

Fonte: Public Consilium - Europa (2011)

*B2B= Equipamentos provenientes de pessoas jurídicas. (B2B, do inglês "Business to Business" 
A ampliação da abrangência será gradual, com previsão para estar completa até 2019. Na falta de solução satisfatória, poderá haver exceções para determinados materiais ou componentes específicos (RELEC, 2011). O rearranjo do escopo em novas categorias permite o estabelecimento de metas mais diferenciadas para coleta, reciclagem e tratamento de REEE, conforme o resumido no Quadro 3.

Quadro 3 - Metas diferenciadas de coleta, reciclagem e tratamento específico para cada categoria de tratamento de REEE.

\begin{tabular}{|c|c|c|c|}
\hline Categoria de REEE & $\begin{array}{l}\text { Metas de } \\
\text { coleta }\end{array}$ & $\begin{array}{l}\text { Metas de } \\
\text { reciclagem }\end{array}$ & $\begin{array}{l}\text { Requisitos de } \\
\text { tratamento } \\
\text { específico }\end{array}$ \\
\hline Grandes eletrodomésticos $(1 \mathrm{~A}, 10)$ & NAO & NAO & NAO \\
\hline Equipamentos de refrigeração (1B) & SIM & Talvez & SIM: CFCs \\
\hline $\begin{array}{l}\text { Pequenos eletrodomésticos: } 2 A \text {, } \\
3 A, 4 A, 6,7 \text {, (com predominância } \\
\text { de partes de plástico) }\end{array}$ & SIM & $\begin{array}{c}\text { SIM: } \\
\text { Para reciclagem } \\
\text { de plástico }\end{array}$ & $\begin{array}{c}\text { SIM: } \\
\text { NiCd da categoria } 6\end{array}$ \\
\hline $\begin{array}{l}\text { Pequenos eletrodomésticos (1C, } \\
3 \mathrm{~A}) \text {, (com predominância de partes } \\
\text { de metal) }\end{array}$ & NAO & NAO & NAO \\
\hline Equipamentos com CRT (3B, 4B) & SIM & $\begin{array}{l}\text { SIM: para vidros } \\
\text { de TRC }\end{array}$ & Controle de $\mathrm{PbO}$ \\
\hline Monitores de tela plana $(3 \mathrm{C}, 4 \mathrm{C})$ & SIM & Talvez & $\begin{array}{c}\text { SIM: para remoção de } \\
\text { Hg do LCD }\end{array}$ \\
\hline Lâmpadas de descarga de gás & SIM & $\begin{array}{l}\text { Talvez: para } \\
\text { vidro HQ (High } \\
\text { Quality) }\end{array}$ & SIM: remoção de Hg \\
\hline
\end{tabular}

Extraído de: 2008 Review of Directive 2002/96 on Waste Electrical and Electronic Equipment (ec.europa.eu/environment/waste/pdf/weee_review.pdf)

\subsubsection{Revisão da Diretiva sobre Pilhas e Acumuladores}

A Decisão da Comissão, 2009/603/CE, de 5 de agosto, estabelece requisitos para o registro de produtores de pilhas e acumuladores, de conformidade com a Diretiva 2006/66/CE do Parlamento Europeu e do Conselho e unifica os registros para a UE [notificada com o número C (2009) 6054]. Em seu Anexo, relaciona as informações que deverão ser apresentadas para o registro. 


\subsection{MARCO LEGAL NA ESPANHA}

Na Espanha, até 2006, o destino da maioria dos REEE eram os aterros, legais e clandestinos ou, os trituradores, sem nenhum tipo de tratamento prévio. Desde então, com a transposição das Diretivas Europeias WEEE e RoHS, mediante a aplicação do Real Decreto 2008/2005 e das leis impostas pelo Ministério da Indústria e respectivas Comunidades Autônomas, a situação vem mudando, na trilha da sustentabilidade econômica e ambiental liderada pela UE (GRC, 2006).

\subsubsection{Real Decreto sobre EEE e a gestão de seus resíduos}

O Real Decreto 208/2005, sobre equipamentos elétricos e eletrônicos e a gestão de seus resíduos, publicado em 25 de fevereiro de 2005 (BOE n 47, 2005), incorpora à normativa espanhola a Diretiva 2002/96/CE (WEEE) e a Diretiva 2002/95/CE (RoHS), fundindo as duas em uma só legislação. Em seu artigo três, estende as obrigações dos produtores de EEE, aos produtores de seus materiais e componentes. Além da transposição das Diretivas, o RD 208/2005 contém:

- Três Disposições adicionais (Registro, Financiamento de gestão de REEE históricos ${ }^{5}$, Prevenção de riscos laborais).

- Disposição transitória única: (Informação sobre repercussão dos custos de gestão dos REEE históricos sobre os preços dos produtos).

- Três Disposições finais (Título de competência, Desenvolvimento, aplicação e adaptação, Entrada em vigor).

Materiais elétricos como cabos e equipamentos elétricos como motores ou transformadores não são considerados REEE (UCA, 2010).

\footnotetext{
${ }^{5}$ REEE históricos são aqueles existentes antes do registro da transposição da Diretiva WEEE para a legislação nacional.
} 


\subsubsection{Real Decreto sobre Pilhas e Acumuladores}

O Real Decreto 106/2008 (ESPANHA, 2008), sobre pilhas e acumuladores e a gestão de seus resíduos, transpõe a Diretiva 2006/66/CE do Parlamento Europeu e do Conselho, limitando o teor de metais pesados (cádmio, mercúrio e chumbo). Incorpora à legislação espanhola, a Diretiva 2006/66/CE (UE, 2008) relativa a pilhas, acumuladores e aos resíduos que contenham determinadas substâncias perigosas e, dispõe sobre tratamento, reciclagem e eliminação desses resíduos e pilhas. A Diretiva 2006/66/CE faz referência tanto às pilhas e acumuladores portáteis, de consumo doméstico, como às industriais e automotivas, proibindo a colocação no mercado das que contenham quantidades de mercúrio e cádmio superiores às estabelecidas.

\subsubsection{Transposição das diretivas da UE para a legislação espanhola}

A transposição das diretivas para a legislação nacional da Espanha é realizada em etapas e, assim como nos demais países membros da UE, é acompanhada e atualizada em uma série de relatórios que registram seu progresso (PECHARDS, 2005). A partir da transposição, estabelece-se a obrigatoriedade de registro de todos os produtores de EEE cujos equipamentos sejam produzidos ou comercializados na Espanha, os quais devem se inscrever no Registro Nacional de Produtores de REEE (REI-RAEE), incorporado ao já existente Registro de Estabelecimentos Industriais (REI) (RD 697/1995). Esta ação cumpre a determinação da normativa da UE, da criação de um registro nacional de produtores em cada um dos estados membros. Com isso, pretende-se fazer um seguimento dos EEE introduzidos no mercado e o controle dos REEE coletados, reutilizados e reciclados. Com base no Princípio de Precaução e no Princípio do Poluidor Pagador (AGENDA 21, 1992), a legislação espanhola responsabiliza os produtores (fabricantes, importadores e distribuidores) pelos custos da gestão dos resíduos gerados. Essa responsabilidade leva os produtores a se unirem para organizar Sistemas Integrados de Gestão (SIG), nos quais os custos de coleta e reciclagem são rateados entre todos. Essas organizações devem ser fundações sem fins lucrativos, mas na prática disputam entre si a adesão do maior numero possível de empresas associadas. O processo de transposição não tem sido fácil, pois enfrenta muitos conflitos de interesses (ALTADILL, 2008). O Quadro 4 resume os principais pontos da transposição e os principais SIG-REEE da Espanha. 
Quadro 4 - Resumo da transposição das Diretivas WEEE e RoHS para a legislação nacional espanhola.

\begin{tabular}{|c|c|}
\hline Progresso da transposição & $\begin{array}{l}\text { Real Decreto 208/2005, adotado em fevereiro de } 2005 \text {, } \\
\text { transpõe as Diretivas RoHS e WEEE para a legislação } \\
\text { nacional. }\end{array}$ \\
\hline Datas importantes & Registro: A partir de 01/01/2006 \\
\hline Coleta de REEE B2C & $\begin{array}{l}\text { Taxa de coleta de } 1: 1 \text { em pontos de venda, sem custos para o } \\
\text { consumidor. } \\
\text { Postos de entrega voluntária da Prefeitura Local coletam REEE } \\
\text { domiciliares e de distribuidores. } \\
\text { Produtores podem criar seus próprios sistemas de coleta para } \\
\text { REEE domiciliares. }\end{array}$ \\
\hline $\begin{array}{l}\text { Financiamento da Coleta } \\
\text { B2C de REEE históricos } \\
\text { e } \\
\text { taxa visível }\end{array}$ & $\begin{array}{l}\text { Custo de coleta de acordo com participação no mercado } \\
\text { (market share). } \\
\text { Obrigatória até } 2011 \text {. (e até } 2013 \text { para categoria1). }\end{array}$ \\
\hline $\begin{array}{l}\text { Financiamento da Coleta } \\
\text { B2C de REEE novos } \\
\text { e garantia financeira }\end{array}$ & $\begin{array}{l}\text { O produtor é responsável por seu próprio REEE. } \\
\text { Somente para sistemas independentes (não SIG) }\end{array}$ \\
\hline $\begin{array}{l}\text { Responsabilidade da } \\
\text { Coleta B2B }\end{array}$ & $\begin{array}{l}\text { O produtor é responsável por coleta B2B de REEE histórico em } \\
\text { uma razão de } 1: 1 \text {. } \\
\text { O produtor é responsável por coleta B2B de REEE novos, a } \\
\text { não ser que tenha outros acordos. } \\
\text { A Administração Local pode coletar B2B, se existir um acordo } \\
\text { voluntário. }\end{array}$ \\
\hline $\begin{array}{l}\text { Registro Nacional de } \\
\text { Produtores }\end{array}$ & $\begin{array}{l}\text { Registro Nacional de Estabelecimentos Industriais (REI), mas } \\
\text { os produtores devem também ser registrados na Comunidade } \\
\text { Autônoma onde está sua sede (vigência a partir de } 1^{\circ} \text { de } \\
\text { janeiro de 2006). }\end{array}$ \\
\hline $\begin{array}{l}\text { Câmara de Compensação } \\
\text { "Clearing House" ** }\end{array}$ & Registro Nacional de Estabelecimentos Industriais. \\
\hline $\begin{array}{l}\text { Sistemas Coletivos de } \\
\text { Gestão }\end{array}$ & $\begin{array}{l}\text { AMBILAMP, ECOASIMELEC }{ }^{*} \text { ECOLEC, ECOLUM, ECO- } \\
\text { RAEE's, ECOTIC, ERP }\end{array}$ \\
\hline
\end{tabular}

Elaborado pela autora com base em: PECHARDS, 2005

*A ECOASIMELEC incorpora os SIG: ECOFIMATICA, TRAGAMÓVIL e ECOPILAS.

** Clearing House:- Órgão Central fundado por produtores, os quais têm responsabilidade financeira de garantir o funcionamento dos SIG, de acordo com a Diretiva WEEE.

$B 2 B=$ Business to Business (entre pessoas jurídicas) $\quad B 2 C=$ Business to Consumer (Pessoa jurídica ao consumidor) 


\subsubsection{A experiência da aplicação do RD 208/2005 na Espanha}

O cenário da reciclagem de REEE na Espanha tem sofrido modificações, em função das exigências, tanto de recuperação como de separação dos componentes perigosos, que obrigam ao estabelecimento de novos processos, para alcançar os objetivos do RD 208/2005. Os produtores se reúnem em associações para criar seus próprios sistemas integrados de gestão (SIG) e podem cumprir suas obrigações, participando de um ou vários SIG, em colaboração com outros agentes econômicos, autorizados pelas Comunidades Autônomas (C. A.). Os gestores finais, homologados pelos SIG para o tratamento final de REEE, cobrem parte dessas exigências, com a segregação e tratamento dos componentes perigosos e o encaminhamento de outros materiais para outras empresas de recuperação de materiais (sucateiros), como plástico, vidro, sucatas de metais, etc. (RECUPERA, 2008).

A gestão ambiental dos REEE domiciliares na Espanha é financiada pelos produtores, a partir dos "puntos limpios" (pontos de entrega voluntária) e coordenada por uma Plataforma Informática de Coordenação Logística para a Gestão dos REEE provenientes dos "Puntos Limpios" municipais, a OfiRaee. Os objetivos da Plataforma são a otimização de recursos, a homogeneização de informações, a facilidade de faturamento das administrações locais aos SIG e a eficácia na resolução de pendências. A organização atua como ponto de convergência e coordenação diversos atores da reciclagem de REEE domiciliares, entre os quais estão os SIG autorizados, as entidades locais e os “Puntos Limpios” (OfiRaee, 2011).

A incorporação do Registro de Produtores de REEE no Registro Nacional de Estabelecimentos Industriais (REI-RAEE), com a exigência da declaração trimestral dos EEE postos no mercado, facilita o estabelecimento da quota de responsabilidade de cada SIG sobre os resíduos históricos, pois a responsabilidade sobre o os REEE novos já esta estabelecida. Cada produtor é responsável por todos os seus EEE colocados no mercado conforme a Diretiva WEEE. Entretanto, a criação de um registro nacional de produtores não impede a proliferação de agentes que atuam por conta própria (freerider), sem a devida fiscalização das autoridades competentes. A relação, às vezes difíceis, das autoridades autonômicas com alguns produtores, leva a resultados ambientais nem sempre garantidos. A situação requer o estabelecimento de parâmetros válidos em todo o país e a harmonização de alguns aspectos, nos convênios firmados 
entre as Comunidades Autônomas e os SIG, além de maior coordenação entre o Ministério de Meio Ambiente e as Comunidades Autônomas (RELEC 10, 2010).

Estima-se que, dos custos anuais de gestão de REEE na Espanha, 75\% correspondem à coleta e, o restante é distribuído entre recuperação, reutilização e reciclagem. Por este motivo, inclui-se no preço final do produto ao consumidor, uma taxa de reciclagem, que equivale a um aumento de $1 \%$ no preço da maioria dos produtos e de 2 a $3 \%$ no caso dos equipamentos de refrigeração, televisores e monitores de vídeo (ALTADILL, 2008). Porem, nem sempre a determinação de "taxa visível” imposta pelo RD 208/2005 aparece discriminada no preço final ao consumidor (RELEC 10, 2010).

$\mathrm{Na}$ Espanha, apesar dos esforços por parte dos responsáveis, no sentido de conscientizar usuários e distribuidores sobre os procedimentos corretos para o descarte de REEE, diversos estudos indicam que seguem existindo fluxos paralelos e, que o sistema de gestão desses resíduos apresenta muitas falhas na cadeia de coleta, transporte e rastreabilidade dos mesmos. O país conta com modernas e suficientes plantas de tratamento autorizadas por suas Comunidades Autônomas, com capacidade para reciclar uma quantidade muito maior do que a que atualmente chega às plantas de tratamento autorizadas. Os resultados apontam para a necessidade de se incrementar o controle e a inspeção de todas as etapas do processo de gestão de REEE, principalmente para tentar evitar sua exportação ilegal (RODRIGUEZ, 2010).

A aplicação do Real Decreto sobre REEE tem sido um desafio para o setor e para as autoridades ambientais. O processo é complexo e tem enfrentado muitas dificuldades, principalmente em função da falta de clareza de sua abrangência sobre a grande diversidade de produtos e resíduos, além de supor um compromisso dos produtores, através do princípio de responsabilidade estendida do produtor (REP), ainda não totalmente entendido e assumido por esses (MARM, 2010).

O conceito de REP baseia-se na promoção do melhoramento total do ciclo de vida do produto, em todas suas fases, mediante a extensão das responsabilidades do produtor, especialmente ao devolver, recuperar e dispor esse produto. (LINDQUIST, 2003). Esse princípio articula-se com o conceito de responsabilidade individual do produtor (RIP), que determina que cada empresa seja responsável individualmente por seus produtos. A proposta consiste em incentivar financeiramente as empresas para que 
invistam na eliminação das substâncias perigosas de seus produtos e na utilização de materiais e desenhos que favoreçam a reciclagem e reutilização dos mesmos. (RETS, 2009). Na Espanha, essa responsabilidade está orientada para a cobrança de uma taxa (visível somente no caso dos REEE históricos ${ }^{6}$ ) ou para um financiamento internalizado no preço do produto, sem que se conheça sua implicação na prevenção e no desenho (RELEC, 2010).

\subsubsection{Revisão do Real Decreto 208/2005}

A implementação do Real Decreto - RD 208/2005 (ESPANHA, 2005), que transpõe as Diretivas WEEE e RoHS para a legislação nacional espanhola ainda está incompleta, mas o processo de revisão já está em curso e deverá se adaptar às mudanças determinadas na revisão das Diretivas WEEE e RoHS da UE. O RD 367/2010 (ESPANHA, 2010) sobre "sobre o livre acesso às atividades de serviços e seu exercício" modifica alguns artigos do RD 208/2005 de REEE. Entre as principais alterações estão:

- objeto e âmbito de aplicação, no qual explicita a aplicação da normativa específica sobre gestão de resíduos e a definição de produtor;

- requisitos técnicos para instalações de coleta, armazenamento temporário e tratamento (adaptação para a Diretiva de Serviços), segundo a normativa local.

- inscrição pelo referido órgão, no Registro de Produção e Gestão de Resíduos, previsto na Ley de Residuos 10/1998 (BOE n.96, 1998).

- disposição transitória única: informação aos usuários sobre a repercussão dos custos da gestão de resíduos históricos no preço do produto (taxa visível).

Além disso, o RD 3R67/10 estabelece multas por infração de incorreta transposição das Diretivas WEEE e RoHS, para a legislação nacional espanhola (não conformidade).

\footnotetext{
${ }^{6}$ REEE históricos são aqueles já existentes antes da transposição das Diretivas WEEE e RoSH da UE para a legislação nacional.
} 


\subsubsection{Revisão do Real Decreto sobre Pilhas e Acumuladores}

O Real Decreto 943/2010 (ESPANHA, 2010), sobre pilhas e acumuladores e a gestão ambiental de seus resíduos modifica o RD 106/2008 (ESPANHA, 2008) e transpõe a diretiva da UE sobre estes produtos. Entre outras providencias, essa nova normativa elimina a obrigação de identificar as pilhas e baterias com o símbolo de seu SIG, desobriga os produtores de declarar ou de financiar a gestão dos resíduos das pilhas que enviem anualmente ao exterior e autoriza que as pilhas colocadas à venda antes de setembro de 2008sigam no mercado (antes do RD 106/2008). Os produtores serão responsáveis pela coleta e gestão das mesmas quantidades e tipos de pilhas, acumuladores e baterias que tenha colocado à venda em território espanhol e, poderão fazê-lo através de um sistema de depósito, devolução e retorno, através de um SIG, ou através de um sistema público (BOE 189/2010).

\subsubsection{Sistemas Integrados de Gestão de REEE na Espanha}

A Diretiva EU 96/2002 da UE e o Real Decreto que a transpõe para a legislação espanhola entendem que a responsabilidade social sobre o meio ambiente é de todos os cidadãos, mas que a responsabilidade principal sobre os REEE recai sobre o produtor. Para fazer frente a essa obrigação, os produtores (fabricantes e importadores) têm a possibilidade de se associar criando entidades sem fim lucrativo que se responsabilizem pela correta gestão dos produtos colocados no mercado, ao final de sua vida útil (REVERTIA, 2010). Na Espanha, essas entidades denominam-se Sistemas Integrados de Gestão (SIG) e estão representadas no Quadro 3, como Sistemas Coletivos de Gestão. Os principais SIG de REEE na Espanha, em nível nacional são: AMBILAMP, ECOASIMELEC (que inclui ECOFIMATICA, TRAGAMOVIL e ECOPILAS), ECOLEC, ECOLUM, ECO-RAEE's, ECOTIC e ERP. 


\subsection{MARCO LEGAL NO BRASIL}

No Brasil, a discussão sobre os REEE ainda é incipiente e, na melhor das hipóteses, esses resíduos são descartados junto com o resíduo sólido urbano (RSU) e encaminhados a aterros sanitários, aterros controlados e outros destinos não adequados. O problema se acentua, em função do risco das substâncias tóxicas serem liberadas em aterros clandestinos ou lixões, que funcionam em condições precárias, em solo sem impermeabilização e a céu aberto, próximos de corpos d'água e de áreas residenciais (ZANCHETTA, 2008). Outro problema a ser considerado é o dos produtos que entram sem controle no país, apresentando altos teores de contaminantes. Esses produtos acabam se tornando "resíduos órfãos", sem nenhum responsável por sua destinação (ABINEE, 2011).

\subsubsection{Política Nacional de Resíduos Sólidos}

No âmbito Federal, após quase duas décadas como projeto de lei, foi aprovada pela Presidência da República do Brasil, a Lei Federal N 12.305 (BRASIL, 2010 a), que institui a Política Nacional de Resíduos Sólidos (PNRS). Dispõe sobre seus princípios, objetivos, instrumentos e sobre as diretrizes relativas à gestão integrada e ao gerenciamento de resíduos sólidos, incluindo-se os perigosos e os REEE, às responsabilidades dos geradores e do poder público e aos instrumentos econômicos aplicáveis. Estão sujeitas à observância desta Lei as pessoas físicas ou jurídicas.

A PNRS propõe a responsabilidade compartilhada pelo ciclo de vida dos produtos, como o conjunto de atribuições individualizadas e encadeadas dos fabricantes, importadores, distribuidores e comerciantes, dos consumidores e dos titulares dos serviços públicos de limpeza urbana e manejo dos resíduos sólidos, pela minimização do volume de resíduos sólidos e rejeitos gerados, bem como pela redução dos impactos causados à saúde humana e à qualidade ambiental decorrentes do ciclo de vida dos produtos (JACOBI e BESEN, 2011). Dentro dessa estrutura de gestão de resíduos todos os atores têm responsabilidades específicas e igualmente relevantes, mas não solidárias. O não cumprimento de responsabilidades por uma das partes não implica na obrigação das outras partes em cumpri-las. 
A falta de estrutura pode representar um entrave na política de gestão prevista na PNRS. Não se pode ignorar que a cultura de gestão de resíduos no Brasil é praticamente nula. Portanto, o planejamento de política pública é o ponto inicial para qualquer medida que pretenda ser eficaz nesta área. A PNRS prevê uma série de Planos Setoriais de Resíduos. A ideia básica desse sistema de planejamento setorial é formar uma rede harmônica e articulada de gestão de resíduos em todo o território brasileiro, mas falta a definição metas e de instrumentos para cumpri-las. Sem dúvida, as infraestruturas necessárias para uma eficiente logística reversa de REEE dependem, sobretudo, de uma elaboração cuidadosa dos Planos Setoriais de Resíduos, previstos no art. 14 da PNRS. Esses planos deverão orientar a implementação da gestão integrada dos resíduos, e, consequentemente, das responsabilidades diferenciadas de cada interveniente.

O Decreto Federal No 7.404/2010, regulamenta a Lei Federal № 12.305/2010, que institui a PNRS e criou o Comitê Interministerial da Política Nacional de Resíduos Sólidos e o Comitê Orientador para a Implantação dos Sistemas de Logística Reversa (BRASIL, 2010 b). Este decreto decide como se dará a implementação das exigências da PNRS e as sanções para quem não cumpri-las. Os fabricantes, importadores, distribuidores, comerciantes, consumidores e serviços públicos de limpeza urbana e de manejo de resíduos sólidos são responsáveis pela logística reversa do produto, que poderá ser implantada por decreto. O limite estabelecido para sua entrada em vigor é em agosto de 2014, mas já existem alguns acordos setoriais nesse sentido. As metas poderão ser fixadas com base em critérios quantitativos, qualitativos ou regionais.

Na gestão e gerenciamento de resíduos sólidos, deverá ser observada a seguinte ordem de prioridade, denominada hierarquia de resíduos: não geração, redução, reutilização, reciclagem, tratamento dos resíduos sólidos e disposição final ambientalmente adequada dos rejeitos. Os geradores de resíduos sólidos deverão adotar medidas que promovam a redução da geração dos resíduos, principalmente os resíduos perigosos, na forma prevista nos respectivos planos de resíduos sólidos e nas demais normas aplicáveis. As pessoas jurídicas que operam com resíduos perigosos, em qualquer fase do seu gerenciamento, deverão elaborar um plano de gerenciamento de resíduos perigosos e submetê-lo ao órgão ambiental competente. Esse plano poderá ser inserido no plano de gerenciamento de resíduos sólidos. 


\subsubsection{A Política Nacional de Resíduos Sólidos e os REEE}

A Lei $\mathrm{N}^{\circ} 12.305 / 2010$, que institui a PNRS, estabelece responsabilidades e determina que, são obrigados a estruturar e implementar sistemas de logística reversa, mediante retorno dos produtos após o uso pelo consumidor, de forma independente do serviço público de limpeza urbana e de manejo dos resíduos sólidos, os fabricantes, importadores, distribuidores e comerciantes de pilhas e baterias, lâmpadas fluorescentes, de vapor de sódio e mercúrio e de luz mista, produtos eletroeletrônicos e seus componentes.

Os consumidores deverão efetuar a devolução após o uso, aos comerciantes ou distribuidores, dos produtos acima referidos. Porém, a lei não explica como exigir que o consumidor cumpra sua parte. Os comerciantes e distribuidores deverão efetuar a devolução aos fabricantes ou aos importadores dos produtos. Os fabricantes e os importadores darão destinação ambientalmente adequada aos produtos e às embalagens reunidos ou devolvidos, sendo o rejeito encaminhado para a disposição final ambientalmente adequada, na forma estabelecida pelo órgão competente e, se houver, pelo plano municipal de gestão integrada de resíduos sólidos. A logística reversa relativa às lâmpadas e aos EEE será implementada progressivamente segundo cronograma estabelecido em regulamento.

\subsubsection{Resolução CONAMA $N^{\circ} 401 / 2008$ sobre pilhas e baterias}

A Resolução CONAMA No 401/2008 (BRASIL, 2008) estabelece novos limites máximos de chumbo (traços de até $0,1 \%$ em peso), cádmio (até $0,002 \%$ em peso) e mercúrio (até $0,0005 \%$ em peso) para pilhas e baterias comercializadas no território nacional e os critérios e padrões para o seu gerenciamento ambientalmente adequado. Esta norma revoga a Resolução 257/99, alterada pela Resolução CONAMA 263/99 Outros metais, como cobre, zinco, manganês, níquel e lítio, embora considerados perigosos para a saúde humana, não são contemplados nesta legislação (CÂMARA e AFONSO, 2011). Esta Resolução determina o prazo de dois anos para que todos os pontos de venda de pilhas e baterias disponibilizem postos de coletas aos consumidores, para receber esses produtos no fím de sua vida útil. Caberá ao comércio varejista, encaminhar o material recolhido aos fabricantes e importadores que, por sua vez, serão responsáveis pela reciclagem ou pela disposição final em aterros licenciados. As 
advertências sobre os riscos à saúde e ao meio ambiente, bem como informações ao consumidor sobre os procedimentos corretos deverão constar de forma clara e visível nas embalagens e materiais publicitários (BRASIL, 2008).

\subsubsection{Descarte de lâmpadas fluorescentes}

A carência de informação e de fiscalização sobre o descarte incorreto de resíduos gerados por tubos e lâmpadas fluorescentes pode resultar em contaminação ambiental e colocar em risco a saúde da população. Esses produtos contêm metais pesados, entre os quais o mercúrio, altamente tóxico para todos os tipos de vida. $\mathrm{O}$ gerenciamento desses resíduos deve incluir sua coleta seletiva, armazenamento e reciclagem. No Brasil, a baixa taxa de reciclagem, apenas $6 \%$ do volume total do produto descartado (DURAO Jr e WINDMÖLLER, 2011), pode ser consequência do custo elevado de reciclagem e da dificuldade de logística reversa desses produtos.

A falta de lei nacional não exime de responsabilidade os fabricantes. No que se refere ao descarte adequado das lâmpadas fluorescentes tubulares e compactas, a PNRS (BRASIL, 2010) traz avanços importantes. Determina, por exemplo, que a coleta, descontaminação e reciclagem desse tipo de produto passarão a ser obrigatórios no Brasil a partir do segundo semestre de 2012, em função da presença de mercúrio e outros metais pesados em sua composição.

Para se chegar ao melhor modelo de logística reversa para lâmpadas e tubos fluorescentes foi formado em torno do Conselho Nacional do Meio Ambiente (CONAMA) o Grupo de Trabalho sobre a Disposição Final para Resíduos de Lâmpadas Mercuriais. Composto por representantes da indústria, importadores, lojistas, órgãos governamentais, laboratórios de pesquisas e entidades ligadas à defesa do consumidor, o grupo se transformou no principal fórum de discussões para se tratar do assunto.

Existem também leis estaduais e municipais que tratam especificamente sobre o tema. Em São Paulo, por exemplo, a Lei da Política Estadual de Resíduos Sólidos do

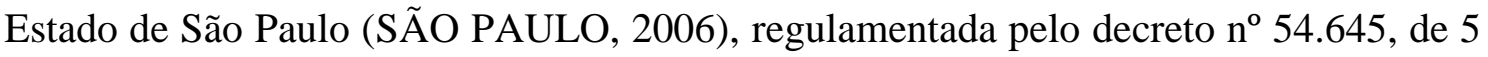
de agosto de 2009, responsabiliza o fabricante, distribuidor e importador do produto, que geram resíduos de significativo impacto ambiental mesmo pós-consumo, da eliminação, recolhimento, tratamento e disposição final dos mesmos. 
Apesar do que determina a legislação, na maioria das vezes, a responsabilidade pelo descarte indevido das lâmpadas recai sobre o gerador. Porém, quando se trata de dano ambiental a responsabilidade civil é objetiva. O poluidor é obrigado, independentemente da existência de culpa, a indenizar ou reparar os danos causados ao meio ambiente e a terceiros, afetados por sua atividade. O Ministério Público da União e dos Estados terá legitimidade para propor ação de responsabilidade civil e criminal, por danos causados ao meio ambiente. (BRASIL, 1981). Portanto, o consumidor - pessoa física ou jurídica que descartar de forma indevida esses resíduos - é também responsável solidário pelos danos ambientais decorrentes da contaminação. Tendo em vista o gás tóxico das lâmpadas, os consumidores, caso não cumpram com as exigências estabelecidas por lei, podem responder por crime de poluição, conforme o Código Penal e a Lei Federal 9.605/1998 sobre Crimes Ambientais (BRASIL, 1998).

\subsubsection{Marco legal no Estado de São Paulo}

A falta de legislação nacional não exime de responsabilidade os fabricantes. Há leis estaduais e municipais que tratam especificamente sobre o tema. Em São Paulo, a Lei Estadual no 10.888 (SÃO PAULO, 2001 a) dispõe sobre o descarte final de produtos potencialmente perigosos do resíduo urbano que contenham metais pesados, pilhas, baterias, lâmpadas fluorescentes e responsabiliza o fabricante pela descontaminação e pela destinação final das lâmpadas fluorescentes.

A Lei da Política Estadual de Resíduos Sólidos (PERS) do Estado de São Paulo, instituída pela Lei Estadual $n^{\circ} 12.300$ (SÃO PAULO, 2006), regulamentada pelo Decreto Estadual no 54.645, (SÃO PAULO, 2009), responsabiliza os produtores do produto, que geram resíduos de significativo impacto ambiental pós-consumo. Na PERS de SP, a indústria de material elétrico, eletrônico e de comunicação é referida como um dos setores produtivos considerados, com a obrigação de gerenciar seus resíduos, com a elaboração dos respectivos Planos de Gerenciamento, as gradações de metas estabelecidas pelas suas associações representativas setoriais e pelo órgão ambiental.

Publicada no Diário Oficial do Estado de São Paulo em 07 de julho de 2009, a Lei $\mathrm{n}^{\mathrm{o}} 13.576 / 2009$, institui normas e procedimentos para a reciclagem, gerenciamento e destinação final de lixo tecnológico. Por esta lei, os produtos e os componentes eletroeletrônicos considerados resíduos tecnológicos devem receber destinação final 
adequada que não provoque danos ou impactos negativos ao meio ambiente e à sociedade. A responsabilidade pela destinação final é solidária entre as empresas que produzam, comercializem ou importem produtos e componentes eletroeletrônicos (FIESP, 2009).

O Decreto Estadual $n^{\circ}$ 54.645/2009 regulamenta a Lei Estadual $N^{\circ} 12.300 / 2006$ e determina que os fabricantes, distribuidores ou importadores de produtos que, por suas características, venham a gerar resíduos sólidos de significativo impacto ambiental, mesmo após o consumo desses produtos, fiquem responsáveis pelo atendimento das exigências estabelecidas pelos órgãos ambientais e de saúde, especialmente para fins de eliminação, recolhimento, tratamento e disposição final desses resíduos, bem como para a mitigação dos efeitos nocivos que causem ao meio ambiente ou à saúde pública (SÃO PAULO, 2009).

Em vigor desde o dia 31 de março de 2010, a Resolução SMA 024, complementa o disposto no Artigo 19, parágrafo único, do Decreto Estadual $\mathrm{n}^{\circ}$ $54.645 / 2009$ e torna pública a relação dos produtos que, por suas características, venham a gerar resíduos sólidos de significativo impacto ambiental (SÃO PAULO, 2010). Entre os produtos relacionados como ambientalmente impactantes, estão as lâmpadas florescentes, as baterias automotivas e os produtos eletroeletrônicos.

De acordo com a Resolução SMA 24, os fabricantes e distribuidores ou importadores dos produtos relacionados ficam obrigados a: i) manter, individualmente ou sob a forma de parcerias, postos de entrega voluntária (PEV) para resíduos pósconsumo; ii) orientar os consumidores quanto à necessidade de devolução dos resíduos pós-consumo; iii) cumprir metas de recolhimento; iv) declarar a quantidades desses resíduos produzidos; v) Encaminhar os resíduos recolhidos para reciclagem, recuperação energética, reutilização ou outra destinação permitida pela Companhia Ambiental do Estado de São Paulo (CETESB).

O estabelecimento das metas de recolhimento deverá considerar, no mínimo, a implantação da coleta seletiva nos municípios paulistas, a capacidade nominal instalada para beneficiamento e transformação dos resíduos recicláveis, o Relatório de Qualidade Ambiental e o Painel de Indicadores Ambientais, publicados anualmente pela Secretaria do Meio Ambiente. 
A Lei Estadual No 14.470/2011, publicada no Diário Oficial do Estado de São Paulo de 22 de junho, dispõe sobre separação dos resíduos recicláveis descartados pelos órgãos e entidades da administração pública estadual na fonte geradora. Esses resíduos poderão ser destinados a associações e cooperativas de catadores de materiais recicláveis (coleta seletiva solidária), no âmbito de programas de incentivo a essas entidades, quando habilitadas de acordo com os requisitos estabelecidos (SÃO PAULO, 2011 a).

A Secretaria do Meio Ambiente de São Paulo determinou, por meio de sua resolução no. 131 (SÃO PAULO, 2010) e, de acordo com a Política Nacional de Resíduos Sólidos, que: "ficam obrigados os fabricantes, distribuidores e importadores de produtos eletro-eletrônicos e lâmpadas fluorescentes (entre outros produtos especiais) a: i) manter, individualmente ou sob a forma de parcerias, postos de entrega voluntária para os resíduos pós-consumo; ii) Orientar os consumidores quanto à necessidade de devolução dos resíduos pós-consumo; iii) Cumprir as metas estruturais e finais de recolhimento; iv) os resíduos recolhidos deverão ser encaminhados para reciclagem, recuperação energética, reutilização ou outra destinação permitida pela Companhia Ambiental do Estado de São Paulo - CETESB”. As metas estruturais são graduais e deverão ser implementadas ate 31 de março deverão ser estabelecidas pela Comissão Estadual de Gestão de Resíduos Sólidos até 31 de março de março de 2014.

\subsubsection{Os REEE no Município de São Paulo}

O Município de São Paulo ainda não possui uma lei especifica sobre REEE, mas existem alguns projetos de lei sobre o tema e a PMSP adota medidas para a regulamentação gradativa dessa questão, por meio de emendas à legislação municipal já existente sobre resíduos, conforme o resumido a seguir:

PROJETO DE LEI MUNICIPAL N $\mathbf{N}^{\mathbf{5} 75 / 2009}$ (Ementa): Dispõe sobre a obrigatoriedade de coleta e destinação final ambientalmente adequada, após sua vida útil, considerados resíduos urbanos e caracterizados como lixo eletrônico e tecnológico (SÃO PAULO, 2009). 


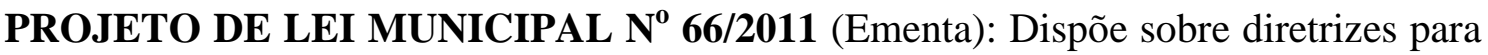
a instituição do Programa de Coleta Seletiva Contínua dos Resíduos Eletrônicos e Tecnológicos (SÃO PAULO, 2011).

A legislação brasileira sobre o tema de REEE, em todas as esferas de governo, ainda está em processo de construção e necessita ser formulada de modo mais específico. Sua eficácia vai depender do estabelecimento de regras claras e de fiscalização sistemática. Na prática as medidas ainda são mitigadoras, quando deveriam ser pró-ativas. Cresce entre legisladores, especialistas e produtores, o debate em torno da logística reversa e da responsabilidade compartilhada, mas observa-se uma tendência de copiar a Diretiva WEEE de 1992, da União Europeia, quando esta já está em processo avançado de revisão de sua legislação. O Brasil, como potência emergente no cenário da economia mundial, reúne condições para estabelecer regras de mercado. A experiência de uma década de implantação das diretivas WEEE e RoHS, ensina o que não fazer. A revisão das diretivas da EU podem ser tomadas como ponto de partida para formular uma legislação eficaz e de melhor qualidade. 


\section{RESULTADOS E DISCUSSÃO}

O levantamento de dados censitários realizado no Sistema de Informação da Administração Patrimonial (SIAP) - MERCURIO, para localização do registro de todos os bens patrimoniais das unidades do QS/D-USP que sofreram processo de baixa entre 1999 a 2009, indicou que não há nenhum registro sobre seu destino. Após os procedimentos de baixa patrimonial, esses bens adquirem o status de bens inservíveis (GEFIN, 2004). Finalizados os procedimentos patrimoniais, os processos são encaminhados à Contabilidade da Unidade e, para fins administrativos, esses bens deixam de existir. Diferentemente do que vem ocorrendo em IES dos Estados Unidos, onde os EEE em final de vida útil são leiloados ou vendidos para empresas recicladoras (BABBIT, 2011) ou, da UE, onde esses bens baixados são enviados a gestores externos, para tratamento e disposição final, de acordo com a Diretiva WEEE, no QS/D da USP não se conhece o fluxo dos REEE, após sua baixa no sistema. Geralmente, utilizam-se procedimentos como doação a instituições sem fins lucrativos, leilão ou apoio a programas de inclusão digital para comunidades carentes, que podem ser formas de repassar o problema sem efetivamente resolvê-lo. Entre esse material pode haver resíduos perigosos, como alguns tipos de REEE, que deveriam ser destinados de maneira segura e com autorização do órgão ambiental competente. Por este motivo, essa alternativa de destino pode ser uma forma pouco cuidadosa de se desfazer do problema, ainda que a intenção seja das melhores.

\subsection{GERAÇÃO DE REEE NO CAMPUS QS/D DA USP}

O Sistema MERCURIO, utilizado para administrar o patrimônio da USP, contem informações importantes para subsidiar a gestão de REEE. Por outro lado, apresenta dados supérfluos, sem utilidade prática para esta pesquisa. Deparou-se com a necessidade de filtrar os dados de interesse e criar uma nova base de dados para estimar o volume em peso e caracterizar os tipos de REEE gerados nas unidades do Campus 
QS/D, no período estudado. A análise das variáveis consideradas levou aos seguintes resultados:

\subsubsection{Distribuição dos bens baixados do Campus QS/D da USP por unidade}

O levantamento de todos os bens patrimoniados das unidades que compõem o Campus QS/D, realizado no SIAP, mostrou que foram baixados no período de 1999 a 2009, um total de 7.781 itens, distribuídos segundo o indicado no Gráfico 1.

Gráfico 1 - Participação percentual de bens baixados por unidade do

Campus QSD da USP (\%) (1999 - 2009)

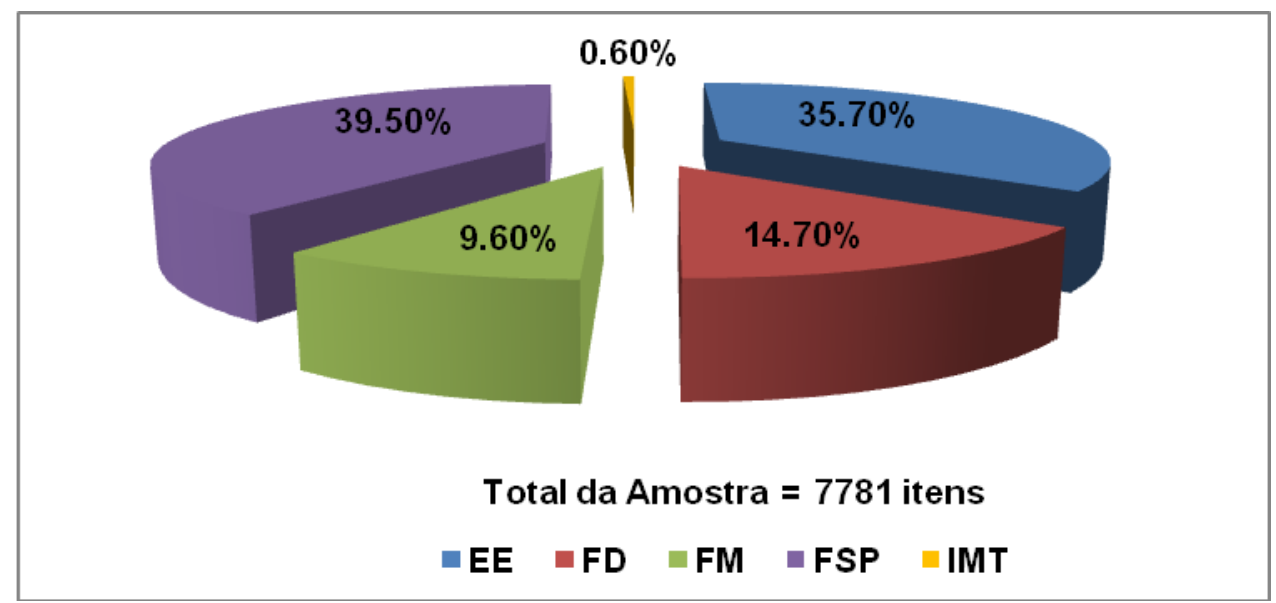

A análise estatística desses dados indica que a distribuição de baixas de bens patrimoniais nas unidades do QS/D não é proporcional à distribuição de recursos físicos e financeiros, ou à população de cada unidade, detalhados na Tabela 1.

Tabela 1 - Indicadores numéricos USP - Campus QS/D, em 2010.

UNID.

\begin{tabular}{l|rr|r|r|rr|r} 
UNID. & \multicolumn{7}{|c}{ RECURSOS } \\
\hline & \multicolumn{1}{|l|}{ Humanos } & Físicos & Financeiros & Alunos Cadastrados & $\begin{array}{l}\text { População } \\
\text { Total }\end{array}$ \\
\hline QS/D & \multicolumn{1}{|l}{$\begin{array}{l}\text { *oc. } \\
\text { N/Doc. }\end{array}$} & $\begin{array}{l}\text { Área } \\
\text { constr. } \\
\mathbf{m}^{2}\end{array}$ & $\begin{array}{l}\text { Orçamento } \\
\text { Executado } \\
\text { R\$ }\end{array}$ & Grad. PosGrad. & Serv + Alunos \\
\hline EE & 83 & 136 & 9.459 & 35.352 .345 & 465 & 489 & $\mathbf{1 . 1 7 3}$ \\
\hline FD & 166 & 185 & 25.146 & 36.020 .330 & 2.439 & 1.173 & $\mathbf{3 . 9 6 3}$ \\
\hline FM & 351 & 555 & 44.710 & 108.937 .682 & 1.408 & 2.062 & $\mathbf{4 . 3 7 6}$ \\
\hline FSP & 96 & 325 & 19.401 & 59.642 .545 & 400 & 627 & $\mathbf{1 . 4 4 8}$ \\
\hline IMT & 2 & 59 & 2.394 & 6.133 .984 & - & 42 & $\mathbf{1 0 3}$ \\
\hline TOTAL & $\mathbf{6 9 8}$ & $\mathbf{1 . 2 6 0}$ & $\mathbf{1 0 1 1 1 0}$ & $\mathbf{2 4 6 . 0 8 6 . 8 8 6}$ & $\mathbf{4 . 7 1 2}$ & $\mathbf{4 . 3 9 3}$ & $\mathbf{1 1 . 0 6 3}$
\end{tabular}

Elaborada pela autora com base em: Informações Demográficas - USP, 2011.

*Doc $=n^{o}$ de docentes $\quad N / D o c=n^{o}$ de não docentes Serv $=n^{\circ}$ de servidores 
Este resultado pode depender, entre outros fatores, da quantidade de projetos com equipamentos financiados por outras instituições (bens de terceiros e comodato), da maneira como o patrimônio é administrado e dos critérios utilizados em cada unidade, para decidir sobre a necessidade de se incorporar um item ao patrimônio, conforme o conceito de Administração Patrimonial aplicado (ANEXO II).

\subsubsection{Distribuição dos REEE baixados do Campus QS/D da USP por unidade}

Do total de bens baixados do Campus QS/D da USP entre 1999 e 2009, 3.549 itens, $(46 \%)$ foram classificados como REEE. O restante consiste de mobiliário (4.118 itens) e alguns bens (14 itens) foram classificados como "outros", por insuficiência de informação para ser considerados REEE. Os materiais de consumo (equipamentos de iluminação, teclados, mouses, fontes, baterias, ferramentas elétricas e eletrônicas, componentes e peças de reposição, entre outros) não são bens passíveis de incorporação (COMPATRIM, USP, 2010) e, portanto, não são registrados no SIAP. Os REEE provenientes desses materiais são considerados sucata e suas baixas não constam no sistema. Considerando-se apenas os REEE baixados no mesmo período, permanece a desproporcionalidade entre o número de baixas no período investigado e os indicadores numéricos das unidades do QS/D, de acordo com o representado no Gráfico 2.

Gráfico 2 - Participação percentual de REEE baixados por unidade do Campus QS/D da USP (1999 a 2009)

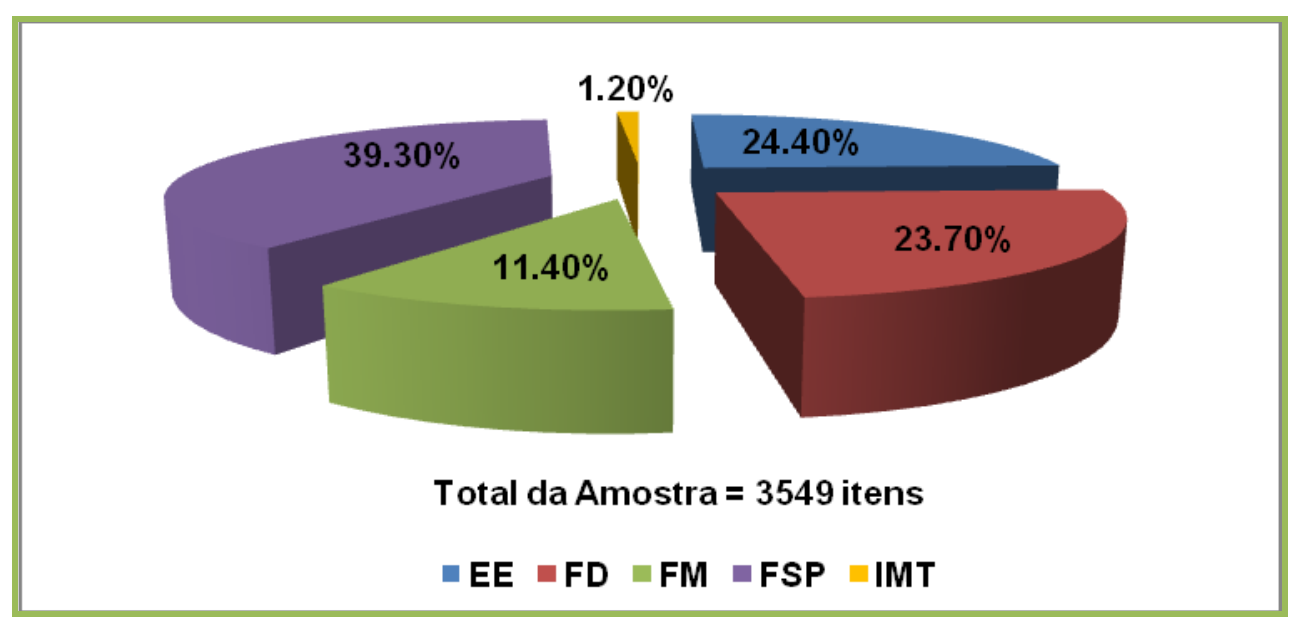

Por outro lado, este resultado mostra que, no período investigado, a participação percentual de REEE baixados do patrimônio do QS/D em cada unidade, é diretamente proporcional ao número total de baixas no mesmo período, conforme mostra a Tabela 2. 
Tabela 2 - Comparativa entre a participação percentual do total de bens baixados e a participação percentual do total de REEE por unidade do Campus do QS/D

$(1999-2009)$

\begin{tabular}{lcc}
\hline UNIDADE & Total de itens baixados (\%) & Total de REEE baixados (\%) \\
\hline IMT & 0,60 & 1,20 \\
\hline FM & 9,60 & 11,40 \\
\hline FD & 14,70 & 23,70 \\
\hline EE & 35,70 & 24,40 \\
\hline FSP & 39,50 & 39,30 \\
\hline
\end{tabular}

Estes resultados sugerem a necessidade de análise de dados complementares, para explicar a disparidade entre os indicadores numéricos das unidades do Campus do QS/D da USP e o número de itens baixados do Sistema, em cada uma delas, além dos motivos explicitados no item anterior.

\subsubsection{Evolução da geração de REEE no Campus do QS/D da USP por ano}

Os resultados indicam que a evolução anual das baixas de REEE no Campus QS/D, desde o início dos registros de baixas no Sistema MERCURIO (período entre 1999 e 2009) não corresponde a um crescimento linear, conforme mostra o Gráfico 3.

Gráfico 3 - Distribuição de REEE baixados do QS/D por ano (1999 - 2009)

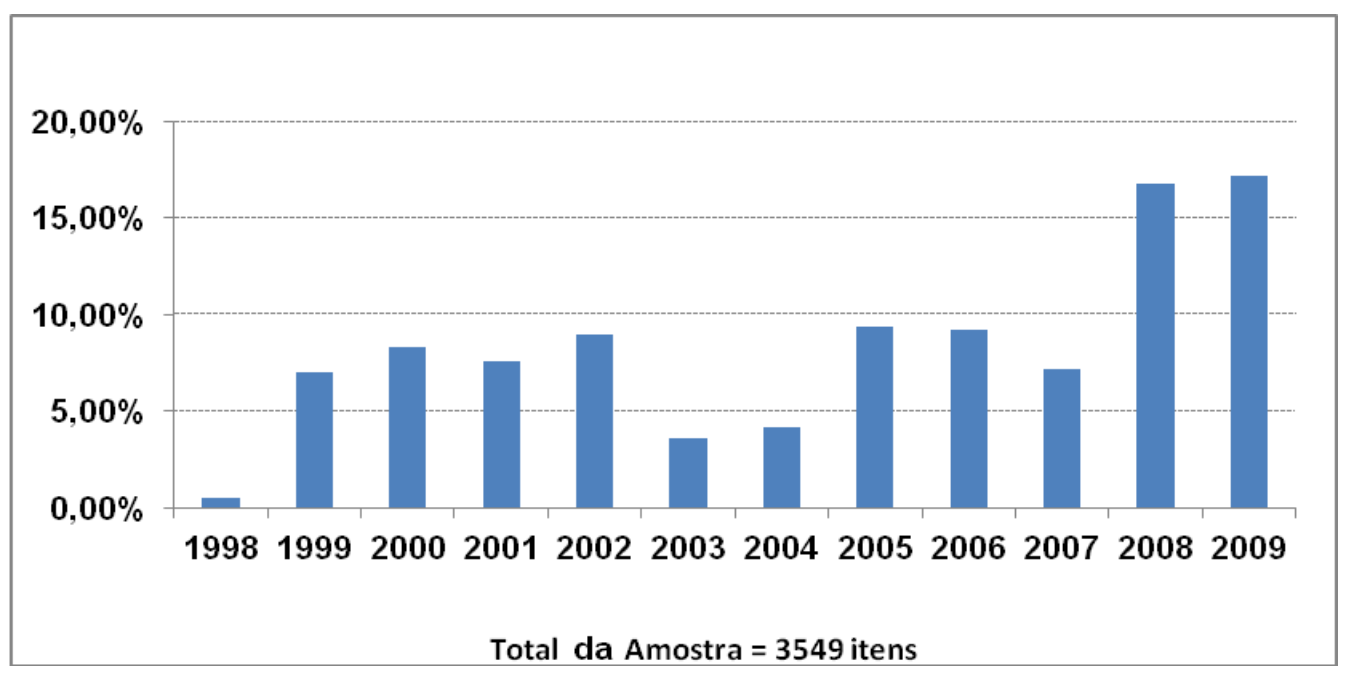

Diversos motivos podem explicar este resultado, além dos critérios utilizados para decidir sobre necessidade de registro do bem no sistema. Entre outros fatores, a 
geração de REEE pode depender de verbas destinadas à aquisição/renovação de equipamentos de novas tecnologias, projetos e reformas, expansão das atividades, etc.

\subsubsection{Distribuição da geração de REEE do Campus QS/D, por tipo de material}

O processo de classificação dos bens baixados no SIAP - MERCURIO por tipo de material apresentou um considerável grau de dificuldade, em função da falta de critério na alimentação do sistema, que é operado por muitas pessoas, com diferentes tipos de formação profissional e níveis de escolaridade. Há várias descrições para um mesmo produto e distintas grafias para uma mesma palavra. Em alguns casos a informação é tão vaga que torna impossível identificar o material. Alguns itens foram desconsiderados, por falta de dados suficientes para sua classificação. Inicialmente os EEE foram classificados por grupos, de acordo com a descrição registrada no sistema. Os resultados, resumidos na Tabela 3, indicam que a maioria dos REEE baixados corresponde ao grupo de equipamentos de informática, como CPUs, monitores, impressoras, scanners, fotocopiadoras e telecomunicações (TIC).

Tabela 3 - Distribuição de REEE baixados do Campus QS/D da USP, por grupos de material (1999-2009)

\begin{tabular}{l|r}
\hline \multicolumn{1}{c|}{ GRUPO DE MATERIAL } & \multicolumn{2}{c}{$\begin{array}{c}\text { FREQUENCIA } \\
\text { (unidades) }\end{array}$} \\
\hline Baterias & 49 \\
\hline Equipamentos de Consumo & 182 \\
\hline CPUs & 1013 \\
\hline Eletrodomésticos & 224 \\
\hline Equipamentos de Refrigeração & 121 \\
\hline Equipamentos de lluminação & 9 \\
\hline Impressoras \& scanners & 453 \\
\hline Equipamentos de Informática & 43 \\
\hline Equipamentos de Laboratório & 145 \\
\hline Máquinas \&ferramentas & 23 \\
\hline Medição \& controle & 71 \\
\hline Equipamentos Médicos & 41 \\
\hline Monitores & 1000 \\
\hline Não considerados & 2 \\
\hline Processadores de texto & 93 \\
\hline Equipamentos de telecomunicações & 65 \\
\hline Veículos & 15 \\
\hline TOTAL & 3.549 \\
\hline
\end{tabular}

Observou-se que acessórios e componentes de informática, assim como equipamentos de iluminação, baterias, máquina e ferramentas, aparecem com uma participação pequena em relação aos equipamentos de informática, em função da não 
obrigatoriedade de incorporação desse material ao patrimônio. Essa classificação pode não refletir fielmente a realidade, em função da arbitrariedade permitida pelo SIAP, na alimentação dos dados. O Gráfico 4 representa a participação percentual por grupos de tipos de material, conforme o registrado no sistema MERCURIO.

Gráfico 4 - Participação percentual de REEE baixados do Campus QS/D da USP, por tipo de material (1999 - 2009).

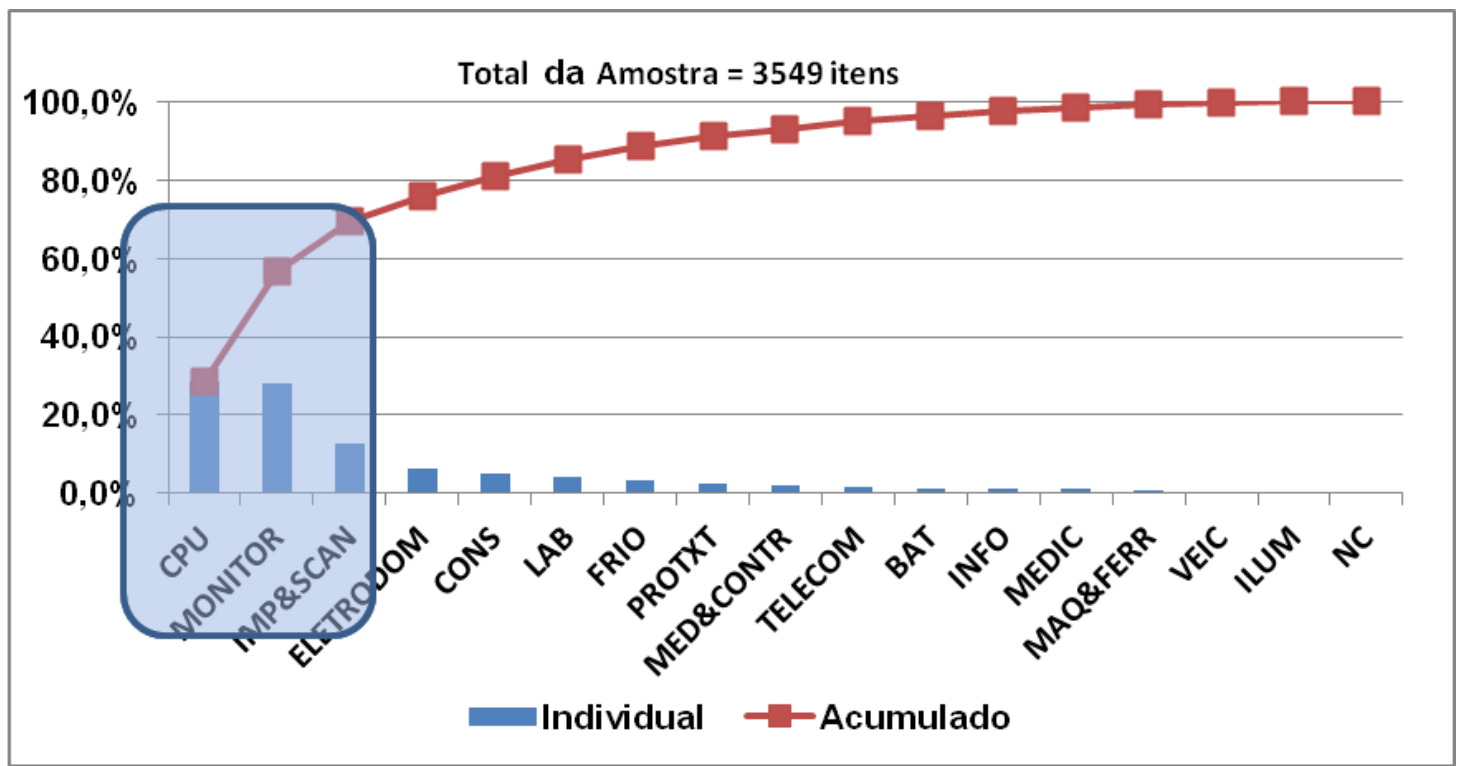

1) O grupo IMP\&SCAN (Impressoras \& Scanners) inclui as fotocopiadoras.

2) CONS. = EEE de consumo.

3) $L A B=$ Equipamentos de Laboratório.

4) $P R O T E X T=$ Processadores de texto, máquinas de escrever.

5) $M E D \& C O N T R=$ Equipamentos de Medição e Controle.

6) $B A T=$ Baterias.

7) INFO=Acessórios de Informática.

8) $M E D I C=$ Equipamentos Médicos.

9) $M A Q \& F E R R=$ Máquinas e Ferramentas.

10) $V E I C=$ Veículos. 11) ILUM = Equipam. de iluminação. 12) $N C=$ Não considerados

\subsubsection{Classificação dos REEE baixados do QS/D da USP, segundo a periculosidade}

Observou-se falta de conhecimento e de clareza, sobre quais REEE são considerados perigosos, entre os setores envolvidos em sua gestão. Pode-se dizer, no entanto, que grande parte desses resíduos, quando gerenciados corretamente, poderia ser classificada como REEE não perigosos. Procedimentos simples como, por exemplo, retirada dos cartuchos das impressoras antes do descarte, poderiam contribuir para que o volume de resíduos perigosos gerado na instituição diminuísse consideravelmente. A 
maioria dos REEE possui valor econômico agregado e há uma grande demanda por esse material no mercado secundário (comércio de reciclados), especialmente por metais. Aqueles que não são interessantes, do ponto de vista econômico ou de reciclagem, devem ser descontaminados e tratados antes de sua disposição final.

Nesta pesquisa, foram considerados perigosos todos os REEE que possuíam componentes perigosos no momento da baixa, segundo os critérios da Lista Europeia de Resíduos (LER), devido à constatação da inexistência de procedimentos para retirada desse material, antes de seu descarte. Esses incluem, entre outros, impressoras, fotocopiadoras e equipamentos que funcionam com baterias, como os pequenos EEE portáteis e impressoras, por incluir cartuchos de tinta e toners no momento de seu descarte. Dos 7781 itens analisados, 54,3\% dos itens baixados do SIAP entre 1999 e 2009 não foram considerados na análise, por não pertencer à categoria de REEE. Em geral, fazem parte do grupo de mobiliário e, alguns foram classificados como "outros", por insuficiência de dados.

O Gráfico 5 mostra a participação percentual por periculosidade, dos 3549 itens REEE considerados, classificados em perigosos (P) e não perigosos (NP), e não considerados (NC) Esses últimos foram assim classificados por não se enquadrar nas categorias consideradas. Entre os NC estão grandes instalações industriais fixas, veículos motorizados de uso externo, resíduos de equipamentos com radioatividade, entre outros.

Gráfico 5 - Participação percentual de REEE por periculosidade, baixados do Campus QS/D da USP (1999 - 2009)

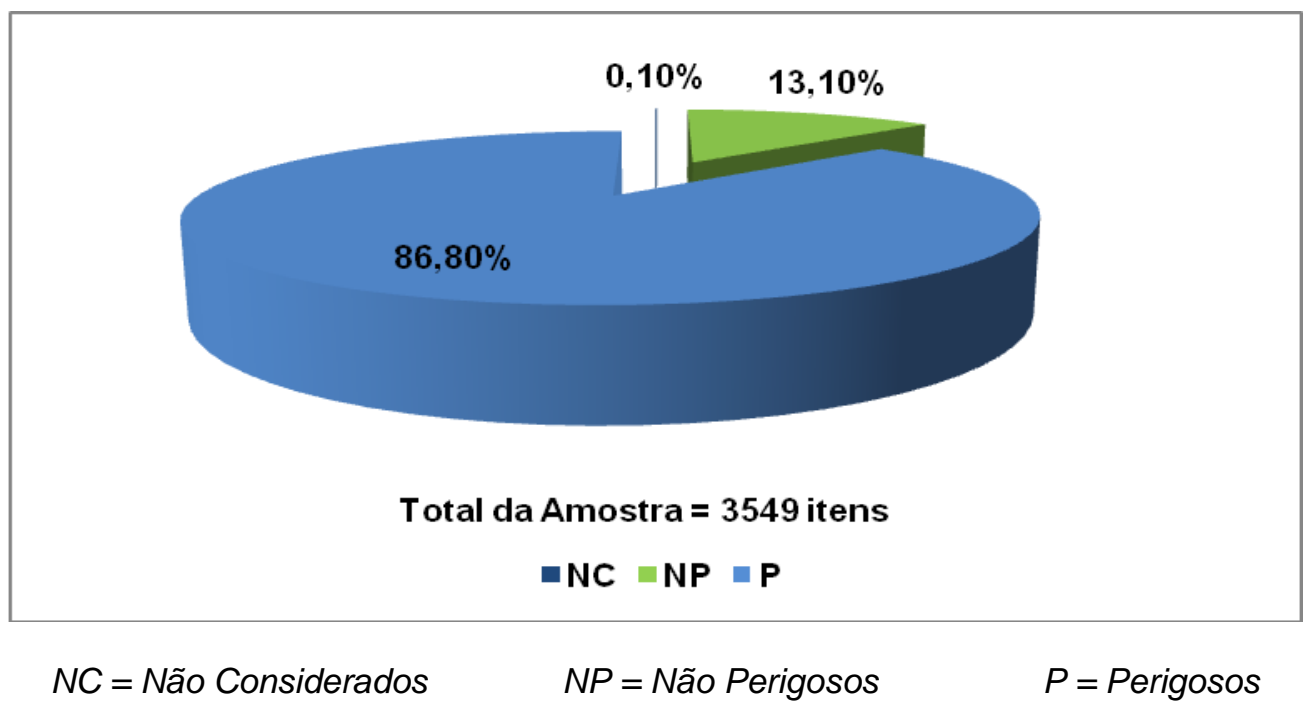




\subsubsection{Classificação dos REEE baixados do QS/D da USP, por categorias WEEE}

A classificação dos REEE em diferentes categorias não é definida a nível internacional. Portanto, existem várias classificações, de acordo com diferentes perspectivas. A classificação por categorias WEEE da UE contempla os REEE do ponto de vista dos produtores. A distribuição de cada categoria dos REEE baixados no Campus QS/D da USP, segundo essa classificação está detalhada na Tabela 4.

Tabela 4 - Distribuição de REEE baixados do Campus QS/D da USP, por categoria WEEE (UE) (1999 - 2009)

\begin{tabular}{|c|c|c|}
\hline CATEGORIA WEEE & FREQUÊNCIA (unidades) & PARTICIPACAO $\%$ \\
\hline 1 & 357 & $10.1 \%$ \\
\hline 2 & 26 & $0.7 \%$ \\
\hline 3 & 2742 & $77.8 \%$ \\
\hline 4 & 110 & $3.1 \%$ \\
\hline 5 & 9 & $0.3 \%$ \\
\hline 6 & 15 & $0.4 \%$ \\
\hline 8 & 42 & $1.2 \%$ \\
\hline 9 & 224 & $6.4 \%$ \\
\hline Total & 3525 & $100.0 \%$ \\
\hline $\begin{array}{l}\text { 1: Grandes eletrodomésti } \\
\text { 2: Pequenos eletrodomést } \\
\text { 3: Equipamentos de infor } \\
\text { 4: Equipamentos eletrôni }\end{array}$ & $\begin{array}{cc} & \text { 5: Equipamen } \\
& \text { 6: Ferramento } \\
& \text { 8: Equipame } \\
\text { onsumo Categoria } & \text { 9: Instrumer }\end{array}$ & $\begin{array}{l}\text { iluminação } \\
\text { ricas e eletrônicas } \\
\text { nédicos } \\
\text { e medição e controle }\end{array}$ \\
\hline
\end{tabular}

A análise dos dados indica que, a grande maioria dos REEE baixados do Campus QS/D da USP, entre 1999 e 2009, pertence à categoria 3 (WEEE), correspondente aos equipamentos de informática e de telecomunicações, conhecidos por equipamentos de tecnologia da informação (TI). A categoria 1, com uma participação superior a 10\% dos REEE baixados do Campus QS/D da USP no período investigado, representa parte importante desse material, tanto por suas características de periculosidade (equipamentos de refrigeração, lavadoras, etc.), como por seu volume. De um modo geral, esses EEE são patrimoniados, embora muitas vezes isso não ocorra com grande parte de equipamentos de ar condicionado. Quando gerenciados corretamente, com a retirada de componentes perigosos - espumas de poliuretano impregnadas com CFC, gases de refrigeração, óleo mineral contendo PCB - esses REEE consistem, na maioria dos casos, em material reciclável e valorizável, principalmente por seu conteúdo de metais. 
Observa-se uma pequena participação da categoria 2 (WEEE) que corresponde resíduos de pequenos eletrodomésticos, baixados do Campus QS/D da USP, no mesmo período. Nessa categoria incluem-se, entre outros, cafeteiras, liquidificadores e portáteis em geral, destinados ao consumo. Esse resultado pode ser consequência dos diferentes critérios utilizados para a incorporação, ou não, desse material ao patrimônio de cada unidade, conforme os conceitos de Administração Patrimonial, (ANEXO I). O mesmo motivo pode explicar a pequena participação percentual dos REEE correspondentes às categorias 5 (equipamentos de iluminação) e 6 (ferramentas elétricas), apesar de sua onipresença e larga utilização na prática. As categorias 7 (brinquedos e equipamentos de esporte e lazer) e 10 (máquinas de venda automática), não aparecem entre os REEE analisados, embora se tenha verificado sua presença nas instituições, o que pode indicar que esses equipamentos não estejam sendo patrimoniados. Na categoria 4, incluem-se equipamentos eletrônicos de consumo, tais como, televisores, equipamentos de áudio e vídeo, equipamentos de fotográficos, etc., cuja participação pode estar também subestimada, em função dos critérios adotados para a incorporação dos bens. Conforme os conceitos de administração patrimonial (ANEXO I), não há necessidade de se incorporar os bens de consumo ao patrimônio. Porém, na maioria das vezes, esses REEE possuem componentes perigosos, como baterias, lâmpadas e mesmo monitores de vídeo. A categoria 8 corresponde a equipamentos médicos e, a categoria 9, a instrumentos de medição e controle, nas quais estão incluídos os equipamentos de laboratório, entre outros. Geralmente são considerados REEE perigosos e devem passar por processo de descontaminação antes de serem encaminhados à disposição final.

\subsubsection{Classificação dos REEE baixados do QS/D da USP, por categoria de cor}

Segundo essa classificação, observa-se que, no período de 1999 a 2009, novamente a grande maioria dos REEE baixados no Campus QS/D da USP corresponde aos resíduos de TIC, da linha cinza, confirmando a predominância desses EEE nas IES, conforme o indicado na Tabela 5 e no Gráfico 6. 
Tabela 5 - Distribuição dos REEE baixados do Campus QS/D da USP, por categoria de cor $(1999-2009$

\begin{tabular}{lc}
\hline COR & FREQUENCIA (unidades) \\
\hline BRANCA & 374 \\
\hline CINZA & 2802 \\
\hline MARROM & 86 \\
\hline NC & 24 \\
\hline OUTROS & 263 \\
\hline Total & $\mathbf{3 5 4 9}$ \\
\hline \multicolumn{2}{c}{$N C=$ Não Considerados }
\end{tabular}

Gráfico 6 - Participação percentual de REEE baixados por categoria de cor $(1999-2009)$

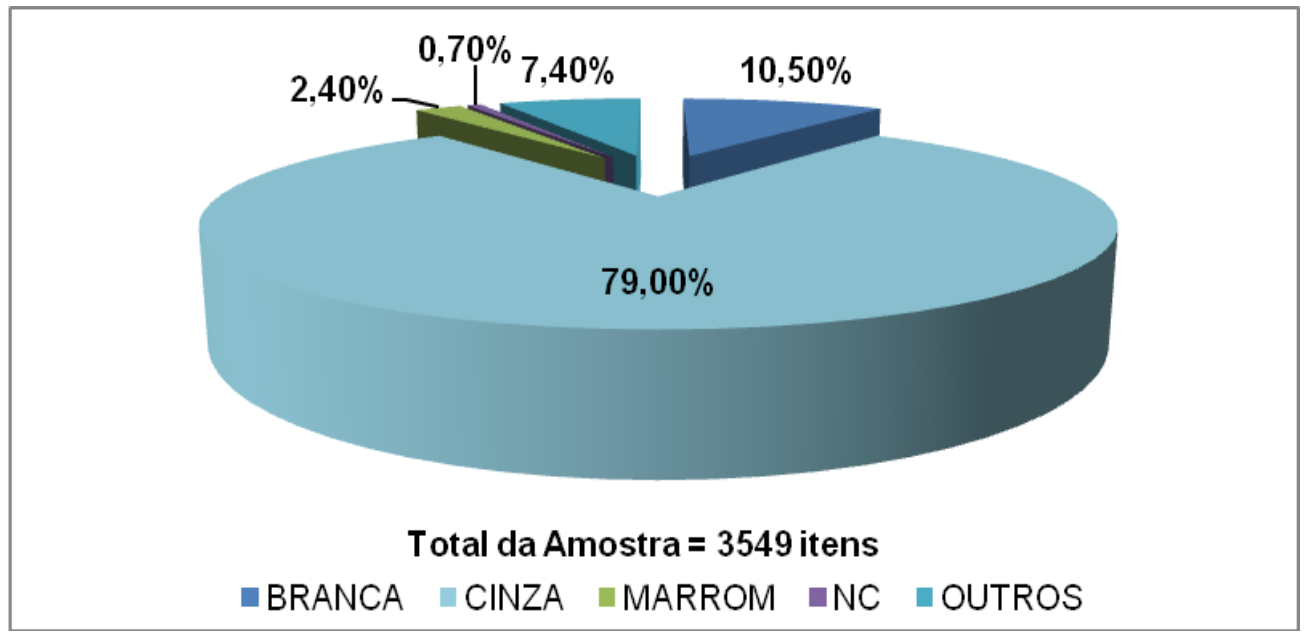

\subsubsection{Classificação dos REEE baixados do QS/D da USP por categoria de reciclagem}

Segundo as empresas recicladoras de REEE, após a desmontagem para a retirada dos componentes perigosos, os processos de reciclagem para a maioria desses equipamentos são praticamente os mesmos. Deste ponto de vista, a classificação orienta-se por aspectos operacionais, como composição, tipo de tratamento e transporte dos REEE e dividem-se em cinco categorias operacionais, conforme o detalhado e justificado e no Quadro 5. 
Quadro 5 - Classificação dos REEE segundo a categoria de reciclagem

\begin{tabular}{|l|lll|}
\hline No. & CATEGORIA & EXEMPLOS & JUSTIFICATIVA \\
\hline $\mathbf{1}$ & $\begin{array}{l}\text { Equipamentos } \\
\text { que contêm gases } \\
\text { de refrigeração }\end{array}$ & $\begin{array}{l}\text { Geladeiras, } \\
\text { congeladores, } \\
\text { bebedouros... }\end{array}$ & $\begin{array}{l}\text { Requerem transporte seguro (sem } \\
\text { rupturas) e tratamento especial }\end{array}$ \\
\hline $\mathbf{2}$ & $\begin{array}{l}\text { Eletrodomésticos } \\
\text { grandes e médios } \\
\text { (exceto os da } \\
\text { categ.1) }\end{array}$ & $\begin{array}{l}\text { Lavadoras, secadoras, } \\
\text { fornos de microondas, } \\
\text { processadores de } \\
\text { alimentos... }\end{array}$ & $\begin{array}{l}\text { Contêm diferentes metais e plásticos que } \\
\text { podem ser tratados segundo os padrões } \\
\text { atuais. Requerem transporte seguro (sem } \\
\text { rupturas) e tratamento especial }\end{array}$ \\
\hline $\mathbf{3}$ & $\begin{array}{l}\text { Equipamentos de } \\
\text { iluminação }\end{array}$ & $\begin{array}{l}\text { Tubos fluorescentes, } \\
\text { lâmpadas, luminárias }\end{array}$ & $\begin{array}{l}\text { Requerem processos especiais de } \\
\text { reciclagem ou de valorização. }\end{array}$ \\
\hline $\mathbf{4}$ & $\begin{array}{l}\text { Equipamentos com } \\
\text { monitores e telas de } \\
\text { vídeo }\end{array}$ & $\begin{array}{l}\text { Televisores, monitores } \\
\text { TRC, Monitores LCD }\end{array}$ & $\begin{array}{l}\text { Requerem transporte seguro (sem } \\
\text { rupturas) e tratamento individual. }\end{array}$ \\
\hline $\mathbf{5}$ & $\begin{array}{l}\text { Outros } \\
\text { equipamentos } \\
\text { elétricos e } \\
\text { eletrônicos }\end{array}$ & $\begin{array}{l}\text { Equipamentos de } \\
\text { informática, escritório, } \\
\text { eletrônicos de } \\
\text { consumo, linha } \\
\text { marrom. }\end{array}$ & $\begin{array}{l}\text { São compostos, em princípio, dos } \\
\text { mesmos materiais e componentes e, } \\
\text { portanto, requerem tratamentos de } \\
\text { reciclagem ou de valorização muito } \\
\text { semelhantes. }\end{array}$ \\
\hline
\end{tabular}

REIDLER, 2011 - Adaptado de RELEC, 2006

A Tabela 6 mostra a frequência em unidades de cada categoria de reciclagem, dos REEE baixados no da USP, no período investigado.

Tabela 6 - Distribuição dos REEE baixados do QS/D por categoria operacional $(1999-2009)$

\begin{tabular}{lr}
\hline \multicolumn{1}{c}{ CATEGORIA DE RECICLAGEM } & FREQUÊNCIA (unidades) \\
\hline 1. Eletrodomésticos que contêm refrigeração & 129 \\
\hline 2. Outros eletrodomésticos grandes e médios & 248 \\
\hline 3. Equipamentos de iluminação & 13 \\
\hline 4. EEE com monitores TRC e LCD & 1108 \\
\hline 5. Outros EEE & 2029 \\
\hline Total* & $\mathbf{3 5 2 7}$ \\
\hline
\end{tabular}

Os resultados sugerem que os equipamentos de iluminação, apesar de provavelmente constituir o material mais utilizado e o mais substituído em todas as unidades da instituição, apresentam uma frequência mínima de registro de REEE baixados no SIAP do QS/D da USP. Este fato se deve a que esse tipo de equipamento seja quase sempre considerado como material de consumo que, não sendo incorporados 
ao patrimônio, não é baixado do SIAP. Este resultado não corresponde à realidade, em termos de REEE descartados. Pode-se deduzir que, apesar de constituir resíduos perigosos, esses são descartados, na maioria das vezes, sem nenhum tipo de controle. A participação percentual dos REEE baixados do Campus QS/D da USP, de cada categoria operacional, do ponto de vista de reciclagem, está representada no Gráfico7.

Gráfico 7 - Participação de REEE baixados do Campus QS/D da USP, por categoria de reciclagem (1999 - 2009)

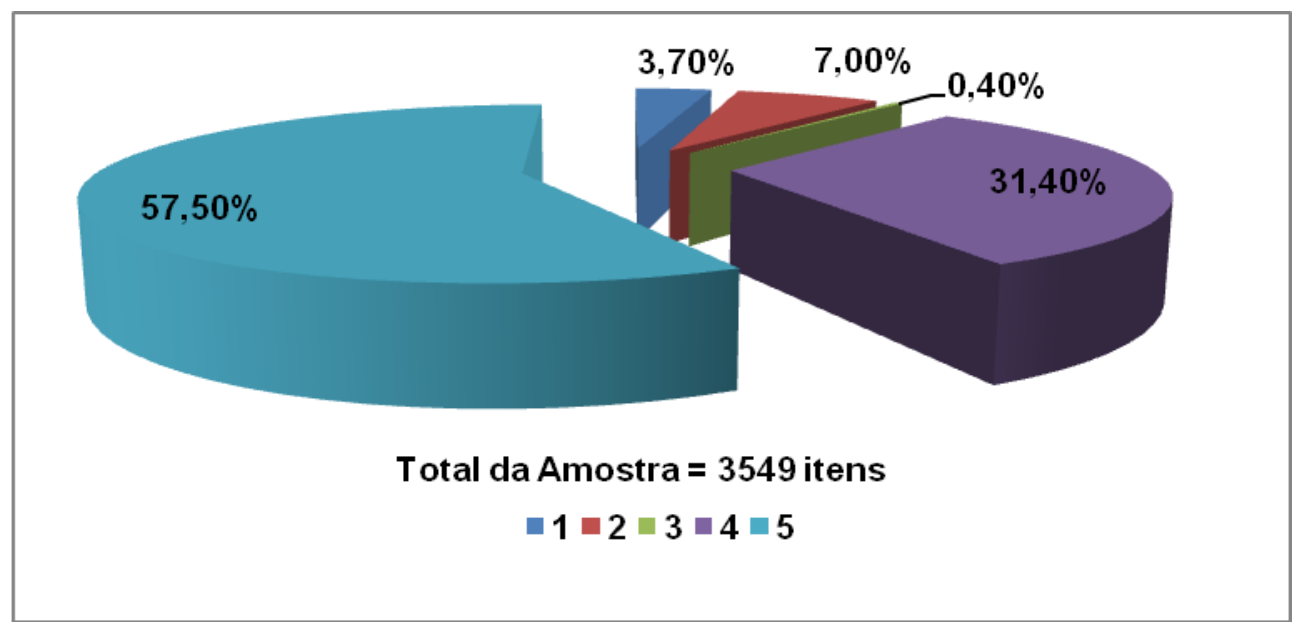

1. Eletrodomésticos que contêm gases de refrigeração

2. Outros eletrodomésticos grandes e médios

3. Equipamentos de iluminação

4. EEE com monitores TRC e LCD

5. Outros REEE

As maiores participações percentuais das categorias 4 e 5 , do ponto de vista operacional de reciclagem, confirmam uma vez mais que a grande maioria de EEE baixados do QS/D da USP é de resíduos TIC. Os classificados na categoria 5 correspondem aos REEE em geral e, além de equipamentos de informática, incluem pequenos eletroeletrônicos e equipamentos da linha marrom, entre outros. Entre os classificados na categoria 4 estão os equipamentos com monitor (LCD, TRC, microcomputadores portáteis, televisores, instrumentos de medição e controle, etc.).

Os eletrodomésticos grandes e médios classificados na categoria 2, que não possuem refrigeração, têm uma participação importante sob o ponto de vista de reciclagem, pois possuem valor econômico agregado e em geral não são resíduos perigosos, após a retirada de alguns componentes, como óleo mineral de compressores, lâmpadas e baterias. Esta categoria inclui lavadoras, secadoras, equipamentos de áudio, fornos, centrífugas, exaustores de gases, enceradeiras, entre outros, que geralmente são 
patrimoniados. Os eletrodomésticos que contêm elementos de refrigeração pertencem à categoria $1 \mathrm{e}$, sua relativamente pequena participação pode ser justificada por sua maior durabilidade e menor frequência de substituição. Após a retirada dos componentes perigosos, são também interessantes do ponto de vista de reciclagem.

\subsubsection{Estimativa do volume em peso dos REEE baixados no QS/D - USP por ano}

Estimar a geração dos REEE baixados do Campus QS/D da USP por volume em peso foi a etapa que apresentou a maior dificuldade de aproximação, em função da falta de informação sobre essa variável. Para resolver essa questão, recorreu-se aos pesos médios $(\mathrm{kg})$ dos equipamentos, na maioria dos casos (87\%), disponíveis na página web da Furniture Reuse Network (FRN, 2009), que fornece esses valores para uma grande variedade de produtos. Quando o item não constava dos registros do FRN, obteve-se a informação mediante contato direto com o fabricante ou por consulta à sua página web. $\mathrm{Na}$ falta de dados suficientes para identificar o material, calculou-se o peso médio $(\mathrm{kg})$ de produtos similares, considerando-se os dados de no mínimo cinco equipamentos do mesmo tipo. Dos 3549 itens analisados, 24 não foram considerados, por falta de dados suficientes para sua caracterização. A Tabela 7 representa a distribuição por peso médio (kg) estimado dos REEE do QS/D baixados por unidade e ano, no período investigado.

Tabela 7 - Estimativa do peso total (kg) de REEE baixados do QS/D por unidade/ano (1999 - 2009.

\begin{tabular}{lrrrrrr}
\hline \multicolumn{7}{c}{ PESO $(\mathbf{k g})$ de REEE BAIXADO / UNIDADE DO QS/D } \\
\hline ANO & EE & FD & FM & FSP & IMT & QS/D \\
\hline $\mathbf{1 9 9 9 *}$ & 572,0 & 379,0 & 600,0 & 1791,0 & - & $\mathbf{3 3 4 2 , 0}$ \\
\hline $\mathbf{2 0 0 0}$ & 336,5 & 1651,0 & 480,5 & 732,5 & - & $\mathbf{3 2 0 0 , 5}$ \\
\hline $\mathbf{2 0 0 1}$ & 32,0 & 583,0 & 310,0 & 2217,5 & - & $\mathbf{3 1 4 2 , 5}$ \\
\hline $\mathbf{2 0 0 2}$ & 1182,0 & 231,0 & 360,5 & 1737,5 & - & $\mathbf{3 5 2 5 , 0}$ \\
\hline $\mathbf{2 0 0 3}$ & 74,0 & 407,5 & 450,5 & 490,0 & - & $\mathbf{1 4 2 2 , 0}$ \\
\hline $\mathbf{2 0 0 4}$ & 898,0 & 240,5 & 123,5 & 648,5 & - & $\mathbf{1 9 1 0 . 5}$ \\
\hline $\mathbf{2 0 0 5}$ & 1687,1 & 152,0 & 1292,0 & 1278,5 & - & $\mathbf{4 4 0 9 . 6}$ \\
\hline $\mathbf{2 0 0 6}$ & 25,0 & 1699,0 & 404,5 & 1765,5 & - & $\mathbf{3 8 9 4 , 0}$ \\
\hline $\mathbf{2 0 0 7}$ & 1051,0 & 1336,0 & 239,5 & 117,0 & - & $\mathbf{2 7 4 3 . 5}$ \\
\hline $\mathbf{2 0 0 8}$ & 35,0 & 3120,0 & 389,0 & 3839,0 & 159,0 & $\mathbf{7 5 4 2 , 0}$ \\
\hline $\mathbf{2 0 0 9}$ & 3923,5 & 102,0 & 501,0 & 2357,5 & 503,5 & $\mathbf{7 3 8 7 . 5}$ \\
\hline TOTAL & $\mathbf{9 8 1 6 , 1}$ & $\mathbf{9 9 0 1 , 0}$ & $\mathbf{5 1 5 1 , 0}$ & $\mathbf{1 6 9 7 4 , 5}$ & $\mathbf{6 6 2 , 5}$ & $\mathbf{4 2 . 5 1 9 , 1}$ \\
\hline
\end{tabular}

*Os REEE baixados em 1998 foram doados em 1999 e, portanto, foram considerados juntos. 
A análise desta variável indica uma disparidade de valores entre a quantidade estimada em peso de REEE gerada em cada unidade e seus indicadores numéricos. A FSP, para citar o exemplo mais marcante, com praticamente a metade do orçamento da FM e uma população cerca de quatro vezes menor, teve o triplo (em peso estimado) de REEE baixados no mesmo período. Considera-se que, neste caso, os dados levantados no SIAP não são suficientes para esclarecer essa questão.

\subsubsection{Motivo da baixa dos bens}

Apesar de existir um campo no SIAP para que se registre o motivo da baixa, esse dado nem sempre é informado, conforme se pode verificar na Tabela 8.

Tabela 8 - Distribuição dos motivos de baixa dos REEE dos QS/D USP (1999 - 2009)

\begin{tabular}{lcl}
\hline MOTIVO BAIXA & FREQUÊNCIA & PORCENTAGEM \\
\hline N/C (não consta) & 1347 & $38.0 \%$ \\
\hline Por inservível & 1733 & $48.8 \%$ \\
\hline Por quebra, desgaste ou avaria & 313 & $8.8 \%$ \\
\hline Outros & 156 & $4.4 \%$ \\
\hline Total & $\mathbf{3 5 4 9}$ & $\mathbf{1 0 0 . 0 \%}$ \\
\hline
\end{tabular}

Existem muitos fatores que podem dar margem a explicações sobre o motivo da baixa de REEE. Entre esses estão obsolescência, má manutenção, mau uso, substituição por versões mais novas, falta de peças, roubo, consumo irresponsável, interesses comerciais e muitos outros. Alguns podem se encontrados nos processos de baixa, outros foram sugeridos por pessoal que trabalha no Setor de Patrimônio. Esses dados nem sempre são informados, o que indica o SIAP não exige que todos os campos sejam preenchidos para efetivar o registro de baixa.

Os resultados obtidos no levantamento no Sistema MERCURIO mostraram que um sistema de informação para a administração patrimonial bem estruturado poderia constituir excelente ferramenta de gestão integrada de REEE. As dificuldades enfrentadas no levantamento poderiam ser minimizadas por uma reformulação do SIAP, eliminando dados supérfluos, que acabam por gerar informações confusas e conflitantes, como por exemplo, quatro colunas para descrever o mesmo material. Por outro lado, a padronização de dados para alimentação do sistema, a impossibilidade de concluir o processo de baixa sem o fornecimento de todos os dados solicitados e a inclusão de 
informações importantes, como data de entrada, peso do material e destinação após a baixa, possibilitariam o conhecimento de dados fundamentais para a gestão integrada desses resíduos, como vida útil dos EEE, volume em peso e fluxo de REEE gerados. A capacitação das pessoas que operam o sistema para alimentação de dados seria obrigatória. Observou-se uma total falta de preparo para a função e muita dificuldade na descrição do bem, realizada com a boa vontade e a criatividade do operador, que não tem a obrigação de conhecer todos os tipos de material adquiridos por outros departamentos. Esta constatação leva a outras. O setor de compras deveria estar integrado com o setor de patrimônio e o responsável pelo equipamento deveria fornecer as informações necessárias para sua baixa.

A análise quantitativa dos dados levantados no sistema de informação da administração patrimonial da USP, com o objetivo de estimar o volume, caracterizar os tipos de REEE gerados e conhecer seus fluxos, apontou para a necessidade de informações complementares, para a obtenção do diagnóstico da situação desses resíduos nas unidades do Campus QS/D da USP.

\subsection{USP - ANÁLISE QUALITATIVA E INTERPRETAÇÃO DOS RESULTADOS}

Verificou-se que os dados de destino dos bens considerados inservíveis não são registrados no Sistema de Informação da Administração Patrimonial da USP, mas essa informação geralmente consta dos processos referentes à baixa do material patrimoniado, arquivados em papel pelo Setor de Patrimônio de cada unidade. Esses processos são abertos e encerrados anualmente, mas podem ocorrer com maior frequência, dependendo do volume de bens baixados e da falta de espaço para abrigar o material a ser descartado. Cada unidade realiza os procedimentos de baixa de maneira individual, mas o sistema de informação da Administração Patrimonial é comum a todas as unidades e recebe os dados de cada uma delas, que alimentam um sistema de informação central (neste caso o Sistema MERCURIO). As pastas contendo a documentação relativa aos processos encerrados são encaminhadas para o "arquivo morto" e lá permanecem por tempo indeterminado, sendo possível solicitar uma consulta, quando necessário. Em vista disso, solicitou-se autorização para realizar uma 
pesquisa documental nos processos de baixa, nos respectivos setores de patrimônio, com a finalidade de investigar o fluxo e o destino dos REEE gerados em cada unidade, como ponto de partida para a análise qualitativa.

\subsubsection{Investigação do destino dos REEE baixados do Campus QS/D da USP}

Dos processos de baixa constam, entre outros documentos, ofícios solicitando autorização de baixa dos bens inservíveis e irrecuperáveis, incluindo uma relação dos mesmos com a justificativa da solicitação, de acordo com o Manual de Administração Patrimonial (GEFIM, 2004, COMPATRIM, 2010). Além da documentação de praxe, geralmente estão incluídas no processo as correspondências referentes a informações sobre casos especiais, transferências, doações e locais de destino. Dos processos não constam, por exemplo, registro sobre a aquisição ou sobre o histórico de manutenção dos EEE que poderiam acrescentar informações importantes para se estimar o tempo de vida útil dos equipamentos e controlar procedimentos de gestão, tais como compras em excesso, desperdícios, mau uso, etc.

Segundo o Manual de Administração Patrimonial (GEFIM, 2004), antes da baixa, os bens deverão ser divulgados no Sistema de Informação PROTEUS da USP, onde ficarão disponíveis para outras unidades durante 15 dias, na intranet. Após esse período, se não houver interesse para reutilização interna, sua doação somente poderá ser feita para entidades declaradas de utilidade pública, órgãos ou entidades da Administração Pública, exclusivamente para fins e uso de interesse social, sem fins lucrativos, que apresentem a documentação exigida.

A partir de 2010, de acordo com a nova versão do Manual de Administração Patrimonial (COPATRIM, 2010), os bens considerados inservíveis, pertencentes ao grupo de informática e telecomunicações, de todas as unidades da instituição, em condições de uso ou não, deveriam ser encaminhados ao Centro de Descarte e Reuso de Resíduos de Informática (CEDIR), de acordo com as normas de entrega do referido centro. O CEDIR, inaugurado em 2009, foi um projeto desenvolvido pelo Centro de Computação Eletrônica (CCE), responsável pelo atendimento em informática às unidades da USP, na capital (CCE, 2009). 


\subsubsection{Visitas às unidades que compõem o Campus QS/D da USP}

Com o objetivo de estabelecer contato com os departamentos envolvidos com a questão dos REEE e identificar problemas, foram realizadas visitas às unidades que compõem o QS/D (EE, FD, FM, FSP e IMT) e a alguns setores agregados, localizados fora do Campus, cujo Setor de Patrimônio está subordinado a essas unidades. Entre esses estão o Serviço de Verificação de Óbitos da Capital (SVOC), ligado à FM, o Centro de Saúde Escola Geraldo de Paula Souza e o Serviço Especial de Saúde de Araraquara (SESA), ligados à FSP.

No caso dos bens patrimoniados, após o processo de baixa no SIAP, esses adquirem status de bens inservíveis e normalmente são doados. Observou-se que os procedimentos de descarte e destinação dos REEE são diferentes em cada unidade e, dependendo de seu tamanho e da complexidade administrativa, esses procedimentos podem variar de setor para setor, dentro da própria unidade, de maneira independente.

Durante as visitas, observou-se uma realidade paralela bastante distinta daquela registrada nos dados oficiais. Constatou-se, por exemplo, que diante da burocracia enfrentada para se conseguir comprar um equipamento, é procedimento comum se utilizar verbas destinadas a outras finalidades, para sua aquisição. Nesses casos, os produtos não são incorporados ao patrimônio da instituição e, portanto, não são baixados. Quando o material a ser descartado não está registrado no SIAP, é considerado como sucata e não necessita passar por processo de baixa. Nesse caso, não há procedimentos estabelecidos para sua destinação.

Os conceitos definidos no Manual de Administração Patrimonial são adotados em cada unidade de acordo com seus próprios critérios, para decidir se o bem deve ou não ser patrimoniado. Alteração de característica, avaliação, bens de consumo (incluindo equipamentos de iluminação, ferramentas, material de manutenção, componentes e peças), mudança de localização física do bem, mudança de responsabilidade, término de cessão e uso e upgrade de equipamentos são alguns dos motivos que causam dúvidas e geram confusão e descontrole no gerenciamento do material. Observou-se que existem muitos EEE, principalmente de TI, registrados de maneira inadequada no Sistema MERCURIO, ou mesmo não registrados, por desconhecimento das regras para o registro dos equipamentos. 
Outros fatores foram identificados também como motivos de não incorporação de material ao patrimônio. Entre as principais causas, está a falta de clareza na classificação do bem, como patrimoniável ou não. Geralmente, equipamentos como de iluminação, de telefonia, condicionadores de ar, baterias e EEE portáteis, de um modo geral, não são registrados no SIAP.

Por meio de reuniões com diretorias, aplicação de questionário semiestruturado, entrevistas informais com funcionários envolvidos com a questão dos REEE e de registros fotográficos, procurou-se identificar os principais problemas de gerenciamento desses resíduos em cada unidade e os critérios utilizados para a destinação de REEE após a baixa. A seguir, apresentam-se os resultados qualitativos obtidos nas visitas às unidades do Campus QS/D da USP, resumidos no Quadro 6 e em alguns registros fotográficos realizados na ocasião, quando permitidos. 
QUADRO 6 - Resumo dos resultados obtidos nas visitas às unidades do Campus QS/D

\begin{tabular}{|c|c|c|c|c|c|}
\hline & $\begin{array}{c}\text { Instrumentos de pesquisa } \\
\text { qualitativa }\end{array}$ & Gerenciamento de REEE & $\begin{array}{l}\text { Principais problemas } \\
\text { identificados }\end{array}$ & Principais destinos & Observações \\
\hline EE & $\begin{array}{l}\text { Pesquisa documental } \\
\text { Entrevistas individuais: com } \\
\text { vice-diretora e } \\
\text { encarregados dos Setores: } \\
\text { Administrativo, Financeiro, } \\
\text { Patrimônio, Informática, } \\
\text { Manutenção e Zeladoria. } \\
\text { Registro Fotográfico }\end{array}$ & $\begin{array}{l}\text { A área destinada ao } \\
\text { depósito de materiais } \\
\text { inservíveis é pequena e } \\
\text { insuficiente para cumprir } \\
\text { essa função (utilizada para } \\
\text { sucatas) } \\
\text { Os bens baixados aguardam } \\
\text { sua destinação nos próprios } \\
\text { departamentos de origem }\end{array}$ & $\begin{array}{l}\text { Falta de espaço para depósito } \\
\text { Falta integração entre os setores } \\
\text { Não há definição clara sobre } \\
\text { responsabilidades } \\
\text { Falta informação }\end{array}$ & $\begin{array}{l}\text { - Lar Escola São } \\
\text { Francisco }\left(^{*}\right) \\
\text { - Prefeituras } \\
\text { Municipais } \\
\text { - Exército } \\
\text { APAE }\left(^{*}\right) \\
\text { - Casas André Luiz }\end{array}$ & $\begin{array}{l}\text { Lâmpadas florescentes: } \\
\text { Recicladora NATURALIS } \\
\text { Pilhas e baterias: } \\
\text { descartadas junto com o } \\
\text { resíduo comum } \\
\frac{\text { Material não patrimoniado: }}{\text { doado ou junto com o lixo }} \text { comum }\end{array}$ \\
\hline FD & $\begin{array}{l}\text { Pesquisa documental. } \\
\text { Reunião: com } \\
\text { representante da diretoria e } \\
\text { encarregados dos Setores } \\
\text { de Patrimônio, Materiais, } \\
\text { Financeiro, Administrativo, } \\
\text { Informática, Manutenção, } \\
\text { Associação dos } \\
\text { funcionários, USP recicla. } \\
\text { Entrevistas individuais: com } \\
\text { Os participantes da reunião } \\
\text { Registro Fotográfico }\end{array}$ & $\begin{array}{l}\text { A área destinada ao } \\
\text { depósito de sucatas é um } \\
\text { galpão espaçoso, porem } \\
\text { insuficiente para abrigar } \\
\text { todos os bens baixados que } \\
\text { aguardam sua destinação } \\
\\
\text { A FD não possui um } \\
\text { depósito específico para } \\
\text { armazenar os bens } \\
\text { baixados. Após a baixa, } \\
\text { esses materiais aguardam a } \\
\text { destinação em seus } \\
\text { respectivos departamentos, } \\
\text { até o dia da coleta. } \\
\text { Excesso de burocracia }\end{array}$ & $\begin{array}{l}\text { Em função do tamanho da } \\
\text { unidade e da complexidade } \\
\text { administrativa, muitas pessoas } \\
\text { estão envolvidas com a questão } \\
\text { dos REEE, e não há integração } \\
\text { entre os setores } \\
\text { Falta uma área de depósito para } \\
\text { os bens baixados, que sirva a } \\
\text { todos os setores } \\
\text { Não há definição clara sobre } \\
\text { responsabilidades } \\
\text { Falta informação }\end{array}$ & $\begin{array}{l}\text { - Casas André Luiz }\left(^{*}\right) \\
\text { - ALIVI - Aliança para } \\
\text { a vida }\left(^{*}\right) \\
\text { - Órgãos da } \\
\text { Administração Pública } \\
\text { - Polícia Estadual }\end{array}$ & $\begin{array}{l}\frac{\text { Lâmpadas }}{\text { fluorescentes:armazenam em }} \\
\text { um deposito à espera de } \\
\text { solução } \\
\text { Pilhas e baterias: } \\
\text { descartadas junto com o } \\
\text { resíduo comum } \\
\frac{\text { Material não patrimoniado: }}{\text { doado ou junto com o lixo }} \text { comum }\end{array}$ \\
\hline FM & Pesquisa documental. & $\begin{array}{l}\text { O gerenciamento de REEE } \\
\text { é feito por } 5 \text { setores de }\end{array}$ & $\begin{array}{l}\text { Em função do tamanho da } \\
\text { unidade e da complexidade }\end{array}$ & $\begin{array}{l}\text { - FUSSESP }\left(^{* \star}\right) \\
\text { (doação) }\end{array}$ & $\begin{array}{l}\text { Grande parte dos } \\
\text { equipamentos pertence a }\end{array}$ \\
\hline
\end{tabular}




\begin{tabular}{|c|c|c|c|c|c|}
\hline & $\begin{array}{l}\text { Entrevistas individuais: com } \\
\text { o Diretor Administrativo e } \\
\text { os encarregados dos } \\
\text { Setores de: Gestão } \\
\text { Ambiental, Patrimônio, } \\
\text { Almoxarifado, Doação, } \\
\text { Manutenção, } \\
\text { Engenharia,Informática, } \\
\text { Comissão de benefícios } \\
\text { sociais, Zeladoria. } \\
\text { Análise dos registros de } \\
\text { sucata doada entre } 2008 \text { e } \\
2009 . \\
\text { Registro fotográfico. }\end{array}$ & $\begin{array}{l}\text { maneira individual, com } \\
\text { registros diferentes. } \\
\text { FMUSP - Sist. MERCURIO } \\
\text { SVOC - Sist. MERCURIO } \\
\text { FZ - INCOR outro sistema } \\
\text { FFM - outro sistema } \\
\text { LIMs - outro sistema } \\
\text { Departamento de Gestão } \\
\text { Ambiental registro de } \\
\text { sucatas doadas de REEE } \\
\text { (desde 2008) }\end{array}$ & $\begin{array}{l}\text { administrativa, muitas pessoas } \\
\text { estão envolvidas com a questão } \\
\text { dos REEE, e não há integração } \\
\text { entre os setores. } \\
\text { Falta uma área de depósito para } \\
\text { os bens baixados, que sirva a } \\
\text { todos os setores. } \\
\text { Não há definição clara sobre } \\
\text { responsabilidades. } \\
\text { Falta padronização de } \\
\text { procedimentos }\end{array}$ & $\begin{array}{l}\text { - Sucatas TALAMONI } \\
\text { (venda) } \\
\text { - Multilixo } \\
\text { (coleta paga) } \\
\text { - Reutilização em } \\
\text { creches } \\
\text { - Comercialização, } \\
\text { com renda destinada } \\
\text { à Comissão de } \\
\text { benefícios dos } \\
\text { funcionários da } \\
\text { FMUSP }\end{array}$ & $\begin{array}{l}\text { outras instituições, que } \\
\text { financiam ou participam de } \\
\text { projetos conjuntos. } \\
\text { Dificuldade de classificação } \\
\text { de bens patrimoniais, } \\
\text { equipamentos transferidos } \\
\text { sem registros } \\
\text { Lâmpadas fluorescentes: } \\
\text { TRAMPO } \\
\frac{\text { Pilhas e baterias: armazenam }}{\text { à espera de solução. }}\end{array}$ \\
\hline FS & $\begin{array}{l}\text { Pesquisa documental. } \\
\text { Entrevistas individuais: com } \\
\text { Coordenadoria de } \\
\text { Resíduos e encarregados } \\
\text { dos Setores de Patrimônio, } \\
\text { Compras, Almoxarifado, } \\
\text { Informática, Financeiro, } \\
\text { Administracao, Informática, } \\
\text { USP Recicla, Zeladoria. } \\
\text { Registro fotográfico }\end{array}$ & $\begin{array}{l}\text { Área insuficiente para } \\
\text { deposito de bens } \\
\text { inservíveis, que aguardam a } \\
\text { coleta em corredores e nos } \\
\text { departamentos de origem. } \\
\text { Não há controle nem } \\
\text { procedimentos para sucatas } \\
\text { e material não patrimoniado. }\end{array}$ & $\begin{array}{l}\text { Falta de informação e de } \\
\text { integração os setores, questões } \\
\text { políticas e administrativas } \\
\text { internas, falta de definição de } \\
\text { responsabilidades de aparecem } \\
\text { como sendo as principais } \\
\text { causas da dificuldade de gestão } \\
\text { dos REEE e são motivos de } \\
\text { conflitos. }\end{array}$ & $\begin{array}{l}\text { - Casas André Luiz } \\
\text { - Escolas Públicas } \\
\text { - Policia Militar do } \\
\text { Estado de SP } \\
\text { - USP Recicla } \\
\text { - LOGA (coleta paga) }\end{array}$ & $\begin{array}{l}\text { USP RECICLA destina os } \\
\text { REEE de componentes, } \\
\text { peças e periféricos (mouse, } \\
\text { teclado, etc.) e materiais não } \\
\text { patrimoniado, que quando } \\
\text { não é reutilizável, vai para o } \\
\text { lixo comum. } \\
\text { Lâmpadas: NATURALIS; } \\
\text { Pilhas e baterias: Papa-pilhas }\end{array}$ \\
\hline IMT & $\begin{array}{l}\text { Pesquisa documental. } \\
\text { Entrevistas individuais: com } \\
\text { encarregada do Setor de } \\
\text { Patrimônio, Assistente } \\
\text { Administrativo, } \\
\text { Manutenção, Informática. }\end{array}$ & $\begin{array}{l}\text { Parte registra no Sistema. } \\
\text { MERCURIO, parte } \\
\text { encaminha para a FMUSP, } \\
\text { da qual se desvinculou em } \\
2002 \text {, para gerenciamento } \\
\text { comum. Baixas somente a } \\
\text { partir de } 2008 \text {. }\end{array}$ & $\begin{array}{l}\text { Falta de informação, } \\
\text { Falta pessoal capacitado } \\
\text { gerenciar REEE. } \\
\text { Falta de estrutura. }\end{array}$ & $\begin{array}{l}\text { - FMUSP } \\
\text { - Coleta da Prefeitura }\end{array}$ & $\begin{array}{l}\text { REEE baixados e lâmpadas } \\
\text { são encaminhados para } \\
\text { descarte conjunto com a } \\
\text { FMUSP. } \\
\text { Material não patrimoniado. e } \\
\text { pilhas e baterias: lixo comum. }\end{array}$ \\
\hline
\end{tabular}

(*) Entidade filantrópica sem fins lucrativos.

(**) FUSSESP - Fundo de Solidariedade e Desenvolvimento Social e Cultural do Estado de SP 


\subsubsection{Armazenamento do material inservível}

De acordo com as informações obtidas nas visitas às unidades, a questão do depósito para o material inservível constitui um problema comum a todas as unidades do QS/D. Em alguns casos, os bens baixados permanecem nos departamentos de origem, em locais inadequados, ou mesmo em corredores, por absoluta falta de espaço. O material, que inclui REEE perigosos, fica exposto, a mercê de quem queira levá-lo, sem nenhum controle e sem que nenhuma medida de segurança seja tomada, conforme o registrado nas Figuras 2 e 3.

Figura 2 - Material baixado à espera de coleta, encontrado.

em baixo de uma pia, em unidade do QS/D

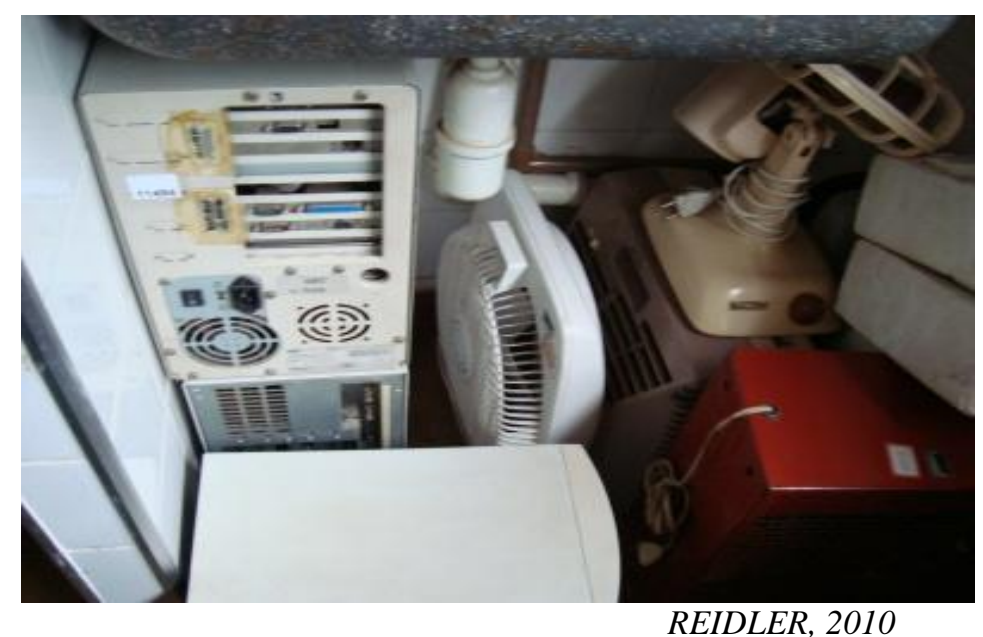

Figura 3 - Material baixado e sucata à espera de coleta, sem proteção, no corredor de uma unidade do QS/D

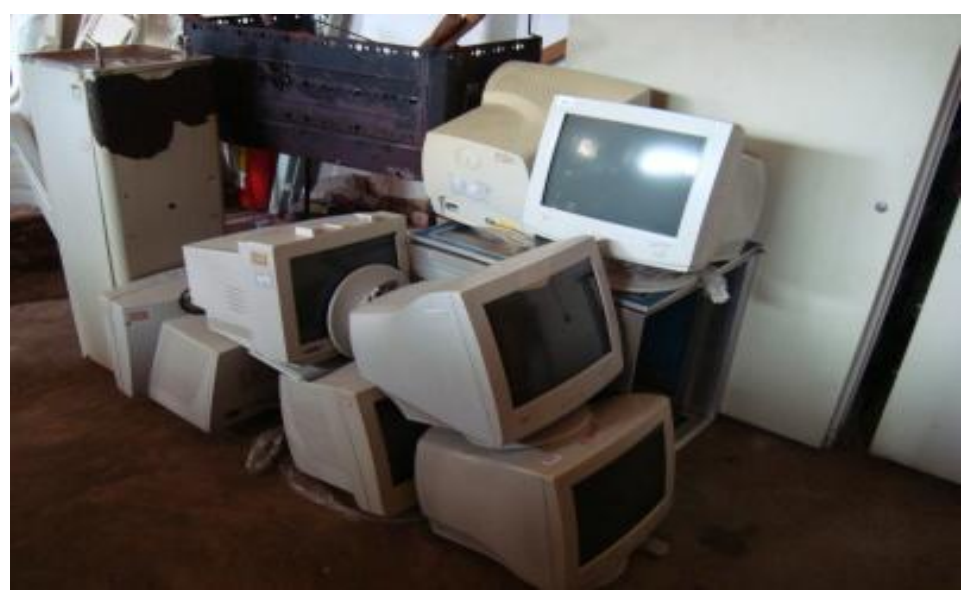

REIDLER, 2010

Observou-se que o armazenamento e o destino dos EEE inservíveis não patrimoniados do Campus QS/D da USP não obedecem a nenhum critério e variam de 
unidade para unidade e de setor para setor. Na maioria das vezes esses REEE podem ser perigosos quando não manejados corretamente. Pode-se citar como exemplo, os equipamentos de ar condicionado, de iluminação e baterias, entre outros. Os primeiros contêm gases de refrigeração, os quais requerem uma remoção especial. As baterias e equipamentos de iluminação contêm metais pesados e outras substâncias tóxicas e devem ser descontaminados antes de sua destinação final. Somente após a retirada dos componentes perigosos, esse material pode ser doado ou comercializado como sucata. Em alguns casos, mesmo quando os depósitos de bens baixados são bem organizados, o armazenamento da sucata é realizado de maneira diferente, na mesma unidade (Figuras 4 e 5). Mesmo quando o destino é registrado, o fluxo dos REEE doados não é verificado pela instituição.

Figura 4 - Depósito protegido de equipamentos de ar condicionado, baixados do patrimônio de unidade no Campus QS/D

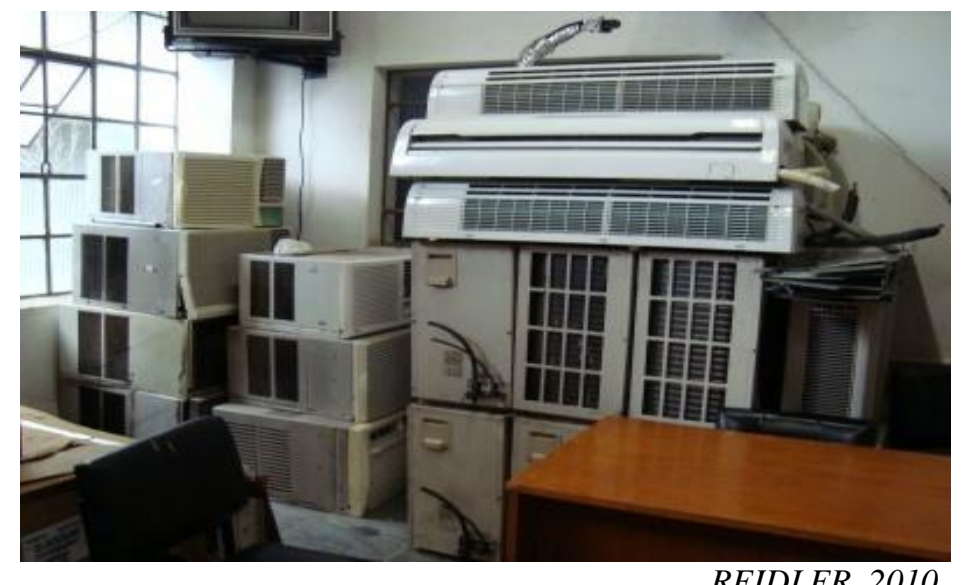

Verificou-se na FM, que por motivo de restauração do prédio principal, para manter o projeto original, foi decidido que não se utilizariam mais os equipamentos de ar condicionado que fossem visíveis na fachada externa. Os aparelhos em boas condições de uso foram retirados, registrados e armazenados corretamente, em espaços fechados e ventilados, dentro das normas de segurança estabelecidas, à espera de reutilização em outras unidades da USP. Entretanto, constatou-se que, na mesma unidade, os equipamentos não patrimoniados, incluindo máquinas, motores e luminárias externas, de responsabilidade de seu Setor de Engenharia, são armazenados de forma irregular, à espera de coleta para venda como sucata. Assim, pode-se facilmente identificar a existência de diferentes fluxos de REEE, gerados em uma mesma unidade. 
Figura 5 - Armazenamento temporário de REEE não patrimoniado em unidade do QS/D

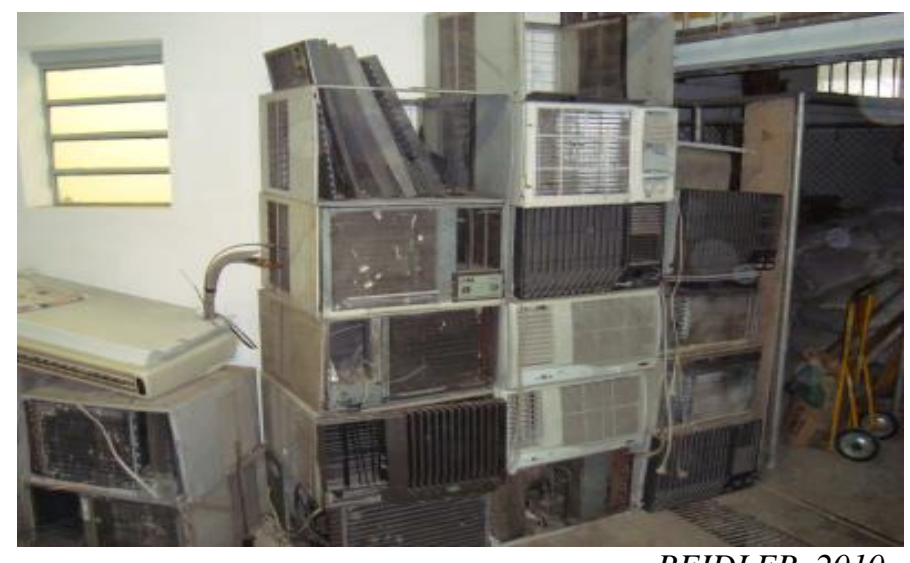

REIDLER, 2010

A estrutura da FM é complexa e compreende várias ramificações, que possuem seus próprios sistemas de administração patrimonial e gerenciam seus resíduos de maneira independente. Além dessas, há outras instituições que estão vinculadas de alguma maneira à FM, como o Serviço de Verificação de Óbitos da Capital (SVOC) e o Instituto de Medicina Tropical (IMT), entre outros. O IMT passou a ser unidade independente da FM em 2002 e, a registrar seu patrimônio no Sistema MERCURIO em separado desde então. Suas primeiras baixas ocorreram somente em 2008 e, portanto, os dados quantitativos apresentados anteriormente, relativos aos REEE do IMT, correspondem ao período de 2008-2009, com apenas 44 itens baixados. O SVOC também registra seu patrimônio no Sistema MERCURIO separadamente. O IMT encaminha seus REEE baixados para a FM que faz a destinação conjunta com seus REEE.

Desse complexo, apenas o patrimônio da FMUSP consta do levantamento realizado na etapa quantitativa desta pesquisa, correspondente à FM, no Sistema MERCURIO do QS/D. As outras entidades vinculadas à FM possuem seus próprios SIAP e suas baixas não constam dos dados considerados neste estudo. No caso do IMT, A estrutura básica da FM está representada na Figura 6. 
Figura 6 - Estrutura básica da Faculdade de Medicina da USP (FM)

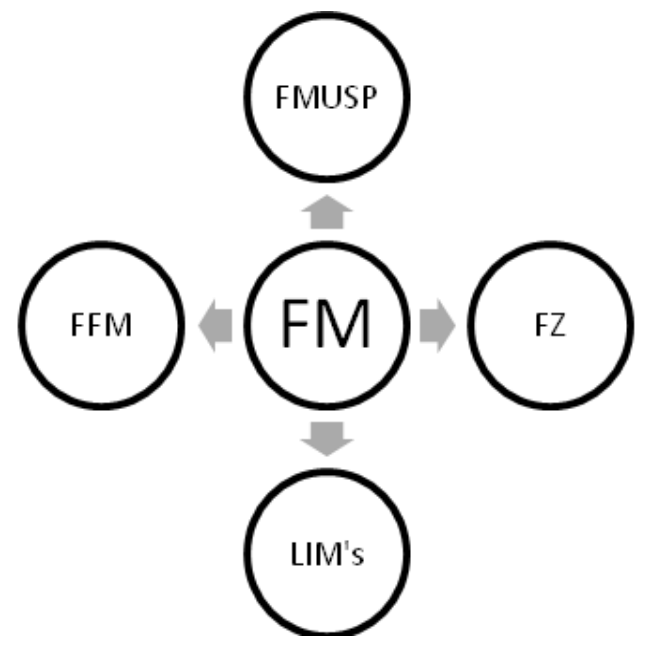

REIDLER, 2011

FMUSP: Faculdade de Medicina da USP

FFM: Fundação Faculdade de Medicina

FZ: Fundação Zerbini - INCOR

LIMs - Laboratórios de Investigação Médica

A análise da situação dos REEE na FM pode esclarecer, em parte, a questão da disparidade dos resultados obtidos no levantamento quantitativo, realizado no Sistema MERCURIO. Os resultados indicam que o volume de REEE descartado no QS/D pode ser muito maior do que o registrado no SIAP. Verificou-se que, na unidade, há um departamento que se ocupa exclusivamente das doações dos bens baixados. Por outro lado, a sucata doada (não patrimoniada), a partir de 2008, passou a ser controlada pelo Departamento de Gestão Ambiental da FMUSP em um registro independente. Esse controle se mostrou um instrumento útil para ajudar a encontrar a resposta à questão apresentada, conforme o resumido na Tabela 9.

Tabela 9 - EEE baixados nos Sistema MERCURIO e os REEE não patrimoniados registrados pelo Departamento de Gestão Ambiental da FMUSP (1999 - 2009)

\begin{tabular}{cccc}
\hline ANO & EEE baixados QS/D & EEE baixados FM & REEE Sucatas doadas FM \\
\hline $\mathbf{1 9 9 9 - 2 0 0 9}$ & 3549 & 418 & - \\
\hline $\mathbf{2 0 0 8 - 2 0 0 9}$ & 1203 & 71 & 2371 \\
\hline
\end{tabular}

*O registro de bens baixados no MERCURIO inclui todas as categorias de REEE

**O registro de sucatas doadas refere-se apenas aos resíduos de informática, incluindo baterias. 
Observou-se que não há controle sobre resíduos de equipamentos de iluminação, de baterias ou de lâmpadas descartadas e, os registros de baterias são raros, o que aponta para um destino inadequado desses produtos. Todas as unidades encaminham as lâmpadas para a reciclagem, mas o armazenamento desse material é inadequado, sem nenhum critério de segregação ou de segurança. O destino mais frequente de outros REEE não patrimoniados é a doação junto com o lixo reciclável, conforme o registrado nas Figuras 7, 8 e 9, que normalmente é doado a cooperativas de catadores, ou é encaminhado ao lixo comum, segundo informações obtidas junto aos setores de Manutenção e Zeladoria. O espaço destinado a bens inservíveis e sucatas é exíguo e não há segregação nem critérios de segurança, conforme o ilustrado nas Figuras 10 e 11.

Figura 7 - REEE perigoso (baterias de chumbo) junto com material reciclável a ser doado para cooperativa de catadores, em uma unidade do QS/D

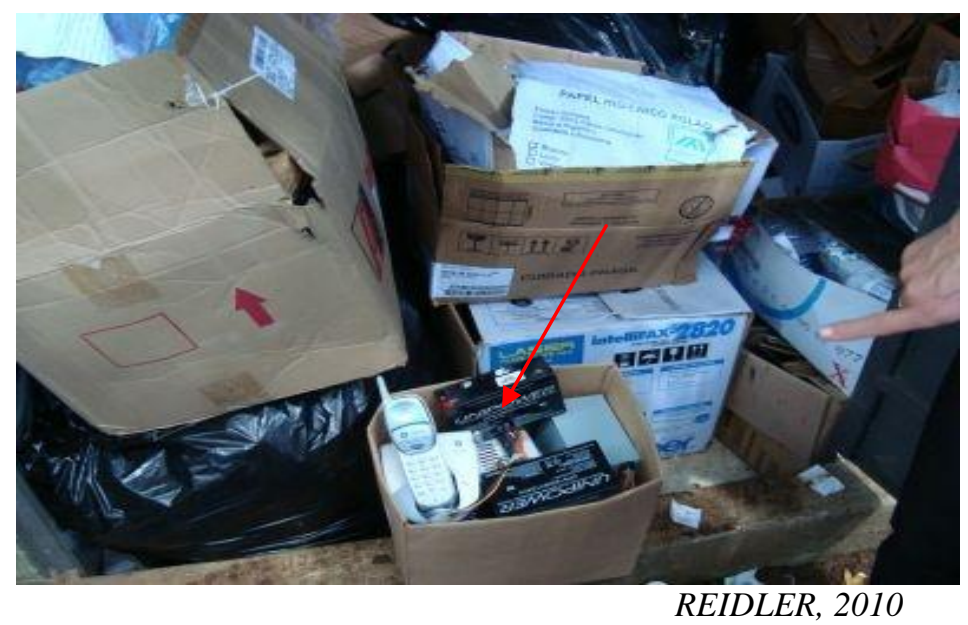

Figura 8 - Depósito de material baixado em unidade do QS/D, à espera de ser doado.

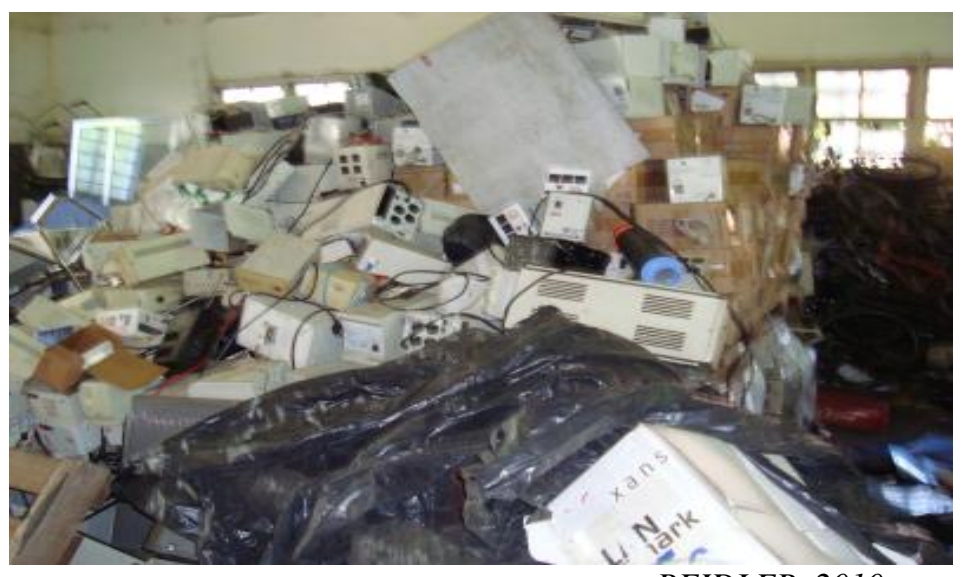

REIDLER, 2010 
Figura 9 - Armazenamento de lâmpadas ao ar livre, sem proteção e junto com outros resíduos, em unidade do QS/D

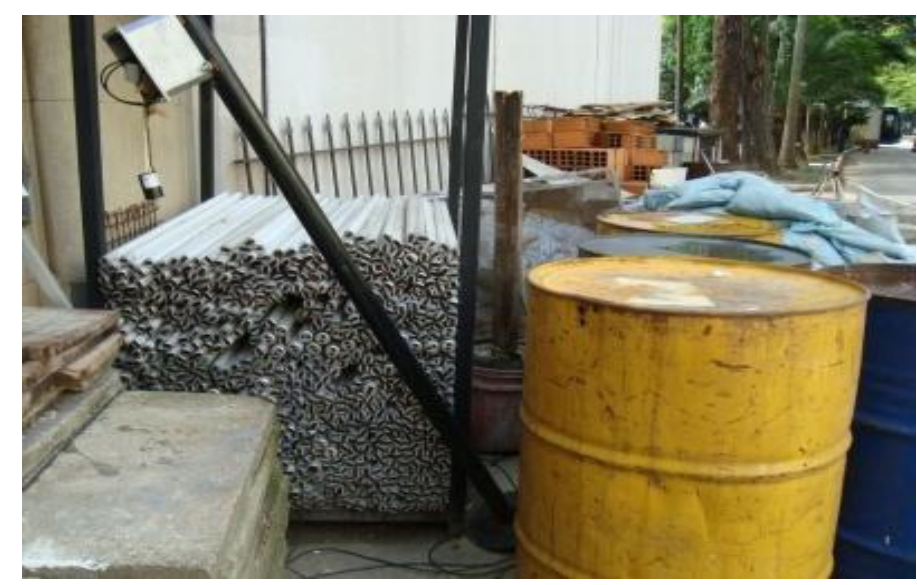

REIDLER, 2010

Figura 10 - Armazenamento temporário de bens inservíveis, para doação em unidade do QS/D

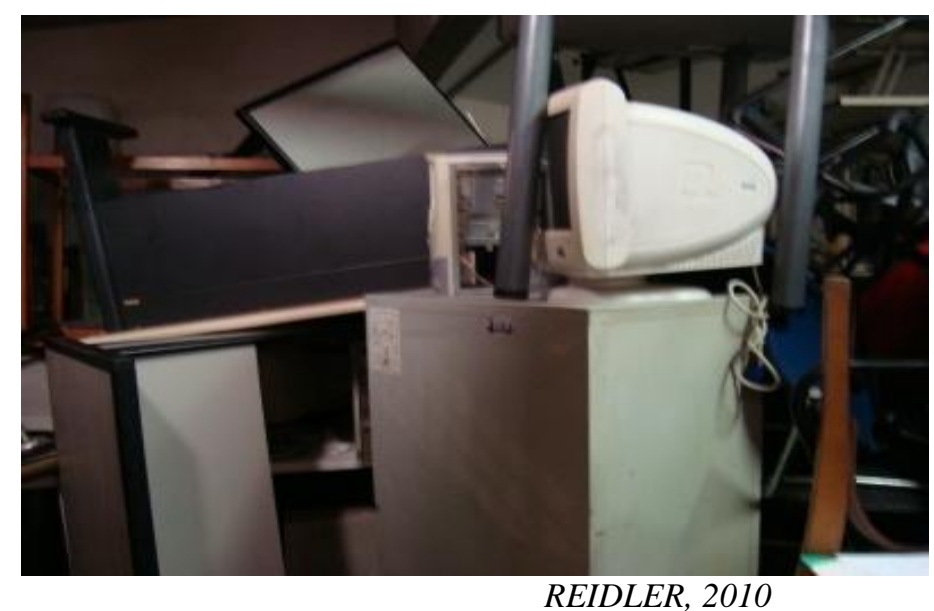

Figura 11 - Armazenamento temporário de sucata em unidade do QS/D

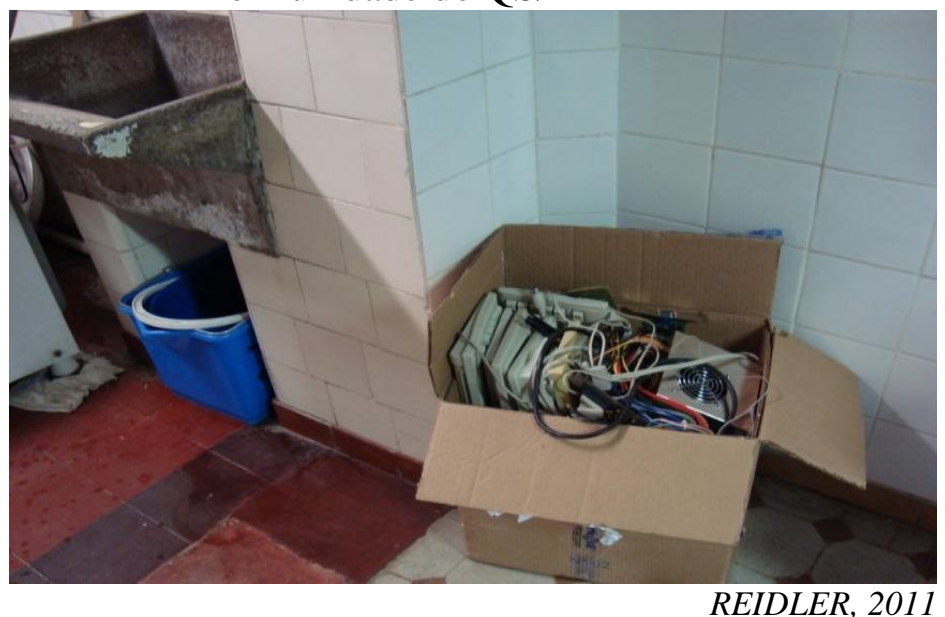




\subsubsection{Transporte dos REEE inservíveis do Campus QS/D da USP até o destino}

Constatou-se que o transporte dos REEE inservíveis do QS/D da USP ao destino é totalmente inadequado e que o manejo desse material é uma questão a ser resolvida em todas as unidades do Campus QS/D, conforme o exemplificado na Figura 12.

Figura 12 - Transporte de sucata em unidade do QS/D

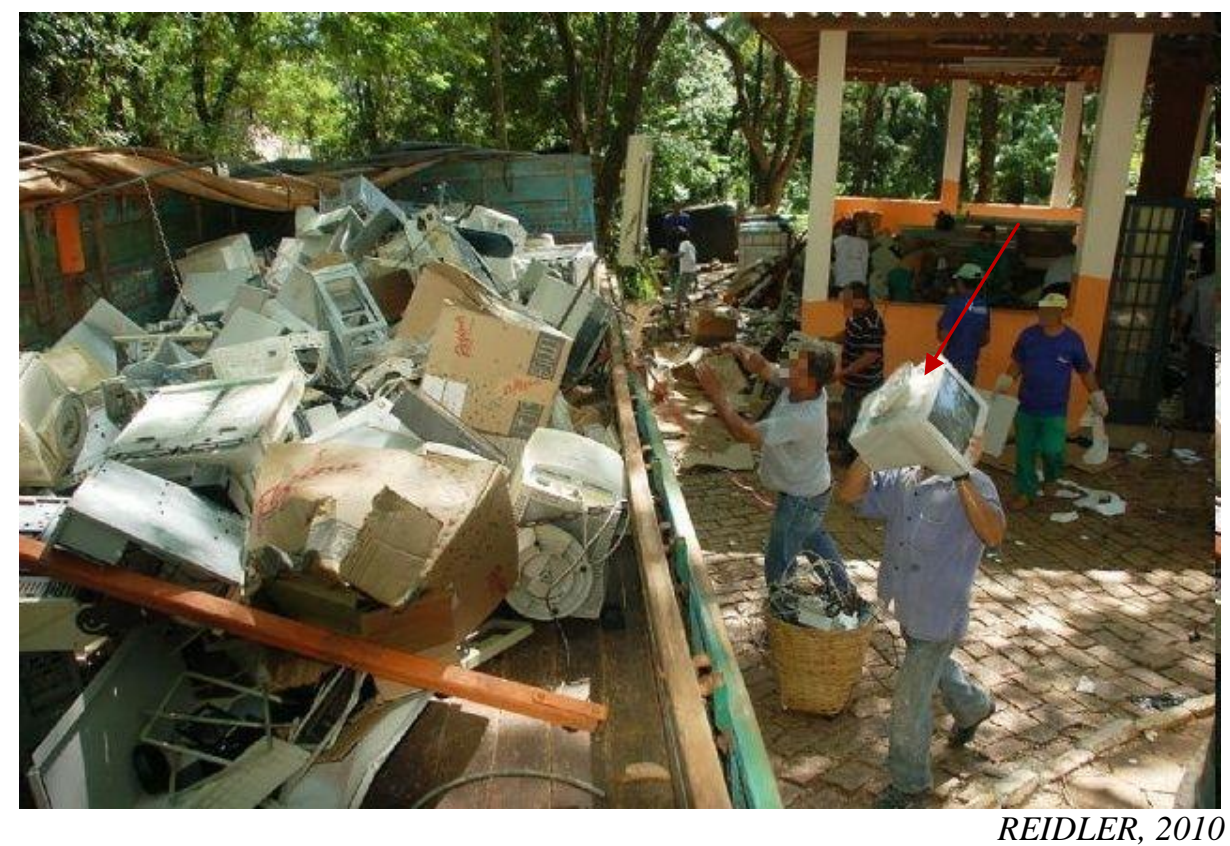

Os REEE, que deveriam ser segregados já no armazenamento, são misturados e jogados sem nenhum cuidado, para dentro da caçamba do caminhão. Entre o material descartado estão, entre outros resíduos perigosos, os monitores de vídeo, que devem ser acondicionados de maneira que não se rompam. O pessoal que maneja esses resíduos não usa nenhum tipo de EPI e não tem ideia dos riscos a que são expostos. Faltam informação e controle, sendo essa uma questão a ser resolvida em todas as unidades. Vale salientar, que mesmo informados de que estavam sendo fotografados, os funcionários seguiram normalmente com suas atividades, o que indica que cumprem ordens e executam suas tarefas de acordo com o que acreditam ser da maneira correta.

\subsubsection{Principais destinos identificados de REEE do Campus QS/D da USP}

Segundo as informações obtidas, os principais destinos identificados foram:

- Reutilização - em outras unidades ou em instituições públicas

- Devolução - às instituições de origem 
- Repasse - a outras instituições ou a órgãos da Administração Pública*

- Doação - a entidades filantrópicas sem fins lucrativos

- Reciclagem (USP RECICLA) - doação a cooperativas de reciclagem

- Comercialização - sucateiros

- Fundo Social de Solidariedade do Estado de São Paulo (FUSSESP) - leilão, sucateiros.

*Outras instituições ou a órgãos da Administração Pública: postos de saúde, escolas publicas, prefeituras municipais, órgãos públicos estaduais e municipais, Polícia Militar do Estado de São Paulo e Corpo de Bombeiros, entre outros, com a finalidade de reutilização.

\subsection{INVESTIGACÃO DO FLUXO E DESTINO DOS REEE DO QS/D - USP}

Na USP, o material baixado do patrimônio só pode ser doado a instituições públicas ou sem fins lucrativos, cadastradas para esse fim. Caso não haja interesse por parte de outras unidades da USP, há preferência por entidades filantrópicas que aceitem qualquer tipo de doação e que retirem o material o mais rápido possível, para liberar o espaço. Após os procedimentos de baixa patrimonial, cada unidade da organização tem autonomia para definir a destinação de seus bens inservíveis (GEFIM, 2004), nos quais estão incluídos os REEE. O gerenciamento desses resíduos é, geralmente, descentralizado e realizado de forma independente, o que pode resultar em um sistema de gestão com maior dificuldade de controle. Depois que o material deixa a instituição, não há acompanhamento do fluxo e do destino.

Constatou-se que se reconhecem os impactos causados pelos REEE e algumas ações isoladas são tomadas para minimizá-los. Na gestão interna desses resíduos, atua-se no sentido de cumprir as normas internas, os estatutos da instituição e a legislação pertinente. Busca-se com a doação de seus bens, a sustentabilidade social, mantendo uma postura ética, ao mesmo tempo em que se pratica a solidariedade e a inclusão social. Os destinatários, por outro lado, buscam somente a sustentabilidade econômica. A gestão externa dos REEE não existe e, consequentemente, a sustentabilidade ambiental também não. Não foi demonstrado interesse na reutilização de REEE, por parte dos usuários, em nenhuma unidade estudada. 


\subsubsection{Visitas aos locais de destino dos REEE do Campus QS/D da USP}

Com o objetivo de investigar os locais de destino dos REEE gerados, além de dados complementares aos obtidos no diagnóstico foram realizadas visitas técnicas pré-agendadas às seguintes instituições, que são utilizadas como destino pelas unidades estudadas:

- ALIVI - Aliança Pela Vida: ONG - entidade filantrópica sem fins lucrativos, mantida por doações de particulares, para assistência a portadores do vírus da AIDS, socialmente necessitados. Aceita somente equipamentos reutilizáveis e em bom estado.

- APAE- Associação de Pais e Amigos dos Excepcionais: ONG - organização social sem fins lucrativos, dedicada a atender pessoas com deficiência intelectual. Aceita somente equipamentos reutilizáveis e em bom estado.

- Casas André Luiz: ONG - entidade filantrópica sem fins lucrativos, que atende a pessoas com deficiência mental, com ou sem deficiência física associada. Aceita qualquer tipo de doação. Vende os equipamentos em bom estado no Bazar Mercatudo e o restante a sucateiros.

· Lar e Escola São Francisco: ONG - instituição filantrópica sem fins lucrativos, dedicada à assistência a pessoas com deficiências, visando à recuperação física, educacional e integração social. Vende os equipamentos em bom estado no Bazar Samburá e o restante a sucateiros.

· FUSSESP - Fundo de Solidariedade e Desenvolvimento Social e Cultural do Estado de São Paulo, órgão do setor público vinculado à Secretaria da Casa Civil. Conta com o apoio essencial do setor público, com doação de materiais inservíveis. Aceita qualquer tipo de doação e comercializa a sucata em leilão, por lotes. A renda é destinada a projetos sociais específicos.

Para identificação dos REEE recebidos e de sua origem, das condições locais de trabalho, manipulação, beneficiamento, possíveis formas de recuperação e destinação de materiais após a triagem nos locais receptores, utilizou-se uma planilha do tipo check list (ANEXO II). Quando possível, foi efetuado registro fotográfico. 


\subsubsection{Procedimentos nos locais de recebimento dos REEE doados}

Todas as instituições visitadas recebem resíduos de todas as categorias de REEE presentes no check list (APÊNDICE II) e efetuam o registro dos materiais recebidos e de sua origem. A maioria é proveniente de doações de pessoas físicas, mas recebem também de empresas particulares e de instituições públicas. Das cinco instituições destinatárias visitadas, as quatro ONGs informaram que realizam uma triagem dos REEE recebidos e um teste para verificar o funcionamento. Quando estão em condições de uso, podem ser reutilizados no próprio local, ou ser vendidos no estado em que foram recebidos, ou ainda repassados para programas de inclusão digital. No caso do equipamento estar avariado, o reparo pode ser realizado em três das ONGs visitadas, que também fazem a desmontagem, quando os equipamentos não são reutilizáveis.

Nas ONGs APAE, Casas André Luiz, Lar Escola São Francisco, instituições que reparam e/ou fazem a desmontagem dos REEE recebidos, as peças e os componentes são segregados e armazenados corretamente em recipientes rígidos ou em bags, para posterior comercialização. Os materiais que estiverem em condições de uso são reutilizados localmente, para substituir peças e reparar outros equipamentos avariados. Essa atividade, conhecida como canibalização, por um lado pode prolongar a vida útil de outros EEE, mas por outro, geram rejeitos que, quando não podem ser vendidos, são descartados junto com o lixo comum. A ALIVI só aceita equipamentos em boas condições de funcionamento.

Em princípio, em nenhuma entidade visitada há rejeito, pois todo o material recebido é comercializado para angariar fundos. No entanto, a maioria dos EEE recebidos consiste em material não reutilizável, como monitores de vídeo, equipamentos de refrigeração e de iluminação, equipamentos médicos e outros resíduos perigosos, que necessitam de descontaminação antes do descarte em aterros sanitários, fato que não ocorre em nenhum caso. Situação pior foi a verificada no órgão público FUSSESP. A maioria das instituições públicas estaduais, entre elas o Hospital das Clinicas da FMUSP e a Faculdade de Medicina e Secretarias de Estado, são obrigadas a enviar seus bens inservíveis para lá.

Na FUSSESP, o material recebido é separado por tipo e vendidos em lotes de grandes quantidades. Não se realiza nenhum tipo de teste de funcionamento para reutilização. $\mathrm{O}$ gerente informou que não há rejeitos entre o material doado, pois em cada lote vendido é incluída uma quantidade de refugo. A responsabilidade de descartar o que não for reciclável é 
repassada para o comprador. O armazenamento não obedece a nenhum critério de segurança, para que monitores de vídeo e outros REEE perigosos não se rompam. As Figuras 13 e 14 ilustram as condições de armazenamento do material, recebido pela instituição pública, separados por lotes.

Figura 13 - Armazenamento de sucata doada na FUSSESP.

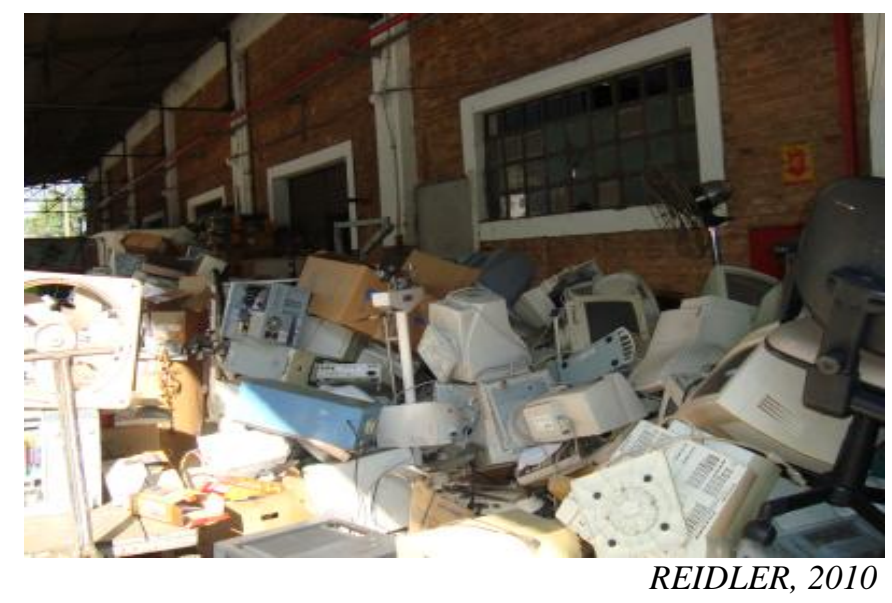

Figura 14 - Armazenamento temporário de lotes de sucata para leilão na FUSSESP.

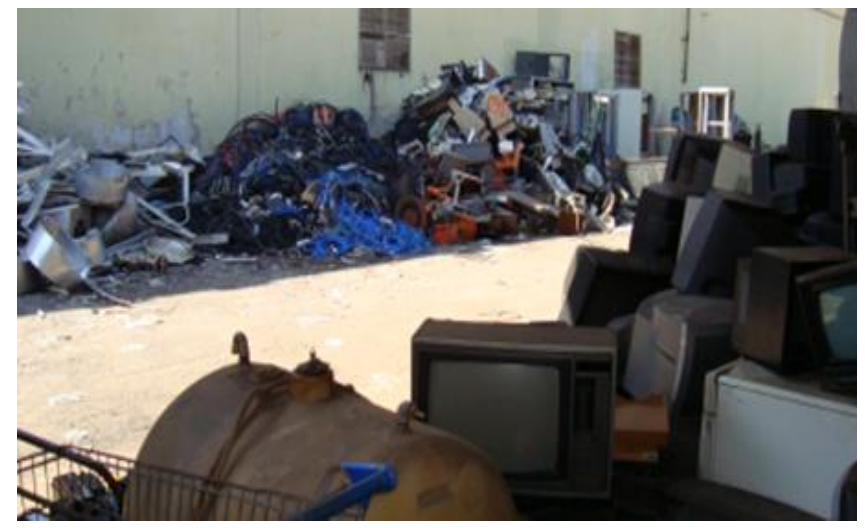

REIDLER, 2010

Os REEE de refrigeração, assim como os de ar condicionado, contêm gases de refrigeração e espuma de poliuretano, impregnada com CFC, os quais devem ser segregados e tratados de forma diferenciada, por pessoal capacitado para a operação. Nas visitas aos locais de destino, verificou-se que esse material é rompido sem nenhum cuidado, para retirar a parte reciclável conforme se pode observar nas Figuras 15 a 17 e os rejeitos são encaminhados para disposição em aterro (não se especificou de que tipo). 
Figura 15 - Armazenamento temporário de REEE de refrigeração, em lotes para leilão, na FUSSESP.

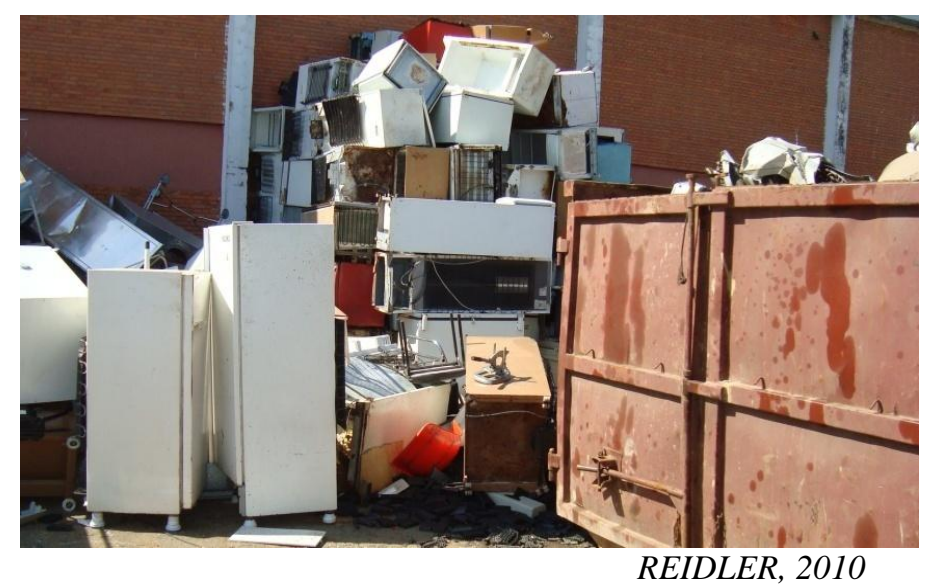

Figura 16 - Carregamento de lotes de sucata e REEE contendo gases de refrigeração, preparados para o transporte.

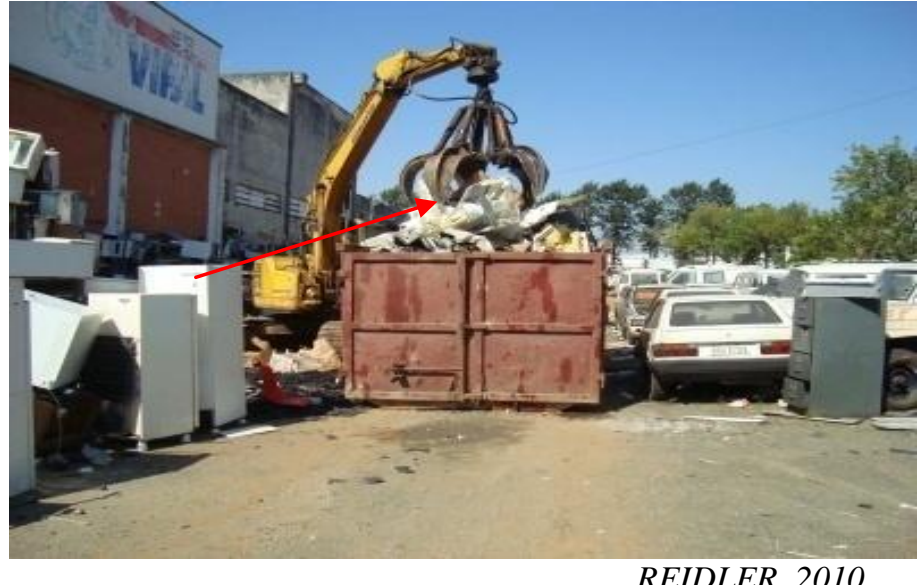

Figura 17 - Transporte de sucata de REEE de refrigeração contendo espuma de poliuretano impregnada com CFC.

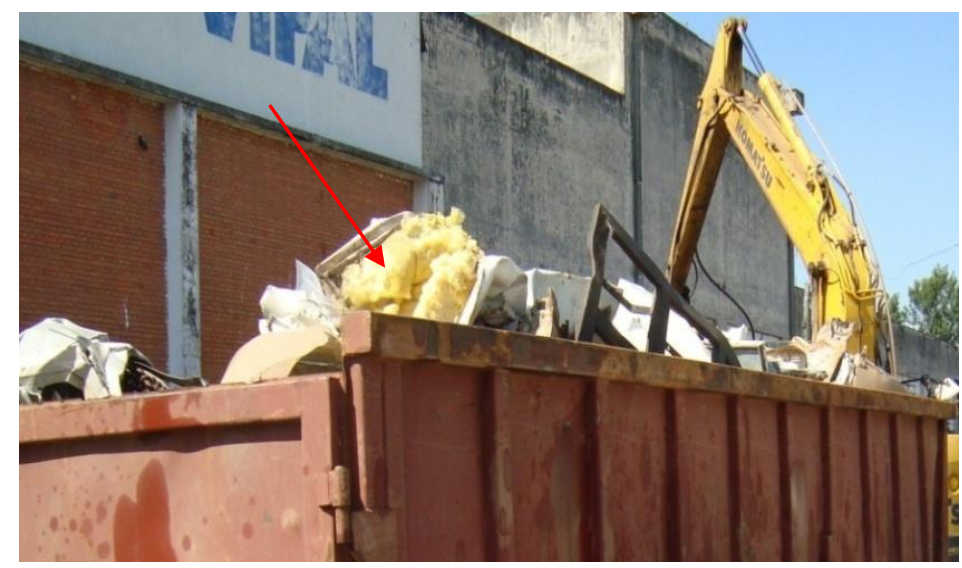

REIDLER, 2010 


\subsubsection{Condições locais e de trabalho nos locais de destino}

O registro fotográfico das condições de trabalho não foi permitido, mas essas não variaram muito nas ONGs visitadas, nas quais se verificou a existência de ventilação, boa iluminação e a presença de extintor de incêndio. No entanto, nenhum dos locais visitados conta com saída de emergência. $\mathrm{O}$ uso de luvas é frequente, mas não obrigatório, no manejo dos REEE recebidos, enquanto os óculos e máscaras são raros. Não foi observado o uso de gorros, máscaras, aventais e botas em nenhuma das instituições visitadas.

O Fundo Social de Solidariedade do Governo do Estado de São Paulo apresentou péssimas condições ambientais de trabalho, de um modo geral. Ali, um galpão fechado, mal ventilado e com iluminação precária, abriga os lotes prontos para serem vendidos e, uma área aberta, onde material recebido a espera de triagem, assemelha-se a um deposito de lixo. O local não oferece as mínimas condições ambientais para o bem estar, a segurança e a saúde dos trabalhadores, que não recebem nenhum tipo de informação sobre riscos ou utilizam algum tipo de Equipamento de Proteção Individual (EPI). As Figuras 18 e 19 ilustram como é o ambiente de trabalho na FUSSESP.

Figura 18 - Armazenamento temporário de REEE em local aberto na FUSSESP

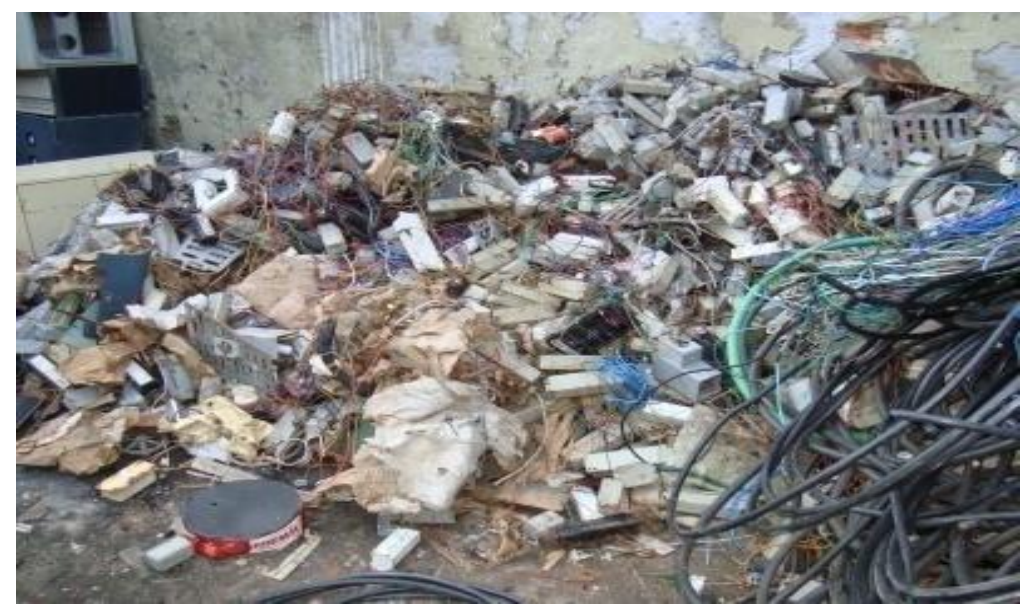

REIDLER, 2010 
Figura 19 - Armazenamento temporário de REEE doado, em local aberto na FUSSESP.

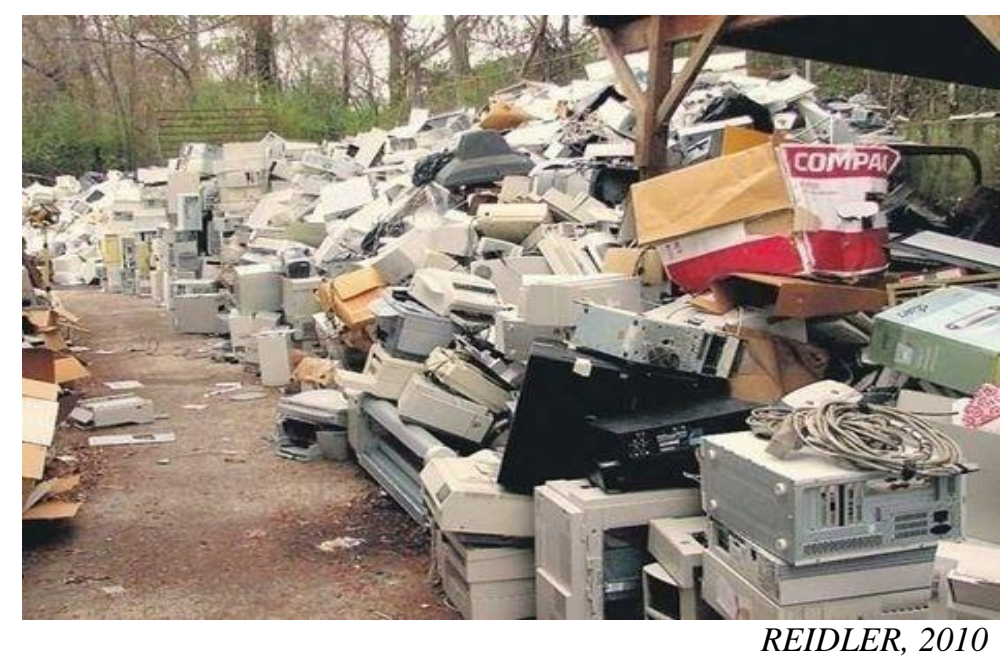

\subsubsection{Capacitação}

Nas ONGs visitadas, os entrevistados informaram que os funcionários recebem algum tipo de capacitação para trabalhar com os REEE. Observou-se que essa é focada em como segregar o material por tipo, desmontar e armazenar os EEE. Em alguns casos, há técnicos que reparam os EEE. No entanto, não se verificou a existência de informação sobre riscos à saúde ou algum tipo de educação ambiental. Na instituição pública FUSSESP, não há nenhum tipo de capacitação ou de prevenção.

\subsubsection{Outros destinos de REEE visitados}

Com o objetivo de aprofundar o conhecimento a respeito do fluxo dos REEE do QS/D da USP, foram realizadas visitas a quatro recicladoras de REEE, indicadas como principais destinos, durante as visitas às instituições receptoras de REEE da USP.

CEDIR - Centro de Descarte e Reuso de Resíduos de Informática - CCE: surgiu em 2009, como projeto do CCE da USP para dar uma solução sustentável aos REEE gerados nas unidades da USP, localizadas na Capital. A ideia é interessante do ponto de vista de gestão integrada dos REEE institucionais. Entretanto, por questões administrativas internas, falta de planejamento e de recursos humanos, após várias tentativas, tem operado parcialmente. Cada unidade da USP segue destinando seus resíduos individualmente, não havendo nenhuma integração dessas atividades com as demais. Segundo as informações obtidas, o CEDIR está 
passando por uma reestruturação, para tentar atingir os objetivos para o qual foi criado e recebe EEE de TIC de algumas unidades. Está equipado com ferramentas, empilhadeira, carrinho para transporte de material e balança para pesagem com capacidade de até $2000 \mathrm{~kg}$ (Fig. 23) para executar as seguintes operações, esquematizadas na Figura 20:

\section{Figura 20}

Etapas de operação do projeto CEDIR:

a) Coleta e Triagem:

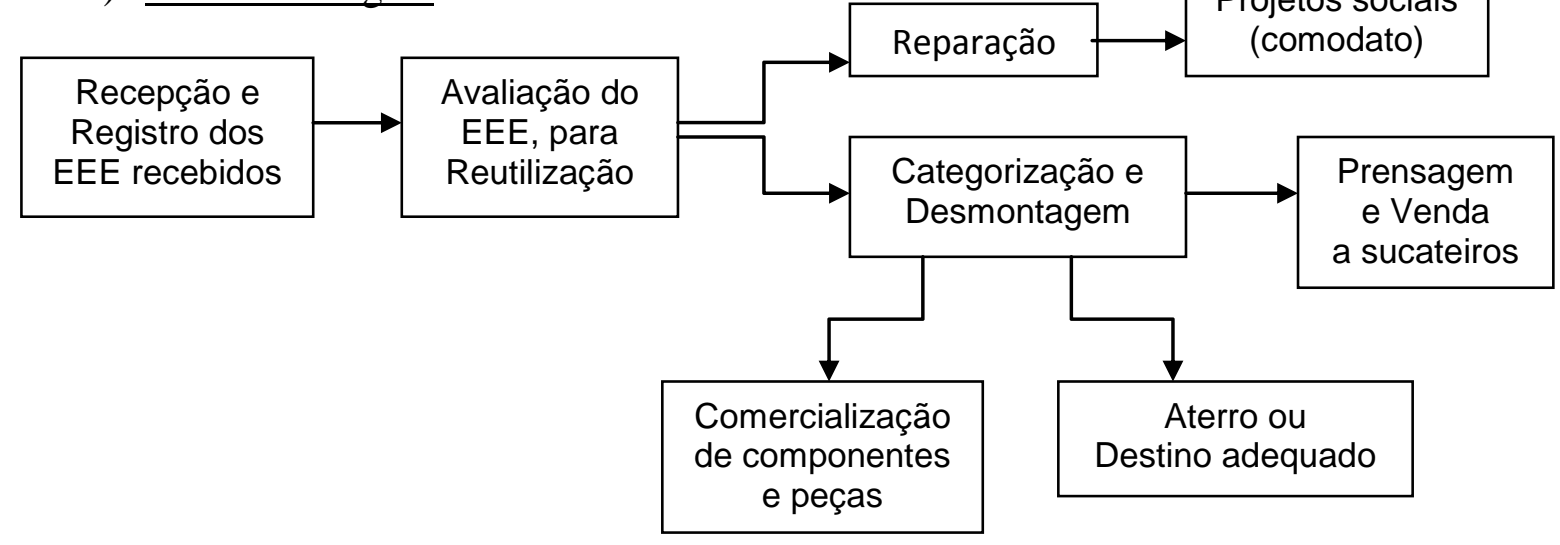

O comodato é adotado como medida de prevenção, na tentativa de fazer com que o EEE retorne ao CEDIR, para ser destinado corretamente. Nenhuma dessas etapas ou informações obtidas na visita foi verificada na prática. O CEDIR não recicla materiais. Os materiais do mesmo tipo são descaracterizados e prensados. A compactação é realizada com o objetivo de redução do volume (Figura 21) e, consequentemente, dos custos de transporte até as recicladoras. Os monitores de vídeo devem ser armazenados e transportados de maneira que não se rompam, para evitar impactos negativos ao ambiente. Após a baixa dos REEE no sistema MERCURIO, a unidade da USP pode agendar por telefone a coleta do material. Os funcionários usam EPIs e recebem capacitação prévia para realizar a atividade. Observou-se que, na prática, equipamentos sem valor comercial, como os monitores de vídeo, são armazenados e transportados sem cuidado, com risco de ruptura e liberação de substâncias tóxicas e de impactos no ambiente e na saúde do trabalhador conforme se pode observar na Figura 22. 
Figura 21 - Prensa de REEE no CEDIR

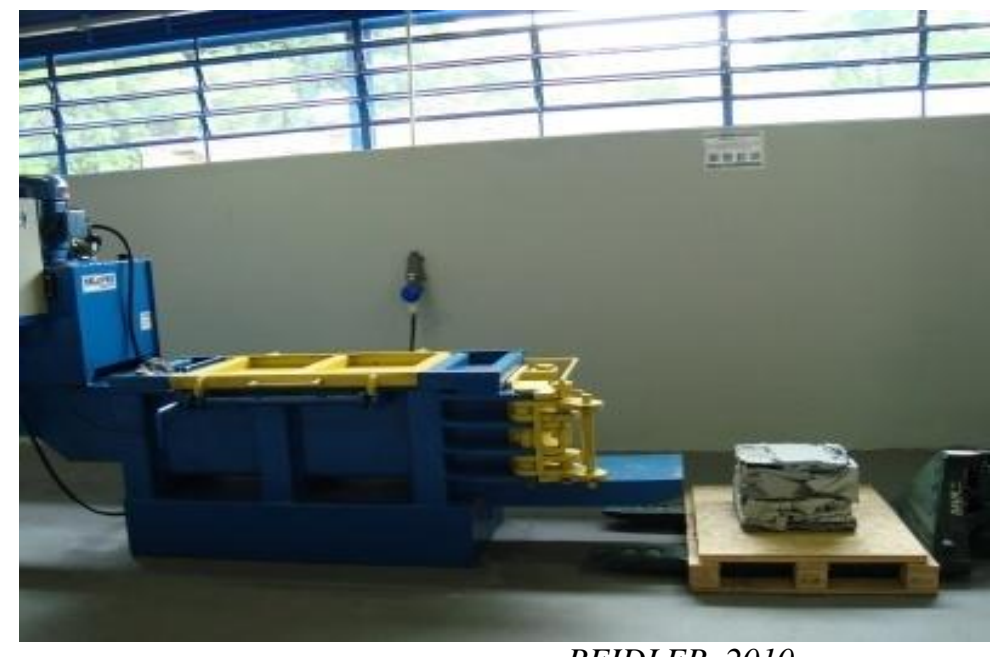

REIDLER, 2010

Figura 22 - Armazenamento de monitores no CEDIR.

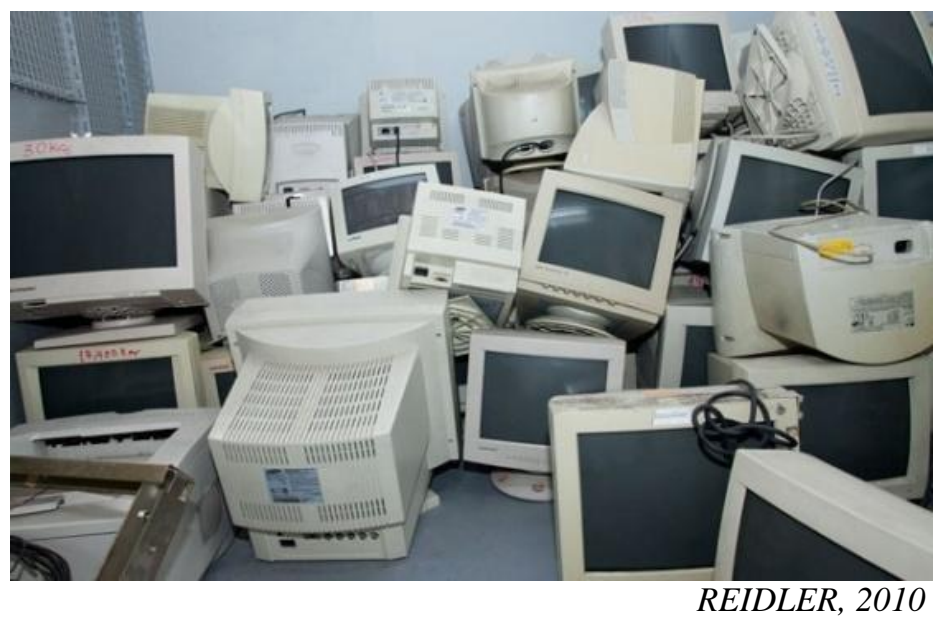

Figura 23 - Balança para pesagem dos REEE no CEDIR

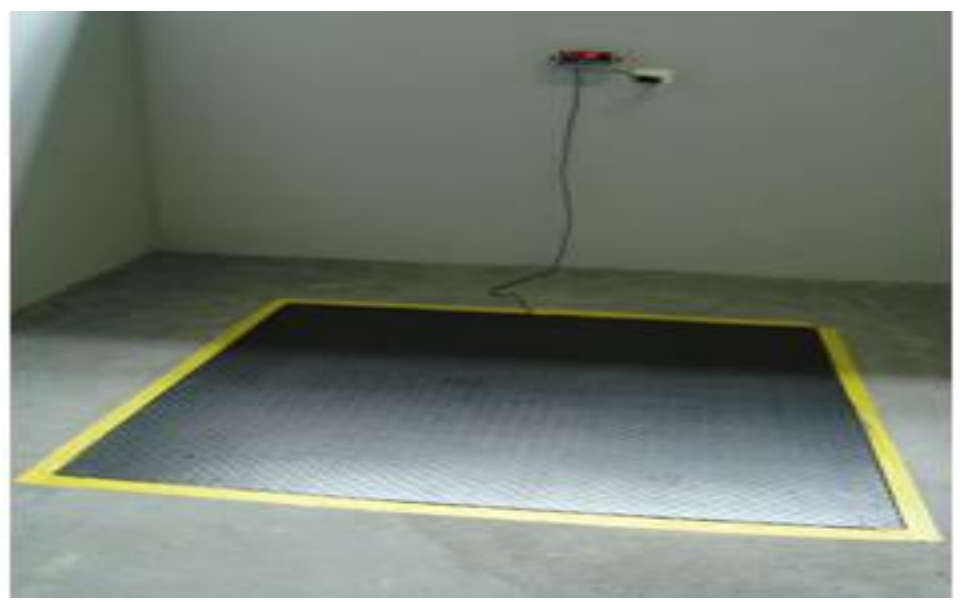

REIDLER, 2010 
c) Reciclagem: os materiais separados por categorias são armazenados até o seu recolhimento por empresas de reciclagem, devidamente credenciadas pela USP e especializadas em materiais específicos, como plástico, metais ou vidro. Alguns resíduos são comercializados, enquanto outros têm sua coleta e reciclagem cobradas, como no caso de monitores de vídeo e lâmpadas, entre outros. Dessa forma, segundo informação obtida, "não sobram rejeitos". Essa ideia do CEDIR e de outras instituições, de que não geram resíduos pode ser tendenciosa e não reflete a realidade. $O$ que ocorre, pode ser uma transferência de responsabilidade para as recicladoras, que apesar de emitirem um certificado de destino adequado dos REEE, não o especificam e não relatam o que acontece com os rejeitos. Segundo informações recebidas na visita, o Centro somente é economicamente viável, se receber uma quantidade de REEE mensal equivalente a, no mínimo, $500 \mathrm{~kg}$, para equilibrar receita e despesas. O CEDIR atua como intermediário no fluxo dos REEE e não possui licença ambiental para tratar ou reciclar resíduos perigosos.

COOPERMITI: cooperativa de catadores pioneira no Brasil e na cidade de São Paulo, que recolhe e recebe todo tipo de REEE, inclusive baterias e pilhas esgotadas. Começou a operar em 2010 e segundo as informações recebidas, o material recebido é desmontado e enviado para a reciclagem ou outro destino "adequado" (APÊNDICE III), de forma que seja possível a sua rastreabilidade. A entidade sem fins lucrativos tem o objetivo de gerar empregos e preservar o meio ambiente. Promove cursos de capacitação e de educação aos funcionários cooperados. Possui uma parceria com a Prefeitura Municipal de São Paulo e com o Departamento de Limpeza Urbana (LIMPURB) da Capital.

Segundo informações fornecidas por um diretor, durante visita técnica, Tecnicamente, a COOPERMITI tem recebido o apoio do CEDIR da USP. A Prefeitura Municipal de São Paulo financia o aluguel do galpão e os demais investimentos com equipamentos e ferramentas. Os REEE recebidos consistem, principalmente, em monitores de vídeo e fontes de computador. Esses resíduos têm como origem, principalmente, estabelecimentos de serviços e pessoas físicas que solicitam a retirada desses materiais. Os REEE recebidos passam por pesagem, teste de funcionamento, eventual reparação, desmontagem, segregação, classificação, prensagem dos metais e armazenamento. Os equipamentos considerados aptos para reutilização após esses processos, sobretudo computadores, monitores e fontes são comercializados ou doados para as instituições de caridade que destinam seus REEE para a COOPERMITI, em base de troca por outros REEE. As pilhas e baterias, lâmpadas 
fluorescentes e os TRC (monitores e televisores), são considerados rejeitos e são encaminhados para reciclagem. O material não reciclável (refugo) é encaminhado para aterro, junto com o lixo comum. A cooperativa possui uma área bem organizada, destinada à triagem, desmontagem e armazenamento dos REEE recebidos. Verificou-se que seus trabalhadores usam uniformes e EPIs, conforme se pode observar na Figura 24.

Figura 24-COOPERMITI - Cooperativa de Reciclagem de REEE

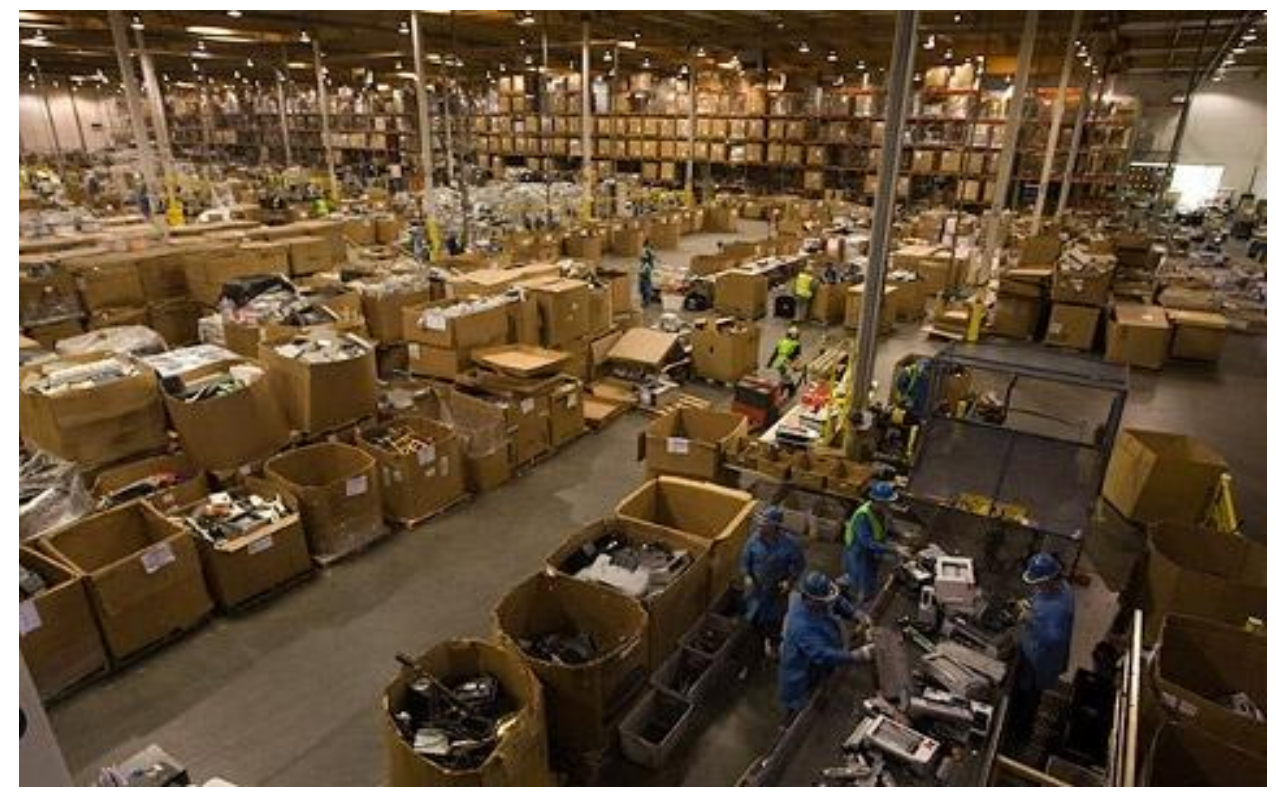

Fonte: COPERMITI, 2011.

Centro de triagem e armazenamento de REEE no Município de São Paulo.

Observou-se grande quantidade de Tubos de Raios Catódicos (TRC) armazenada. Desse tipo de componente informaram que são retirados para comercialização os fios de cobre e placas e carcaça de plástico ABS. Um dos destinos informados para os TRC é a empresa ATIVA, que cobra R \$ 2,00 por unidade para o tratamento e destinação. No caso dos TRC, estudam a possibilidade de processamento/beneficiamento desse material a fim de evitar custos e se possível comercializar os materiais obtidos. Mas, pode demorar, pois para esse tipo de atividade há necessidade de licença do Órgão Ambiental, por se tratar de resíduo perigoso. Pilhas e baterias têm chegado à COOPERMITI em pequena quantidade e estão sendo armazenadas em um recipiente apropriado, para enviar aos coletores do Papa-Pilhas ou de algum programa equivalente. $\mathrm{O}$ diretor informou que o gerenciamento de monitores de vídeo, pilhas e baterias, entre outros, não é economicamente sustentável, pois esse material não tem valor comercial e sua reciclagem e/ou a disposição final são cobradas. 
A Cooperativa atua como intermediária no fluxo do REEE e possui diversos parceiros para a compra de seus materiais processados, entre esses a LATAR, a LORENE e a RECICLO. Dependendo da quantidade, os compradores retiram o material sem custo, ou a COOPERMITI leva ao local de destino, caso não atinja a quantidade mínima estabelecida para a coleta. A ideia do projeto é boa, mas segundo as informações obtidas na visita, a cooperativa necessita de mais apoio financeiro para ser autossustentável.

RECICLO: compõe-se de duas empresas familiares que atuam na área de prestação de serviços e manufatura reversa. Na visita, as instalações em operação foram verificadas, mas foram permitidos registros fotográficos e fornecidas as seguintes informações:

I. RECICLO AMBIENTAL: atua na prestação de serviços, realizando os seguintes serviços: avaliação, adequação, captação, armazenamento, descaracterização, separação, destinação ambiental e socialmente responsável, certificado de destinação com anexo de rastreabilidade, como todos os atores da cadeia, todos as materiais recebidos, tudo que foi gerado pela manufatura reversa com as quantificações e a destinação de cada material gerado (nota fiscal, local, data, quantidade, exportação).

II. $\quad$ RECICLO METAIS: atua na área da manufatura reversa, cujo objetivo é liberar os diferentes materiais e direcioná-los para o processamento final, sendo intermediários no processo. Recebem pequenos eletrodomésticos, equipamentos da linha cinza (informática e telecomunicações) e equipamentos da linha marrom, como áudio e vídeo. Não são recebidos equipamentos da linha branca (grandes eletrodomésticos). Realizam as operações de desmontagem, segregação e identificação do material. Embora não façam a reciclagem e atuem como intermediários no fluxo dos REEE, classificam-se como recicladores. Processam cerca de 50 t/ mês, de materiais diversos, principalmente placas de circuito impresso (40 t/ mês), mas tem capacidade para até 80 t/ mês, em uma área de $1000 \mathrm{~m}^{2}$ e contam com 12 funcionários. Possuem um moinho para segregação de fios e cabos, que separa o cobre do plástico e tem um ímã para separar o material ferroso.

Segundo as informações obtidas nas visitas, quanto maior o grau de segregação, maior valor agregado adquire o material. Para os equipamentos de informática, a taxa de reciclagem é de $90 \%$. No entanto, teclados têm baixo valor comercial. As placas são separadas por qualidade e as de telecomunicações são as mais valorizadas, por seu teor de metais. Os computadores possuem $10 \%$ de seu peso correspondente a placas de circuito integrado. 
Quanto aos monitores TRC, a empresa já adquiriu uma máquina que realiza a separação da tela que contem chumbo, mas ainda não está operando e os tubos estão sendo armazenados. Alguns materiais, como plásticos não identificados e fitas magnéticas, entre outros, não têm valor comercial e são considerados rejeitos, são enviados ao Aterro Sanitário (ESSENCIS), que cobra por seus serviços, mas em termos econômicos, o saldo é positivo. Possuem parcerias com diversas empresas, internacionais e nacionais para recuperação de materiais.

A empresa possui licença de operação da CETESB, cadastro técnico federal do IBAMA e licença da SABESP, de não contaminação das águas subterrâneas. Quanto à parte ocupacional, possuem um técnico de segurança e uma empresa presta consultoria na área saúde do trabalhador, que realiza exames médicos regulares nos funcionários. Foi observado o uso de EPIs, como máscaras, luvas, óculos, capacete, botas e macacão.

SILCON AMBIENTAL: atua desde 1995 em serviços e soluções para o gerenciamento e destinação final de resíduos e na produção de biomassa. Tem sede na Capital de São Paulo e unidades instaladas em várias cidades do interior do Estado e uma em Cachoeiro de Itapemirim (ES). Segundo as informações recebidas durante a visita, o projeto da empresa prevê a implantação de uma unidade de revalorização de REEE, com o objetivo de destinar corretamente esses resíduos de processos de reciclagem de materiais, recuperando as matérias primas para sua reinserção no processo de produção. O processo deve compreender desde a conferência e a retirada dos materiais, até a desmontagem e/ou descaracterização de produtos inservíveis ou fora de linha, até a destinação de resíduos gerados. A empresa inclui no certificado de destinação dos REEE, um laudo técnico com registro fotográfico das etapas do processo, para que a rastreabilidade desses resíduos seja possível. Por outro lado, materiais que não podem ser reciclados, como cinescópios, capas de celulares, etiquetas adesivas e toners são descontaminados e destinados a aterro. A capacidade atual de processamento é de 500 ton./mês e para os equipamentos de informática a reciclagem chega a 94\%. Recebem todos os tipos de REEE de empresas, fabricantes e escritórios, apenas pessoas jurídicas. Os trabalhadores são todos treinados e usam todos os EPIs necessários. Possuem as licenças de operação necessárias. Já parte dos REEE, que não é processada pela empresa, é exportada para países que já dominam a tecnologia para a reciclagem desses materiais. 


\subsubsection{Fluxo dos REEE gerados no Campus QSD da USP}

A identificação do fluxo dos REEE gerados no QS/D apoiou-se na literatura e em informações provenientes de entrevistas informais, workshops, questionários, visitas técnicas, e registros fotográficos, quando permitidos. As visitas, para investigação dos impactos decorrentes do fluxo dos REEE foram realizadas conforme as necessidades indicadas nas análises dos dados obtidos na etapa anterior. Identificou-se a existência de três fluxos principais dos REEE gerados no QS/D da USP, conforme sua origem e status patrimonial, durante sua vida útil, conforme o resumido na Figura 25.

Figura 25 - Principais fluxos identificados de REEE gerados no QS/D da USP

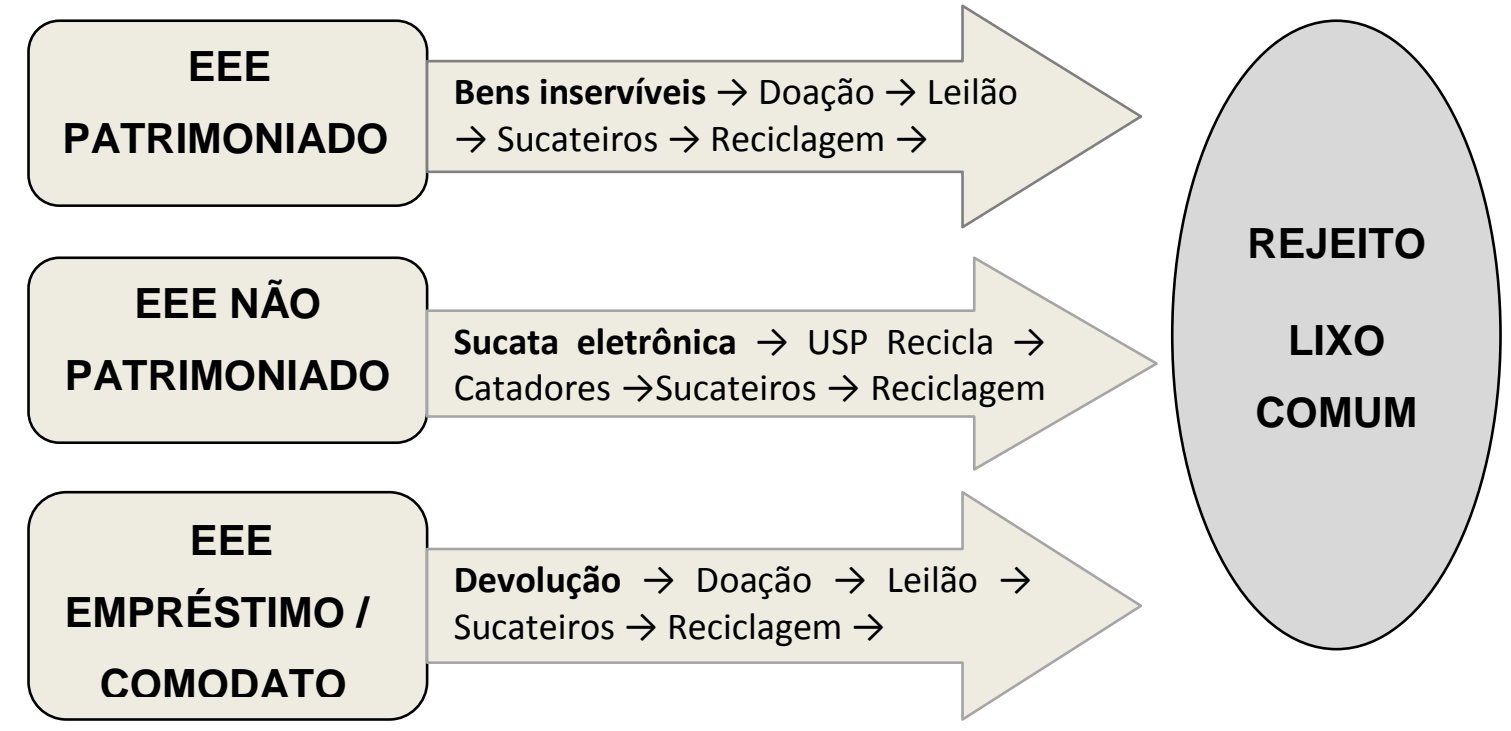

Ao sofrerem processo de baixa no SIAP, os EEE patrimoniados adquirem o status de “bens inservíveis". Esses não são considerados REEE e, portanto, são destinados à doação a outras instituições públicas ou a instituições filantrópicas sem fins lucrativos. Segundo informações coletadas nas visitas, estima-se que apenas $2 \%$ do material doado têm condições de uso ou de recuperação. O restante é desmontado e os componentes, peças e materiais com algum valor comercial são vendidos em lotes a sucateiros. O rejeito é descartado junto com o resíduo comum. Os EEE não patrimoniados, são descartados diretamente no lixo comum ou são vendidos como sucata quando possuem algum valor agregado. Os EEE provenientes de empréstimo ou de comodato são devolvidos à instituição de origem e seguem a mesmo caminho inverso da doação. É interessante observar que, apesar dos fluxos serem distintos de acordo com sua origem, sempre sobra o rejeito, que nem sempre terminará em disposição final adequada. Não há monitoramento desses fluxos nem rastreabilidade desses resíduos. 


\subsection{APRESENTAÇÃO DO DIAGNÓSTICO AOS ENVOLVIDOS COM A QUESTÃO DOS REEE NO CAMPUS QS/D DA USP}

Os convidados para o workshop realizado para a apresentação do diagnóstico já haviam sido contatados e consultados anteriormente, de maneira informal, em seus locais de trabalho. Houve uma participação de $100 \%$, com o comparecimento de todos os convidados. Todos os presentes demonstraram muito interesse em participar do processo de gestão integrada dos REEE no Campus QS/D da USP. Após a apresentação do diagnóstico, foram divididos em cinco grupos, de acordo com a área de atuação em suas respectivas unidades: Administração, USP Recicla, Informática, Manutenção e Patrimônio. Os grupos de trabalho (GT) foram incentivados a debater as questões apresentadas em um roteiro de discussão (APÊNDICE I), monitorados pela pesquisadora e por alguns colaboradores. Os resultados desta atividade confirmaram os problemas e as necessidades identificadas nas visitas às unidades. Observou-se o anseio geral por informação, pois um dos principais entraves para a gestão dos REEE parece ser a falta de conhecimento dos procedimentos a serem adotados. Houve unanimidade na opinião de que os trabalhos iniciados nessa reunião deveriam ter continuidade, pois as reuniões periódicas dos GTs poderiam auxiliar em muito na solução de novos problemas que surgem no dia a dia. $\mathrm{Na}$ análise dos resultados do workshop pode-se observar que houve várias coincidências nas respostas dos GT para sugestões de melhorias na gestão de REEE do Campus QS/D da USP. Destacam-se a disponibilização de espaço físico para armazenamento temporário de REEE, a ação conjunta das unidades para compras e logística reversa e a reformulação do sistema MERCURIO ou a criação de outro sistema de informação.

Os resultados do workshop proporcionaram uma visão real da situação dos REEE institucionais na prática e das dificuldades encontradas, além de revelar diferentes pontos de vista dos diferentes setores do Campus QS/D da USP, sobre a mesma questão. Considera-se que essas reuniões podem constituir uma ferramenta útil para o monitoramento do sistema de gestão dos REEE na prática, como complemento às informações fornecidas pelo SIAP. Os comentários e sugestões resultantes foram fundamentais para a formulação das diretrizes para um plano de gestão integrada de REEE na instituição, conforme o resumido a seguir: 
$\checkmark$ Criar um sistema de informação gerencial com informações específicas para os REEE, que possa ser integrado ao Sistema de Informação da Administracao Patrimonial (MERCURIO). Padronizar procedimentos e capacitar os operadores do sistema.

$\checkmark$ Criar um registro para EEE não patrimoniados, baterias, lâmpadas, peças e componentes.

$\checkmark$ Criar um protocolo de procedimentos de baixa e descarte dos REEE e promover a capacitação dos funcionários que trabalham com o Sistema MERCURIO.

$\checkmark$ Disponibilizar um espaço físico adequado e especifico para o armazenamento temporário de REEE em todas as unidades. Capacitação dos operadores para segregação, teste de funcionamento, retirada de componentes perigosos, acondicionamento e manejo correto de REEE.

$\checkmark$ Padronizar o modelo de gestão de REEE em todas as áreas, com um sistema único de coleta seletiva para todas as unidades. Padronizar os procedimentos desde o inicio, a começar pelo requisitante e incluir armazenamento, descarte e destino dos REEE.

$\checkmark$ Promover o ganho de economia de escala na aquisição conjunta de bens e serviços

$\checkmark$ Realizar oficinas de capacitação para reutilização e desmontagem de REEE.

$\checkmark$ Promover a reutilizacao de REEE e campanhas educativas e de comunicação dirigidas a toda a comunidade universitária.

$\checkmark$ Promover reuniões e integração entre os setores envolvidos com a questão dos REEE nas unidades, para trocas de experiências sobre boas práticas de gestão, estudo e discussão sobre sugestões e ações propostas e sobre soluções para os novos problemas que surgirem.

$\checkmark$ Promover maior envolvimento do USP Recicla com a questão dos REEE.

$\checkmark$ Definir e adotar uma política única de REEE no QS/D para compra, patrimônio, uso, doação, descarte e armazenamento dos EEE e REEE.

$\checkmark$ Manter a periodicidade da coleta seletiva e definir procedimentos únicos para o descarte e para as operações de gerenciamento interno.

$\checkmark$ Criar mecanismos para a fácil localização e rastreabilidade dos EEE/REEE.

$\checkmark$ Disponibilizar coletores para: pilhas e baterias, lâmpadas, celulares, pequenos EEE e cartuchos, em locais estratégicos, em todas as unidades. 


\subsection{IDENTIFICAÇÃO DE POTENCIAIS IMPACTOS DO FLUXO DE REEE GERADOS NO CAMPUS QS/D DA USP}

Com base nas informações obtidas nas visitas realizadas às unidades do QS/D e aos locais de destino dos REEE, identificou-se uma série de impactos negativos na saúde, no ambiente, na economia e na sociedade.

\subsubsection{Impactos dos REEE na saúde do trabalhador}

Os impactos na saúde ocupacional se iniciam já dentro da instituição, com os procedimentos sem critérios de armazenamento e descarte dos REEE. Observou-se que, em função da ausência generalizada do uso de EPIs, os funcionários envolvidos com o manejo desses resíduos são expostos às substâncias perigosas que podem ser liberadas dos equipamentos, caso esses se rompam. A precariedade, a falta de segurança e de cuidado ano armazenamento e no transporte dos REEE facilita o rompimento dos equipamentos, com riscos à saúde do trabalhador, tornando o ambiente propício a reações químicas, sinergismos e potencializações de efeitos tóxicos, incêndios e acidentes de trabalho. Em situações adversas, esses fatores constituem condições ideais para a contaminação do ambiente e para riscos de acidentes.

O fluxo segue causando impactos negativos, tanto na saúde do trabalhador quanto no ambiente em todas as etapas do processo. O que se chama de "reciclagem" é, na realidade, uma atividade de desmontagem dos equipamentos, para retirar os componentes interessantes do ponto de vista econômico e descartar de maneira irresponsável o que consideram rejeito ou refugo. Com raras exceções o resíduo é tratado e destinado de maneira adequada em todas as etapas, até a disposição final.

As atividades típicas desenvolvidas para recuperação e reciclagem de REEE (RECILEC, 2010) são: recebimento, teste para verificação do funcionamento, conserto, desmontagem manual e mecânica, trituração, moagem, queima e fusão. As principais preocupações sob o ponto de vista da saúde do trabalhador estão relacionadas à exposição durante os processos de reciclagem mecânica ou térmica: trituração, moagem, queima e fusão, onde ocorre liberação de substâncias tóxicas (ENVIRONMENT CANADA, 2001). Nas unidades visitadas ocorrem apenas as etapas de recebimento, teste, conserto e 
desmontagem manual, etapas que também podem oferecer alguns riscos, como pode ser observado no Quadro 7.

Quadro 7 - Resumo das atividades nas plantas de reciclagem visitadas

e seus potenciais impactos na saúde do trabalhador

\begin{tabular}{|l|l|}
\hline \multicolumn{1}{|c|}{ ATIVIDADE } & \multicolumn{1}{|c|}{ SAUDE DO TRABALHADOR } \\
\hline Recebimento & $\begin{array}{l}\text { Cortes e perfurações devido a exposição a objetos perfurocortantes, ou } \\
\text { inalação de poeira de vidro quebrado de monitores e tubos fluorescentes. }\end{array}$ \\
\hline Teste e conserto & Choque elétrico no contato com fontes e cabos elétricos. \\
\hline $\begin{array}{l}\text { Desmontagem } \\
\text { manual }\end{array}$ & $\begin{array}{l}\text { Inalação de poeiras liberadas durante o processo. Problemas } \\
\text { ergonômicos, por movimentos repetitivos, exposição a substâncias } \\
\text { tóxicas por contato. }\end{array}$ \\
\hline Armazenamento & $\begin{array}{l}\text { Os equipamentos podem se romper e liberar substâncias tóxicas ou } \\
\text { provocar ferimentos nas pessoas que os manejam. }\end{array}$ \\
\hline
\end{tabular}

A adoção de medidas de segurança, como a manipulação controlada dos REEE, o uso de EPIs, um ambiente com iluminação e ventilação adequadas, o mobiliário apropriado, uso de ferramentas corretas para a operação, pode minimizar os riscos ocupacionais e a exposição a substâncias perigosas. A capacitação e a informação são fundamentais, em todas as etapas do gerenciamento, o que nem sempre ocorre, conforme foi observado durante as visitas.

\subsubsection{Impactos dos REEE no ambiente}

A questão da liberação de substâncias perigosas, provenientes de REEE no ambiente é tema pouco pesquisado. De acordo com MJ \& Associais (2004) existem três caminhos potenciais, pelos quais as substâncias perigosas podem entrar em contato com o meio ambiente. Um deles seria por dispersão de poeiras resultantes do processo de trituração nas instalações de reciclagens sendo essas depositadas no solo, em áreas úmidas dentro e fora da planta de instalação e ingerida ou absorvida por alguma espécie importante para sobrevivência do ecossistema local. Outra via seria através do uso da água em qualquer etapa do processo, principalmente se a poeira não for controlada, podendo causar a deposição de substâncias perigosas no solo e na água. Outra via de contaminação seria por armazenamento dos REEE em espaço aberto antes de ser desmontados. Com a ação das intempéries, como a chuva, a umidade, a exposição ao sol e calor, pode ocorrer a lixiviação de substâncias que serão depositadas no solo ou água. 
Em relação aos locais visitados, o primeiro dos caminhos de contaminação ambiental descritos dificilmente ocorreria, pois a trituração não é uma etapa presente nas instituições visitadas. Já os outros dois caminhos são possíveis, principalmente o terceiro, pois em um dos locais, muitos REEE ficavam armazenados a céu aberto e em contato direto com o solo. Além disso, a desmontagem dos equipamentos é seguida da segregação de componentes com e sem valor comercial. Nas instituições filantrópicas, os equipamentos sem condições de recuperação e sem valor comercial são repassados a sucateiros em lotes. Geralmente, esses materiais são os que contêm maior quantidade de substâncias perigosas, como pilhas, baterias e tubos de imagem. Esses, em algum momento acabam sendo descartado junto aos resíduos comuns, dada à inexistência de coleta seletiva específica, o que na melhor das hipóteses acabam em aterros para resíduos; quando não, estão sendo lançados diretamente no ambiente, sem controle e de forma irresponsável.

\subsubsection{Impactos sociais e econômicos dos REEE}

Pode-se também constatar a ocorrência de impactos sociais e econômicos, em função da falta de informação, capacitação e fiscalização na gestão interna e externa dos REEE institucionais.

No âmbito social, os impactos são provocados principalmente por operações não regulamentadas, sem controle, ou mesmo clandestinas de gerenciamento desses resíduos que, além dos impactos ambientais e na saúde já mencionados, deixam de gerar emprego e renda. Observou-se, em alguns casos, a total falta de conhecimento de alguns operadores sobre suas funções e sobre os riscos envolvidos. Chama à atenção a contratação temporária de trabalhadores, em programas sociais de combate ao desemprego, por um salário simbólico, sem nenhum direito trabalhista e sem nenhum pré-requisito conhecimento ou de instrução, para separar desmontar e reciclar o material doado. As condições precárias de trabalho observadas, com exposição direta a substâncias perigosas, sem o uso de equipamentos de segurança individual (EPI) e sem conhecimento dos riscos envolvidos, comprometem a saúde e a vida do trabalhador e de sua família, causando danos muitas vezes irreversíveis. A capacitação profissional e melhores condições ambientais, sociais, de saúde e de segurança de trabalho são fundamentais para a formação de mão de obra qualificada, em todas as etapas operacionais do fluxo de REEE, resultando mais oportunidades de trabalho, com melhor qualidade de vida e renda mais justa. 
Os impactos econômicos negativos decorrem das atividades clandestinas ou ilegais que deixam de arrecadar impostos, da grande quantidade de REEE que deixa de ser reciclada e dos componentes valiosos que são exportados para reciclagem em outros países, por falta de incentivos e de pesquisas para desenvolvimento de processos de reciclagem no Brasil. Constata-se que a prática da doação pode causar impactos negativos econômicos, sociais, ambientais e de saúde pública.

A sustentabilidade da gestão dos REEE na instituição requer o desenvolvimento de uma cultura que contemple todos os seus aspectos fundamentais, além das questões administrativas internas e do cumprimento das exigências legais. Deve-se ter uma clara noção clara do que já existe e do que é possível obter a partir de uma nova mentalidade a ser introduzida, direcionando todas as culturas e subculturas à mudança de comportamento e à evolução institucional, visando à construção de um sistema de gestão integrada de REEE. O foco da responsabilidade social institucional deve ser pautado na promoção da atuação ética. Além de promover a melhoria de seus recursos internos, é preciso ter uma visão da importância de seu papel na promoção da qualidade de vida da comunidade que a cerca. 


\subsubsection{Deficiências na gestão de REEE identificadas no Campus QS/D da USP}

Identificaram-se falhas em todas as etapas da gestão dos REEE nas unidades visitadas da USP. As principais deficiências estão resumidas no Quadro 8:

Quadro 8: Deficiências na gestão de REEE identificadas no Campus QS/D da USP

\begin{tabular}{|c|c|c|c|}
\hline ETAPA & RESPONSÁVEL & DEFICIÉNCIA & POSSÍVEL SOLUÇÃO \\
\hline $\begin{array}{l}\text { Aquisição de } \\
\text { REEE }\end{array}$ & $\begin{array}{ll}\text { - } & \text { Usuário } \\
\text { - } & \text { Diretoria } \\
\text { - } & \text { Setor de Compras }\end{array}$ & $\begin{array}{ll}\text { - } & \text { Consumo consciente } \\
\text { - } & \text { Controle } \\
\text { - } & \text { Planejamento }\end{array}$ & $\begin{array}{ll}\text { - } & \text { Planejamento } \\
\text { - } & \text { Mudança de } \\
& \text { Comportamento } \\
\text { - } & \text { Negociação }\end{array}$ \\
\hline $\begin{array}{l}\text { Vida útil de } \\
\text { REEE }\end{array}$ & 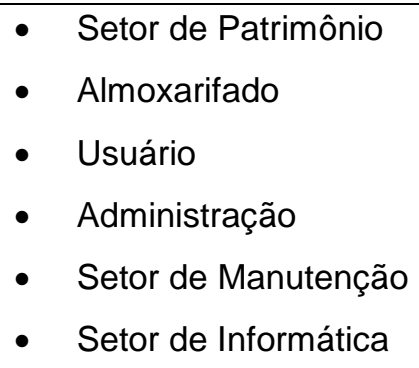 & $\begin{array}{ll} & \text { Sistema de Informação } \\
\text { - } & \text { Controle } \\
\text { - } & \text { Cuidados com os EEE } \\
\text { - } & \text { Informação e } \\
& \text { Comunicação } \\
\text { - } & \text { Descarte } \\
\text { - } & \text { Desperdício }\end{array}$ & $\begin{array}{ll}\text { - } & \text { Reformulação do Sistema } \\
& \text { de Informação } \\
\text { - } & \text { Mudança de comportamento } \\
\text { - } & \text { Mudança de infraestrutura } \\
\text { - } & \text { Campanhas de Informação } \\
\text { - } & \text { e conscientização } \\
\text { - Integração dos Setores }\end{array}$ \\
\hline $\begin{array}{l}\text { Gerenciamento } \\
\text { interno de } \\
\text { REEE }\end{array}$ & $\begin{array}{ll}\text { - } & \text { Administração } \\
\text { - } & \text { Infraestrutura } \\
\text { - } & \text { Setor de Segurança, } \\
& \text { Saúde e Meio } \\
& \text { Ambiente } \\
\text { - } & \text { Setor de Patrimônio } \\
\text { - } & \text { USP Recicla } \\
\text { - Zeladoria }\end{array}$ & $\begin{array}{ll}\text { - } & \text { Controle } \\
\text { - } & \text { Capacitação } \\
& \text { operacional } \\
\text { - } & \text { Informação e } \\
& \text { Comunicação } \\
\text { - } & \text { Logística reversa } \\
\text { - } & \text { Coleta Seletiva } \\
\text { - } & \text { Armazenamento } \\
& \text { temporário } \\
\text { - } & \text { Manejo dos REEE } \\
\text { - } & \text { Condições de } \\
& \text { segurança, saúde do } \\
& \text { trabalhador e meio } \\
& \text { ambiente } \\
\text { - } & \text { Falta de integração } \\
\text { entre os setores }\end{array}$ & $\begin{array}{ll}\text { - } & \text { Mudança de infraestrutura } \\
\text { - } & \text { Capacitação operacional } \\
\text { - } & \text { Mudança comportamental } \\
\text { - } & \text { Segregação } \\
\text { - } & \text { Retirada de componentes } \\
& \text { perigosos } \\
\text { - } \quad \text { Controle da quantidade de } \\
\text { - } \quad \text { REEE gerado } \\
\text { - } \quad \text { Controle de Destinação } \\
\text { - } \quad \text { interno do gerenciamento } \\
\text { - } \quad \text { pantrole dos REEE nãoniados } \\
\text { Padronização de } \\
\text { procedimentos }\end{array}$ \\
\hline $\begin{array}{l}\text { Gestão externa } \\
\text { de REEE }\end{array}$ & $\begin{array}{ll}\text { - } & \text { Instituição geradora } \\
\text { - } & \text { Gestão Ambiental }\end{array}$ & $\begin{array}{l}\text { - Não há seguimento do } \\
\text { fluxo de REEE } \\
\text { - Não há rastreabilidade }\end{array}$ & $\begin{array}{ll}- & \text { Monitoramento do fluxo } \\
\text { - } & \text { Identificação dos REEE } \\
\text { - } & \text { Garantia de destino } \\
& \text { adequado } \\
\end{array}$ \\
\hline
\end{tabular}




\subsection{PESQUISA DE CAMPO NA UNIVERSIDADE DE CÁDIZ}

A pesquisa de campo na UCA iniciou-se com levantamento de dados censitários de todos os bens registrados em seu sistema de informação da Administração de Patrimônio SICOC, para estimar a geração e caracterizar os REEE gerados na instituição, no período compreendido entre o segundo semestre de 2000 e o primeiro semestre de 2010. Esse material inclui as dez categorias da Diretiva WEEE 2002/96/CE e de sua revisão (UE, 2008), que integra as Diretivas WEEE (2002/96/CE), RoHS (2002/95/CE) e 2006/66/CE (pilhas e acumuladores), considerados nesta pesquisa.

Analogamente ao que ocorre no SIAP - MERCURIO da USP, o SICOC da UCA não contem registros dos dados de data dos bens, peso e destino dos bens baixados. A diferença encontrada foi que, após os procedimentos de baixa, o gerenciamento interno dos REEE da UCA é de responsabilidade do Setor de Prevenção, que faz a destinação de acordo o que é determinado na legislação, para a gestão externa. Para conhecer o destino dos REEE após deixar a instituição, realizou-se pesquisa documental junto ao Setor de Prevenção, o qual forneceu também informações sobre o funcionamento do sistema de gerenciamento interno e destinação desses resíduos. Os REEE baixados do patrimônio da UCA são encaminhados para um gestor externo, que faz a logística reversa do material retirado.

A base de dados global do Sistema de Informação Gerencial é complexa e contem muitas informações sem interesse para esta pesquisa. Dos registros do sistema, foram selecionados apenas os dados referentes à origem dos bens, sua descrição e data de baixa, para criar nova base de dados. Com a mesma metodologia empregada na USP, a análise quantitativa foi utilizada para: a) caracterizar os tipos de REEE institucionais; b) conhecer a frequência dos REEE por categorias, nas IES investigadas; c) conhecer a evolução anual da geração de REEE em cada IES investigada; d) estimar o volume em peso/ ano dos REEE gerados na instituição. Os dados obtidos indicaram a necessidade de informações complementares para a elaboração do diagnóstico. Na comparação entre os resultados da pesquisa documental nas duas IES, observa-se que a existência de legislação específica sobre a gestão REEE exerce influência sobre a gestão desses resíduos na instituição e, gera impacto ambiental positivo, ao impor um sistema integrado de gestão para esses resíduos. 


\subsubsection{Geração e caracterização de REEE na UCA}

O levantamento de dados no SICOC abrangeu 9903 itens e inclui todos os bens patrimoniais baixados entre 2000 e 2010. Desses, foram consideradas 7877 unidades referentes às categorias REEE e os outros foram classificados como não considerados (NC). Analisou-se a evolução das variáveis consideradas durante o período de dez anos. Observouse que os dois sistemas de informação apresentam características similares entre si e contêm praticamente as mesmas informações, o que torna os resultados mais facilmente comparáveis.

\subsubsection{Evolução da geração de REEE na UCA por ano}

A análise estatística dos dados indica que a evolução da geração anual de REEE na UCA, desde o início dos registros de baixas no SIOC (2000 - 2010), não corresponde a um crescimento linear, conforme mostra o Gráfico 8.

Gráfico 8: Participação percentual de REEE baixados da UCA por ano (\%) $(2000-2010)$

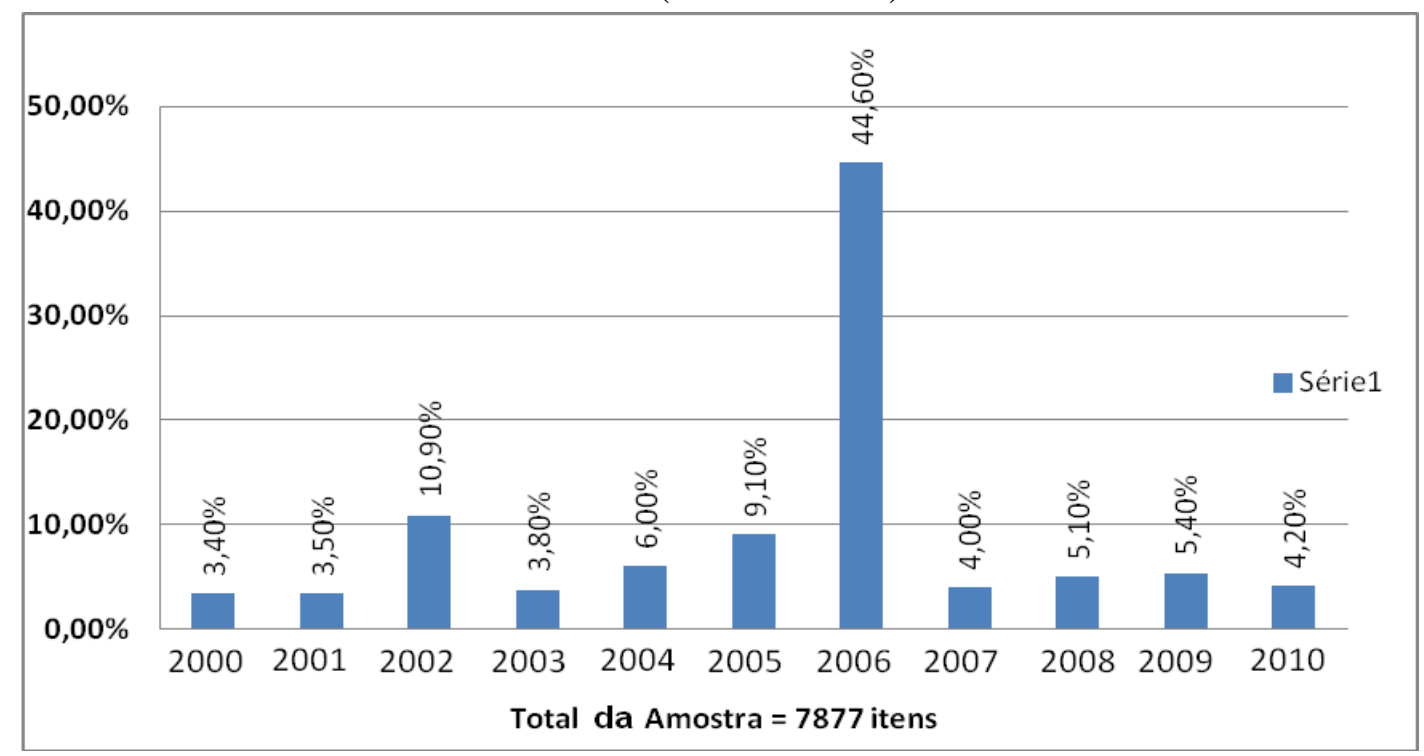

Neste caso, os resultados apontam para uma forte influência da mudança de legislação. Os registros da Administração de bens patrimoniais no SICOC tiveram inicio no ano 2000. A transposição das Diretivas da WEEE e RoHS (CE, 2002) para a legislação nacional espanhola, por meio do Real Decreto 208/2005, com vigência a partir de 2006, resultou no descarte de grande parte dos REEE acumulados na instituição, à espera das novas determinações legais. 
No Gráfico 9 pode-se comparar a evolução da geração de REEE nas duas IES estudadas e observar que em nenhum dos dois casos a evolução é linear. Além do fator legal, este resultado pode depender também do fator econômico, incluindo verbas para aquisição/substituição de tecnologia, início ou fim de projetos específicos, criação de novas unidades, reformas, mudanças de instalações e outros.

Gráfico 9: Comparativo entre a evolução da geração anual de REEE na UCA e na USP

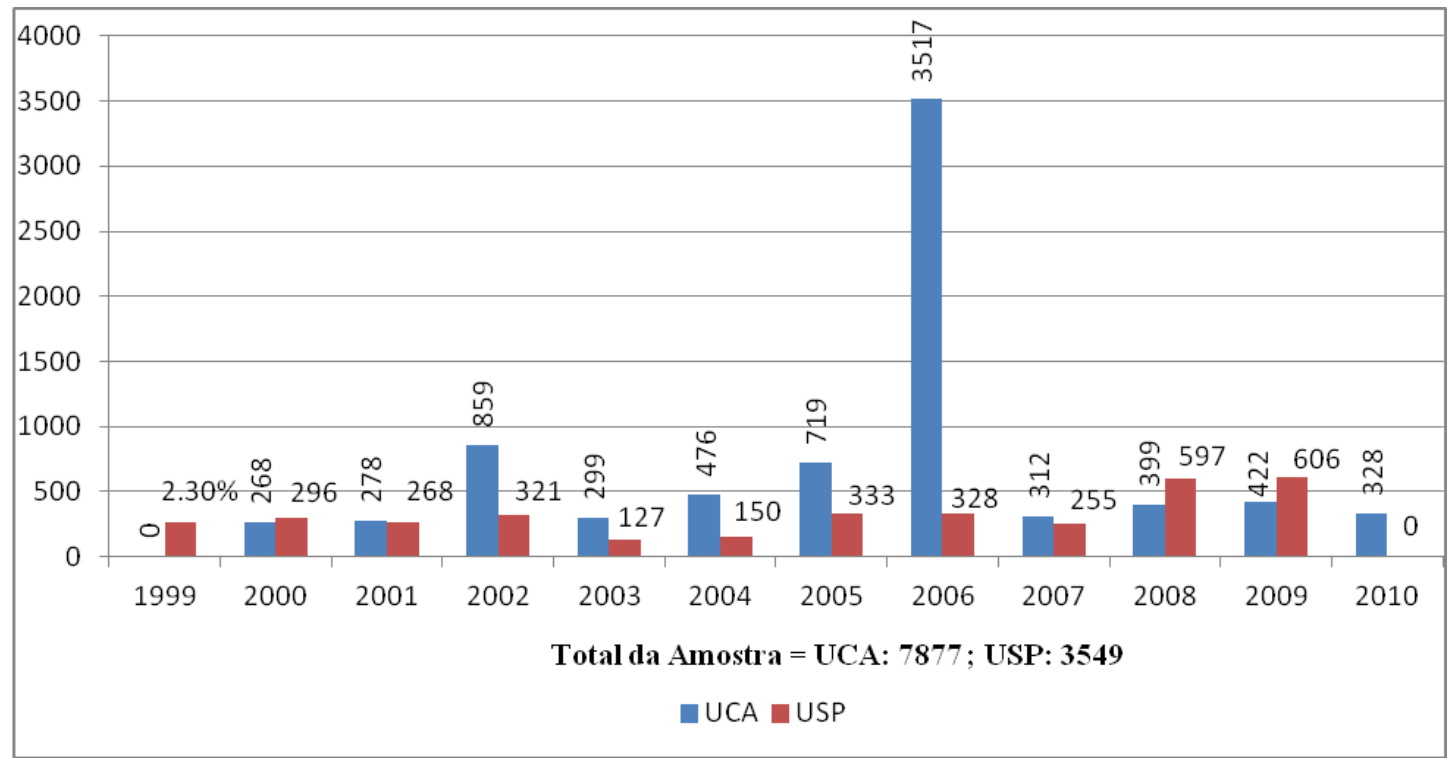

\subsubsection{Distribuição da geração de REEE da UCA por tipo de material}

A alimentação de dados de descrição dos bens no SICOC é realizada por diferentes pessoas e não obedece a nenhum critério de padronização. Cada um faz o registro de uma maneira diferente, o que dificulta muito a análise estatística. Para reduzir o número de variáveis, tentou-se agrupar os itens por tipos. Os acessórios e componentes de informática aparecem com uma participação pequena em relação aos equipamentos de informática, o que pode ocorrer em função da não obrigatoriedade de incorporação desse material ao patrimônio da instituição. O mesmo vale para equipamentos de iluminação e baterias. A pequena participação percentual dos equipamentos médicos pode ser explicada pela existência de outro sistema de administração de bens patrimoniais para esse tipo de equipamento, no Campus de Ciências da Saúde. O restante consiste de uma grande diversidade de REEE que foram agrupados de acordo com as categorias da UE ou, em função de frequência e sua periculosidade. Conforme mostra o Gráfico 10, se considerarmos somente as impressoras 
(incluindo fotocopiadoras), esses representam aproximadamente de $18 \%$ dos REEE descartados na UCA que poderiam ter sido classificados como não perigosos.

Gráfico 10 - Distribuição percentual de REEE baixados da UCA por tipo de material (grupos) $(2000-2010)$

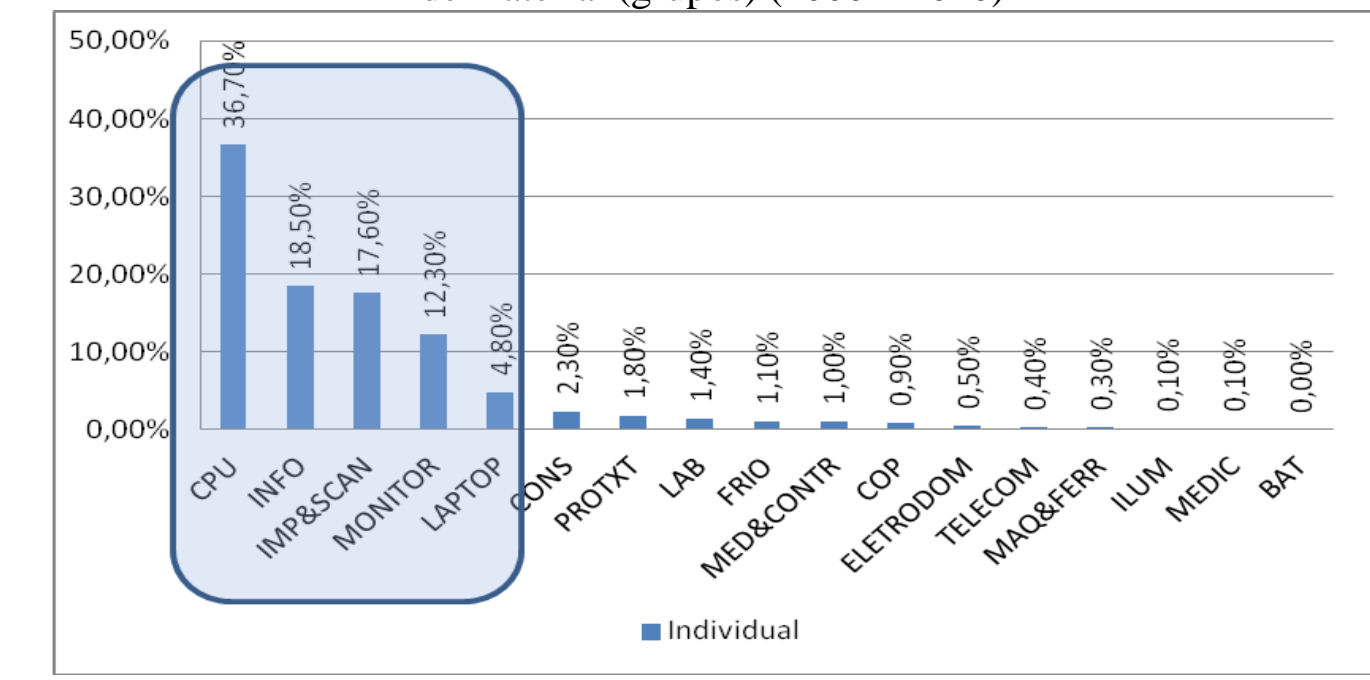

*Total da Amostra = 7877 itens.

IMP\&SCAN (Impressoras \& Scanners) inclui fotocopiadoras.

$\angle A B=$ Equipamentos de Laboratório.

PROTEXT = Processadores de texto, máquinas de escrever.

MED\&CONTR = Equipamentos de Medição e Controle.

$B A T=$ Baterias.

INFO=Acessórios de Informática.

$M E D I C=$ Equipam. Médicos.

MAQ\&FERR= Máquinas e Ferramentas.

$V E I C=$ Veículos

$\mathrm{CO}=$ Copiadoras.

ILUM = Equipam. de iluminação.

$N C=$ Não considerados

A pequena participação de equipamentos portáteis de TIC no total de EEE baixados do patrimônio, não significa que esses sejam pouco ferquentes e, se justifica por se tratar de bens de consumo, não patrimoniáveis. O aumento na geração de REEE é diretamente proporcional ao surgimento de novas tecnologias, causando a obsolescência e extinção de outras. A tendência indicada por ZICKUHR (2011), de que cada vez mais, as novas gerações tem dado preferência por equipamentos de TIC portáteis, pode ser preocupante, em termos de gestão de REEE em IES. Essas instituições são basicamente dirigidas à formação de novas gerações de educadores, cientistas, tecnólogos, pesquisadores e outos profissionais que decidirão os caminhos do futuro. É preciso que esses jovens, ávidos por novidades em tecnologia, sejam orientados ao consumo responsável e destinação correta de seus EEE, com prioridade para a reutilização. 


\subsubsection{Classificação dos REEE baixados da UCA segundo a periculosidade}

$\mathrm{Na}$ Espanha, os recicladores de REEE classificam como resíduos perigosos aqueles que possuem em seu conteúdo algum componente perigoso no momento do descarte. Assim, a quantidade de REEE perigosos gerados em uma instituição vai depender diretamente da maneira como se faz o gerenciamento interno desses resíduos, antes de encaminhá-los para a gestão externa. Se houver a etapa de segregação, com o procedimento de retirada de alguns componentes básicos como cartuchos, lâmpadas ou baterias, o volume de REEE perigosos diminuirá consideravelmente. Esse procedimento simples poderia diminuir sensivelmente os custos operacionais em todas as etapas da gestão integrada da gestão. Neste caso, por não haver a prática de segregação na origem antes do descarte, foram considerados perigosos todos os REEE que possuíam componentes perigosos de acordo com os critérios da Lista Europeia de Residuos - LER (pag. 32), no momento da baixa. A maioria dos REEE foi classificada como resíduo perigoso, conforme o Gráfico 11.

\section{Gráfico 11 - Participação percentual de REEE baixados da UCA por periculosidade $(2000-2010)$}

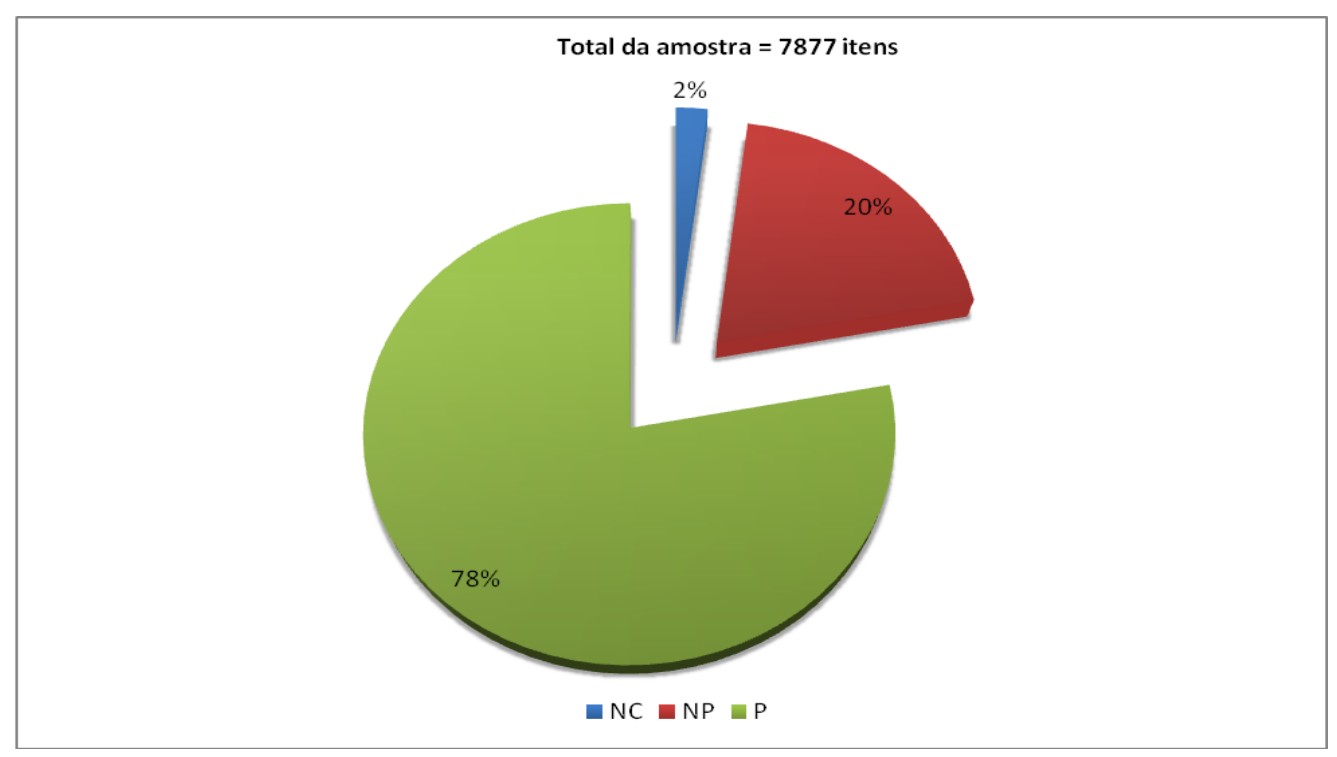

Segundo informações obtidas junto a gestores externos de REEE, a etapa de segregação dos REEE na origem gera impacto econômico positivo no sistema de gestão integrada desses resíduos. Quanto menor o volume de material perigoso a ser enviado para descontaminação, menor será o custo operacional do tratamento, cobrado por peso. Quanto maior o volume de recicláveis, menores são os custos operacionais. Dependendo do grau de segregação na origem, esses materiais podem ser retirados sem custos ou mesmo comprados 
por alguns gestores finais. Em qualquer caso, a coleta e destinação final de resíduos não perigosos tem sempre um custo menor que a de perigosos, mesmo quando esses não possuem valor agregados ou não são interessantes do ponto de vista de reciclagem.

Entre os resíduos perigosos, foram consideradas as impressoras, uma vez que se constatou a inexistência do procedimento de retirada de cartuchos ou de toners (componentes perigosos) antes de seu descarte, do mesmo modo como ocorre na USP. Ao se comparar os resultados encontrados nos levantamentos realizados na UCA e USP, constata-se que esses seguem a mesma tendência, quando se trata de analisar a variável periculosidade, conforme se pode observar na Tabela 10. Em ambos os casos, essa proporção poderia ser muito menor, se fosse adotado o procedimento de segregação na origem, para a retirada dos componentes perigosos, antes do descarte ou da destinação final.

Tabela 10 - comparativa da participação percentual de periculosidade dos REEE baixados na UCA e no Campus QSD/USP em um periodo de dez anos

\begin{tabular}{ccc}
\hline Bens baixados & QSD/USP & UCA \\
\hline NC & $0,10 \%$ & $2,0 \%$ \\
\hline NP & $13,10 \%$ & $20,0 \%$ \\
\hline $\mathbf{P}$ & $86,80 \%$ & $78,1 \%$ \\
\hline TOTAL & $\mathbf{1 0 0 , 0} \%$ & $\mathbf{1 0 0 , 0} \%$ \\
\hline
\end{tabular}

1. $P=$ REEE Perigosos

2. $N P=R E E E$ não Perigosos

3. $N C=$ Não considerados

\subsubsection{Classificação dos REEE baixados da UCA por categorias WEEE}

A classificação dos REEE (WEEE) da UE contempla os REEE do ponto de vista dos produtores. Analogamente aos resultados obtidos no levantamento realizado na USP, a análise dos dados indica que a grande maioria dos REEE baixados do patrimônio da UCA entre 2000 e 2010 pertence à categoria 3 (WEEE), correspondente aos equipamentos de informática e de telecomunicações (TIC) e que, guardadas as proporções, as outras categorias tendem a seguir a mesma ordem na participação percentual em relação ao total de REEE considerados nos dois casos, conforme se pode observar no Quadro 9. 
Quadro 9: Comparativo dos REEE baixados no Campus QS/D da USP e na UCA, em \% por categoria WEEE, em um período de 10 anos

\begin{tabular}{|l|r|r|}
\hline \multicolumn{1}{|c|}{ CATEGORIA WEEE } & \% USP & \% UCA \\
\hline NC & 0,7 & 1,9 \\
\hline $\mathbf{1}$ Grandes Eletrodomésticos & 10,1 & 1,7 \\
\hline $\mathbf{2}$ Pequenos Eletrodomésticos & 0,7 & 0,1 \\
\hline $\mathbf{3}$ EEE de TIC & 77,8 & 92,7 \\
\hline $\mathbf{4}$ EEE de Consumo & 3,1 & 1,4 \\
\hline $\mathbf{5}$ EEE de lluminação & 0,3 & 0,1 \\
\hline $\mathbf{6}$ Ferramentas EE & 0,4 & 0,3 \\
\hline $\mathbf{7}$ Brinquedos e EEE de Esporte e Laser & 0,0 & 0,0 \\
\hline $\mathbf{8}$ EEE Médicos & 1,2 & 0,4 \\
\hline $\mathbf{9}$ Instrumentos de Medição & 6,4 & 1,4 \\
\hline $\mathbf{1 0}$ Máquinas de venda Automática & 0,0 & 0,0 \\
\hline \multicolumn{1}{|c|}{ Total } & $\mathbf{1 0 0 , 0} \%$ & $\mathbf{1 0 0 , 0} \%$ \\
\hline
\end{tabular}

${ }^{*}$ Categorias WEEE da UE, conforme o descrito na legenda da Tabela 12.

No levantamento da UCA, a categoria 1, referente aos grandes eletrodomésticos participa com menos de $2 \%$ do total em unidades, mas representa uma fração importante, em temos de volume. Observa-se uma participação percentual muito pequena das categorias 2, 4 e 6, correspondentes respectivamente a pequenos equipamentos elétricos e eletrônicos, equipamentos destinados aos consumidores e a ferramentas elétricas, em relação ao seu uso em larga escala, curta durabilidade e substituição frequente na prática. Esses resultados podem não refletir a realidade e podem ser explicados por esses EEE não serem considerados como bens patrimoniais e sim como equipamentos de manutenção ou de consumo e, portanto, não entram no inventário do patrimônio. Os REEE pertencentes às categorias 7 e 10 não aparecem no inventário, possivelmente em função do tipo de instituição investigada. Os dados sobre os equipamentos médicos (categoria 8) e os instrumentos de medição e controle (categoria 9) muito frequentes em Universidades, podem também estar subestimados. Os NC (Não Considerados) correspondem aos resíduos que não estão incluídos em alguma categoria de REEE (como máquinas de grande porte, veículos, entre outros) e aqueles cujos registros não puderam ser decifrados. A participação percentual de cada categoria de REEE gerado na UCA, segundo a classificação da UE, está representada no gráfico 12. 
Gráfico 12 - Distribuição percentual de REEE baixados da UCA por categoria WEEE (UE) (2000 - 2010).

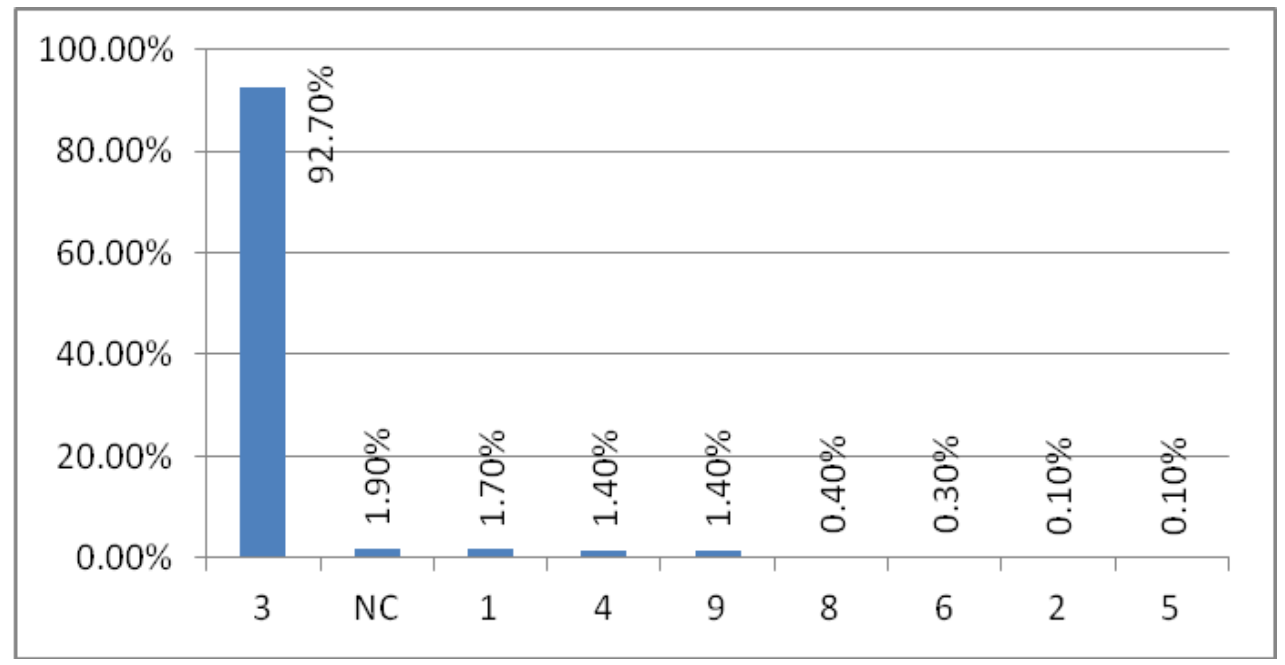

$N C=$ não considerados; $1=$ Grandes eletrodomésticos; $2=$ Pequenos eletrodomésticos; $3=$ EEE de TIC; 4 = EEE de consumo; $5=$ EEE de Iluminação; $6=$ Ferramentas EE; 7 = Brinquedos e EEE de Esporte e Laser; 8 = EEE Médicos; 9 = Instrumentos de Medição; 10 = Máquinas de venda automática.

O Gráfico 13 compara a distribuição de REEE por categoria WEEE da EU, nas duas IES estudadas, e confirma a predominância desse tipo de REEE nas IES. Em compensação, algumas categorias aparecem com frequência nula ou próxima de zero.

Gráfico 13 - Comparativo da distribuição percentual de REEE baixados do patrimônio da UCA e do Campus QS/D da USP por categoria WEEE (UE), no período de dez anos.

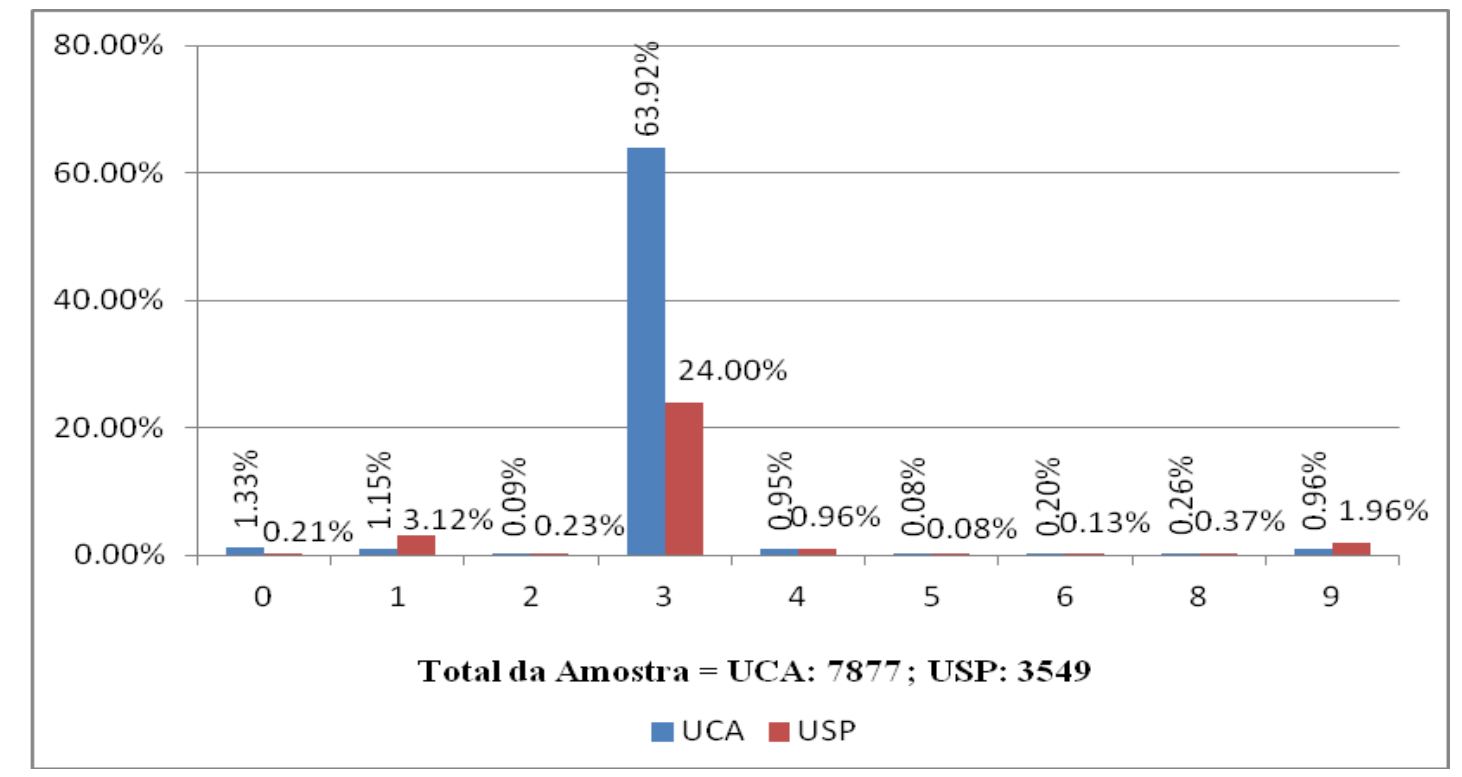




\subsubsection{Classificação dos REEE do ponto de vista de reciclagem}

Do ponto de vista de reciclagem, a classificação se orienta por aspectos práticos e econômicos da gestão, incluindo logística, tratamento e disposição final e classificam-se em cinco categorias operacionais, conforme o detalhado e justificado e no Quadro 4, apresentado anteriormente (subcapítulo 4.1.7.). A Tabela 11 indica a frequência em unidades de cada categoria de reciclagem, no total de itens baixados do patrimônio da UCA, entre 2000 e 2010.

Tabela 11 - Distribuição dos REEE baixados da UCA por categoria operacional $(2000-2010)$

\begin{tabular}{lr}
\hline \multicolumn{1}{c}{ CATEGORIA DE RECICLAGEM } & \multicolumn{2}{c}{$\begin{array}{l}\text { FREQUENCIA } \\
\text { (unidades) }\end{array}$} \\
\hline 1. NC (Não considerados) & 151 \\
\hline 1. Eletrodomésticos que contêm de refrigeração & 93 \\
\hline 2. Outros eletrodomésticos grandes e médios & 49 \\
\hline 3. Equipamentos de iluminação & 11 \\
\hline 4. EEE com monitores TRC e LCD & 2980 \\
\hline 5. Outros EEE & 4593 \\
\hline Total $^{*}$ & $\mathbf{7 8 7 7}$ \\
\hline
\end{tabular}

Estes resultados indicam que, do ponto de vista de reciclagem, consideram-se menos da metade dos REEE como perigosos e que, como tal, envolvem custos financeiros consideráveis em sua descontaminação. Isso, se não se incluem os equipamentos de iluminação que, apesar de representar grande maioria dos REEE de qualquer instituição, raramente aparecem em algum registro. Uma das grandes diferenças identificadas, na comparação entre as duas IES, é a gestão da categoria 3, que corresponde a resíduos de equipamentos de iluminação. Além de lâmpadas, os equipamentos de iluminação incluem luminárias. Na Espanha, a gestão de luminárias é efetuada por um SIG de REEE criado especialmente para esse fim, a Fundação ECOLUM. Os equipamentos de iluminação incluem:

- Luminárias para lâmpadas fluorescentes

- Lâmpadas fluorescentes retas (tubos)

- Lâmpadas fluorescentes compactas

- Lâmpadas de descarga de alta intensidade

- Lâmpadas de sódio de baixa pressão

- Outros equipamentos de iluminação utilizados para difundir o controlar luz, excluindo-se as lâmpadas de filamento (AMBILAMP, 2010). 
As Figuras 26 a 28 ilustram alguns exemplos de equipamentos de iluminação e lâmpadas incluídas na categoria 3 .

Figura 26 - Luminária para tubos fluorescentes retos

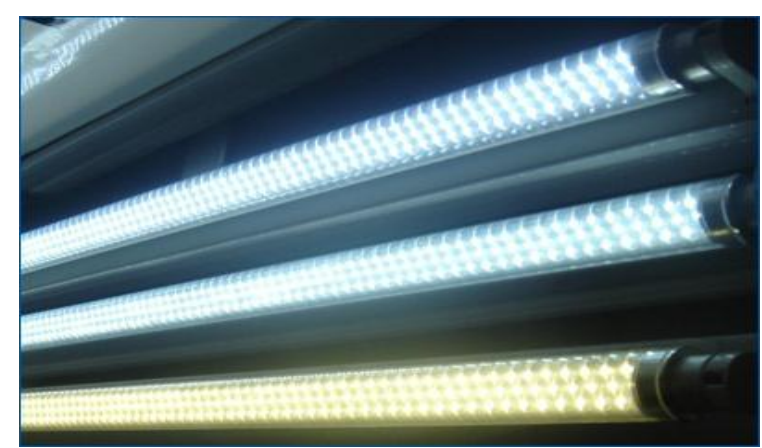

ECOLUM, 2010

Figura 27 - Luminária para exteriores

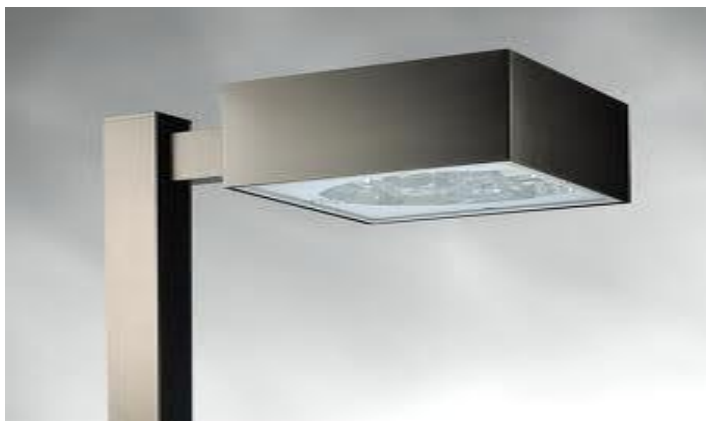

ECOLUM, 2010

Figura 28 - Detalhe de luminária para exteriores

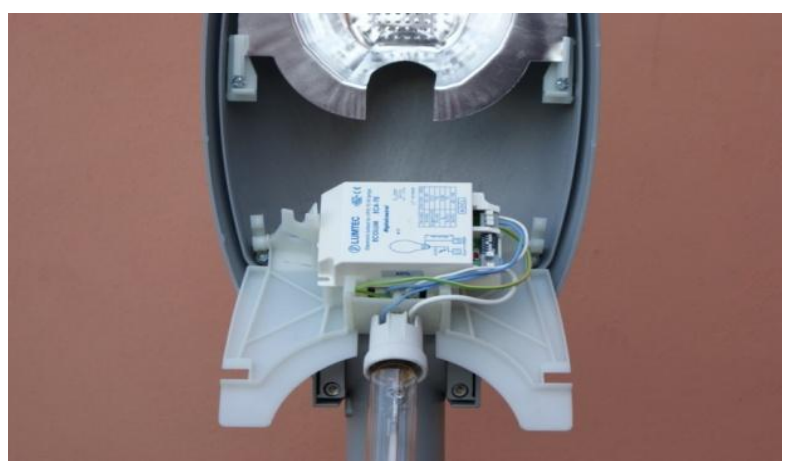

ECOLUM, 2010

Enquanto na USP as únicas lâmpadas enviadas para reciclagem são apenas os tubos fluorescentes, na Espanha, todos os REEE de equipamentos de iluminação, incluindo luminárias e todos os tipos de lâmpadas, com exceção das lâmpadas de filamento, devem ser 
enviados para reciclagem. As Figuras: 29 e 30 ilustram alguns tipos de luminárias e de lâmpadas que devem ser recicladas.

Figura 29 - Alguns tipos de equipamentos de iluminação

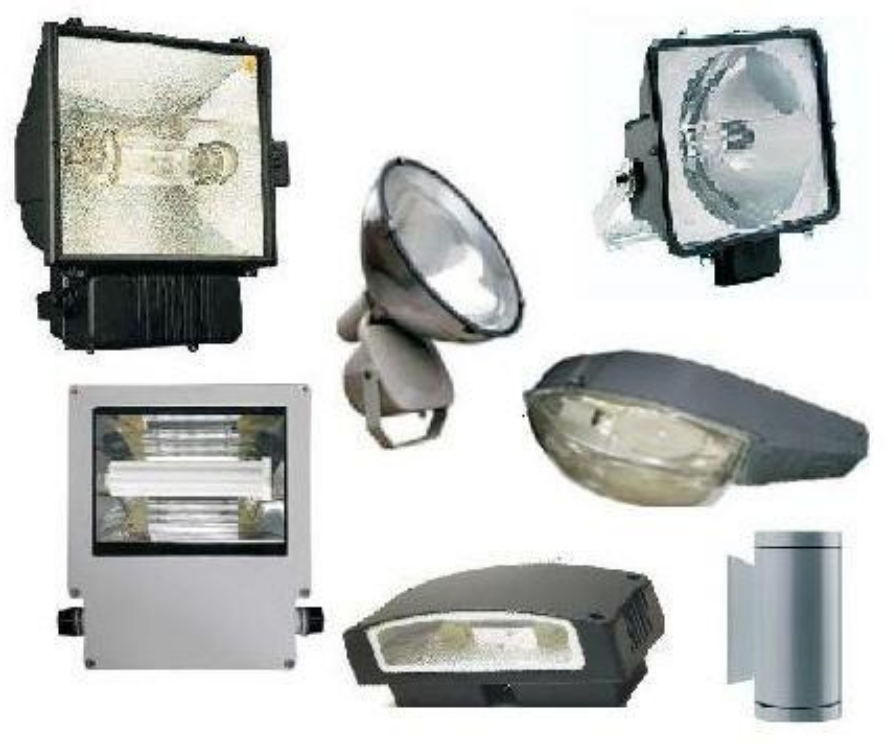

ECOLUM, 2011

Figura 30 - Alguns tipos de lâmpadas que devem ser recicladas

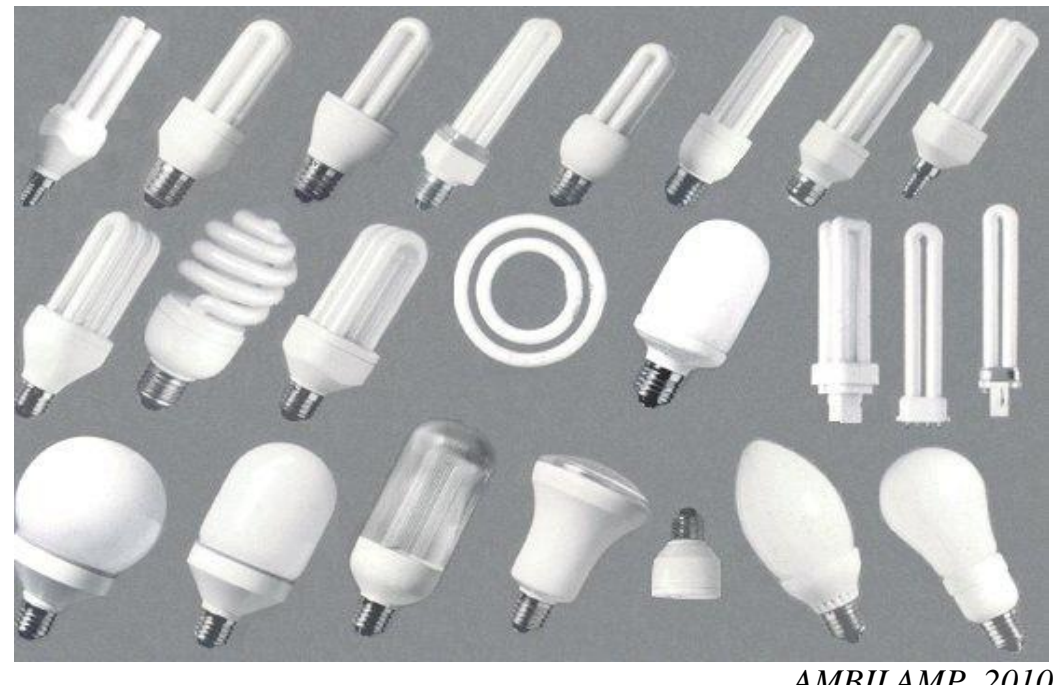

Entre os REEE descartados, chama à atenção a quase ausência da categoria 3, correspondente aos equipamentos de iluminação, embora sejam esses, sem dúvida, os de utilização e de substituição mais frequentes na prática. A análise dos dados segundo as categorias de reciclagem, também conhecidas por categorias operacionais, indica que, os resultados obtidos no levantamento realizado na UCA seguem a mesma tendência observada 
nos resultados do realizado na USP, com relação à grande participação percentual dos equipamentos com monitores TRC e LCD, no total de REEE descartados. Os Gráficos14 e 115 representam, respectivamente, a distribuição dos REEE por categoria de reciclagem, dos REEE baixados da UCA e, a comparação referente a essas categorias nas duas IES estudadas.

Gráfico 14: Participação percentual de REEE baixados da UCA por categoria de reciclagem $(\%)(2000-2010)$

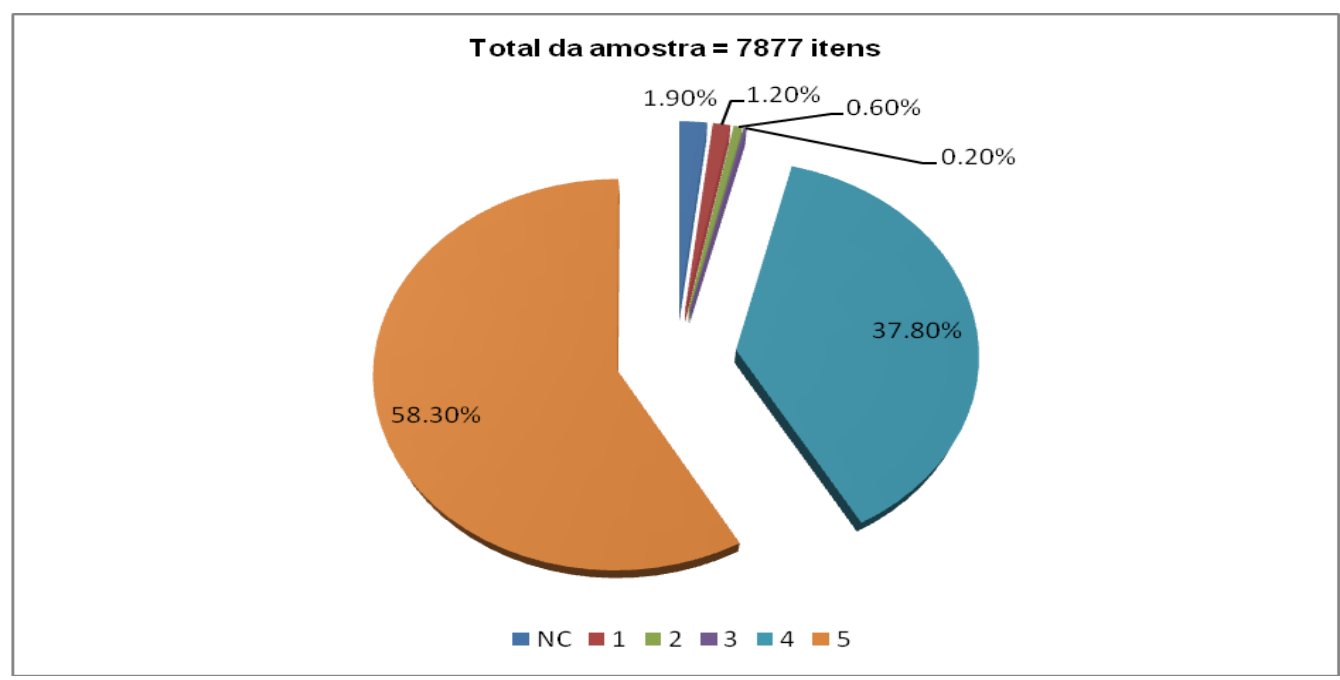

NC (Não considerados)

1. Eletrodomésticos que contêm de refrigeração

2. Outros eletrodomésticos grandes e médios

3. Equipamentos de iluminação

4. EEE com monitores TRC e LCD

5. Outros EEE

Gráfico 15: Comparativo entre a distribuição percentual de REEE baixados, por categoria de reciclagem na UCA e no Campus QS/D da USP, no período de dez anos

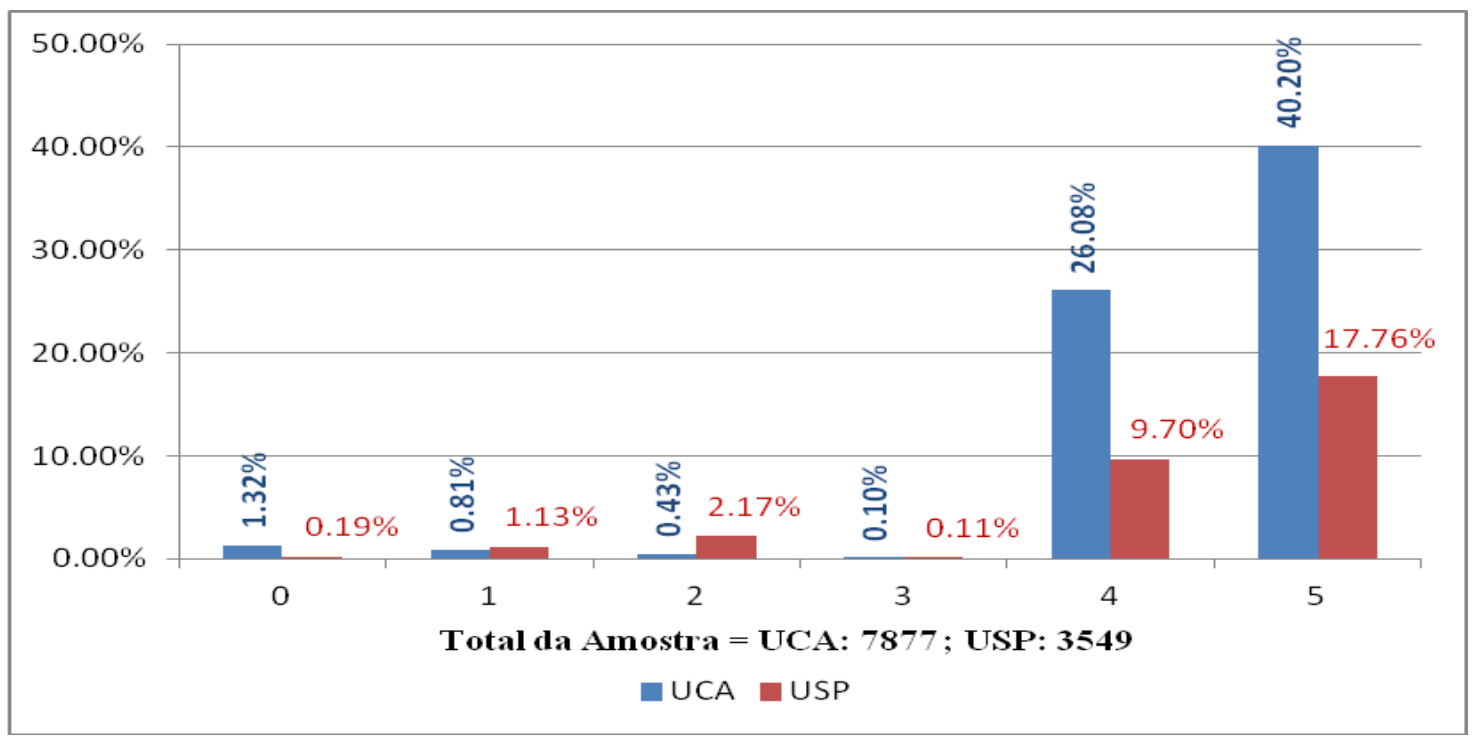




\subsubsection{Classificação dos REEE baixados da UCA por categoria de linhas de cor}

A classificação em categorias de cor em linha branca, linha marrom e linha cinza é, provavelmente, a mais conhecida do ponto de vista dos consumidores. No entanto, conforme já mencionado, à medida que novos produtos são desenvolvidos e, novos desenhos e cores vão surgindo, torna-se cada vez mais difícil sua classificação por categoria de cor. Neste caso, classificam-se como outros, os REEE que não se enquadram em nenhuma das três linhas. Do total de 7877 itens, não fora considerados 151 itens, em função da insuficiência de dados para caracterizá-los. A distribuição dos REEE por categoria de cor, baixados na UCA, no período investigado, está indicada na Tabela 12.

Tabela 12- Distribuição dos REEE baixados da UCA por categoria de cor (2000 - 2010)

\begin{tabular}{lc}
\hline COR & FREQUENCIA (unidades) \\
\hline BRANCA & 123 \\
\hline CINZA & 7314 \\
\hline MARROM & 108 \\
\hline NC & 151 \\
\hline OUTROS & 181 \\
\hline Total & $\mathbf{7 8 7 7}$ \\
\hline
\end{tabular}

$\mathrm{Na}$ classificação por linhas de cor e outros e não considerados (NC), observa-se novamente, entre os REEE baixados da UCA, no período de 2000 a 2010, a predominância dos REEE de TI, correspondentes à linha cinza, conforme o ilustrado no Gráfico 16.

Gráfico 16 - Participação percentual de REEE baixados da UCA por categoria cor $(\%)(2000-2010)$

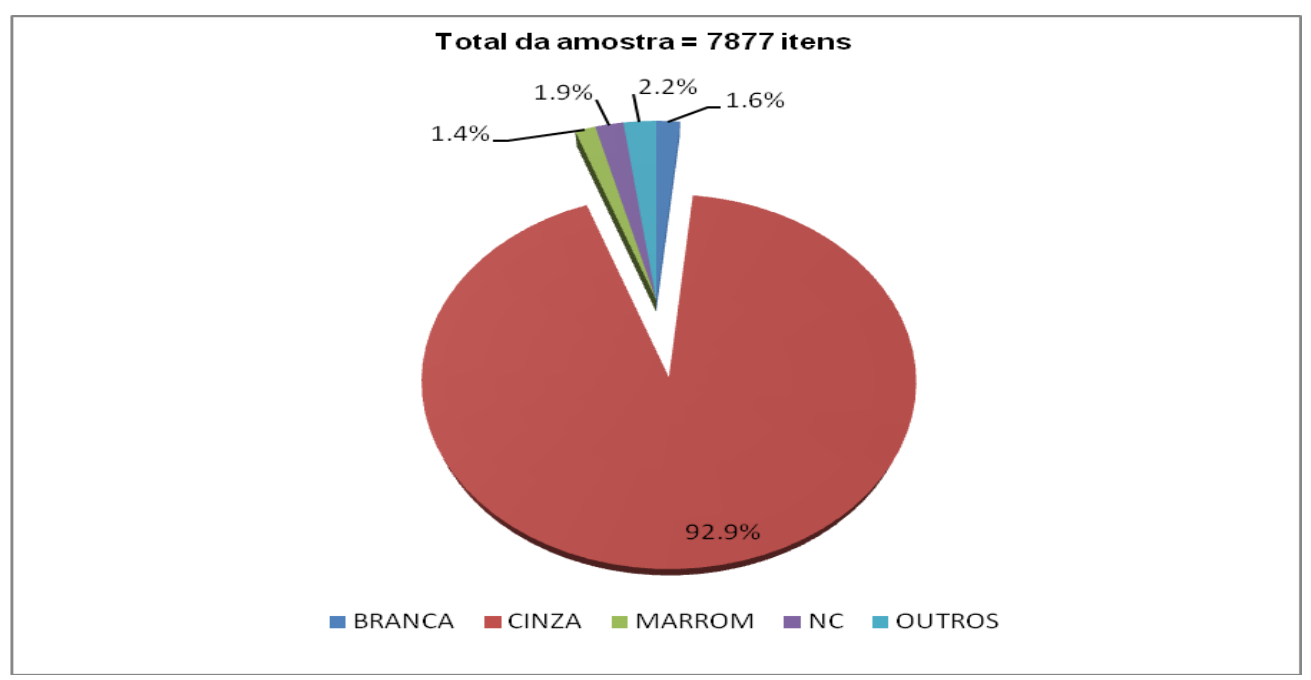




\subsubsection{Peso médio unitário e peso total}

A estimativa dos pesos médios unitários dos REEE gerados na UCA, feita item por item, foi uma das etapas mais complicadas desta pesquisa. Também neste caso, de maneira similar à que ocorre na USP, a falta de critério para os registros na alimentação do sistema dificulta e, às vezes, impossibilita o cálculo dessa variável, por falta de informação sobre alguns itens. Houve casos em que a descrição do equipamento se resumia em "aparelho de ótica", o que poderia significar tanto uma lupa como um microscópio eletrônico de grande porte. Por esse motivo, alguns dados foram considerados como não válidos.

A maioria (cerca de 90\%) dos pesos médios foi estimada com base nos dados disponíveis no website da Furniture Reuse Network (FRN, 2009). Contudo, para os restantes, foi necessário consultar a página do fabricante na internet, ou entrar em contato com o representante da marca na Espanha, o que algumas vezes apresentou certo grau de dificuldade, quando não se conhecia o modelo do equipamento. Nesses casos, obteve-se o peso médio experimentalmente, mediante a pesagem de três a cinco produtos similares e calculando-se a media. A distribuição dos pesos médios dos REEE baixados na UCA no período investigado está resumida na Tabela 13.

Tabela 13 - Estatística descritiva dos pesos médios anuais dos REEE gerados na UCA (2000 - 2010)

\begin{tabular}{lrr}
\hline ANO & PESO TOTAL (kg) & FREQUENCIA (unidades) \\
\hline $\mathbf{2 0 0 0}$ & 24384,0 & 268 \\
\hline $\mathbf{2 0 0 1}$ & 2333,8 & 278 \\
\hline $\mathbf{2 0 0 2}$ & 6497,5 & 859 \\
\hline $\mathbf{2 0 0 3}$ & 2160,1 & 299 \\
\hline $\mathbf{2 0 0 4}$ & 4780,0 & 476 \\
\hline $\mathbf{2 0 0 5}$ & 6104,3 & 719 \\
\hline $\mathbf{2 0 0 6}$ & 36012,2 & 3517 \\
\hline $\mathbf{2 0 0 7}$ & 3844,4 & 312 \\
\hline $\mathbf{2 0 0 8}$ & 3722,1 & 399 \\
\hline $\mathbf{2 0 0 9}$ & 3892,2 & 422 \\
\hline $\mathbf{2 0 1 0}$ & 3242,1 & 328 \\
\hline TOTAL & $\mathbf{7 4 5 7 7 , 0}$ & $\mathbf{7 8 7 7}$ \\
\hline
\end{tabular}


A análise dos dados indica que o ano em que mais se descartou REEE na UCA foi 2006, o que coincide com o ano em que se começou a gerenciar os REEE de forma separada dos outros resíduos, depois da transposição da Diretiva 2002/96/CE para a legislação espanhola, mediante o RD 208/2005.

Os resultados indicam que, a grande maioria dos REEE, consiste em equipamentos de TI. Em sua quase totalidade, a baixa é motivada por obsolescência ou por alguma avaria. Os laudos em geral atestam que o conserto não compensa do ponto de vista econômico. Com efeito, às vezes, por uma obsolescência programada, esses equipamentos já não têm capacidade para suportar as novas tecnologias que surgem em velocidade exponencial. Contudo, a recuperação desses REEE para reutilização em outras instituições, poderia trazer benefícios do ponto de vista econômico, social e ambiental.

Os resultados obtidos na estimativa de geração e caracterização de REEE, no sistema de informação da Administração Patrimonial, apontam para a predominância de equipamentos de TIC nas IES e indicam a baixa participação de equipamentos de iluminação e de portáteis, como equipamentos de manutenção. Na prática, muitos são os exemplos de REEE que não fazem são registrados. Entre esses, observa-se a predominância de equipamentos de iluminação sobre todos os outros, mas geralmente não constam dos registros. Nas grandes organizações, que possuem setor de manutenção próprio, as ferramentas elétricas e eletrônicas são itens básicos, mas sua participação no total de itens baixados do patrimônio é muito pequena. A tendência de crescimento de portáteis e de miniaturização de EEE faz com que esses sejam considerados como material de consumo e, portanto sem obrigatoriedade de registro. O procedimento de upgrade da capacidade dos equipamentos leva à substituição de partes e peças que não são consideradas REEE e, portanto, costumam ser descartadas com o resíduo comum. Nao há registro de fontes de alimentação e, as baterias são raras. Não são registrados equipamentos de comunicação sem fio ou de equipamentos de segurança. A lista de REEE de todos os tipos cresce proporcionalmente ao de novidades lançadas no mercado. Esses fatos induzem a constatação de que é necessário repensar os critérios de Administracao Patrimonial, para a inclusão desses itens no sistema. Uma alternativa seria de se criar subsistemas sistemas de informação para cada setor, como de compras, manutenção, informática, zeladoria, almoxarifado e outros, que fossem integrados ao sistema principal. 


\subsection{SISTEMA DE GESTÃO DE REEE NA UCA}

Com transposição das Diretivas WEEE e RoSH da UE para a legislação espanhola, mediante o RD 208/2005, foi estabelecido o prazo de um ano para a adaptação de todos os atores envolvidos com os REEE à nova lei. Desde o ano de 2006, a gestão desses resíduos na UCA passou a ser de competência do Serviço de Prevenção, ligado à Vice-Reitoria de Infraestrutura, que já tinha sob sua responsabilidade o gerenciamento dos resíduos perigosos, incluindo pilhas, baterias, cartuchos de tinta e tubos fluorescentes. Por outro lado, o Departamento Oficina Verde, ligado à Gerência Administrativa é responsável pela gestão ambiental na instituição, iniciou uma campanha de conscientização dirigida à comunidade universitária, para estimular a coleta seletiva na instituição.

Ambos os departamentos têm se esforçado em cumprir da melhor maneira possível, seus papeis na gestão dos REEE gerados na UCA, cada um com sua visão e missão. Contudo, as diferentes interpretações da Diretiva WEEE da UE, de sua transposição para a legislação nacional e das adaptações para as leis regionais e municipais, podem dar margem a dúvidas e gerar confusões. Observou-se que a campanha de comunicação se iniciou com vulnerabilidades que podem levar à desorientação do público alvo. Além de produzir material de divulgação de maneira independente, cada setor distribuiu seus próprios coletores para pilhas, cartuchos e outros resíduos, de modelos diferentes entre si. As Figuras 31 a 34 exemplificam algumas das medidas adotadas para o gerenciamento dos REEE na UCA.

Figura 31 - Coletor de pilhas do Serviço de Prevenção

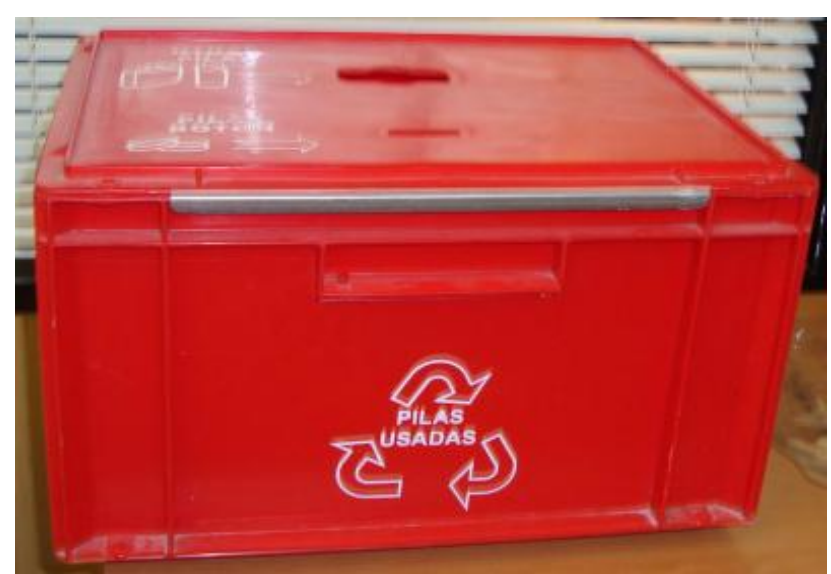

REIDLER, 2011 
Figura 32 - Coletor de pilhas, cartuchos e toners da Oficina Verde, da Gerência Administrativa

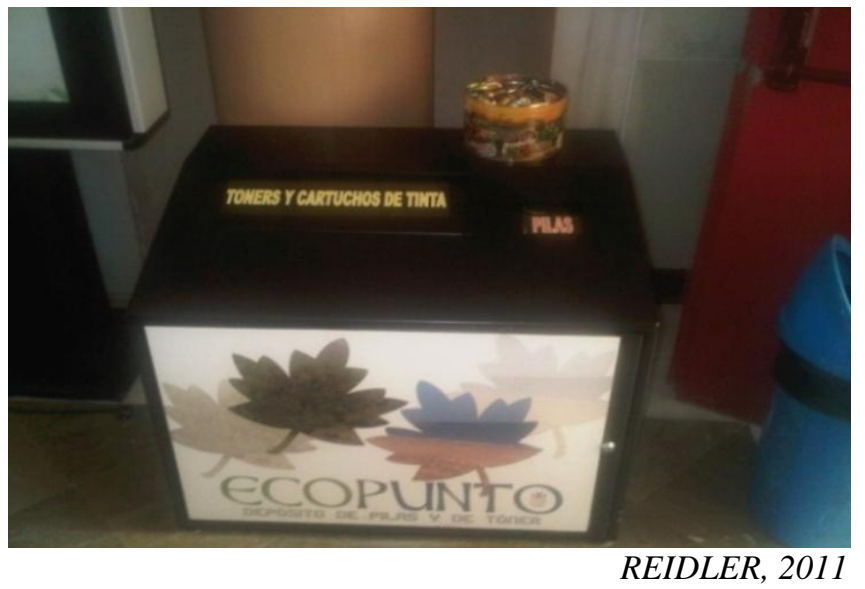

Figura 33 - Coletor de pilhas, cartuchos e toners da Oficina Verde (detalhe)

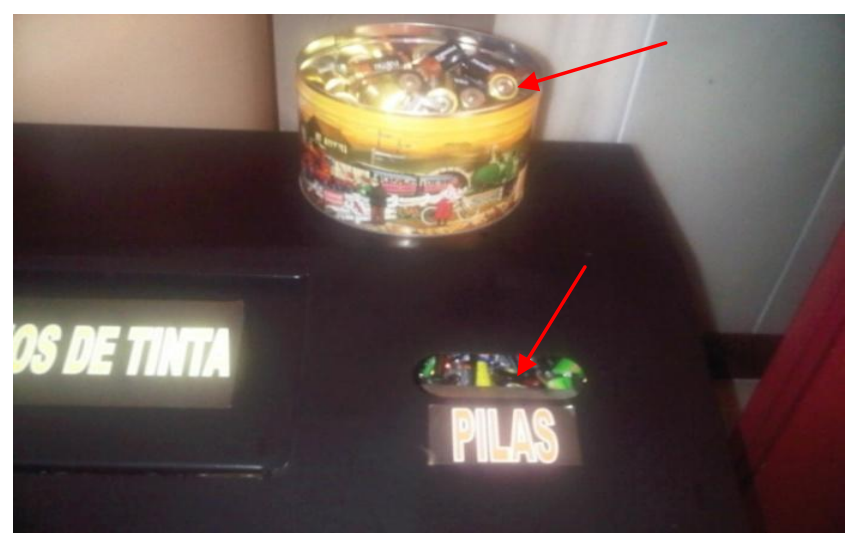

REIDLER, 2011

Figura 34- Punto Verde - Ponto de Coleta Seletiva da Gerencia Administrativa, com coletores para pilhas, cartuchos e outros resíduos

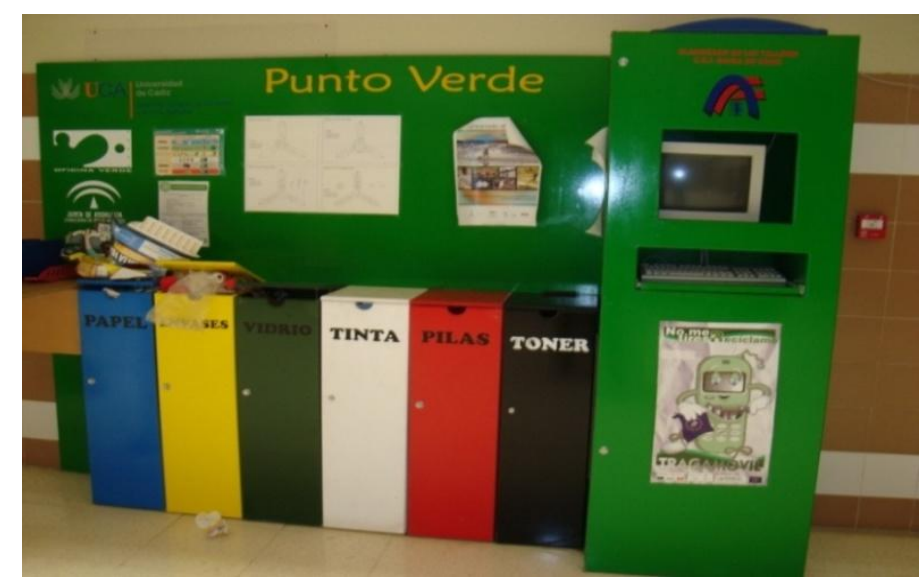


Considera-se que, ao se integrar ações de gerenciamento e medidas adotadas sobre um mesmo tema, por diferentes setores dentro da instituição, poder-se-ia produzir um sistema de gestão mais eficiente e evitar gastos desnecessários. A integração de ações de setores-chave como e Gerência Administrativa, Compras, Administração Patrimonial, Prevenção, Gestão Ambiental, Saúde do Trabalhador e Segurança e outros, traria benefícios em termos de comunicação, gestão integrada e de ganhos de economia de escala ${ }^{7}$. Observa-se que a estrutura organizacional, definida no organograma da instituição, se perde na prática e os setores acabam atuando de maneira independente. A dificuldade em se obter dados sugere uma falta de interesse em disponibilizar ou em divulgar informações que poderiam ser de grande utilidade para a elaboração de um plano de gestão integrada dos REEE da instituição. A integração dos sistemas de informação, com padronização de procedimentos, permitiria monitorar os dados em tempo integral e corrigir eventuais falhas no sistema de gestão, com vistas à melhoria contínua. $\mathrm{O}$ sistema de informação gerencial reformulado para atender às necessidades de setores-chave envolvidos com a gestão desses resíduos, pode constituir ferramenta de grande utilidade para um sistema de gestão integrada eficiente e com conformidade legal garantida. As IES, como geradoras de conhecimento e formadoras de opinião, têm a oportunidade única de poder contar com especialistas em todos os campos do conhecimento em seu capital humano e têm a obrigação de liderar a mudanças de comportamento rumo à sustentabilidade, considerando seus aspectos fundamentais.

\subsubsection{Geração de REEE na UCA}

Verificou-se que os dados produzidos de forma independente pelo Serviço de Prevenção da UCA são utilizados apenas para seu próprio controle e que não são divulgados formalmente. O Serviço de Prevenção providencia a coleta dos REEE gerados em todos os Campi da instituição, os quais são armazenados em caçambas localizadas no Centro de Transferência de Resíduos da UCA, situado no Campus de Puerto Real. Para a coleta e transporte até os gestores finais, são contratados gestores intermediários. É possível que essa não seja a melhor prática do ponto de vista da logística, considerando-se que o mesmo material seja transportado duas vezes e a gestão cobrada por dois prestadores de serviço.

\footnotetext{
7 Economia de escala é aquela que resulta de ser organizar o processo produtivo de maneira que se alcança a máxima utilização dos fatores produtivos envolvidos no processo, procurando como resultado baixos custos de produção e o incremento de produção de bens e serviços.
} 
Como grande geradora, talvez fosse mais produtivo negociar diretamente com os gestores finais, que se encarregariam da coleta e transporte diretamente dos campi, haja vista a localização dos mesmos em diferentes cidades. Um fato que chama à atenção é a falta de controle sobre a quantidade real de REEE que se encaminha para a gestão externa, uma vez que esse serviço é cobrado por peso de material coletado e o valor a ser pago é informado por gestores intermediários. O controle do material que sai da instituição poderia reduzir os custos da gestão externa.

Na UCA, os dados de geração e destino dos REEE encaminhados para gestão externa são registrados desde 2006, de maneira informal. A coleta desses resíduos por gestores intermediários é realizada semestralmente. Os dados de volume em peso são resumidos na Tabela 14.

Tabela 14 - REEE gerenciados pelo Serviço de Prevenção da UCA (2006 - 2010)

\begin{tabular}{ccr}
\hline ANO & GESTOR EXTERNO & PESO (Kg) \\
\hline $\mathbf{2 0 0 6}$ & VERINSUR & 10860,00 \\
$\mathbf{2 0 0 7}$ & VERINSUR & 6780,00 \\
$-\mathbf{2 0 0 8}$ & MAEX - XXI & $-9520,00$ \\
$\mathbf{2 0 0 9}$ & MAEX - XXI & 360,00 \\
$\mathbf{2 0 1 0}$ & FCC - AMBITO & 3830,00 \\
\hline TOTAL & $\mathbf{3 1} \mathbf{5 0 , 0 0}$ \\
\hline${ }^{*}$ Dados fornecidos pelo Serviço de Prevenção da UCA, no primeiro semestre de 2010.
\end{tabular}

\subsubsection{Comparação entre os dados levantados no Sistema de Informação da} Administração Patrimonial e os fornecidos pelo Serviço de Prevenção da UCA

No Sistema de Informação da Administração Patrimonial da UCA não são registradas informações sobre os pesos dos bens, nem sobre os seus destinos após o processo de baixa patrimonial. Por outro lado, o Serviço de Prevenção registra apenas os destinos e as quantidades dos REEE encaminhados para gestão externa. Desse modo, a única comparação possível de ser feita é entre as quantidades de REEE geradas (estimadas) por ano e as quantidades encaminhadas para a gestão externa, conforme o resumido na Tabela 15. 
Tabela 15 - Comparativa entre os pesos médios anuais de REEE da UCA

\begin{tabular}{lcc}
\hline ANO & SICOC: BAIXAS $(\mathbf{K g})$ & SERVIÇO DE PREVENÇÃO $(\mathbf{K g})$ \\
\hline $\mathbf{2 0 0 6}$ & 36012,20 & 10860,00 \\
$\mathbf{2 0 0 7}$ & 3844,40 & 6780,00 \\
$\mathbf{2 0 0 8}$ & 3722,10 & $-9880,00$ \\
$\mathbf{2 0 0 9}$ & 3892,20 & 3830,00 \\
$\mathbf{2 0 1 0}$ & 3242,10 & $\mathbf{3 1 3 5 0 , 0 0}$ \\
\hline TOTAL & $\mathbf{5 0 7 1 3 , 0 0}$ &
\end{tabular}

REEE gerados entre 2006-2010, estimados com base nos dados obtidos em levantamento realizado no Sistema de Informação da Administração Patrimonial e em dados fornecidos pelo Serviço de Prevenção da UCA

Os dados se referem aos mesmos REEE, gerados no mesmo período (2006 a 2010), obtidos das duas fontes de informação provenientes de dois setores administrativos, da mesma instituição. Na comparação, obtem-se uma diferença de aproximadamente $62,0 \%$ em peso entre os resultados, em um período de cinco anos. Essa discrepância entre os resultados obtidos das duas fontes sugere uma falta de controle sobre o tipo de material encaminhado para a gestão externa. Verificou-se que parte dos REEE é misturada com outros tipos de resíduos volumosos (Figuras 38 a 40) e enviado a aterros para disposição no solo. Essa prática pode estar sendo utilizada para diminuir os custos da gestão final dos REEE gerados na instituição.

Os dados fornecidos pelo Serviço de Prevenção foram extraídos de certificados de gestão ou de destruição emitidos por gestores intermediários, contratados para a gestão externa dos REEE da UCA "segundo os condicionantes ambientais aplicáveis e as exigências da normativa vigente." Entretanto, esses certificados não informam sobre o destino ou métodos de tratamento desses resíduos, o que implica na impossibilidade de monitoramento e de rastreamento. As informações sobre destino e quantidades são relatadas por contratados, que cobram por seus serviços com base no peso de REEE coletados, sem que o contratante tenha um controle sobre a veracidade da informação e sem conferir o peso dos REEE enviados para a gestão externa. A instituição deveria considerar todo o ciclo de vida de seus EEE, antes e após sua vida útil. Isso nem sempre acontece. Os dados fornecidos pelo Serviço de Prevenção não incluem, as empresas não autorizadas para essa atividade, que retiram os REEE misturados com outros tipos de resíduos volumosos, conforme se pode observar nas Figuras 35 a 37. 
Figura 35 - Transporte de REEE, misturado com outros tipos de resíduos em caminhão de mudanças

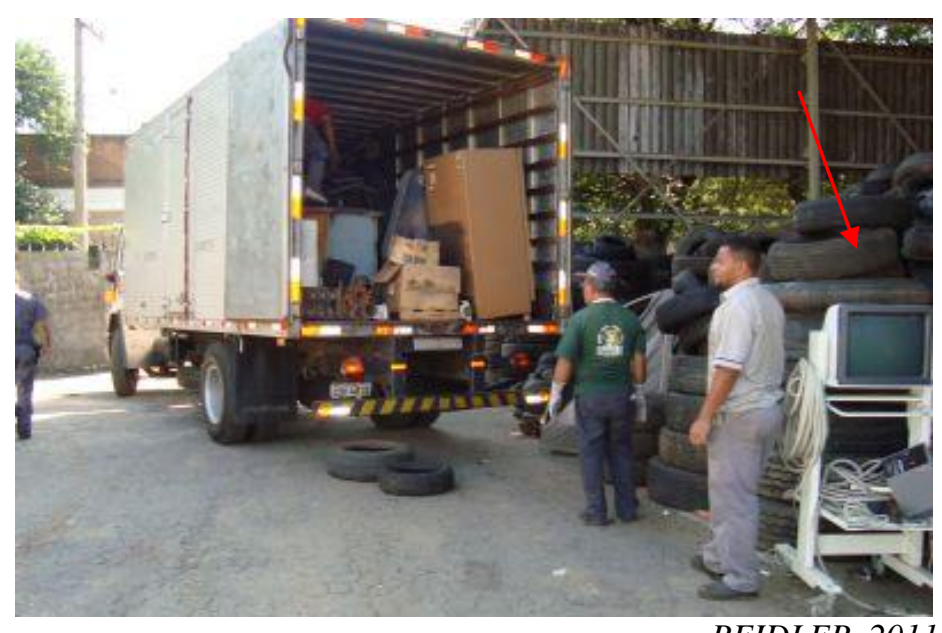

REIDLER, 2011

Figura 36 - Transporte de REEE misturados com resíduos volumosos

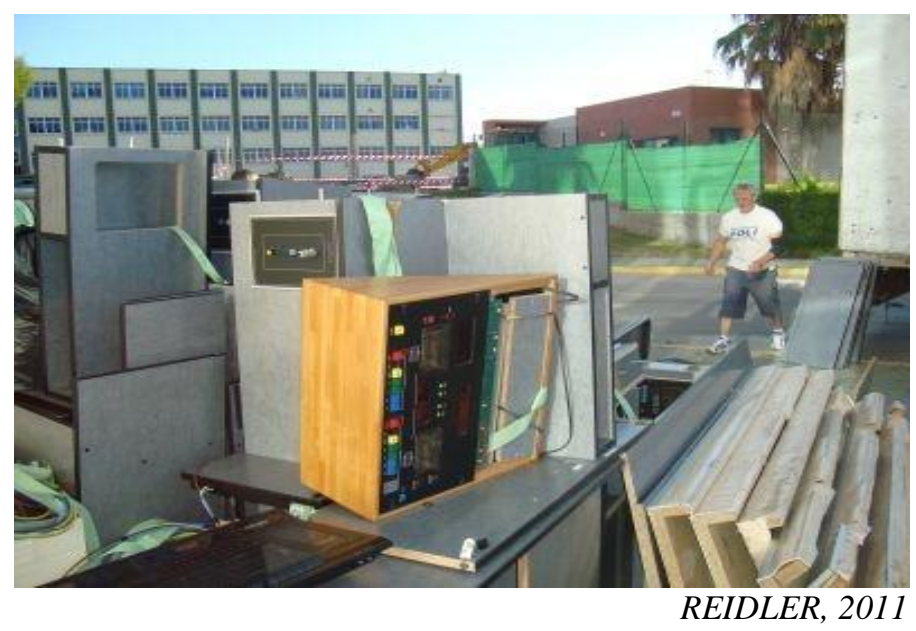

Figura 37 - REEE carregados em caçamba de empresa de remoção de entulhos para enviar a aterro

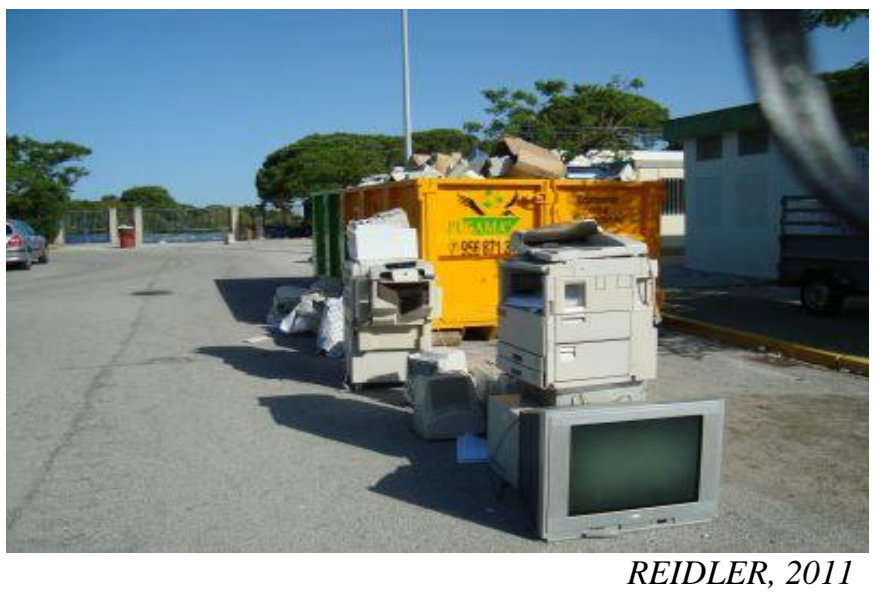


No gerenciamento interno observaram-se também ações proativas, algumas promovidas pela Cátedra RELEC e outras, pelo Departamento de Gestão Ambiental Oficina Verde, mas a falta de coordenação entre os setores resulta em esforços infrutíferos e recursos desperdiçados na tentativa de se construir um sistema de gestão integrada e sustentável de REEE na instituição.

Em 2010, a UCA firmou um contrato com a AMBILAMP, o SIG de REEE autorizado para a gestão de lâmpadas e tubos fluorescentes em nível nacional. No início não se notou um impacto econômico positivo, em função de que as lâmpadas e tubos, até então, estavam sendo destinadas junto com os outros REEE. Observa-se na Figura 38, o carregamento de REEE misturados com lâmpadas fluorescentes, realizado por funcionários do Serviço de Prevenção da instituição, para encaminhar a aterro de inertes localizado em Los Barrios, segundo as informações obtida na ocasião.

Figura 38- Centro de Transferência de Resíduos da UCA no Campus de Puerto Real

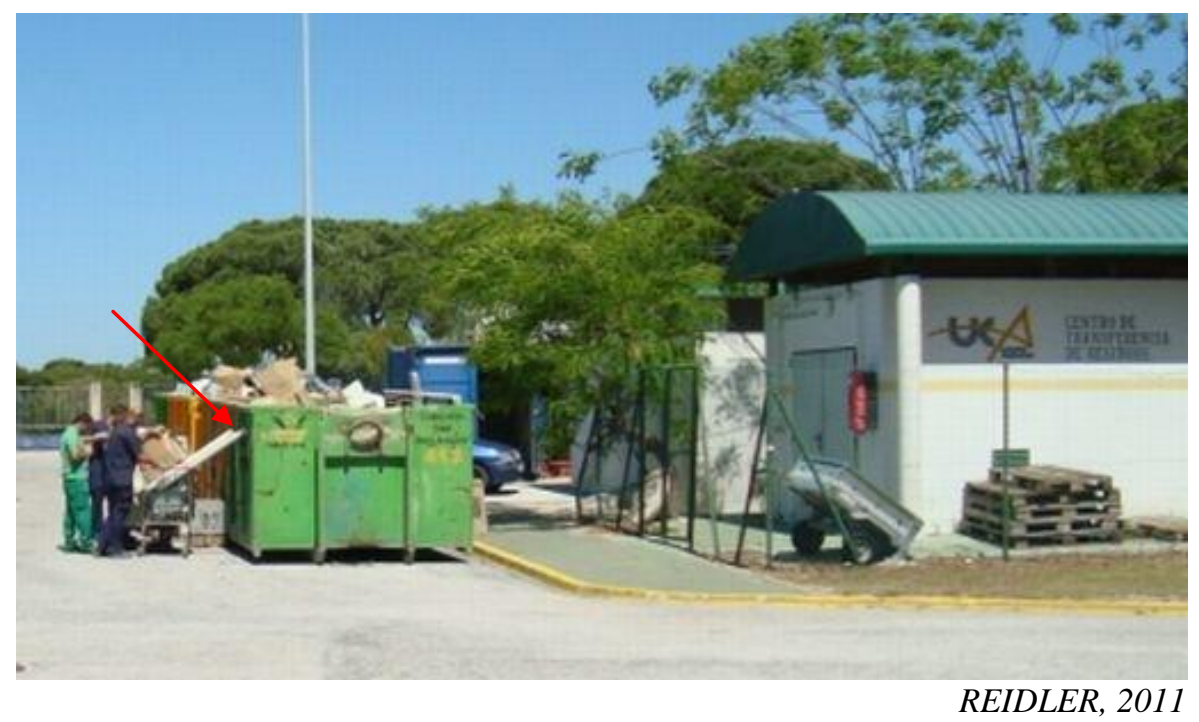

\subsubsection{Projeto piloto de gestão de REEE no Campus de Puerto Real}

Uma campanha de coleta seletiva de REEE, promovida na UCA em parceria da Cátedra RELEC com todos os SIG de REEE, deu inicio ao projeto piloto de gestão integrada desses resíduos no Campus de Puerto Real. A ideia de fazer uma exposição rotativa, percorrendo todas as unidades da instituição trouxe grande visibilidade ao projeto. Essa experiência mostrou importância de IES como formadora de opinião e seu poder de 
negociação com fornecedores e prestadores de serviços. Quando um SIG se propôs a colaborar, todos os outros se mostraram interessados em participar, com fornecimento de material de comunicação para a campanha mostrada na Figura 39, além de prestar serviços sem custo para o projeto piloto, para impulsionar a gestão desses resíduos na instituição.

Figura 39 - Campanha de coleta Seletiva de REEE da RELEC, no saguão de entrada principal da UCA, no Campus de Puerto Real

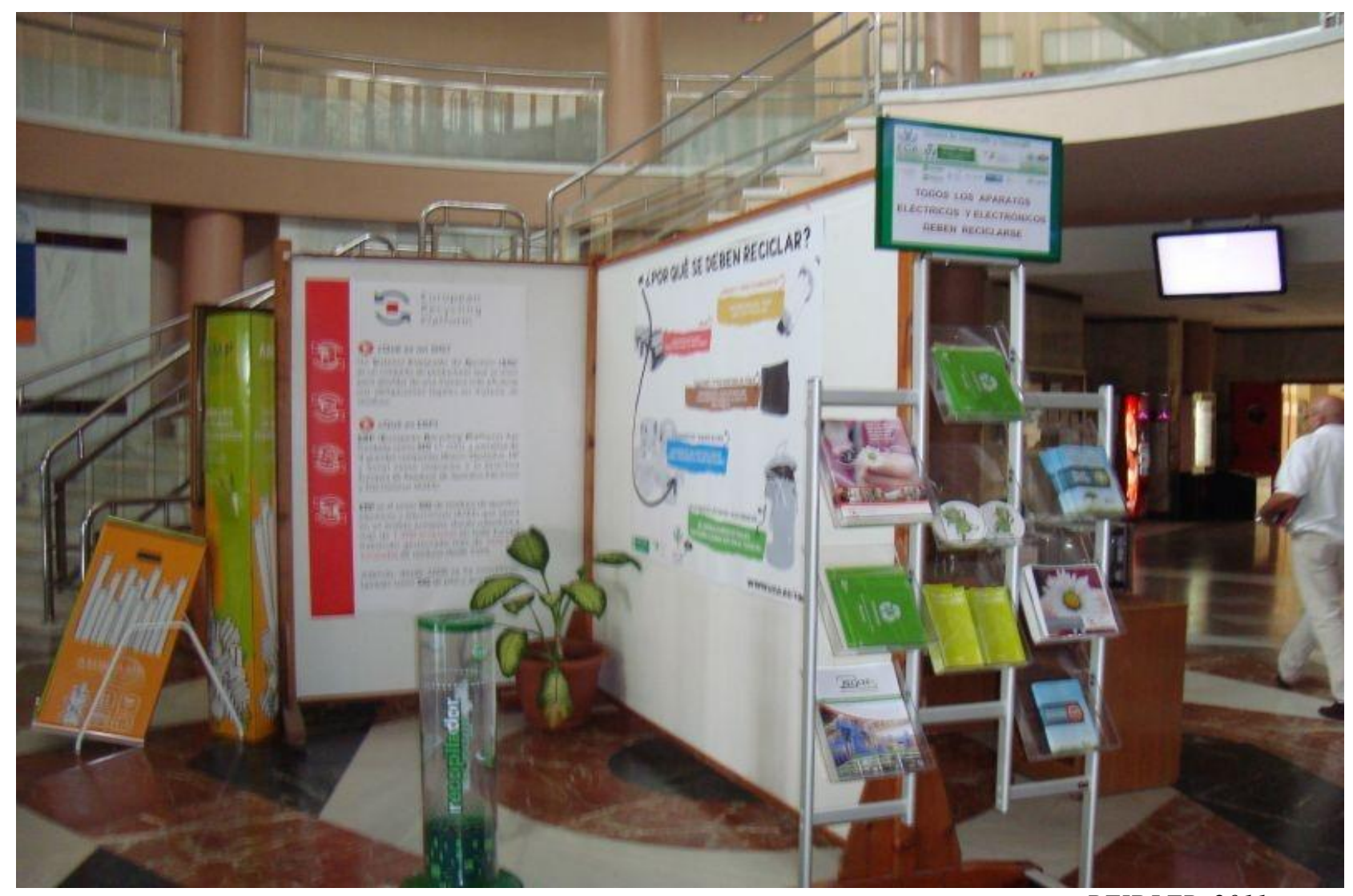

REIDLER, 2011

Embora a reciclagem de lâmpadas seja cobrada por unidade, foi acordado por intermédio da Cátedra RELEC da UCA, que a AMBILAMP forneceria os contêineres apropriados e passaria a coletar esse material sem custos.

O SIG ECOTIC, especializado em gestão de REEE de TIC também participou do plano piloto, disponibilizando coletores de pequenos EEE em pontos estratégicos (Figura 40) e jaulas para segregação por tipo de REEE. A empresa RECILEC, gestor final de REEE em Andaluzia, se encarregaria da logística reversa e tratamento dos REEE gerados na UCA. 
Figura 40 - Coletor de pequenos REEE na parte externa do edifício principal do Campus de Puerto Real, ao lado da Cafeteria

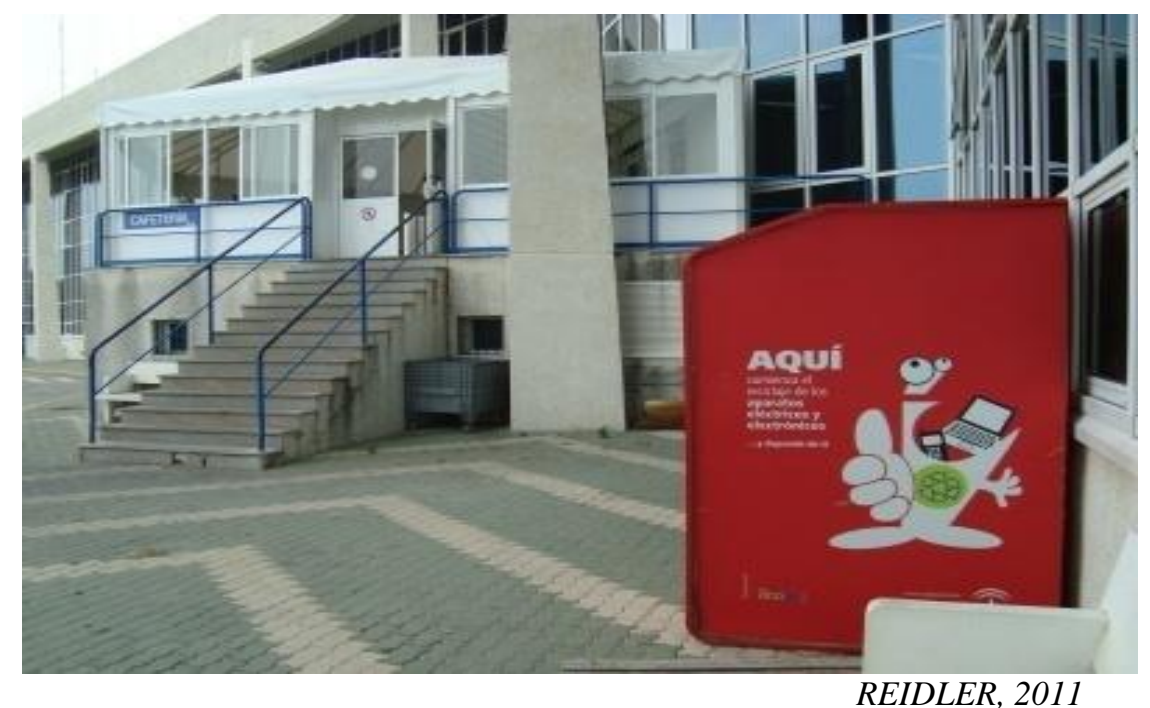

\subsubsection{Gestão de REEE na UCA}

A gestão de equipamentos de iluminação, baterias, fontes de alimentação, componentes e outros REEE considerados de materiais de consumo é uma incógnita, tanto na UCA como na USP. As informações são difusas e confusas e, os dados inexistentes. Vale lembrar que esses REEE contêm metais pesados e outras substâncias tóxicas para a saúde e para humana para o meio ambiente. Além da falta de conhecimento do destino de grande parte do destino de grande parte dos REEE gerados nas duas instituições investigadas, há unanimidade entre os entrevistados, de diferentes setores envolvidos com o tema, que grande parte dos EEE não é registrada no patrimônio, por inúmeras razões. As mesmas informações foram obtidas, de maneira extraoficial, em outras instituições visitadas. Constatou-se que o fator cultural tem grande influência na gestão de REEE institucional. Verificou-se que os REEE de consumo ou não registrados no sistema de informação SICOC tem um fluxo distinto daqueles baixados do patrimônio. Esse fato evidencia a necessidade de um registro que inclua todos os REEE e confirma o potencial de um sistema de informação gerencial como ferramenta de grande utilidade na gestão desses resíduos.

Paralelamente, observou-se influência do fator cultural no desempenho da gestão. Em outros estados membros da UE, como por exemplo, Alemanha, Bélgica, e Suécia, não se discutem metas de $\mathrm{kg} / \mathrm{hab}$./ano, pois todos os REEE devem ser coletados e destinados conforme as determinações legais (PECHARDS, 2005). Para esses países, onde já existia legislação sobre o tema antes das diretivas WEEE e RoHS, a preocupação com o meio 
ambiente e com a saúde pública é um fator cultural. Por outro lado, para países que não possuíam nada em termos de regulamentação desses resíduos, como Espanha, Grécia, Portugal e Itália, a transposição das Diretivas da UE para a legislação nacional tem sido um processo longo e difícil, pois inclui mudança de comportamento. Pode-se concluir que a legislação é necessária e importante, mas não suficiente para o bom desempenho de um sistema de gestão integrada de REEE em uma organização. As Figuras 41 e 42 ilustram a influência do fator cultural na gestão dos REEE institucionais.

Figura 41 - REEE abandonado em corredor da UCA

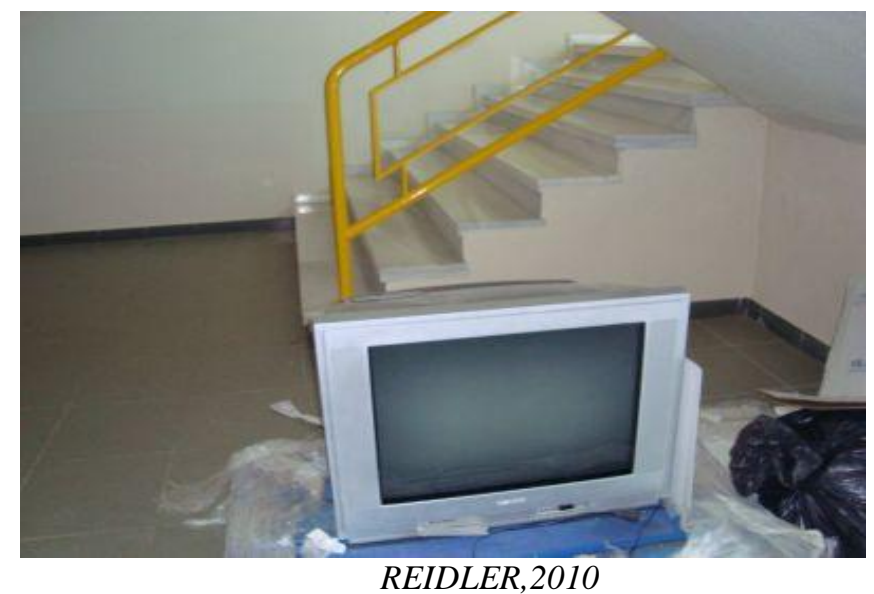

Figura 42 - REEE perigoso armazenado em área de trânsito na UCA

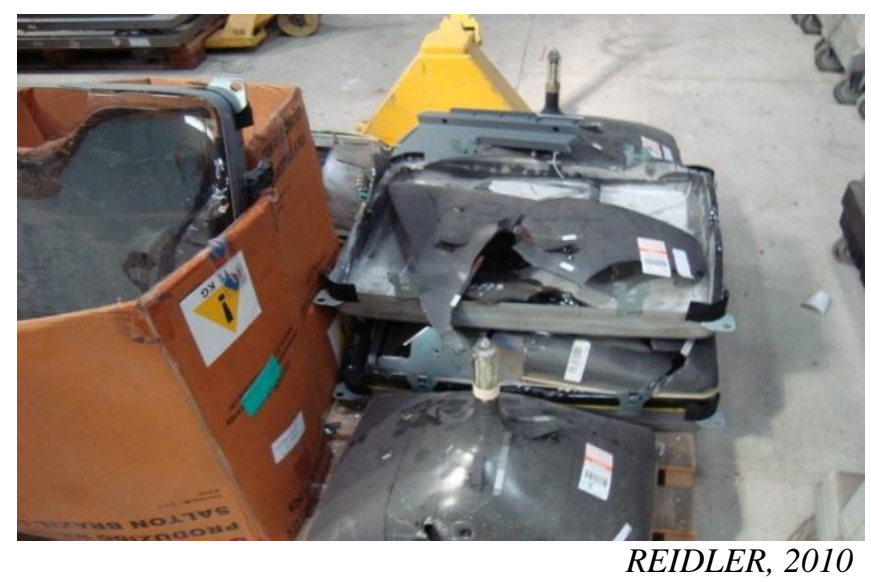

Constatou-se que, apesar de seu prestígio e credibilidade como referência em REEE na Espanha e em toda a Europa, a Cátedra RELEC da UCA sozinha não consegue implementar um sistema de gestão integrada de REEE na instituição. A falta de coordenação administrativa entre os setores resulta em obstáculo para o conhecimento da real dimensão da geração e do controle sobre o gerenciamento interno e fluxo e destino dos REEE gerados. 
Observou-se que o descarte irregular segue ocorrendo e oferecendo riscos à saúde e ao ambiente. Além da campanha de comunicação, é fundamental que se promova a capacitação do pessoal encarregado por esses resíduos e a conscientização dos usuários dos EEE. Qualquer que seja a teoria que venha a orientar um sistema de gestão integrada é preciso sempre considerar o fator humano como o foco central, para que se consiga um bom desempenho.

\subsubsection{Fluxo externo dos REEE gerados na UCA}

Esta etapa consistiu na investigação do caminho percorrido pelos REEE desde o momento de sua saída da instituição, após os procedimentos de baixa patrimonial, até seu destino. Após o processo de baixa, esses bens, que adquirem status de inservíveis, devem ser destinados de acordo com a legislação, segundo suas características. Os dados de destino dos REEE não são registrados no sistema de informação gerencial e foram levantados em pesquisa documental, realizada no Setor de Prevenção, que tem entre suas funções a responsabilidade de gerenciar os resíduos perigosos da UCA. As visitas foram realizadas segundo as necessidades indicadas na análise de dados das etapas anteriores. Antes de avaliar o nível de gestão atual dos REEE foram identificados os dados históricos associados aos indicadores, fluxo externo e destinação final desses resíduos.

Esses dados proporcionaram melhor visão do problema e foram fundamentais como ponto de partida para investigar o fluxo desses resíduos, com abordagem qualitativa. As visitas técnicas, com entrevistas informais, foram realizadas com o objetivo de conhecer o verdadeiro fluxo de REEE e as atuações dos envolvidos com sua gestão. Segundo se conseguiu apurar, até 2005, todos os REEE eram encaminhados para a disposição em aterros de inertes ou controlados. A partir de 2006, para cumprir as exigências impostas pelo RD 2008/2005, teve início a contratação de gestores intermediários para fazer a gestão externa dos REEE gerados na instituição. Com base nas observações e informações obtidas, identificaram-se os principais gestores intermediários e verificou-se que, muitas vezes, esses não são autorizados a exercer essa atividade de gestão externa de REEE.

O único gestor entre os identificados nesta pesquisa, com autorização para realizar tal atividade, foi a FCC-AMBITO. A empresa realiza a coleta na Estação de 
Transferência de Residuos da UCA e leva os REEE coletados para uma planta de classificação e disposição final localizada em Los Barrios, na Provincia de Cádiz. Parte dos REEE resultantes da triagem é encaminhada para planta da RECILEC, gestor final de REEE autorizado pelos SIG e parte é destinada ao aterro de inertes. Segundo estudo realizado pela Organización de Consumidores y Usuários (OCU, 2011), apenas 20\% desses REEE são encaminhados para a reciclagem e o restante é depositado no solo.

Observou-se que, da mesma forma como ocorre no Brasil, na Espanha é comum a manipulação de REEE em locais não autorizados, onde se retiram os componentes com valor agregado e se deposita o "rejeito" de qualquer maneira, sem controle. Os metais são vendidos aos sucateiros e as placas de circuito impresso, que possuem uma grande demanda, comercializadas no mercado paralelo de reciclagem, para a recuperação de substâncias valiosas.

Sabe-se que os REEE descartados sem controle podem conter substâncias perigosas como gases de refrigeração, óleos minerais com bifenilas policloradas (de lavadoras, compressores, etc.) metais pesados (provenientes de lâmpadas, baterias, monitores e televisores) entre muitos outros representam riscos ambientais e à saúde pública. Ocorre que apenas especialistas e atores diretamente envolvidos com o "negócio" da gestão tem conhecimento dessa informação. A grande maioria dos usuários afirma já ter ouvido que esses resíduos não devem ser descartados no lixo comum, mas não sabem exatamente o motivo. Muitas vezes, embora os intermediários e os sucateiros tenham esse conhecimento, retiram do REEE apenas os componentes que tenham algum valor agregado e que possam ser vendidos. Desprezam materiais que poderiam ser descontaminados e reciclados sem levar os potenciais impactos negativos que essa ação pode causar. Em nenhum caso há controle sobre o descarte dos rejeitos.

\subsubsection{Visita à planta de reciclagem RECILEC}

A RECILEC é o gestor final de REEE autorizado por todos os SIG de REEE da Espanha para Andaluzia e Extremadura. A visita à planta de reciclagem da empresa teve o objetivo de verificar o fluxo oficial dos REEE baixados do patrimônio da UCA. Em operação desde 2005 e localizada em Aznalcóllar (Sevilla), a RECILEC é a maior 
planta de tratamento de REEE da Espanha. Conta também com um Centro Periférico em Loja (Granada), especializado em classificação de pilhas e acumuladores e no tratamento de equipamentos de ar condicionado. Uma nova planta com capacidade para 5000 t/ano, recém-inaugurada em Mérida (Extremadura), está capacitada para reciclar equipamentos com gases de refrigeração, descontaminar grandes eletrodomésticos, reciclar televisores de todos os tipos e classificar pilhas e acumuladores. A empresa é especializada em logística reversa e tem experiência em reciclagem de todos os tipos de REEE. Do controle acionário da empresa participam uma empreiteira (que atua também como gestor intermediário de REEE), a Indumetal Recycling, que recupera metais de placas de circuito impresso e recicla pilhas e baterias, e a Agencia de Meio Ambiente e Agua de Andaluzia, (equivalente à Secretaria Estadual de Meio Ambiente).

- RECILEC - Planta de Tratamento de REEE em Mérida: em sua primeira fase, a nova planta conta com cinco linhas de tratamento: equipamentos com gases de refrigeração; descontaminação de grandes eletrodomésticos; duas linhas de classificação diferentes, para televisores e monitores de vídeo (para TRC, LCD e de plasma); e uma linha específica para a classificação de pilhas e acumuladores, que, posteriormente, são enviadas à planta de reciclagem da parceira Indumetal Recycling.

A recicladora fornece jaulas aos grandes usuários, para que esses façam a coleta seletiva por categoria operacional com segregação na origem antes de encaminhá-lo para a gestão externa. Dessa maneira, o material a ser reciclado já chega à planta separado e é direcionado à respectiva linha de desmontagem. A primeira fase do tratamento consiste na remoção dos componentes que possam conter mercúrio ou chumbo, ao mesmo tempo em que se executa uma classificação dos resíduos em função de sua destinação final. Após a segregação e descontaminação desses resíduos, as frações obtidas são submetidas a processos de moagem e trituração, para em seguida serem tratadas por processos físico-mecânicos, nos quais se obtêm matérias-primas como o cobre, o ferro e o alumínio, entre outros, para reinserir nos ciclos de produção. A Figura 43 ilustra o funcionamento de uma linha de desmontagem e tratamento de monitores de vídeo, na planta de reciclagem da RECILEC, em Aznalcóllar, na Espanha. 
Figura 43 - Linha de classificação de REEE na RECILEC
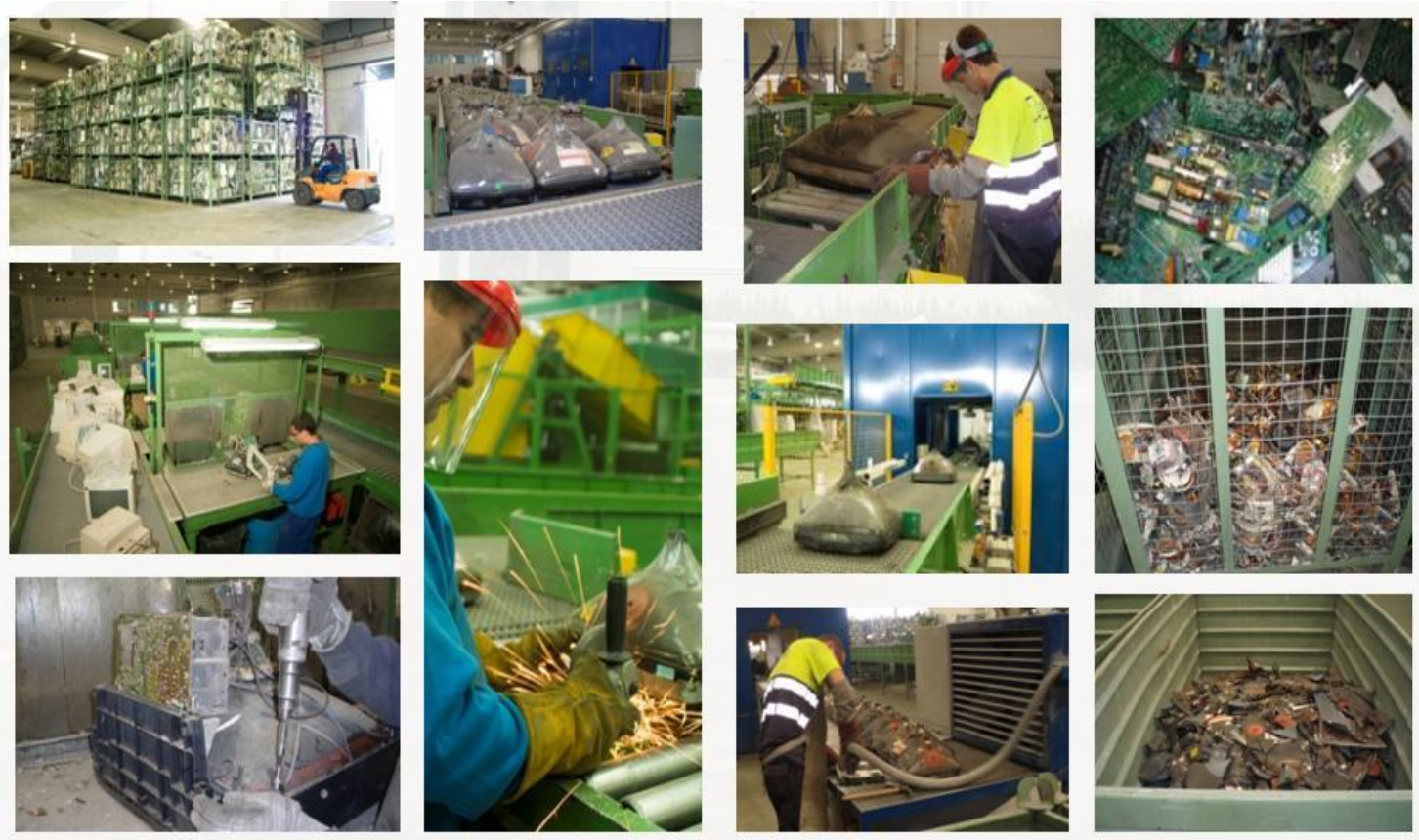

RECILEC, 2011

Há muitas plantas de tratamento e reciclagem de REEE na Espanha, utilizando diferentes tipos de tecnologia. Basicamente, os tratamentos utilizados na reciclagem de REEE, após desfragmentação de seus componentes são:

1. Fração complexa rica em materiais: classificação, moagem e separação por processos mecânicos e eletromagnéticos, para separar os metais com a obtenção de ligas que possam ser reutilizadas como matérias-primas secundárias. Há também a opção de se utilizar o processo de gaseificação ou de pirólise para separar os metais.

2. Fração de vidro: o chumbo de muitas das frações complica a reciclagem do vidro, principalmente as dos TRC. Atualmente essa separação não é possível. Portanto, ou se recicla esse material em empresas que utilizem esse tipo de vidro com chumbo, ou gera-se um resíduo que deve ser inertizado e descartado em aterro.

3. Fração de plástico: Em cumprimento à Diretiva RoHS, esses produtos não podem conter cádmio, chumbo, cromo, mercúrio ou compostos com aditivos retardantes de chama. Portanto, esses plásticos não contaminados seguem o processo normal de reciclagem. 
A descontaminação de lâmpadas e tubos fluorescentes é feita sob pressão negativa e não há exposição do trabalhador a substâncias tóxicas. Os componentes metálicos são reciclados e as substâncias químicas recuperadas são vendidas e reinseridas no processo produtivo. O vidro, após ser descontaminado e triturado, pode ser misturado em materiais de construção ou enviado para disposição no solo. A Figura 44 mostra as diferentes etapas da reciclagem de lâmpadas e tubos fluorescentes.

Figura 44 - Linha de Tratamento de Lâmpadas Fluorescentes
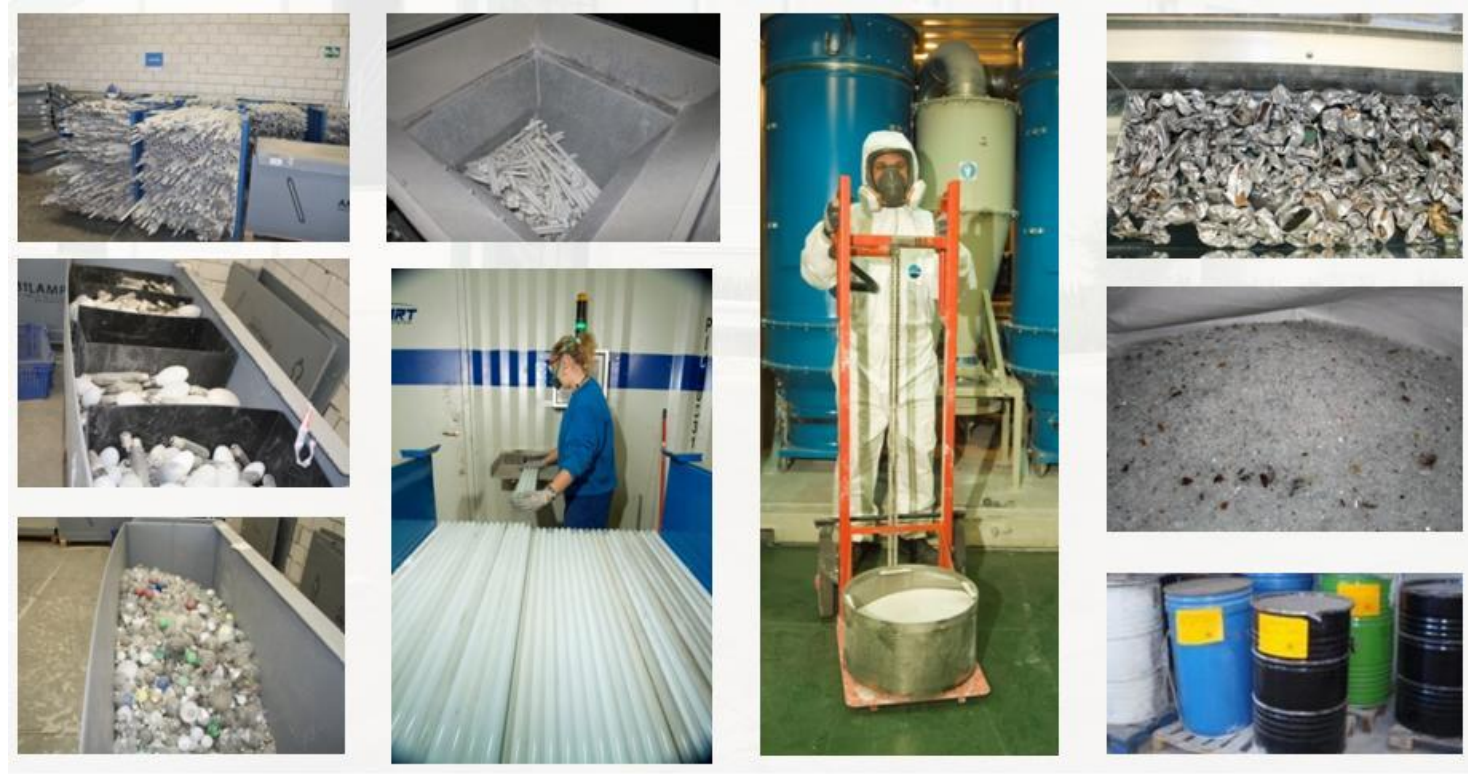

RECILEC, 2011

Os funcionários utilizam EPIs e trabalham dentro das normas de segurança e de proteção à saúde do trabalhador, conforme se pode observar nas Figuras 45 a 46.

Figura 45 - Reciclagem de monitores de TRC

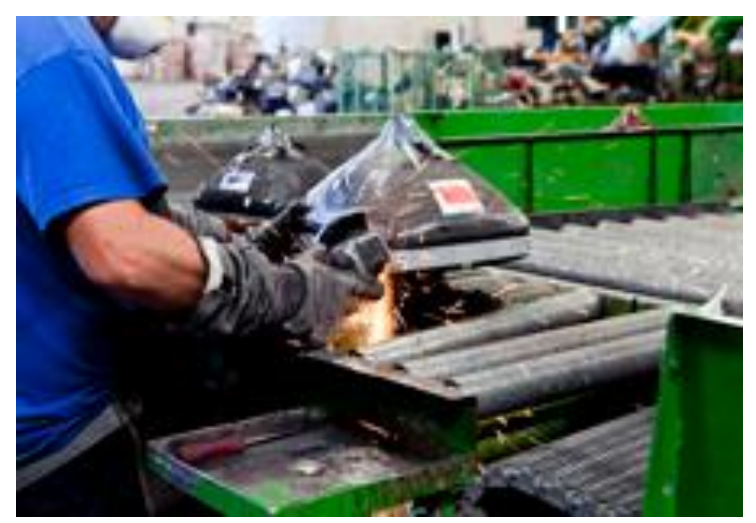

REIDLER, 2011 
Figura 46 - Uso obrigatório de EPIs em todas as etapas do tratamento e reciclagem de REEE

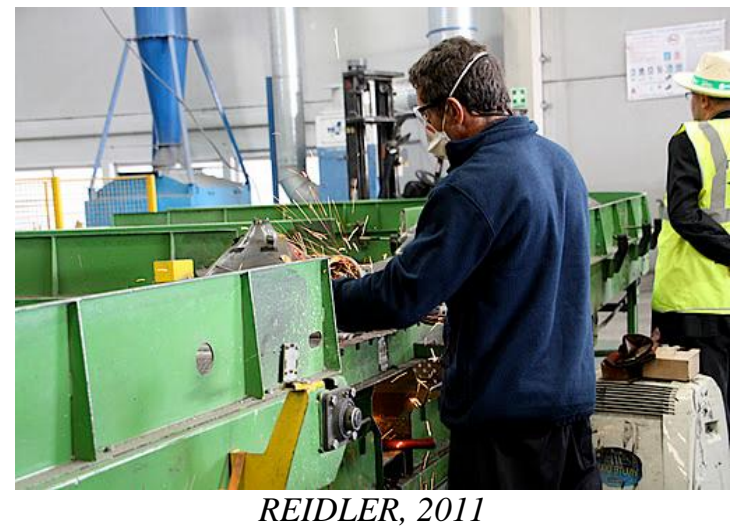

\subsection{SISTEMAS INTEGRADOS DE GESTÃO NA ESPANHA}

Para se conseguir um sistema de reciclagem de REEE realmente efetivo, é fundamental o envolvimento de todos os agentes que participam da cadeia de geração e de sua coleta: cidadãos, entidades locais, distribuidores e fabricantes. Entretanto, a Diretiva 96/2002/CE da UE e o Real Decreto 208/2005, que transpõe essa diretiva ao ordenamento jurídico espanhol, entendem que a responsabilidade principal recai sobre o produtor. Para fazer frente a essas obrigações, os produtores (fabricantes e importadores) se associam para criar entidades sem fins lucrativos que se responsabilizem pela correta gestão dos produtos colocados no mercado, ao final de sua vida útil. Essas entidades se denominam Sistemas Integrados de Gestão (SIG) (REVERTIA, 2010). De acordo com a Diretiva WEEE, os produtores deverão estabelecer sistemas para a coleta de REEE que não procedam de domicílios particulares e para seu transporte aos centros de tratamento autorizados. O produtor será responsável pela gestão de seus REEE. Na Espanha, foram constituídos diversos SIG para garantir a gestão dos REEE, conforme o determinado na normativa. Com o objetivo de entender o funcionamento dos Sistemas de Gestão Integrada de REEE a nível nacional, foram realizadas visitas técnicas aos principais SIG da Espanha, facilitadas e intermediadas pela Cátedra RELEC e resumidos a seguir: 
- AMETIC: SIG sem fins lucrativos nascido da fusão, em outubro de 2010, dos SIG AETIC e ASIMELEC. A nova patronal espanhola da eletrônica, das tecnologias da Informação, das telecomunicações e dos conteúdos digitais é uma integração associativa em seu âmbito em escala europeia. A Associação lidera, a nível nacional, a escala europeia, os interesses empresariais de um setor com mais de 5.000 empresas associadas, cuja atividade econômica se supõe em torno de 7\% do PIB espanhol (AMETIC, 2011).

- AMBILAMP: associação sem fins lucrativos que nasce como solução para a gestão de REEE de lâmpadas e tubos fluorescentes, reunindo as principais empresas de iluminação, com o objetivo de desenvolver um sistema de coleta e tratamento de REEE de lâmpadas (AMBILAMP, 2011).

- ECOASIMELEC: fundação sem fins lucrativos que dá cobertura às necessidades de gestão, tanto nos fluxos de resíduos de origem doméstica como profissional. Tem uma rede de centros de armazenamento temporário de REEE e de gestores em todo o território nacional. O número de pontos de coleta da Organização cresce constantemente, graças à progressiva incorporação de pontos na distribuição e dos Puntos Limpios à medida que se firmam acordos de colaboração com as Comunidades Autônomas e com os Ayuntamentos (Administração Municipal). A Fundação ECOASIMELEC congrega os SIG ECOFIMATICA, ECOPILAS e TRAGAMOVIL. (ECOASIMELEC, 2011).

- ECOLEC: sistema de gestão coletiva sem fins lucrativos, criado por associações empresariais que representam o setor de fabricantes e importadores de grandes e pequenos eletrodomésticos, com a finalidade de ser um sistema de financiamento coletivo de gestão de REEE na Espanha (ECOLEC, 2011).

- ECOLUM: fundação sem fins lucrativos, criada para o estabelecimento desenvolvimento e gestão de sistemas de coleta, tratamento, reutilização, reciclagem e valorização, especialmente de equipamentos de iluminação, lâmpadas e luminárias. Promove a cooperação de todos os agentes econômicos 
que devem assumir com sua parte de responsabilidade na geração e gestão de resíduos de equipamentos de iluminação, criando um SIG para dar resposta às obrigações legais das empresas associadas (ECOLUM, 2011).

- ECO-RAEEs: é uma fundação ambiental sem fins lucrativos, constituída para a criação e aplicação de um SIG de REEE, com a finalidade de apoiar a todos os produtores e empresas de EEE afetados pela Lei 50/2002 de 26 de dezembro de 2002, assim como pelo RD 208/2005 de 25 de fevereiro, sobre REEE e o RD 106/2008 sobre pilhas e baterias (ECO-RAEEs, 2011).

- ECOTIC: fundação privada, sem fins lucrativos, cuja constituição foi promovida por empresas do setor de eletrônica e faz a gestão de nove das dez categorias a 9 das 10 estabelecidas no DL 230/2004 (UE, 2004). Somente a gestão da categoria 5, não fazia parte de suas atividades. Recentemente, com o apoio da Associação de Fabricantes e Exportadores de Equipamentos de Iluminação - SELCI, a ECOTIC criou um novo SIG para a gestão de iluminação (luminárias), com o que passa a fazer a gestão de todas as categorias de REEE estabelecidas no RD 208/2005.

- ERP - European Recycling Platform: organização sem fins lucrativos constituída em dezembro de 2002, como um SIG paneuropeu para a coleta seletiva e reciclagem de REEE, com o objetivo de assegurar uma correta gestão e a reciclagem desses resíduos no continente. Ao longo dos anos, a ERP expandiu sua atividade para a coleta de pilhas e acumuladores pilhas e acumuladores e, para recipientes e embalagens de todos os tipos. Na Espanha foi fundada em 2005, como SIG de REEE e, atualmente, faz a gestão de pilhas e acumuladores. (ERP, 2011).

Os SIG distribuem coletores para diversos tipos de REEE, para coleta seletiva em pontos estratégicos, conforme o exemplificado nas Figuras 47 a 50. 
Figura 47 - Dois tipos de coletores de pilhas fornecidos aos usuários para a coleta seletiva (para grandes e pequenos usuários).
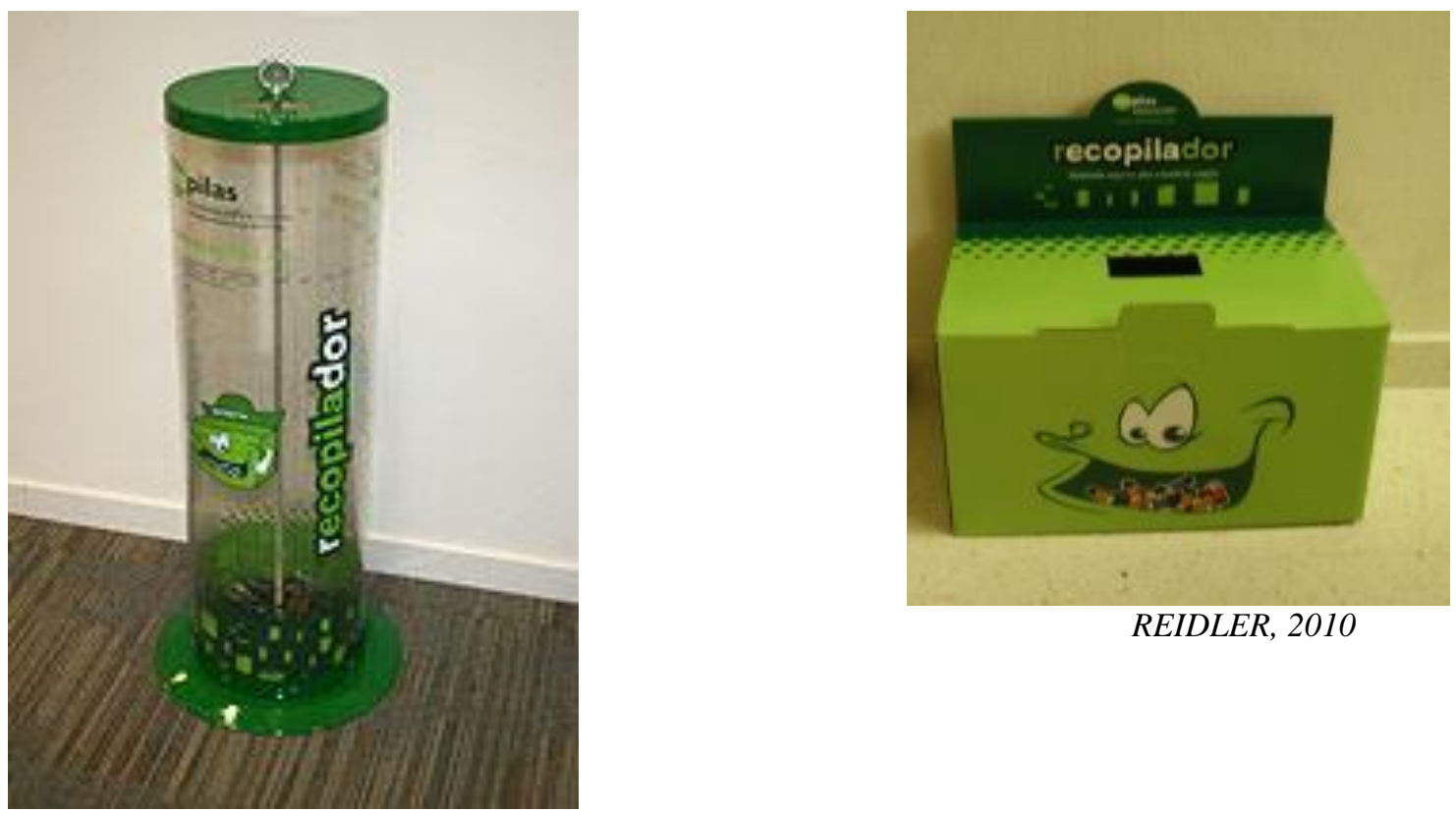

Figura 48 - Dois tipos de coletores de lâmpadas fornecidos a grandes usuários
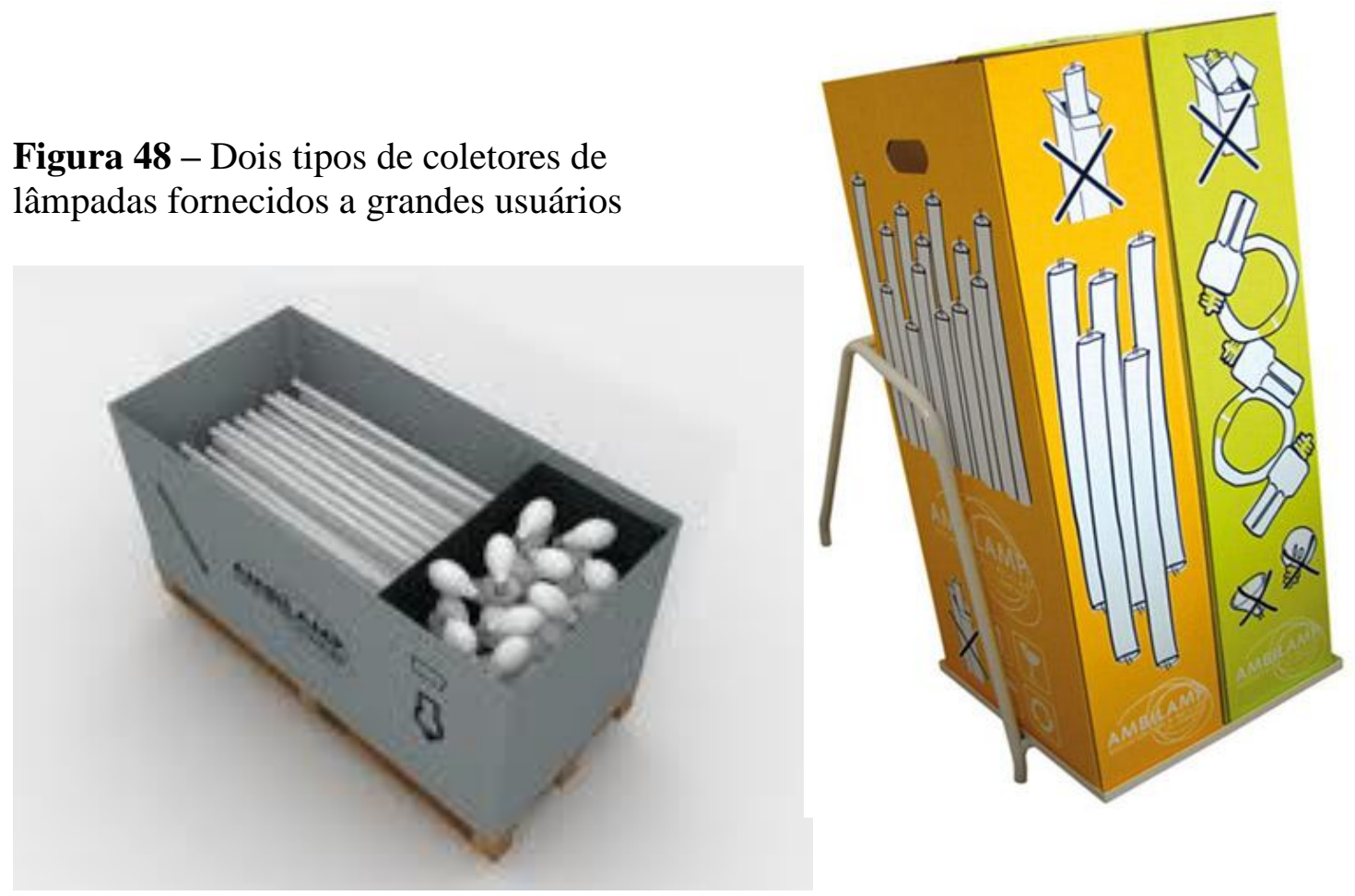
Figura 49 - Coletor de celulares para uso institucional e comercial

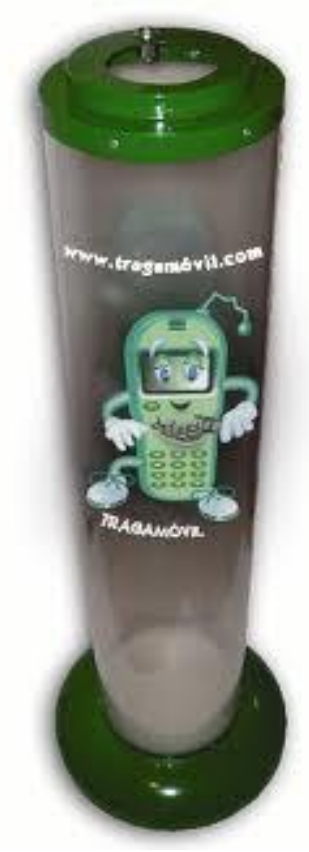

TRAGAMOVIL, 2010
Figura 50 - Coletor de pequenos REEE

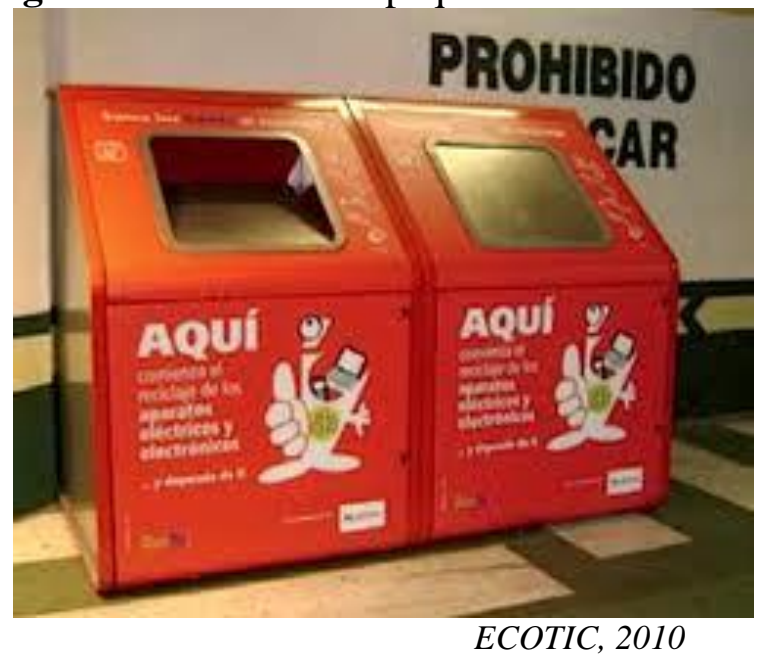

\subsection{COMPARACÃO ENTRE A GESTÃO DE REEE NA ESPANHA E NO BRASIL}

As visitas técnicas e os contatos com os SIG revelaram que alguns deles, como a AMBLILAMP, são bem organizados e economicamente autossustentáveis. Segundo as informações obtidas, um dos motivos dessa sustentabilidade deve-se ao fato de que apenas um SIG atua na gestão de lâmpadas em todo o território nacional. Os outros SIG de REEE competem entre si por mais adesões.Alguns produtores são associados a mais de um SIG de REEE e há mais de um SIG de REEE para categoria. Um dos objetivos da Cátedra RELEC da UCA é oferecer um espaço democrático a todos os SIG de REEE da Espanha, para o debate de questões de interesse comum. Não se pode afirmar que tantos SIG competindo entre si pelas mesmas atividades sejam muito produtivos. Em vários países da UE há no máximo um SIG por categoria da WEEE. O Quadro 10 resume os principais SIG estabelecidos na Espanha e respectivos campos de atuação. 
Quadro 10 - Resumo dos principais SIG em funcionamento na Espanha

\begin{tabular}{|l|c|l|}
\hline SIG & Categorias de REEE & Pontos de Coleta \\
\hline AMBILAMP & 5 & $\begin{array}{l}\text { Distribuidores, Puntos Limpios e Grandes } \\
\text { Usuários }\end{array}$ \\
\hline ECOASIMELEC & $1,2,3,4,6,7,8,9$ & Distribuidores e Puntos limpios \\
\hline ECOFIMATICA* & 3 & Distribuidores \\
\hline ECOLEC & $1,2,3,4,6,8,9,10$ & $\begin{array}{l}\text { Puntos Limpios, Distribuidores e } \\
\text { Domiciliares }\end{array}$ \\
\hline ECOLUM & 5 & $\begin{array}{l}\text { Distribuidores, Puntos Limpios e Grandes } \\
\text { Usuários }\end{array}$ \\
\hline ECO-RAEEs & $1,2,3,4,5,6,7,8,9,10$ & Distribuidores e Puntos Limpios \\
\hline ECOTIC & $\begin{array}{r}1,2,3,4,5,6,7,8,9,10 \text { (só } \\
\text { de uso profissional) }\end{array}$ & Distribuidores e Puntos Limpios \\
\hline ERP & $1,2,3,4,6,7,8,9,10$ & Distribuidores e Puntos Limpios \\
\hline TRAGAMOVIL* & 3 & Distribuidores e Puntos limpios \\
\hline ECOPILAS & Pilhas e baterias & Distribuidores, varejo, etc. \\
\hline
\end{tabular}

*Sistemas Unificados REIDLER, 2011

No Brasil, os produtores não cogitam a possibilidade de se associar para constituir sistemas integrados de gestão. É mais comum que se reúnam quando há necessidade de discutir questões de ordem legal ou tributária, por exemplo. A gestão de REEE, quando existe, é realizada de maneira individualizada e, as operações de logística reversa e reciclagem não são claras. Há luzes e sombras que deformam a realidade e impedem que se obtenha um panorama real da situação. As empresas de reciclagem estabelecidas no país fornecem informações quando solicitadas, mas raramente permitem que se visitem as suas plantas, como ocorre na Europa. Espera-se que, com uma legislação sobre REEE consolidada, implementada e fiscalizada, o país dê mais um passo para o desenvolvimento nesse sentido. Com a organização de produtores em SIG de REEE, o custo da gestão poderia diminuir consideravelmente, em função do ganho da economia de escala, como acontece com as mesmas empresas produtoras de REEE na Europa, na América do Norte e no resto do mundo. Em fase de elaboração, a legislação brasileira deveria aprender com a experiência da União Europeia sobre o que não fazer e, utilizar como ponto de partida, a revisão das Diretivas WEEE e RoHS para orientar sua regulamentação. As revisões das Diretivas tentam corrigir as distorções e erros de interpretação que aqui tem servido de exemplos a serem copiados. 
O Quadro 11 resume as principais diferenças encontradas na gestão de REEE nas duas IES estudadas.

Quadro 11 - Gestão de REEE USP X UCA

\begin{tabular}{|c|c|c|}
\hline $\begin{array}{l}\text { GESTÃO DE REEE } \\
\text { PATRIMONIADOS }\end{array}$ & USP & UCA \\
\hline Gestão interna & $\begin{array}{l}\text { De maneira independente } \\
\text { em cada unidade. }\end{array}$ & $\begin{array}{l}\text { Gestão integrada, com logística } \\
\text { reversa. Responsabilidade do } \\
\text { Serviço de Prevenção da UCA }\end{array}$ \\
\hline Armazenamento & $\begin{array}{l}\text { Falta de espaço físico em } \\
\text { todas as unidades. }\end{array}$ & $\begin{array}{l}\text { Centro de Transferência de } \\
\text { Resíduos único. }\end{array}$ \\
\hline Coleta Seletiva & $\begin{array}{l}\text { Coletor de pilhas em uma } \\
\text { unidade. }\end{array}$ & $\begin{array}{l}\text { Coletores de pilhas, lâmpadas e } \\
\text { tubos fluorescentes, celulares, }\end{array}$ \\
\hline Coleta seletiva & $\begin{array}{l}\text { Coleta de tubos } \\
\text { fluorescentes (individual). }\end{array}$ & $\begin{array}{l}\text { pequenos EEE e jaulas para } \\
\text { separação de grandes REEE. } \\
\text { em categorias operacionais. }\end{array}$ \\
\hline Gestão externa & Não há. & $\begin{array}{l}\text { Gestores externos contratados } \\
\text { (SIGs de REEE). }\end{array}$ \\
\hline Destino & $\begin{array}{l}\text { Doação de acordo com o } \\
\text { estabelecido no Manual } \\
\text { de Administração } \\
\text { Patrimonial. }\end{array}$ & $\begin{array}{l}\text { Gestores finais contratados para a } \\
\text { logística reversa, tratamento e } \\
\text { disposição final. }\end{array}$ \\
\hline
\end{tabular}

A partir do diagnóstico foram identificados pontos favoráveis e fracos nas duas IES estudadas, para auxiliar na elaboração de seus planos de gestão de REEE. Observou-se que ambas possuem credibilidade internacional como instituições de pesquisa e contam com um capital humano valioso, composto de especialistas em todas as áreas do conhecimento necessárias para implementação de um sistema de gestão de REEE de alta qualidade, mas nenhuma delas faz uso dessa vantagem.

A USP conta com um programa de reciclagem, o USP Recicla, desde 1994. Porém, suas ações se resumem basicamente à coleta seletiva de recicláveis comuns, tais como papel, plástico, metal e vidro. Recentemente iniciou a coleta de pilhas, baterias e cartuchos de impressoras, para encaminhamento à reciclagem. O programa poderia ser reestruturado para conduzir a gestão de REEE da USP, em parceria com o CEDIR, um centro idealizado para a reutilização ou desmontagem e destinação de REEE de informática e telecomunicações da USP. Apesar de ser um projeto elaborado de acordo com as necessidades básicas para um gerenciamento interno de REEE da USP, o CEDIR funciona apenas parcialmente, em função da falta de planejamento e de pessoal para operar o sistema. 
A UCA conta com a Cátedra RELEC, referência nacional e internacional para o setor de REEE. Porém, dentro da instituição, enfrenta dificuldades para operar a gestão de REEE, em função da cultura institucional que, ao não valorizar o trabalho em equipe, favorece a competição entre os setores. A falta de integração é um ponto negativo comum a ambas as IES e resulta em duplicidades trabalhos, lacunas de responsabilidades, falhas no sistema de gestão, desperdícios e custos desnecessários, coforme se pode observar, por exemplo, entre a OFICINA VERDE, o Serviço de Prevenção e a Cátedra RELEC da UCA.

A influência da legislação específica sobre a gestão de REEE e a existência de infraestrutura interna e externa são pontos positivos para um bom desempenho de um sistema de gestão de REEE na UCA. A USP não conta com tais facilidades, mas a implementação de um sistema de gestão integrada no QS/D pode ser favorecida pela a proximidade geográfica de suas unidades, com integração dos setores e da logística reversa dos REEE.

Outro ponto importante observado foi a falta de monitoramento dos fluxos externos de REEE não patrimoniados na UCA e de todos os REEE na USP. A falta de controle sobre os EEE/REEE de consumo é um problema comum a ambas as instituições e que carece de solução urgente e pode ser resolvido com o registro de todo o material que entra na IES e do controle do que é encaminhado para reciclagem ou tratamento. Um ponto positivo importante para a USP é a oportunidade de aprender com as falhas observadas na UCA e implementar um sistema de gestão mais eficiente. Elaborar um sistema novo de maneira correta pode ser um processo menos complexo do que corrigir falhas já institucionalizadas.

No Quadro 12 são comparados os principais pontos favoráveis e pontos fracos identificados nas duas IES estudadas, para a elaboração de um plano de gestão integrada de REEE. 
Quadro 12: Comparativo entre os pontos fortes e os pontos fracos da USP e da UCA

\begin{tabular}{|c|c|c|}
\hline IES & Campus QS/D - USP & UCA \\
\hline Pontos fortes & $\begin{array}{ll}\text { - } & \text { Credibilidade } \\
\text { - } & \text { Poder de negociação } \\
\text { - } & \text { Capital humano } \\
\text { - } & \text { Geografia } \\
\text { - } & \text { CEDIR } \\
\text { - } & \text { USP-RECICLA }\end{array}$ & $\begin{array}{ll}\text { - } & \text { Credibilidade } \\
\text { - } & \text { Cátedra RELEC } \\
\text { - } & \text { Capital humano } \\
\text { - } & \text { Infraestrutura } \\
\text { - } & \text { Legislação } \\
\text { - } & \text { SIG de REEE em nível } \\
& \text { nacional } \\
\text { - } & \text { OFICINA VERDE }\end{array}$ \\
\hline Pontos fracos & $\begin{array}{l}\text { - Falta de integração entre os setores } \\
\text { - Falta de controle sobre REEE não } \\
\text { patrimoniados e monitoramento dos } \\
\text { fluxos } \\
\text { - Falta de capacitação profissional } \\
\text { - Falta de infraestrutura } \\
\text { - Falta de comunicação } \\
\text { - Falta de padronização de } \\
\text { procedimentos }\end{array}$ & $\begin{array}{l}\text { - } \text { Falta de integração entre } \\
\text { os setores } \\
\text { - } \text { Falta de controle sobre } \\
\text { REEE não patrimoniados e } \\
\text { monitoramento dos fluxos } \\
\text { - Baixa eficiência do sistema } \\
\text { de gestão interna de } \\
\text { resíduos } \\
\text { - } \text { Cultura institucional } \\
\text { - } \text { Falha de comunicação } \\
\text { Geografia }\end{array}$ \\
\hline
\end{tabular}

\subsubsection{Fluxos de REEE identificados no Brasil e na Espanha}

O estudo mostrou que, em ambas as IES estudadas, existem distintos fluxos de REEE, dependendo de seu status dentro da instituição, conforme mostra o Quadro 13. 
Quadro 13 - Comparativo entre os fluxos de REEE gerados na USP e na UCA

\begin{tabular}{|c|c|c|}
\hline STATUS & FLUXO REEE USP & FLUXO REEE UCA \\
\hline EEE patrimoniados & $\begin{array}{ll}\text { - } & \text { BENS INSERVIVEIS } \\
\text { - } & \text { Doação } \\
\text { - } & \text { Segregação } \\
\text { - } & \text { Reutilização } \\
\text { - } & \text { Desmontagem } \\
\text { - } & \text { Venda } \\
\text { - } & \text { Sucateiros } \\
\text { - } & \text { LIXO COClagem } \\
\end{array}$ & $\begin{array}{ll}\text { - } & \text { BENS BAIXADOS } \\
\text { - } & \text { Coleta seletiva } \\
\text { - } & \text { Armazenamento } \\
& \text { temporário } \\
\text { - } & \text { SIG } \\
\text { - } & \text { Logística reversa } \\
\text { - } & \text { Reciclagem } \\
\text { - } & \text { Disposição final de rejeito }\end{array}$ \\
\hline $\begin{array}{l}\text { EEE não patrimoniados e } \\
\text { EEE de consumo }\end{array}$ & $\begin{array}{ll}\text { - } & \text { SUCATA } \\
\text { - } & \text { LIXO COMUM } \\
\text { - } & \text { USP Recicla } \\
\text { - } & \text { Catadodores } \\
\text { - } & \text { Venda } \\
\text { - } & \text { Sucateiros } \\
\text { - } & \text { Reciclagem } \\
\text { LIXO COMUM }\end{array}$ & $\begin{array}{ll}\text { - } & \text { SUCATA } \\
\text { - } & \text { LIXO COMUM } \\
\text { - } & \text { Oficina Verde } \\
\text { - } & \text { Reciclagem } \\
\text { - } & \text { Sucateiros } \\
\text { - } & \text { LIXO COMUM }\end{array}$ \\
\hline $\begin{array}{l}\text { EEE de empréstimo ou } \\
\text { comodato } \\
\text { (não patrimoniado) }\end{array}$ & $\begin{array}{ll}\text { - } & \text { DEVOLUÇÃO } \\
\text { - } & \text { Doação } \\
\text { - } & \text { FUSSESP } \\
\text { - } & \text { Leilão } \\
\text { - } & \text { Reciclagem } \\
\text { - } & \text { LIXO COMUM }\end{array}$ & $\begin{array}{ll}\text { - } & \text { DEVOLUÇÃO } \\
\text { - } & \text { Reciclagem } \\
\text { - } & \text { Sucateiros } \\
\text { - } & \text { LIXO COMUM }\end{array}$ \\
\hline
\end{tabular}

Observa-se que, apesar de diferentes, que todos os fluxos geram rejeitos e parte desses REEE termina no lixo comum. 


\section{DIRETRIZES PARA A GESTAO INTEGRADA DE REEE EM INSTITUIÇÕES DE ENSINO SUPERIOR}

As diretrizes aqui propostas têm o objetivo de orientar o desenvolvimento de um sistema de gestão integrada de REEE em IES, coerente e adequado a cada caso, em conformidade com os requisitos legais aplicáveis e segundo as diferentes realidades. Estas diretrizes são de aplicação geral e podem ser utilizadas na elaboração de planos de gestão integrada de REEE em instituições de qualquer porte ou tipo.

\subsection{PLANO DE GESTÃO DE REEE EM IES}

$\mathrm{Na}$ hierarquia da estrutura organizacional, um plano de gestão de REEE (PGREEE) se situa como uma ramificação do plano de resíduos, dentro do Sistema de Gestão Ambiental da instituição e deve ser alinhado com a política de resíduos estabelecida na IES. Na falta de tal estrutura, pode ser elaborado de forma individual e deve ser flexível para se adaptar às tendências de constantes mudanças tecnológicas que vem ocorrendo no setor de EEE, às políticas, leis, normas e eventuais planos de gestão que venham a surgir. O plano deve obter a aprovação e o comprometimento da diretoria, antes de ser implantado e seu principal público-alvo se concentra na administração da instituição e os gestores competentes para sua preparação.

O papel da Diretoria é fundamental para o êxito do plano de gestão integrada de REEE. A ela compete promover as mudanças estruturais e de cultura institucional, demonstrando empenho em garantir a transparência e a ética. A análise de riscos inerentes aos procedimentos incorretos na gestão do REEE deve nortear a revisão de práticas adotadas na institução no caminho da sustentabilidade. A valorização de idéias e iniciativas para a melhoria da gestão integrada, com o reconhecimento do esforço dos responsáveis por melhorias na gestão, é a base de sustentação de um plano de gestão integrada de EEE/REEE. É função da Diretoria estabelecer prioridades, objetivos e metas, em conjunto com os colaboradores. A Diretoria define responsabilidades e competências e cobra resultados. 
É fundamental considerar as diferentes atividades e operações em que as universidades estão envolvidas, como a pesquisa e a educação e o engajamento da gestão em formular políticas públicas. As IES possuem o capital humano para promover as mudanças necessárias, para que a prática de doação se torne um projeto social e passe a gerar impactos positivos. A doação pode se transformar em projeto social autosustentável, desde que associada à gestão externa do fluxo e destino dos REEE. Os custos de logística reversa podem ser neutralizados por meio de parcerias com organizações externas, para capacitação de mão de obra especializada nas diferentes operações de gerenciamento desses resíduos. Essas ações coordenadas podem gerar maiores oportunidades de emprego, renda mais justa e melhor qualidade de vida e saude do trabalhador e sua família, além de minimizar os impactos ambientais decorrentes dos fluxos de REEE.

Um plano de gestão integrada de REEE (PGREEE) em IES tem a função de formalizar ideias, além de servir como roteiro para o planejamento de um sistema de gestão eficiente e sustentável para esses resíduos na instituição e deve conter uma revisão das políticas gerais de e princípios de aplicação ao planejamento em seu campo de atuação e incluir uma revisão da legislação em vigor. O plano é a base da ação, do controle e das medidas paliativas, quando as circunstâncias assim o exigem. Um sumário executivo, contendo as principais diretrizes da linha de gestão a ser adotada deve ser divulgado a toda a comunidade envolvida, incluindo docentes, funcionários, colaboradores e alunos. É importante empregar um sistema de fácil compreensão e utilização pelo usuário, que prontamente se preste a esse propósito. Os elementos fundamentais do PGIREEE em IES são:

- Organização de ideias

- Horizonte temporal

- Flexibilidade das etapas

- Diagnóstico

- Objetivos e metas

- Infraestrutura

- Aquisição de bens e serviços

- Cronograma, definição de competências e responsabilidades

- Comunicação - Divulgação do Plano

- Implementação e monitoramento 


\subsection{INTEGRANDO O PROCESSO DE GESTÃO DE REEE EM IES}

Planejar é essencialmente um processo sistemático que envolve a integração de uma variedade de atividades, recursos e intervalos de tempo. O planejamento se inicia com base no diagnóstico da situação atual dos REEE na instituição. A experiência mostrou que a promoção de workshops ou de reuniões com os setores envolvidos nas diferentes etapas da gestão de REEE, para apresentação do diagnóstico, é de grande valia para auxiliar na elaboração de diretrizes para um sistema de gestão integrada eficiente de REEE em IES. É importante que os responsáveis pelo bom desempenho do sistema se sintam parte do processo e que possam participar do debate, contribuindo com suas experiências e relatos de dificuldades enfrentadas na prática. A priorização do trabalho em equipe sobre o individual resulta em um enriquecimento da qualidade das informações e sugestões obtidas, para a elaboração das diretrizes.

Não existe uma estratégia ou padrão rígido ou de como estruturar um plano de gestão REEE, ou uma ordem a ser seguida na implementação de suas etapas. No entanto, uma matriz com as diretrizes para o planejamento, com os principais elementos do plano, pode ser útil para estruturar o Plano de Gestão Integrada de REEE. A maior parte do planejamento detalhado é executada antes da implantação do plano, mas não termina com sua implementação, pois discrepâncias, novas situações, constantes modificações na composição dos REEE e evolução das tecnologias tornam o processo dinâmico. Geralmente, um plano de gestão de residuos é elaborado para um período mínimo de cinco anos. Porém, no caso de REEE, o plano de gestão integrada deve prever revisões anuais, para acompanhar a velocidade das mudanças nesse setor. A natureza desses resíduos requer a estreita integração entre planejamento para sua aquisição, processos de comumincação contínua, manutenção e controle durante sua vida útil, gerenciamento interno de REEE monitoramento dos fluxos e gestão externa, até seu destino final. A gestão de REEE em IES deve considerar a forte predominância de resíduos de TIC, os quais possuem uma vida útil cada vez menor.

Como resultado desta pesquisa e tomando-se como base o plano de gestão de resíduos já existente na instituição, propõe-se sua adaptação para incluir algumas ações e atividades específicas, fundamentais para a gestão integrada de REEE em IES. O sistema proposto deve abranger todas as etapas do ciclo de vida dos EEE, a partir do planejamento de sua aquisição, acompanhando o período de sua vida útil, antes que 
esses se tornem resíduos. Assim, pode-se dividir a gestão integrada dos EEE/REEE em três grandes etapas:

I) Antes de sua entrada na IES: Aquisição de bens e serviços

II) Durante a permanência na IES: gestão interna de EEE/REEE

III) Após a saída: gestão externa de REEE

Recomenda-se que seja formado um Comitê Gestor de REEE, composto por representantes dos principais setores envolvidos com a questão dos REEE na IES, tais como Diretoria, Administração, Compras, Patrimônio, Informática, Zeladoria, Corpo Docente, Corpo Discente, Setores de Saúde, Seguranca e Meio Ambiente, etc. Esse Comitê seria responsavel por fiscalizar, controlar e monitorar as ações e atividades, nas diferentes etapas do processo e o desempenho dos SGIREEE.

Uma gama valiosa de excelentes ferramentas de gestão está disponível no mercado, mas cada gestor deve eleger a que melhor se adapte às condições e realidades de sua instituição. Além disso, no caso de IES, sugere-se a utilização de seu sistema de informação gerencial como ponto de partida para integrar os setores e criar nova ferramenta, específica para a gestão de REEE. Entre as muitas possibilidades pode-se, por exemplo, integrar os sistemas de informação da Administração Patrimonial com os diferentes sistemas envolvidos, tais como os de Compras, Almoxarifado, Manutenção, Informática e outros.

Os Sistemas de Informação Patrimonial das IES estudadas, por exemplo, poderiam constituir excelentes ferramentas de gestão de integrada de EEE/REEE, se reformulados para inclusão de dados básicos tais como peso do material $(\mathrm{kg})$, datas de entrada e de saída (para cálculo da vida útil), destino (para monitoramento do fluxo), etc. Os dados e procedimentos de alimentação do sistema deveriam ser padronizados, para possibilitar estatísticas confiáveis para estimativa de dados fundamentais para a gestão de REEE. Um Sistema de Informação bem estruturado pode fornecer vários indicadores úteis para avaliação e controle do desempenho do sistema de gestão integrada de REEE na IES. Para garantir que todos os dados sejam informados, pode-se criar um sistema de informação que não permita a conclusão de um processo (de baixa, por exemplo), sem que todos os campos tenham sido preenchidos. É fundamental que se crie uma padronização de procedimentos e a se promova a capacitação profissional para 
operacao do sistema de informação. A seguir, alguns exemplos de indicadores úteis que podem ser extraídos do SIAP:

- Caracterização: \% REEE baixados por categoria operacional (logística reversa)

- Caracterização: \% REEE baixados por categoria WEEE da UE (logística reversa)

- Caracterização: \% de REEE por linha de cor (logística reversa)

- Estimativa de quantidade de geração: registro do peso $(\mathrm{kg})$ dos REEE gerados (controle e redução dos custos da gestão externa) (solicitar ao fornecedor a inclusão desse dado na fatura).

- Tempo de vida útil dos EEE: registro de datas de entrada e saída dos EEE

- Monitoramento do fluxo: registro destino dos REEE

- Controle da geração de REEE não patrimoniados: registro de EEE de consumo (não patrimoniados)

- Desempenho da manutenção: registro do motivo da baixa

- Qualidade do fornecedor: registro do motivo da baixa

Cabe salientar, que cada instituição pode criar novas diretrizes de acordo com suas próprias necessidades. Cada instituicao deverá definir seus proprios objetivos, metas e mecanismos de controle. O bom desempenho do sistema vai depender principalmente do trabalho do gestor da do esforço conjunto de todos os envolvidos. $\mathrm{Ou}$ seja, se obterbons resultados, vale investir na capacitação e na gestão de pessoas.

Durante o desenvolvimento do processo de implementação do PGIREEE, a instituição deverá definir as responsabilidades e competências do pessoal encarregado da gestão de REEE. Além disso, é preciso identificar as necessidades de formação e de capacitação relacionadas com os diferentes aspectos da gestão integrada de EEE/REEE. Para tanto, deve-se analisar se as pessoas necessitam de conhecimentos e experiências adicionais para desempenhar suas funções. Finalmente, a implementação na instituição deverá estabelecer os mecanismos de controle necessários para assegurar que todos os aspectos básicos da sustentabilidade (econômicos, sociais, ambientais e de saúde) relacionados com os REEE sejam geridos corretamente, minimizando os impactos negativos associados. A elaboração de um manual de procedimentos de gestão integrada de REEE e de protocolos de procedimentos para cada setor envolvido é fundamental para esta fase da gestão integrada dos EEE/REEE. 
A etapa de gestão interna dos EEE/REEE deve incluir:

- Sistema informação de REEE não patrimoniados

- Identificação de todos os EEE/REEE para garantir sua rastreabilidade

- Prevenção, Saúde e Segurança

- Ambiente e condições de trabalho

- Informação e Comunicação

- Capacitação operacional

- Indicadores e instrumentos de controle

- Ferramentas de gestão e monitoramento

- Gerenciamento de REEE respeitando a hierarquia de prevenção, reutilizacao, encaminhamento para a gestão externa (logística reversa).

Os projetos e programas, que fazem parte do planejamento na elaboração do plano de gestão, podem ser definidos de acordo com as seguintes prioridades. A seguir, alguns exemplos de projetos e programas que podem ser incluídos na gestão dos REEE:

- Projeto para adequação do Sistema de Informação da Administração Patrimonial para a gestão integrada dos REEE,

- Projeto para identificação de todos os EEE/REEE, para possibilitar a rastreabilidade

- Projeto para prolongamento da vida útil dos EEE,

- Projeto para reutilização de EEE dentro da própria instituição,

- Projeto para desmontagem de REEE,

- Programa de capacitação do pessoal envolvido com o gerenciamento de EEE/REEE

- Programa de minimização de REEE,

- Programa de segregação de REEE na origem,

- Programa de gestão de REEE perigosos,

- Programa de comunicação para informar e conscientizar todos os envolvidos com a questão dos REEE, incluindo os usuários e destinatários de doações,

- Programa de destruição de dados sigilosos,

- Programa de integração dos setores envolvidos na gestão dos REEE,

- Programa de gestão participativa com criação de Grupos de Trabalho dos diferentes setores, para a integração da gestão dos REEE das unidades. 
A etapa de gestão externa deve incluir:

- Logística reversa

- Rastreabilidade

- Monitoramento dos fluxos

- Garantia de disposição adequada

- Parcerias com outras instituições para reutilização de REEE Responsabilidade socioambiental

Antes da implementação do plano, as iniciativas para o seu monitoramento e revisão já deverão estar definidas. No início de um novo ciclo, após um novo diagnóstico de status, todos os pressupostos são reunidos e os resultados do plano anterior são avaliados e corrigidos com vistas à melhoria contínua. As questões de especial interesse incluem: a) que objetivos foram atingidos? b) que atividades planejadas não foram implementadas ou não produziram os resultados esperados? c) alguma iniciativa produziu impacto inesperado em outros setores? d) Quais os motivos desses resultados? e) o que pode ser melhorado?

No contexto do novo relatório de status e em função de qualquer nova política, novas normas e requisitos legais e novos objetivos, um novo plano deve ser preparado. A revisão e o monitoramento do plano não são detalhados nestas diretrizes, mas são fundamentais para sua sustentabilidade e para o processo de melhoria contínua.

No Quadro 14 resumem-se as diretrizes básicas propostas, com exemplos de ações, para a elaboração de um Sistema de Gestão Integrada de REEE (SGIREEE) em IES, que podem ser adapatadas a outros tipos de instituições. 


\section{Quadro 14: Diretrizes para a gestao integrada de EEE/REEE em IES}

ETAPA I: Aquisição de bens, serviços e materiais:

Planejamento: para aquisição de EEE, componentes e peças de reposição e material de consumo e servicos; integração das Compras das Unidades (quando possível), para ganhos de economia de escala; padronizacao de procedimentos.

Negociação do Setor de Compras com fornecedores: Integração das Compras das Unidades (quando possível), para aumentar o poder de negociação, na aquisicao de bens e serviços. Pode-se, por exemplo, exigir a garantia de que o fornecedor do EEE se encarregue da logística reversa dos EEE, ao final de sua vida útil. No caso de contratacao de gestores externos de REEE, pode-se exigir certificacao de disposição final adequada.

Mudança de comportamento: revisão da necessidade de aquisição e dos padrões de consumo. Conscientização do usuário, para evitar desperdícios.

Cadastro de compras atualizado: registro de todos os EEE, patrimoniados ou não; material de consumo; componentes e peças de reposição. Inclusão de dados: (ex) peso do material $(\mathrm{kg})$, data de entrada, data de saída, origem, tipo de material, responsável; identificação dos EEE; padronização de procedimentos.

ETAPA II: Gestão interna (vida útil dos EEE)

Usuário: cuidados com os EEE; evitar desperdícios de material de consumo e energia.

Administração Patrimonial e de Materiais: sistemas de informação integrados, com registros atualizados. Controle do almoxarifado. Inventários.

Manutenção: revisão periódica dos EEE; prolongamento da vida útil; teste de funcionamento para reutilização.

Reutilização: priorização da reutilização antes da logística reversa.

Padronização de procedimentos e capacitação dos envolvidos.

Gerenciamento interno de REEE: coleta seletiva; manejo correto; segregação por categoria de reciclagem; retirada de componentes perigosos; acondicionamento; armazenamento temporário; destinação.

Infraestrutura: disponibilização de espaço para armazenamento temporario e manejo de REEE, com condicoes adequadas de segurança e ambientais.

Segurança e saúde do trabalhador: informação sobre os riscos envolvidos, capacitação operacional, uso de EPIs, fiscalizacao e controle das condições de saude, ambiente e segurança.

Destinação: de maneira a garantir a minimização de impactos ambientais, sociais, de saúde e econômicos, decorrentes do fluxo dos REEE gerados na IES.

ETAPA III: Gestão externa (logistica reversa REEE)

Monitoramento dos fluxos: transporte; destinos; descontaminação; reciclagem; disposição final final de rejeitos; controle e minimização de impactos decorrentes do fluxo.

Certificação de tratamento e destino adequados; conformidade legal 


\section{CONCLUSÕES E RECOMENDAÇÕES}

As diferentes abordagens de gestão e gerenciamento de resíduos encontradas na literatura apontam para uma tendência de sistemas de gestão integrada que incluem aspectos fundamentais de sustentabilidade em todas as suas etapas. Esse novo modelo prioriza a hierarquia de prevenção e reutilização, antes de dar início ao processo de logística reversa e/ou tratamento ou disposição final ambientalmente adequada. Essa visão representa uma evolução do conceito de minimização de resíduos descrito por DOUGLAS (1988), o qual concentra seu foco na geração. Contudo, os resultados desta pesquisa indicam que, quando se trata de gestão de REEE em grandes organizações, essa visão contempla apenas parte do problema. Os impactos sociais, econômicos, ambientais e na saúde ocorre em todas as etapas do ciclo de vida dos EEE. Propõe-se um sistema de gestão integrada mais amplo, que abranja todas as etapas do ciclo de vida do EEE na instituição, desde o planejamento para sua aquisição, incluindo a gestão interna de EEE com o prolongamento de sua vida útil e promovendo sua reutilização, antes de considerar os processos de gerenciamento interno e de gestão externa dos REEE. Recomenda-se um sistema de gestão integrada de EEE/REEE.

Para o gerenciamento interno de REEE apropriado, além da padronização de procedimentos, recomenda-se disponibilizar uma área adequada para segregação, retirada de componentes perigosos, teste para reutilização, reparo, armazenamento temporário e pesagem de REEE. Esta etapa permite uma considerável redução dos custos da gestão externa, que é cobrada em função do peso $(\mathrm{kg})$, do tipo de material e de sua periculosidade. A gestão de REEE perigosos envolve custos muito mais altos do que a de materiais recicláveis. Recomenda-se também um maior envolvimento dos Programas de Educação Ambiental como o USP Recicla (UCA) e a Oficina Verde (UCA), para a da capacitação profissional dos operadores do sistema.

Identificou-se a existência de diferentes fluxos de REEE em uma mesma instituição, dependendo do status do EEE durante sua vida útil. Se o material for patrimoniado, é possível conhecer sua destinação, mas não existe monitoramento de seu fluxo, nem conhecimento de seu destino final. Se não for patrimoniado, não há registros sobre quantidades ou destinos e é impossível monitorar seu fluxo. Seria ideal que se 
criasse um sistema de informação específico para REEE, com a integração de sistemas de informação de todos os setores envolvidos com a questão dos REEE e a inclusão de dados básicos para sua gestão e monitoramento de fluxo. Recomenda-se que se mantenha um registro atualizado de todos os EEE, patrimoniados ou não, para que se possa efetuar uma gestão correta e responsável de REEE. Caracterizar as práticas atuais de disposição de REEE é um passo fundamental no desenvolvimento de políticas que previnam impactos ambientais, sociais e de saúde, maximizando o potencial de benefícios sociais e econômicos da reutilização. A Cátedra RELEC da UCA estuda um meio de rastrear os REEE gerados na instituição e propõe a identificação por radio frequência. Como alternativa, com base na importância da rastreabilidade de todos os tipos de REEE, recomenda-se um sistema de leitura de código de barras, que poderia identificar todos os itens, patrimoniados ou não. Outro projeto desenvolvido pela Cátedra RELEC é para promover a reutilização de EEE dentro da própria IES.

Os resultados da pesquisa na UCA mostraram que o desempenho do sistema de gestão integrada de REEE é diretamente influenciado por motivos instrumentais e motivos de ordem político-administrativa, os quais têm efeitos indiretos sobre o desempenho ambiental através da responsabilidade ambiental da instituição. Conclui-se que a existência de legislação específica sobre o tema exerce forte influência na gestão de REEE, mas não garante totalmente o bom desempenho do sistema. Nesse caso, também existem diferentes fluxos para diferentes origens dos REEE. A estrutura organizada de logística reversa, reciclagem, tratamento e disposição final oferecida por Sistemas Integrados de Gestão de REEE autorizados para esse fim é fundamental para o bom funcionamento do sistema de gestão integrada de REEE. Porém, o fluxo dos EEE não registrados no sistema segue caminhos duvidosos. Recomenda-se a integração dos setores e que a coordenação dos fluxos físicos seja adaptada aos padrões de coleta.

Ao se estudar o caso da USP, uma das mais importantes universidades da América Latina, constatou-se que embora exista na IES a preocupação com questões ambientais, os procedimentos adotados não atendem aos requisitos fundamentais da sustentabilidade. Após o processo de baixa patrimonial, os EEE adquirem o status de bens inservíveis. Para efeitos administrativos, esses deixam de existir e geralmente são doados a instituições filantrópicas, sem fins lucrativos. Assim, nao há seguimento do fluxo de REEE gerados na instituição. Teoricamente, a doação seria uma solução 
sustentável, pois além de não se gerar REEE, contribui-se para programas sociais e elimina os custos de logística reversa e/ou tratamento e disposição final. Na prática, os resultados mostram que essa é uma maneira de transferir o problema sem efetivamente resolvê-lo. Mesmo que entre o material doado haja EEE reutilizáveis, esses são quase sempre equipamentos obsoletos e consequentemente, com previsão de curta sobrevida. Verificou-se que a maioria do material doado consiste em equipamentos avariados, muitas vezes irrecuperáveis. Entre esses encontram-se REEE perigosos, que necessitam ser tratados antes da disposição final, o que não ocorre na prática. Conclui-se que doação pode gerar impactos negativos sob todos aspectos fundamentais da sustentabilidades: sociais, econômicos, ambientais e de saúde. Recomenda-se fortemente que a prática da doação seja revista. As IES, como centros de formação e de conhecimento, têm o dever de adotar uma política de responsabilidade socioambiental e reverter essa situação. 


\section{REFERÊNCIAS}

ALVES-MAZZOTTI, A. J.; GEWANDSZNAJDER, F. O método nas ciências naturais e sociais. 2. ed. São Paulo: Pioneira Thompson Learning, 2001.

ANATEL. Estatísticas de Celulares no Brasil, março de 2012. Disponível em: <http://www.teleco.com.br/ncel.asp>. Acesso em 10 de abr. 2012

ANDRADE, M. M. de. Introdução à metodologia do trabalho científico. 6. ed. São Paulo: Atlas, 2003

AGENDA 21. O princípio da Precaução. Princípio 15 da Declaração do Rio sobre Meio Ambiente e Desenvolvimento. Agenda 21: The Earth summit strategy to save our planet. June 13, 1992 in Rio de Janeiro, Brazil. Disponível em: $<$ http://www.osti.gov/energycitations/product.biblio.jsp?osti_id=6289330>. Acesso em 15 jan.2011.

ARAUJO, M. G. et al. A model for estimation of potential generation of waste electrical and electronic equipment in Brazil. Waste Management. Volume 32, Issue 2, February 2012, Pages 335-342

BABBITT, C. W.; Kahhat R.; Williams, E; Babbitt, G.A.; Evolution of Product Lifespan and Implications for Environmental Assessment and Management: A Case Study of Personal Computers in Higher Education. Environment Science and Technology, 2009, 43 (13), pp 5106-5112.

BELLIS, M. The History of the Integrated Circuit aka Microchip. 2011. About.com (A part of The New York Times Company). All rights reserved. Disponível em: $<$ http://inventors.about.com/od/istartinventions/a/intergrated_circuit.htm>. Acesso em 29 out. 2011

BIS. Department for Business Innovation \& Skills. - Study No. 07010401/2006/442493/ETU/G4. Differentiated targets for collection, recycling and treatment. Disponível em: 
<http://ec.europa.eu/environment/waste/weee/pdf/rpa_study.pdf2006>. Acesso em 12 Nov. 2010

BOICE JR, J.D.; TARONE, R.E. Cell Phones, Cancer, and Children. Oxford Journals. JNCI - Journal of National Cancer Institute Oxford, 2011. n. 103(16): p.1205-1206 doi:10.1093/jnci/djr317

BOLETIN RELEC 12, de julio 2011. Publicación de la directiva RoHS revisada. Universidad de Cádiz - Círculos de Innovación y tecnología. Disponível em: $<$ http://www.relec.es/relec/noticias-archivadas/9-legislacion/695-publicacion-de-ladirectiva-rohs-revisada.html>. Acesso em 14 ago. 2011

BRASIL. Lei $\mathrm{n}^{\circ}$ 12.305, de outubro de 2010. Institui a Política Nacional de Resíduos Sólidos; altera a Lei $\mathrm{n}^{0}$ 9.605, de 12 de fevereiro de 1998; e dá outras providências. Diário Oficial da União, Brasília, DF, 3 ago. 2010.

BRASIL. Lei Federal Nº 6.938, DE 31 DE AGOSTO DE 1981.Dispõe sobre a Política Nacional do Meio Ambiente, seus fins e mecanismos de formulação e aplicação, e dá outras providências. Art.14. $\S 1^{\circ}$. Disponível em:

<http://www.bvambientebf.uerj.br/arquivos/edu_ambiental/popups/lei_federal.htm>. Acesso em 14 jan. 2012.

BRASIL. Lei 9.605/1998 (Lei Ordinária) 12/02/1998. Ementa: Dispõe sobre as sanções penais e administrativas derivadas de condutas e atividades lesivas ao meio ambiente e dá outras providências. Origem:LEGISLATIVO. Diário Oficial da União. Brasília, DF 13/02/1998, P. 1.

CCE - Centro de Computação Eletrônica - Lixo eletrônico da USP agora poder ter um destino sustentável. Disponível em: http://www.cce.usp.br/?q=node/266. Acesso em 16 ago. 2010.

CE - Comissão Europeia. Decisão 2000/532/CE, da Comissão Europeia, de 3 de maio de 2000, modificada pelas Decisões 2001/118/CE, de 16 de janeiro de 2001 e 2001/119, de 22 de janeiro, da Comissão Europeia e, pela Decisão 2001/573, de 23 de julho, do Conselho Europeu, publicam-se as operações de valorização e de eliminação de resíduos e, a Lista Europeia de Resíduos (LER), que funde em uma única lista os 
resíduos perigosos e não perigosos. Disponível em: < http://eurlex.europa.eu/LexUriServ/LexUriServ.do?uri=OJ:L:2000:226:0003:0003:PT:PDF>. Acesso em: 12 jan. 2011.

CE - Comissão Europeia. Directiva 2006/66/CE do Parlamento Europeu e do Conselho da União Europeia, de 6 de Setembro de 2006, relativa a pilhas e acumuladores e respectivos resíduos e que revoga a Directiva 91/157/CEE (Texto relevante para efeitos do EEE). Bruxelas, 2006. Jornal Oficial das Comunidades Europeias JO L 266 de 26/09/2006, p. 114. Versão PT. 2006 b.

CE, Directiva 2008/98/CE del Parlamento Europeo y del Consejo, de 19 de noviembre de 2008, sobre los residuos y por la que se derogan determinadas Directivas (Texto pertinente a efectos del EEE). Disponível em: <http://eurlex.europa.eu/LexUriServ/LexUriServ.do?uri=OJ:L:2008:312:0003:0030:ES:PDF>. Acesso em: 12 Jan. 2012

CE - Comissão Europeia. Directiva 91/156/ CEE, del Consejo, de 18 de marzo de 1991, por la que se modifica la Directiva 75/442/CEEE relativa a los resíduos. Diário Oficial $\mathrm{N}^{\circ} \mathrm{L} 078$ de 26/03/1991 p. 0032 - 0037.

CE - Comissão Europeia. Directiva 91/157/CEE do Conselho, de 18 de Março de 1991, relativa às pilhas e acumuladores contendo determinadas matérias perigosas. Jornal Oficial $n^{\circ}$ L 078 de 26/03/1991 p. 0038 - 0041

CE - Comissão Europeia. Directiva 91/689/CEE do Conselho, de 12 de Dezembro de 1991, relativa aos resíduos perigosos. A presente directiva, elaborada por força do $\mathrm{n}^{\circ} 2$ do artigo 2o da Directiva 75/442/CEE, tem por objetivo a aproximação das legislações dos Estados-membros sobre a gestão controlada dos resíduos perigosos. A referida lista incluídos REEE no Código “16.02: Resíduos de Equipamentos Elétricos e Eletrônicos. Jornal Oficial no L 377 de 31/12/1991 p. 0020 - 0027

CE - Comissão Europeia. Decisión de La Comisión, de 5 de agosto de 2009, por la que se establecen requisitos para el registro de productores de pilas y acumuladores, de conformidad con la Directiva 2006/66/CE del Parlamento Europeo y del Consejo [notificada con el número C (2009) 6054] (Texto pertinente a efectos del EEE). 
(2009/603/CE). Disponível em: <http://eur-

lex.europa.eu/LexUriServ/LexUriServ.do?uri=OJ:L:2009:206:0013:0015:ES:PDF>. Acesso em 13 out. 2011

CE - Comissão Europeia. Directiva 2008/103/CE do Parlamento Europeu e do Conselho, de 19 de Novembro de 2008, que altera a Directiva 2006/66/CE relativa a pilhas e acumuladores e respectivos resíduos no que respeita à colocação de pilhas e acumuladores no mercado (Texto relevante para efeitos do EEE).

CE, Directiva 75/422/CEE - Lei sobre resíduos, do Conselho, de 15 de julho de 1975, relativa aos resíduos. Dispõe sobre regulamentações específicas para categorias particulares de resíduos. Disponível em: <http://eurlex.europa.eu/LexUriServ/LexUriServ.do?uri=CELEX:51999DC0752:PT:HTML>. Acesso em 15 ago. 2011.

CE, Directiva 91/689/CEE do Conselho, de 12 de Dezembro de 1991, relativa aos resíduos perigosos. Lista Europeia de Residuos. Os REEE estão incluídos no Código “16.02: Resíduos de Equipamentos Elétricos e Eletrônicos.

Jornal Oficial das Comunidades Europeias $n^{\circ}$ L 377 de 31/12/1991 p. 0020 - 0027

CE. Decisión de La Comisión, de 5 de agosto de 2009, por la que se establecen requisitos para el registro de productores de pilas y acumuladores, de conformidad: con la Directiva 2006/66/CE del Parlamento Europeo y del Consejo [notificada con el número C (2009) 6054] (Texto pertinente a efectos del EEE). (2009/603/CE).

Disponível em: http://eurlex.europa.eu/LexUriServ/LexUriServ.do?uri=OJ:L:2009:206:0013:0015:ES:PDF. Acesso em 13 out. 2011.

CE. Directiva 2008/103/CE do Parlamento Europeu e do Conselho, de 19 de Novembro de 2008, que altera a Directiva 2006/66/CE relativa a pilhas e acumuladores e respectivos resíduos no que respeita à colocação de pilhas e acumuladores no mercado (Texto relevante para efeitos do EEE). Disponível em: <http://eurlex.europa.eu/LexUriServ/LexUriServ.do?uri=OJ:L:2008:327:0007:0008:PT:PDF>. Acesso em: 12 Jan. 2012 
CERVO, Amando Luiz; BERVIAN, Pedro Alcino. Metodologia científica. São Paulo: Makron Books, 1996.

CHEN, Y-S; CHANG-C-H; WU, F-S Origins of green innovations: the differences between proactive and reactive green innovations, Management Decision, 2012: Vol. 50 Iss: 3

CNUMAD, 1997. Conferência das Nações Unidas sobre Meio Ambiente e Desenvolvimento. Agenda 21, Senado Federal, Subsecretaria de Edições Técnicas, $2^{\text {a }}$ ed., Brasília, 598 p.

COMISIÓN EUROPEA, Comunicación de la Comisión AL Parlamento Europeu con arreglo al artículo 294, apartado 6, del Tratado de Funcionamiento de la Unión Europea acerca de la posición del Consejo en relación con la adopción de una Directiva del Parlamento Europeo y del Consejo sobre residuos de aparatos eléctricos y electrónicos (RAEE) Bruselas, 11.8.2011. COM (2011) 478 final. 2008/0241 (COD) COUNCIL OF THE EUROPEAN UNION.Council revises rules on recycling of electronic devices. Brussels, 14 March 2011. 7632/11. PRESSE 58. Disponível em:

\section{COMPUTER HISTORY MUSEUM - Linha do Tempo dos Computadores Pessoais e}

Portáteis. Disponível em: http://retroplayerbrazil.wordpress.com/2011/02/05/linha-dotempo-dos-computadores-pessoais-tamanho-nao-e-documento/. Acesso 11 nov. 2010.

CONAMA. Resolução No 257, de 30 de junho de 1999. Correlações: - Revogada pela Resolução n 401/08 - Alterada pela Resolução n 263/99 (acrescentado inciso IV no art. 6o). A Resolução do Conselho Nacional do Meio Ambiente (CONAMA) sobre pilhas e baterias foi publicada no Diário Oficial da União (DOU), estando, portanto, em vigor a partir desta quarta-feira 05/11/2008. Disponível em: <http://www.mma.gov.br/port/conama/res/res99/res25799.html>. Acesso em: 02/07/2011.

CONSEJO DE LA UNIÓN EUROPEA, Bruselas, 7 de marzo de 2011 (11.03) (OR. en) Expediente interinstitucional: 2008/0241 (COD) 7042/11 LIMITE ENV 142 MI 98 CODEC 311 NOTA. CE, 2011. NOTA. De: Secretaría General A: Consejo. № doc. pre.: 6948/11 ENV 132MI 95 CODEC 298 + ADD 1. Nº proposición.: 17367/08 ENV 1022 MI 554 CODEC 1863 - COM (2008) 810 final. Asunto: Propuesta de Directiva 
del Parlamento Europeo y del Consejo sobre residuos de aparatos eléctricos y electrónicos (RAEE) - (Refundición) - Acuerdo político. Documento 17217/10.

Disponível em: 〈http://register.consilium.europa.eu/pdf/es/11/st07/st07042.es11.pdf〉. Acesso em: 12 ago. 2011.

CONSEJO DE UNIÓN EUROPEA. Propuesta de Directiva del Parlamento Europeo y del Consejo sobre residuos de aparatos eléctricos y electrónicos (RAEE) (Refundición). Bruselas, 7 de marzo de 2011 (11.03) (OR. en) Expediente interinstitucional: 2008/0241 (COD) 7042/11. Nota de la Secretaría General al Consejo. n. ${ }^{\circ}$ doc. pre.: 6948/11 ENV 132MI 95 CODEC 298 + ADD 1 n. ${ }^{\circ}$ proposición.: 17367/08 ENV 1022 MI 554 CODEC 1863 - COM (2008) 810 final. Acuerdo político. Disponível em: 〈http://register.consilium.europa.eu/pdf/es/11/st07/st07042.es11.pdf〉. Acesso em: 07 out. 2011.

COUNCIL OF THE EUROPEAN UNION - Acordo de revisão da Diretiva WEEE. Brussels, 14 March 2011 7632/11. PRESSE 58. Council revises rules on recycling of electronic devices. Disponível em:

<http://www.interempresas.net/Reciclaje/Articulos/49643-Los-ministros-europeosaprueban-por-unanimidad-un-acuerdo-sobre-la-Directiva-de-Raee.htm>. Acesso em: 15 Nov. 2011.

COUNCIL OF THE EUROPEAN UNION on waste electrical and electronic equipment (WEEE) (Recast) Interinstitucional. File: 2008/0241 (COD) - 17345/09 ADD 1 -ENV 880 MI 462 CODEC 1434. Proposal for a DIRECTIVE OF THE EUROPEAN PARLIAMENT AND OF THE COUNCIL on waste electrical and electronic equipment (WEEE) (Recast). Disponível em: <http://eurlex.europa.eu/LexUriServ/LexUriServ.do?uri=CELEX:52008PC0810:EN:NOT>. Acesso em: 11 Nov. 2011.

CRN - Center for Responsible Nanotechnology @ (2002-2008. What is nanotechnology? The Business of Nanotech by Stephen Baker and Adam Aston. Business Week. Feb 14, 2005. Disponível em: 〈http://www.crnano.org/index.html>. Acesso em 2 dec. 2011. 
DIAS, A.P. Soluções para o lixo tecnológico. Disponível em:

<http://www.cdisc.org.br/2008/03/27/santa-catarina-debate-solucoes-para-o-lixotecnologico/>. Acesso em 14 dec. 2011.

DOUGLAS, J. M. Conceptual Design of Chemical Processes; Mc Graw Hill: New York, 1988.

DURAO Jr, W. A. ; WINDMÖLLER, C.C. A questão do mercúrio em lâmpadas fluorescentes. Química Nova na Escola, n. 28. UNICAMP. Campinas, maio 2008.

ECOLEC - Exportación de RAEE: una actividad llena de oro y también de veneno Fundación ECOLEC, 2010. Estudo completo: Optimierung der Steuerung und Kontrolle grenzüberschreitender Stoffströme bei Elektroaltgeräten/Elektroschrott Disponível em: $<$ http://www.umweltbundesamt.de/uba-info medien/mysql_medien.php?anfrage=Kennummer\&Suchwort=3769>. Resumo em inglês disponível em:

$<$ http://www.umweltbundesamt.de/abfallwirtschaft/publikationen/transboundary_shipm ent_of_electronic_scrap_summary.pdf>. Acesso em 12 Mar 2012

ECO-RAEE. Se aprueba el acuerdo sobre la Directiva de Residuos de Aparatos Eléctricos y Electrónicos. Domingo, 24 de Julio de 2011. Disponível em: $<$ http://www.eco-raee.com/noticias-generales/noticias-2011/275-se-aprueba-el-acuerdosobre-la-directiva-de-residuos-de-aparatos-electricos-y-electronicos.html?lang>. Acesso em: 14 ago. 2011.

EEA - European Environment Agency: About Environment and Health. Disponível em: <http://www.eea.europa.eu/themes/human/about -environment-and-health/> > Acesso em: 12 nov. 2011.

EPA - Environment Protection Agency. Climate Change and Waste. Reducing Waste Can Make a Difference. Disponível em:

<http://www.epa.gov/epawaste/nonhaz/municipal/pubs/ghg/climfold.pdf.>. Acesso em: 13 out. 2010. 
EPA - Environment Protection Agency. Summary of the Resource Conservation and Recovery Act. HSWA: The Federal Hazardous and Solid Waste Amendments. U.S., 1984. Disponível em: <http://www.epa.gov/lawsregs/laws/rcra.html>. Acesso em: 9 Jan. 2012.

ESPANHA. RD 943/2010 - de 23 de julio, por el que se modifica el Real Decreto 106/2008, de 1 de febrero, sobre pilas y acumuladores y la gestión ambiental de sus residues. BOE. Boletin Oficial del Estado, Núm. 189, jueves 5 de agosto de 2010 Sec. I. Pág. 68187.

ESPANHA, Ministerio de la Presidencia - REAL DECRETO 106/2008, de 1 de febrero, sobre pilas y acumuladores y la gestión ambiental de sus resíduos. BOE num. 37 Martes 12 Feb. 2008. Disponível em: <http://www.boe.es/boe/dias/2008/02/12/pdfs/A07399-07410.pdf>. Acesso em: 2 nov. 2010.

ESPANHA, MINISTERIO DE LA PRESIDENCIA - Real Decreto 367/2010 (BOE n $^{\circ}$ 75/2010) sobre "sobre o livre acesso às atividades de serviços e seu exercício" modifica alguns artigos do RD 208/2005 de REEE. Boletín Oficial del Estado № 75/2010. $27 / 03 / 2010$

Disponível em: <http://www.derecho.com/legislacion/boe/27/03/2010>

ESPANHA - Real Decreto 208/2005, de 25 de fevereiro, sobre equipamentos elétricos e eletrônicos e a gestão de seus resíduos. Boletin Oficial do Estado n.47.

EUROLEX. Directiva 93/86/CEE da Comissão de 4 de Outubro de 1993 que adapta ao progresso técnico a Directiva 91/157/CEE do Conselho relativa às pilhas e acumuladores contendo determinadas matérias perigosas

Jornal Oficial $n^{\circ}$ L 264 de 23/10/1993 p. 0051 - 0052

Disponível em: <http://eurlex.europa.eu/smartapi/cgi/sga_doc?smartapi!celexapi!prod!CELEXnumdoc\&lg=PT\&n umdoc=391L0157\&model=guichett $>$. Acesso em: 15 out. 2005.

EUROPA - Europa Press Releases Rapid Environment: Commission proposes revised laws on recycling and use of hazardous substances in electrical and electronic equipment. IP/08/1878. Brussels, 3 December 2008. Disponível: 
$<$ http://europa.eu/rapid/pressReleasesAction.do?reference=IP/08/1878\&format=HTML $\underline{\text { \&aged }=0 \text { \&language }=E N \& \text { guiLanguage }=\text { enronic equipment }>}$. Acesso em: 15 out. 2008.

EC - European Commission -- Proposal for a DIRECTIVE OF THE EUROPEAN PARLIAMENT AND OF THE COUNCIL on waste electrical and electronic equipment (WEEE) (Recast) (Dec 2008). Brussels, 3.12.2008. Disponível em: <http://eurlex.europa.eu/LexUriServ/LexUriServ.do?uri=CELEX:52008PC0810:EN:NOT>; Acesso em: 22 Mar. 2012.

EUROPEAN COMISSION Environment. Recast of the WEEE Directive. (CE, Diretiva 75/422/CEE)- CE, Diretiva 91/156/CEE - Lei de Resíduos.

Disponível em: 〈http://ec.europa.eu/environment/waste/weee/index_en.htm〉. Acesso em: 22 Mar. 2012.

EUROPEAN PARLIAMENT AND THE COUNCIL. Restriction of Hazardous Substances. RoHS Recast -RoHS 2.0. RSJ Technical Consulting 2011 . DIRECTIVE 2011/65/EU OF THE EUROPEAN PARLIAMENT AND OF THE COUNCIL, of 8 June 2011, on the restriction of the use of certain hazardous substances in electrical and electronic equipment. (Text with EEE relevance). Directive 2011/65/EU - RoHS Recast. Decision 768/2008/EC - Module A Document 17217/10. Disponível em: $\langle$ http://register.consilium.europa.eu/pdf/es/11/st07/st07042.es11.pdf〉. Acesso em 14 ago. 2011.

EXAME (2011). A Universidade de São Paulo (USP), é a única representante latino-americana no ranking da Times Higher Education. Acesso em 15 nov. 2011. Disponível em: <http://exame.abril.com.br/carreira/guia-de-faculdades/noticias/rankingdas-200-melhores-universidades-do-mundo?page=9\&slug_name=ranking-das-200melhores-universidades-do-mundo>

ESPANHA - Real Decreto 208/2005, de 25 de fevereiro, sobre equipamentos elétricos e eletrônicos e a gestão de seus resíduos, publicado no Boletin Oficial do Estado (BOE n. 47,2005$)$.

ESPANHA. RD 943/2010 - de 23 de julio, por el que se modifica el Real Decreto 106/2008, de 1 de febrero, sobre pilas y acumuladores y la gestión ambiental de sus 
residues. BOE. Boletin Oficial del Estado, Núm. 189, jueves 5 de agosto de 2010 Sec. I. Pág. 68187.

ESPANHA, Ministerio de la Presidencia - REAL DECRETO 106/2008, de 1 de febrero, sobre pilas y acumuladores y la gestión ambiental de sus resíduos. Boletin Oficial do Estado num. 37 Martes 12 Feb. 2008. Disponível em: <http://www.boe.es/boe/dias/2008/02/12/pdfs/A07399-07410.pdf>. Acesso em: 2 nov. 2010.

ESPANHA, MINISTERIO DE LA PRESIDENCIA - Real Decreto 367/2010 sobre "sobre o livre acesso às atividades de serviços e seu exercício" modifica alguns artigos do RD 208/2005 de REEE. Boletin Oficial del Estado nº 75/2010.

EUROLEX, Directiva 93/86/CEE da Comissão de 4 de Outubro de 1993 que adapta ao progresso técnico a Directiva 91/157/CEE do Conselho relativa às pilhas e acumuladores contendo determinadas matérias perigosas

\section{Jornal Oficial no L 264 de 23/10/1993 p. 0051 - 0052}

Disponível em: <http://eurlex.europa.eu/smartapi/cgi/sga_doc?smartapi!celexapi!prod!CELEXnumdoc\&lg=PT\&n umdoc=391L0157\&model=guichett $>$. Acesso em: 15 out. 2005.

EUROPA - Europa Press Releases Rapid Environment: Commission proposes revised laws on recycling and use of hazardous substances in electrical and electronic equipment. IP/08/1878. Brussels, 3 December 2008. Disponível: $<$ http://europa.eu/rapid/pressReleasesAction.do?reference=IP/08/1878\&format=HTML \&aged $=0 \&$ language $=E N \&$ guiLanguage $=$ electronic equipment $>$. Acesso em: 15 out. 2008 .

EEA - European Environment Agency: About Environment and Health. Disponível em: <http://www.eea.europa.eu/themes/human/about -environment-and-health/>. Acesso em: 10 Nov. 2011

EUROPEAN COMISSION E. Recast of the WEEE Directive. (CE, Diretiva 75/422/CEE)- CE, Diretiva 91/156/CEE - Lei de Resíduos. Disponível em: <http://ec.europa.eu/environment/waste/weee/index_en.htm>. Acesso em: 2 ago 2011. 
EUROPEAN PARLIAMENT AND THE COUNCIL. Restriction of Hazardous Substances. RoHS Recast -RoHS 2.0. RSJ Technical Consulting 2011 . DIRECTIVE 2011/65/EU OF THE EUROPEAN PARLIAMENT AND OF THE COUNCIL, of 8 June 2011. Directive 2011/65/EU - RoHS Recast. Decision 768/2008/EC - Module ADocument 17217/10. Disponível em: <http://register.consilium.europa.eu/pdf/es/11/st07/st07042.es11.pdf>. Acesso em 14 ago. 2011.

EXAME (2011). A Universidade de São Paulo (USP), é a única representante latino-americana no ranking de Times Higher Education. Acesso em 15 nov. 2011. Disponível em: <http://exame.abril.com.br/carreira/guia-de-faculdades/noticias/rankingdas-200-melhores-universidades-do-mundo?page=9\&slug_name=ranking-das-200melhores-universidades-do-mundo>

FEAM . Diagnóstico da Geração de Resíduos Eletroeletrônicos no Estado de Minas Gerais. Belo Horizonte, junho de 2009. Acesso em: 02 Nov. 2011.

FLORENZ, K-H. Residuos de Aparatos Eléctricos y Electrónicos. Debates: Proyecto de recomendación para la segunda lectura respecto de la Posición del Consejo en primera lectura con vistas a la adopción de la Directiva del Parlamento Europeo y del Consejo sobre residuos de aparatos eléctricos y electrónicos (RAEE) (Texto refundido). 2 de agosto de 2011. Comisión de Medio Ambiente, Salud Pública y Seguridad Alimentaria. PE 469.957v01-00, 2 de agosto de 2011. Disponível em: <http://www.europarl.europa.eu/sides/getDoc.do?pubRef=//EP//TEXT+CRE+20110203 +ITEM-005+DOC+XML+V0//ES>. Acesso em 11 nov. 2011.

FLYGANSVÆR, B.M; GADDE, L-E; HAUGLAND, S.A. (2008). Coordinated action in reverse distribution systems, International Journal of Physical Distribution \& Logistics Management, Vol. 38 Iss: 1, pp.5 - 20.

FRANCO, R. G. F.; LANGE, L. C. Estimativa do fluxo dos resíduos de equipamentos elétricos e eletrônicos no município de Belo Horizonte, Minas Gerais, Brasil. Engenharia Sanitária e Ambiental. vol. 16 no.1; Rio de Janeiro Mar. 2011.

FONTE DE DADOS. A história da Apple, Steve Jobs e Steve Wozniak, 2011. Disponível em: www.fontededados.com. Acesso em 12 nov. 2011. 
FORESIGHT Institute. A Short History of Nanotechnology. Palo Alto, 2010.

Disponível em: 〈http://www.foresight.org/nano/history.html 2011〉. Acesso em 10 nov. 2011.

FONTE DE DADOS. A história da Apple, Steve Jobs e Steve Wozniak. Disponível em: <www.fontededados.com>. Acesso em 12 nov. 2011.

GANAPATI, P. First Functional Molecular Transistor Comes Alive. Gadget Lab. December 24, 2009.

GEFIM, 2004 - Universidade de São Paulo. Manual de Administração Patrimonial. 2004.

GIL, A. C. Como elaborar projetos de pesquisa. 4a . Ed. São Paulo: Atlas, 2008.

GÖETHE INSTITUTE. NACHHALTIGKEIT. Conceitos de Sustentabilidade.

Definição de sustentabilidade pela Comissão Brundtland. Disponível em:

<http://www.goethe.de/ges/umw/dos/nac/den/pt3106180.htm. Acesso em: 12 nov. 2011.

GÜNTHER, W. M. R. e GRIMBERG, E. Directrices para la gestión integrada y sostenible de residuos sólidos urbanos en América Latina y Caribe. 1 ed. São Paulo: Asociación Interamericana de Ingeniería Sanitaria y Ambiental - AIDIS, 2006.

GÖETHE INSTITUT. NACHHALTIGKEIT - Sustentabilidade - do modelo a implementação. Copyright: Goethe-Institut e. V., Online-Redaktion, 2008. Dr. Pascal Bader é relator do Ministério do Meio Ambiente de Baden-Württemberg. Tradução: Hedda Malina. Goethe-Institut e. V., Online-Redaktion. Março de 2008. <http://www.goethe.de/ges/umw/dos/nac/den/ptindex.htm>. Acesso em 28 set.2011.

GRC - Gremio de Recuperació de Catalunya. Aparatos eléctricos y electrónicos después de su vida útil. Revista del Gremi de Recuperació de Catalunya. $\mathrm{N}^{0} 54$, mayo de 2008. Disponível em: http://www.gremirecuperacio.org/pdf/revista/54.pdf. Acesso em 12 out. 2008.

GTZ - Deutsche Gessellschaft für Technische Zusammenarbeit. The Waste Experts: Enabling Conditions for Informal Sector Integration in Solid Waste Management. 
JACOBI, P. R. e BESEN, G. R. Gestão de resíduos sólidos em São Paulo: desafios da sustentabilidade. Estudos Avançados. Dossiê Sao Paulo Hoje.

Print versión. vol.25 no.71. São Paulo Jan./Apr. 2011. Disponível em:

http://www.scielo.br/scielo.php?pid=S0103-40142011000100010\&script=sci_arttext. Acesso em: 2 dec. 2011.

JORNAL OFICIAL DA UNIAO EUROPEIA. Reformulação da Diretiva 2002/95/EC (RoHS Recast, 2011), sobre a restrição do uso de certas substâncias perigosas nos EEE, $1^{\text {o }}$ de junho de 2011, Official Journal of the European Union, on July 1, 2011. A Diretiva RoHS 2.0 (DIRECTIVE 2011/65/EU OF THE EUROPEAN PARLIAMENT AND OF THE COUNCIL) revoga a Diretiva RoHS original, em vigor desde 2006 (CE, 2011).

KEENEY, R.L. (1992), Value-focused Thinking: A Path to Creative Decisionmaking, Harvard University Press, Cambridge, MA,

KNOWLEDGE Center - Nanotecnologia. Instituto Inovação, ser. 2005. Disponível em: www.institutoinovacao.com.br/downloads/inovacao_set05.pdf $>$. Acesso em 10 dec. 2011.

KHETRIWAL, D.S.; KRAEUCHI, P.; WIDMER, R. Producer responsibility for ewaste management: Key issues for consideration - Learning from the Swiss experience. Journal of Environmental Management. Volume 90, Issue 1, January 2009, Pages 153-165. Disponível em; <http://dx.doi.org/10.1016/j.jenvman.2007.08.019, How to Cite or Link Using DOI>. Acesso em 18 Jan. 2011.

KUEHR R; WILLIAMS E. Computers and the Environment: understanding and managing their Impacts. Eco-efficiency Industry and Science Series. Kluwer Academic and United Nations University Publisher. The Netherlands, 2003.

LAMBERT, R. Review of Business-University Collaboration. HM Treasury, London, 2003

LEE, L. T-S. The Pivotal Roles of Corporate Environment Responsibility, Industrial Management \& Data Systems, Vol. 112, 2012; Iss: 3. 
LINDHQVIST, T., Extended Producer Responsibility in Cleaner Production. The International Institute for Industrial Environmental Economics. Lund University, Lund, Sweden, 2000.

MEDINA, M. The World's Scavangers: salvaging for sustainable consumption and production. Lanham MD: Altamira Press, 2007.

MELO, J. L. P. A surpreendente Lei de Moore. Folha de Sao Paulo; 11 out. 2005.

Disponível em:

<http://www.universia.com.br/html/noticia/noticia_clipping_cgbfb.html >. Acesso em 12 Nov. 2011.

MEYER, H.W. A History of Electricity and Magnetism. The MIT PRESS. Boston, December 1971. $53 / 8$ x 8, $352 \mathrm{pp}$.

MILANEZ, B. Resíduos sólidos e sustentabilidade: princípios, indicadores e instrumentos de ação. 2002. Dissertação (Mestrado em Engenharia Urbana) Universidade Federal de Sao Carlos, Sao Carlos.

MONTERO, E.M. Impacto Ambiental "no visible" de los AEEs: fabricación y uso. In: JORNADAS GESTIÓN DE RESIDUOS DE APARATOS ELÉCTRICOS Y ELECTRÓNICOS (RAEEs), Cádiz, 18 de Junio de 2009 - Cátedra RELEC

NCM - Nordic Council of Ministers. Environmental Consequences of Incineration and Landfilling of Waste from Electrical and Electronic Equipment, Copenhagen, Temanord, 1995.

MOORE, G.E. Cramming more components onto integrated circuits. Rev Electronics. v. 38, n. 8, p. 114-117. Apr. 19, 1965.

MOORE, J. (2005) Seven recommendations for creating sustainability education at the university level: A guide for change agents, International Journal of Sustainability in Higher Education, Vol. 6 Iss: 4, pp.326 - 339

NOVA ELETRONICA. Computador. A história do computador pessoal. Disponível em: <www.novaeletronica.net/tutoriais/computador/computador.htm>. Acesso em: 11 nov. 2011. 
OECD - Organisation for Economic Co-operation and Development. Extended Producer Responsibility: A Guidance Manual for Governments. Paris, 2001.

OLIVEIRA, R. A. Responsabilidade pelo descarte indevido de lâmpadas fluorescentes. Observatório Eco - Direito Ambiental. 27 fevereiro, 2010. Disponível em: $<$ http://www.observatorioeco.com.br/responsabilidade-pelo-descarte-indevido-delampadas-fluorescentes/>. 18 nov. 2011.

ONU - Organização das Nações Unidas - Convenção da Basileia define a organização e o movimento de resíduos sólidos e líquidos perigosos. (BASEL, 1988). Disponível em:

$<$ http://www.basel.int/TheConvention/Overview/TextoftheConvention/tabid/1275/Defa ult.aspx>. Acesso em: 06 mar. 2011.

ONU - Organização das Nações Unidas - Conferência das Nações Unidas sobre o Meio Ambiente Humano. Declaração de Estocolmo sobre o ambiente humano. (Declaração de Estocolmo) [T2]. Estocolmo, junho/1972. Disponível em: <http://www.ufpa.br/npadc/gpeea/DocsEA/DeclaraAmbienteHumano.pdf>

ONU - Organização das Nações Unidas -1987 - Relatório Brundtland, Our Common Future - O Nosso Futuro Comum. Primeira- Ministra da Noruega, Gro Harlem Brundtland, Estocolmo, 1987. Disponível em: <http://www.un-documents.net/wcedocf.htm>. Acesso em 15 fev. 2011.

ÖKO Institut e.v. Institut für angewandte Ökologie. Institute for Applied Ecology. Fraunhofer IZM. Final Report. Adaptation to Scientific and Technical Progress under Directive 2002/95/EC - Evaluation of New Requests for Exemptions and/or http://rohs.exemptions.oeko.info/fileadmin/user_upload/RoHS_IV/RoHS_final_report_ May_2011_final.pdf. Acesso em: 2 nov. 2011.

OfiRAEE. Princípio da Responsabilidade extendida do produtor - Cached 4 Jan 2003 - EPR works through various types of producer responsibility. Thomas Lindquist (referred to as the father of EPR) has identified five basic ...Lund: IIIEE, Lund University and Rossem, Tojo and Lindqvist 2006 Extended ... Disponível em: <www.toxicslink.org/art-view.php?id=21>. Acesso em 15 Jan. 2012. 
OMS - Organização Mundial da Saúde. The World Health Report 2007. A safer future: global public health security in the $21^{\text {st }}$ century. Disponível em: <http://www.who.int/whr/2007/en/index.html>. Acesso em 11 nov. 2011.

OPS - Organización Panamericana de la Salud. Informe regional sobre la evaluación de los servicios de manejo de residuos sólidos en la Región de América Latina y el Caribe. Washington, D.C: OPS, 2005. Disponível em:

<http://register.consilium.europa.eu/pdf/en/11/st07/st07632.en11.pdf>. Acesso em 15 nov. 2011.

OPS, Organización Panamericana de la Salud. Determinantes Ambientales y Sociales de la Salud. Washington D.C.: OPS 2010. (Projeto BRA/92/017, 1996) (Modelo de gestão de resíduos sólidos para a ação governamental no Brasil: aspectos institucionais, legais e financeiro).

ORGALIME. Export of waste electrical and electronic equipment (WEEE): plenty of gold, and poison, too. Joint press release by the German Federal Ministry for Environment, Nature Conservation and Nuclear Safety (BMU). Röttgen and Flasbarth: Study shows need for action to promote ecological recycling. Disponível em: <http://www.orgalime.org/issues/weee.asp>. Acesso 15 nov. 2011.

PALACIOS, T. Nature | News \& Views. Applied physics: Nanowire electronics comes of age. Nature. N. 481, 152-153 (12 January 2012) doi: 10.1038/481152a. Published online 11 January 2012

POPULAÇÃO SUSTENTÁVEL. Consumismo. Disponível em: <http://populacaosustentavel.wordpress.com/consumismo/>. Acesso em: 15 out. 2011. PUBLIC CONSILIUM - EUROPA, 2011. Disponível em: <http://register.consilium.europa.eu/pdf/pt/11/st07/st07042-ad01.pt11.pdf>. Acesso em 12 Jan. 2012.

PARLAMENTO EUROPEU, Directiva 2008/98/CE del Parlamento Europeo y del Consejo de 19 de noviembre de 2008 sobre los residuos y por la que se derogan determinadas Directivas (Texto pertinente a efectos del EEE). Diario Oficial de la Unión Europea. España, 22.11.2008. 
PARLAMENTO EUROPEU. Diretiva RoHS 2002/95/CE do Parlamento Europeu e do Conselho, de 2003 jan. 27: relativa à restrição do uso de determinadas substâncias perigosas em equipamentos elétricos e eletrônicos. Jornal Oficial da União Europeia, 2003 fev.13. Disponível em: <www.rohs.gov.uk/>. Disponível em: <www.abinee.org.br/informac/arquivos/dir1.pdf>. Acesso em 11 de out. 2010.

PARLAMENTO EUROPEU. Diretiva WEEE 2002/96/CE do Parlamento Europeu e do Conselho, de 2003 jan. 27: relativa à restrição do uso de determinadas substâncias perigosas em equipamentos elétricos e eletrônicos. Jornal Oficial da União Europeia, 2003 fev.13. Disponível em: <www.abinee.org.br/informac/arquivos/dir1.pdf>. Acesso em 12 Jul.2010.

PERCHARDS 2007. WEEE legislation and compliance in the 27 EU Member

States. Selected aspects summarized from Perchards' online WEEE Information Service.

RASMUSSEN, B. A história da Apple, a marca da maçã. Disponível em: <http://www.tecmundo.com.br/2114-a-historia-da-apple-a-marca-da maca.htm\#ixzz1aleOIJix>. Acesso em: 12 nov. 2011.

RECUPERA. Aparatos Eléctricos y Electrónicos. Articulo no: 390. № de Revista: 54. abril 2008. Ramon Altadill. Electrorecyling S.A. Disponível em: <http://www.gremirecuperacio.org/15revista-ficha.asp?ficha=390>. Acesso em: 13 ago. 2010 .

REIDLER, N. M. V. L. e GÜNTHER, W. M. V. L. Impactos Ambientais e Sanitários causados por descarte inadequado de pilhas e baterias usadas. XXVIII Congresso Interamericano de Engenharia Sanitária e Ambiental, Cancún, 2002. Disponível em: <http://www.ecolmeia.com/pilhasebaterias/impacto_ambiental.pdf >. Acesso em: 12 jan. 2011.

REIDLER, N. M. V. L. Tendências de destinación de los aparatos eléctricos y electrónicos fuera de uso em La Provincia de Cádiz y em El Municipio de São Paulo - Brasil. In: Anais do X CONGRESO DEL MEDIO AMBIENTE - CONAMA 10 - Madrid, 22 a 26 de Nov. 2010. 
RELEC 05. Retos e hitos em la gestión de los RAEE. European Recycling Platform ERP. Ignácio Duque Oliart. Cátedra RELEC. Cádiz, UCA - Universidad de Cádiz. Septiembre 2005.

RELEC. La révision des directives RoHS et DEEE promete de longas debuts. Journal de l'environnement, 12/02/2010. Disponível em:

<http://www.journaldelenvironnement.net/fr/document/detail.asp?id=2573\&idThema=4 \&idSousThema=23\&type=JDE\&ctx=291> . Acesso em 12 fev. 2012.

RETS. RIP o potencial do descarte. Boletim RETS, 04/09/2009 - 14:51. Por Flavia Fascendini, com a colaboração de Maria Cruz Ciarniello. European Commission webpage on electrical and electronic equipment. Disponível em: $<$ http://ec.europa.eu/environment/waste/weee/index_en.htm $>$. Acesso em: 13 out. 2011. Disponível em: 〈http://www.rets.org.br/?q=node/117>.

REVERTIA. Última revisión de la directiva europea sobre RAEE. Vigo, 11 de agosto de 2010. Disponível em: http://revertia.com/ultima-revision-de-la-directivaeuropea-sobre-raee/. Acesso em 18 nov. 2011.

REVISTA DE SUSTENTABILIDADE. Coleta Seletiva de Eletrônicos passa na CCJ da Câmara de SP. Redação da Revista Sustentabilidade - última modificação Jun 02, 2011 05:25 PM (SÃO PAULO, CAMARA MUNICIPAL CCJ, PL066/2001).

RODRIGUEZ, B. Los cinco años de aplicación del RD 208/2005 (MARM-CCAAEELL-PRODUCTORES) - RELEC 10 - Granada 2010 - Secretaria de Estado de Cambio Climático. Dirección General de Calidad y Evaluación Ambiental - IX Jornadas de Reciclado de Aparatos Eléctricos y Electrónicos. RELEC'10 - Granada 18-19 nov.2010.

RELEC 05. Retos e hitos em la gestión de los RAEE. European Recycling Platform ERP. Ignácio Duque Oliart. Cátedra RELEC. Cádiz, UCA - Universidad de Cádiz. Septiembre 2005.

RELEC. La révision des directives RoHS et DEEE promet de longs débats. Journal de l'environnement, 12/02/2010. Acesso em out. 2010. Disponível em: 
<http://www.journaldelenvironnement.net/fr/document/detail.asp?id=2573\&idThema=4 \&idSousThema=23\&type=JDE\&ctx=291>

RETS. RIP o potencial do descarte. Boletim RETS, 04/09/2009 - 14:51. Por Flavia Fascendini, com a colaboração de Maria Cruz Ciarniello. European Commission webpage on electrical and electronic equipment. Disponível em:

<http://ec.europa.eu/environment/waste/weee/index_en.htm>. Acesso em: 13 out. 2011. Disponível em: 〈http://www.rets.org.br/?q=node/117〉.

REVERTIA. Última revisión de la directiva europea sobre RAEE. Vigo, 11 de agosto de 2010. Disponível em: <http://revertia.com/ultima-revision-de-la-directiva-europeasobre-raee/>. Acesso em 18 nov. 2011.

REVISTA DE SUSTENTABILIDADE. Coleta Seletiva de Eletrônicos passa na CCJ da Câmara de SP. Redação da Revista Sustentabilidade — última modificação Jun 02, 2011 05:25 PM (SÃO PAULO, CAMARA MUNICIPAL CCJ, PL066/2001).

RIGAMONTI, L.; GROSSO, M.; GIUGLIANO, M. Life cycle assessment for optimising the level of separated collection in integrated MSW management systems. Waste Management. Milano; Volume 29, Issue 2, February 2009, Pages 934-944

RODRIGUEZ, B. Los cinco años de aplicación del RD 208/2005 (MARM-CCAAEELL-PRODUCTORES) - RELEC 10 - Granada 2010 - Secretaria de Estado de Cambio Climático. Dirección General de Calidad y Evaluación Ambiental - IX Jornadas de Reciclado de Aparatos Eléctricos y Electrónicos. RELEC'10 - Granada 1819 nov. 2010.

SÁNCHEZ e CASTRO, 2011. Gestión y Minimización de Resíduos. 2ª edición. Fundación CONFEMETAL. Madrid, 2011.

SANDER, K. e SCHILLING, S. Optimierung der Steuerung und Kontrolle grenzüberschreitender Stoffströme bei Elektroaltgeräten / Elektroschrott Dieser Band ist auch auf Englisch verfügbar. Texte Nr. 11/2010 UBA-FB Nr: 001331. 
SÃO PAULO. - Decreto $\mathrm{N}^{\mathrm{o}}$ 54.645, de 5 de agosto de 2009. Secretaria de Meio Ambiente do Estado São Paulo, 119 (145) Diário Oficial Poder Executivo - Seção I quinta-feira, 6 de agosto de 2009.

SÃO PAULO. Projeto de lei $\mathrm{N}^{\mathrm{o}}$ : 66. Ano: 2011. Secretaria: Câmara Municipal. Publicação: 6/4/2011, Folha 93. Diário Oficial Municipal. Ementa: Dispõe sobre as diretrizes para a instituição de programa de coleta seletiva contínua de resíduos eletrônicos e tecnológicos, e dá outras providências. Disponível em: $<$ http://www.marcoaureliocunha.com.br/index.php?option=com_content\&view=article \&id=115:projeto-de-lei-662011-institui-o-programa-de-coleta-seletiva-continua-deresiduos-eletronicos-e-tecnologicos\&catid=2:leis-e-projetos \&Itemid=3>. Acesso em 15 out. 2011.

\section{SÃO PAULO. Lei Estadual No 12.300, de 16 de março de 2006, do Governo do}

Estado de São Paulo: institui a Política Estadual de Resíduos Sólidos e define princípios e diretrizes (São Paulo, Lei No 12.300, de 16-03-2006). Palácio dos Bandeirantes, aos 16 de março de 2006. Disponível em:

<http://www.ambiente.sp.gov.br/legislacao/estadual/leis/2006\%20Lei\%2012300.pdf>. Acesso em: 15 de out. 2011.

SÃO PAULO. Decreto No 54.645, de 5 de agosto de 2009. São Paulo, 119 (145) Diário Oficial Poder Executivo - Seção I quinta-feira, 6 de agosto de 2009. Publicado na Casa Civil, aos 5 de agosto de 2009.

SÃO PAULO, Secretaria de Estado de Meio Ambiente. Resolução SMA -024, de 31 de março de 2010. Define responsabilidade pós-consumo dos produtores, distribuidores e importadores. Estabelece a relação de produtos geradores de resíduos sólidos de significativo impacto ambiental para os fins de delimitação da responsabilidade pósconsumo, já prevista no Decreto n ${ }^{\circ}$ 54.645, de 05 de agosto de 2009, regulamentador da Lei Estadual n 12.300, de 16 de março de 2006 - Política Estadual de Resíduos Sólidos de São Paulo. Disponível em: < $<$ http://www.anfalpet.org.br/portal/index.php?option=com_content\&view=article\&id=1 85:resolucao-no-24-de-31-de-marco-de-2010\&catid=16:noticias-externas\&Itemid=1> . Acesso em: 12 mar. 2011. 
SÃO PAULO. Lei Estadual No 13.576, de 6 de julho de 2009. Institui normas e procedimentos para a reciclagem, gerenciamento e destinação final de lixo tecnológico. Diário Oficial do Estado de São Paulo, 7 de jul. 2009. Disponível em: <http://www.fiesp.com.br/sindicaljuridica/informes/2009_07_06_lei_estadual_13576_2009.ntc>.Acesso em: 12 nov.2011.

SÃO PAULO. Lei Estadual No 14.470, de 22 de junho de 2011. Dispõe sobre a separação dos resíduos recicláveis descartados pelos órgãos e entidades da administração pública estadual, na forma que especifica. Diário Oficial do Estado de São Paulo, 23 jul. 2011.Disponível em:

<http://www.al.sp.gov.br/repositorio/legislacao/lei/2011/lei\%20n.14.470,\%20de\%2022. 06.2011.htm>. Acesso em 12 nov. 2011.

SÃO PAULO. Secretaria do Meio Ambiente do Estado de São Paulo. São Paulo. Resolução no. 131, de 30 de dezembro de 2010. Diário Oficial do Estado de São Paulo, 31 dez. 2010. Determina que, de acordo com a Política Nacional de Resíduos Sólidos: ficam obrigados os fabricantes, distribuidores e importadores de produtos eletroeletrônicos e lâmpadas fluorescentes (entre outros produtos especiais) a...Disponível em: <http://lixoeletronico.org/system/files/2010_res_est_sma_131.pdf> Acesso em: 15 de jun. 2010.

SÃO PAULO. Projeto de Lei $\mathrm{N}^{\mathrm{o}}$ : 575. Ano: 2009. Secretaria: Câmara Municipal. Publicação 9/9/2009. Folha 57. Ementa: Dispõe sobre a obrigatoriedade de coleta e destinação final ambientalmente adequada, após sua vida útil, de produtos considerados resíduos urbanos e caracterizados como lixo eletrônico e tecnológico e dá outras providencias. Disponível em: <http://www.nossasaopaulo.org.br/portal/node/9241>. Acesso em 4 Apr. 2011.

SÃO PAULO (PMSP). Projeto de Lei N ${ }^{\mathrm{o}}$ : 66 Ano: 2011 Secretaria: CÂMARA. Publicação: 06/04/2011, Folha 93. Diário Oficial Municipal Ementa: Dispõe sobre diretrizes para a instituição do Programa de Coleta Seletiva Contínua de Resíduos Eletrônicos e Tecnológicos e dá outras providências.

SÃO PAUlO (Estado). Secretaria do Meio Ambiente. Projeto BRA/92/017. Gestão e Tecnologias de Tratamento de Resíduos: modelos de gestão de resíduos sólidos para a 
ação governamental no Brasil: aspectos institucionais, legais e financeiros / Solid Waste management model for a government action un Brazil: instituctional, legal and financier aspects. Sao Paulo, 1996. [157] p.

SÃO PAULO. Secretaria de Estado de Meio Ambiente. Resolução SMA-038 de 02 de agosto de 2011. Estabelece a relação de produtos geradores de resíduos de significativo impacto ambiental, para fins do disposto no artigo 19, do Decreto Estadual n ${ }^{\circ} 54.645$, de 05.08.2009, que regulamenta a Lei Estadual no 12.300, de 16.03.2006, e dá providências correlatas. Gabinete do Secretario. Publicada no Diario Oficial do estado de São Paulo, de 03-08-2011 Seção I Pag.46-47.

SÃO PAULO, Secretaria de Estado de Meio Ambiente. Resolução SMA -024, de 31 de março de 2010. Define responsabilidade pós-consumo dos produtores, distribuidores e importadores. Estabelece a relação de produtos geradores de resíduos sólidos de significativo impacto ambiental para os fins de delimitação da responsabilidade pósconsumo, já prevista no Decreto n ${ }^{\circ}$ 54.645, de 05 de agosto de 2009, regulamentador da Lei Estadual n 12.300, de 16 de março de 2006 - Política Estadual de Resíduos Sólidos de São Paulo. Disponível em: <

$<$ http://www.anfalpet.org.br/portal/index.php?option=com_content\&view=article\&id=1 85:resolucao-no-24-de-31-de-marco-de-2010\&catid=16: noticias-externas\&Itemid=1> . Acesso em: 12 mar. 2011.

SÃO PAULO. Lei Estadual No 13.576, de 6 de julho de 2009. (Projeto de lei no 33/2008, do Deputado Paulo Alexandre Barbosa - PSDB). Institui normas e procedimentos para a reciclagem, gerenciamento e destinação final de lixo tecnológico. Disponível em: <http://www.fiesp.com.br/sindicaljuridica/informes/2009_07_06_lei_estadual_13576_2 009.ntc>. Acesso em: 12 nov.2011.

SÃO PAULO. Projeto de Lei $N^{0}: 575$. Ano: 2009. Secretaria: Câmara Municipal. Publicação 9/9/2009. Folha 57. Ementa: Dispõe sobre a obrigatoriedade de coleta e destinação final ambientalmente adequada, após sua vida útil, de produtos considerados resíduos urbanos e caracterizados como lixo eletrônico e tecnológico e dá outras providencias. Disponível em: <http://www.nossasaopaulo.org.br/portal/node/9241>. Acesso em 4 Apr. 2011. 
SÃO PAULO (PMSP). Publicação $N^{0}$ : 92608. Ano: 2011. Secretaria: CAMARA MUNICIPAL DE SÃO PAULO. Diario Oficial do Municipio de São Paulo.

26/8/2011, Folha 3. Ementa: (extrato) Acordo de Cooperação -PMSP/Associação Brasileira de Empresas de Limpeza Publica e Resíduos Especiais -Ações conjuntas. Projeto Piloto: Sistema de Logística - Residuos de Equipamentos elétricos e Eletrônicos.

SÃO PAULO - USP - Universidade de São Paulo. Resolução № 5493, de 18 de dezembro de 2008. Retificada em 07.01 e 10.02.2009. Altera dispositivos do SÃO PAULO - USP - Universidade de São Paulo. RESOLUÇÃO No 5498, DE 23 DE dezembro de 2008. (Alterada pela Resolução 5871/2010). Dispõe sobre a implantação das Coordenadorias dos Campi e do Quadrilátero Saúde/Direito da USP (versão consolidada). Diario Oficial do Estado de São Paulo, de 24.12.2008.

SÃO PAULO - USP - Universidade de São Paulo. Resolução No 5492, de 18 de dezembro de 2008. Altera dispositivos do Estatuto da Universidade de São Paulo. D. O. E. - 23.12.2008.

SCHMIDT, C. W. Unfair Trade e-Waste in Africa. Journal List. Environ Health Perspect. Apr. 2006; 114(4): A232-A235.

SEIFFERT, M. E. B. Gestão Ambiental: instrumentos, esferas de ação e educação ambiental. São Paulo: Atlas S.A., 2007.

SILCON Ambiental . Concluída última etapa que modifica normas de produção e descarte de pilhas. Rev. Envolverde /MMA. Brasília, 2008 ago 13. [acesso em 16/12/2008]. Disponível em: <http://www.silcon.com.br/category/combate-apirataria/>. Acesso em 13 out.2010.

STEPHENS, J.C. et al. Higher education as a change agent for sustainability in different cultures and contexts. International Journal of Sustainability in Higher Education, 9 (3) (2008), pp. 317-338

SILCON Ambiental . Concluída última etapa que modifica normas de produção e descarte de pilhas. Rev. Envolverde /MMA. Brasília, 2008 ago 13. [acesso em 
16/12/2008]. Disponível em: <http://www.silcon.com.br/category/combate-apirataria/>. Acesso em 13 out.2010.

SÁNCHEZ e CASTRO, 2011. Gestión y Minimización de Resíduos. $2^{\mathrm{a}}$ edición. Fundación CONFEMETAL. Madrid, 2011.

SANDER, K. e SCHILLING, S. Optimierung der Steuerung und Kontrolle grenzüberschreitender Stoffströme bei Elektroaltgeräten / Elektroschrott Dieser Band ist auch auf Englisch verfügbar. Texte Nr. 11/2010

UBA-FB Nr: 001331.

TEIXEIRA, E. As três metodologias. Vozes. Belem, 2005

TELECO. Seção: Telefonia celular. Estatísticas de Celulares no Brasil. Disponível em: $<$ http://www.teleco.com.br/ncel.asp〉. Acesso em: 15 fev. 2012

U.N. United Nations. UN Documents. Gathering a body of global agreements. Report of the World Commission on Environment and Development: Our Common Future.

Brundtland Report, from the United Nations World Commission on Environment and Development (WCED). Transmitted to the General Assembly as an Annex to document A/42/427 - Development and International Co-operation: Environment. UN, Stockholm, 1987.

UBA - Umwelt Bundes Amt. By Fotini Mavromati, Theresa Pfeifer, Martin Stallmann. Export of waste electrical and electronic equipment (WEEE): plenty of gold, and poison, too. Röttgen and Flasbarth: Study shows need for action to promote ecological recycling. Joint press release by the German Federal Ministry for Environment, Nature Conservation and Nuclear Safety (BMU). Disponível em:

<www.umweltbundesamt.de.> Acesso em: 16 nov. 2011.

UCA - Universidad de Cádiz. Aparatos eléctricos y electrónicos. Disponível em: http://// uca.es/grup-invest/cit/mas_AEE.htm. Acesso em: 21 ago. 2011.

UCA. Universidad de Cádiz. História de la UCA. Disponível em: $<$ http://www.uca.es/es/nuestra-universidad/historia-de-la-uca〉. Acesso em $14 \mathrm{dec}$. 2011. 
UCA - Universidad de Cádiz. Estatutos de La Universidad de Cádiz: aprobados por acuerdo del Claustro Constituyente de 9 de julio de 2003, conforme AL acuerdo del Consejo de Gobierno de La Junta de Andalucía, de 17 de junio de 2003. Modificados por acuerdo del Claustro Universitario, de 13 de octubre de 2004, conforme a La Disposición Transitoria Septima de La Ley 15/2003, de 22 de noviembre, Ley Andaluza de Universidades. Cádiz, 2004.

USP. USP em números. Anuário Estatístico da USP 2010. Base de dados 2009. Acesso em 15 de jun. 2011. Disponível em:

<http://www.usp.br/internacional/home.php?id_cont=28\&idioma=pt >

USP - Manual de Administração Patrimonial. Manual elaborado pela COMPATRIM - Subcomissão de Patrimônio; GEFIM - Gestão Financeira e de Materiais (Atualização 2010).

USP - Universidade de São Paulo. Manual de Administração Patrimonial. Elaborado pela Subcomissão de Patrimônio - GEFIM. São Paulo, 2004.

USP (a) - Universidade de São Paulo. RESOLUÇÃO No 5492, de 18 de dezembro de 2008; Diário Oficial do Estado - 23.12.2008. Disponível em:

<http://www.usp.br/leginf/resol/r5492m.htm>. Acesso em: 22 de fev. 2012

USP (b)- Universidade de São Paulo. RESOLUÇÃO Nº 5493, de 18 de dezembro de 2008 (retificada em 07.01 e 10.02.2009) Diário Oficial do Estado - 23.12.2008.

Disponível em: <http://www.usp.br/leginf/resol/r5493m.htm>. Acesso em: 22 de fev. 2012

USP (c) - Universidade de São Paulo. RESOLUÇÃO No 5498, de 23 de dezembro de 2008. Diário Oficial do Estado de 24.12.2008) (Alterada pela Resolução 5871/2010).

Dispõe sobre a implantação das Coordenadorias dos Campi e do Quadrilátero Saúde/Direito da USP. Disponível em: http://www.pcarp.usp.br/pages/congest/REUSP5498.PDF. Acesso em 12 fev. 2012. USP - Manual de Administração Patrimonial. COMPATRIM - Subcomissão de Patrimônio; GEFIM - Gestão Financeira e de Materiais (Atualização 2010). 
VAN WYNSBERGHE, R.; MOORE, J.; TANSEY, J.; CARMICHAEL, J. (2002), Towards community engagement: six steps to expert learning for future scenario development. Futures, Vol. 35 No.3, pp.203-19.

VALlE, C. E. Qualidade Ambiental: ISO 14.000. $7^{a}$ Edição. São Paulo: Editora SENAC São Paulo, 2008.

VEGA, C. A., OJEDA-BENITEZ, S, RAMÍREZ-BARRETO, M.E. Mexican educational institutions and waste management programmes: a University case study. Resources, Conservation and Recycling, 39, 283-296; 2003.

VENTURA, M. M. O Estudo de Caso Como Modalidade de Pesquisa. Pedagogia Médica. Ver. SOCERJ. Rio de Janeiro, set./ out. 2007; 20 (5): 383-386

VOET, E., V. D. \& GUINÉE, J. B. \& HAES, H. A.

Heavy metals: a problem solved? Methods and models to evaluate policy strategies for heavy metals. Environment \& Policy, 22. Dordrecht: Kluwer academic publishers, The Netherlands, 2000.

WEEE/RoHS Revision (PARLAMENTO EUROPEU, 2002), iniciado em 2009 e com finalização prevista para 2011 (COUNCIL OF THE EUROPEAN UNION, 2009). Disponível em: 〈http://export.gov/europeanunion/weeerohs/rohsrevision/index.asp> <http://export.gov/europeanunion/weeerohs/weeeinformation/index.asp>. Acesso em 12 dec. 2011.

WEENEN, H.V. Towards a vision of a sustainable university. International Journal of Sustainability in Higher Education, Vol. 1 Iss: 1, pp.20 - 34. University of Amsterdam, The Netherlands, 2000.

\section{WHO - OMS. New and emerging environmental threats to human health.}

IMCHE/1/CP6 19.06.2008. Biblioteca Virtual de Saúde. Disponível em: <http://www.unep.org/health-env/pdfs/TD-New-and-emerging-threats.pdf>. Acesso em: 13 nov. 2010.

WIDMER, R. et al. Global perspectives on e-waste: Environmental Impact Assessment Review. Elsevier. Oct. 2001; 19 (5):380-90. 
WIDMER, R; ET AL. Global perspectives on e-waste. Environmental Impact Assessment Review. 25 (2005) 436-458. Disponível em:

<www.elsevier.com/locate/eiar>. Acesso em 25 jan. 2012.

YIN, R. Estudo de caso: planejamento e métodos. 2a ed. Porto Alegre: Bookman; 2001 .

ZHANG, N; WILLIAMS, I.D.; KEMP. S; SMITH, N.F. Greening academia:

Developing sustainable waste management at Higher Education Institutions. Waste

Management. Volume 31, Issue 7, July 2011, Pages 1606-1616

ZICKUHR, K. Generations and their gadgets. Pew Research Center's Internet \& American Life Project. Washington D.C. February 3, 2011. Disponível em: <http://pewinternet.org/Reports/2011/Generations-and-gadgets.aspx>. Acesso em 15 fev. 2012. 


\section{ANEXO I \\ CONCEITOS DE ADMINISTRAÇÃO PATRIMONIAL}

Alguns conceitos são fundamentais para entender o processo de administração patrimonial da IES (GEFIM, 2004; GEFIM-COMPATRIM, 2010).

- Alienação: procedimento de transferência da posse e propriedade de um bem, por meio de venda, doação ou permuta.

- Alteração de característica: procedimento pelo qual é efetuada a alteração das características originais, provenientes da necessidade de divisão, supressão de partes, aumento ou redução de medidas, resultando em novo número de bem.

- Avaliação: procedimento para incorporação de bens patrimoniáveis que se encontram na Unidade, com ou sem origem.

- Bens de Terceiros: é todo material permanente ingressado na Universidade através de contrato de CESSÃO DE USO/DEPÓSITO, ou quando o órgão financiador é o detentor da propriedade do bem.

- Bens do Ativo Permanente: aqueles que, em razão de seu uso contínuo, tem durabilidade e não perde sua identidade física.

- Bens de Consumo: material de consumo e peças de reposição que não fazem parte do ativo permanente e são bens não passiveis de incorporação.

- Comodato: empréstimo gratuito de bem duráveis que devem ser restituídos no tempo convencionado, ou recebidos por doação.

- Convênio: procedimento para incorporação de bens adquiridos com verbas de outras entidades em concordância com ambas as partes.

- Depósito: local de "trânsito" de bens permanentes, onde se guarda o bem até sua destinação final. 
- Disponibilidade: procedimento pelo qual o usuário informa o desuso/inservibilidade do bem. Nota: A informação permanecerá no SIAP por um período de 15 dias.

- Doação: entrega gratuita de direito de propriedade, com liberalidade do doador. Quando a doação estiver estabelecida no respectivo termo de doação, a mesma será classificada como clausulada.

- Etiquetagem: identificação física do bem através da atribuição de número patrimonial, por meio de etiqueta.

Nota: sempre que possivel, deve-se fixar uma etiqueta em lugar visivel e outra oculta, como medida de segurança, tendo a precaução necessária para que não seja afetado o funcionamento do bem. Quando não for possível a fixação da etiqueta, adotar outros meios para identificação do bem: como pintura, gravação, etc. Nenhum bem incorporado ao patrimônio deve ficar sem número de identificação.

- Incorporação de bens: pode ser por compra (quando o bem patrimoniável é adquirido via empenho) e por convenio (aquisição com verbas de outras entidades).

- Levantamento Físico/Inventário: levantamento e identificação dos bens e locais, visando comprovação de existência física, integridade das informações contábeis e identificação do usuário responsável (o inventário físico deverá ser efetuado anualmente).

- Localização Física: identificação do local, situado ou não nos Campi, registrado no cadastro de bens imóveis da Universidade, onde se encontram os bens móveis.

- Motivos de baixa: o motivo da baixa deve ser registrado no SIAP e pode ser por obsolescência, indevida incorporação em exercício anterior, sinistro, permuta, venda direta e/ ou leilão, furto e/ou roubo, extravio, quebra ou avaria.

- Patrimônio: conjunto de bens, direitos e obrigações suscetíveis de apreciações econômicas, obtidas através de compra, doação ou outra forma de aquisição, devidamente identificado e registrado.

- Permuta: troca permitida exclusivamente entre órgãos ou entidades da Administração Pública. O processo necessita de autorização do dirigente da unidade.

- Reincorporação: incorporação de um bem baixado. 


\section{- Registro de bens móveis:}

a. Bens de Terceiros, Convênios e Outros: procedimento para todo material permanente ingressado na Universidade através de contrato de CESSÃO DE USO/DEPÓSITO, ou quando o órgão financiador é o detentor da propriedade do bem. O mesmo empresta para a Universidade por um tempo determinado.

b. Em Poder de Terceiros, Convênios e Outros: procedimento para registro de um bem patrimoniado utilizado por terceiros, fora da Universidade.

- Baixa de bens móveis: de acordo com Portaria de Delegação de Competência Portaria GR nº 4685 de 23/01/2010:

a. Bens em condições de uso: disponibilizar para consulta da Universidade por 15 dias, através do Sistema MERCURIO.

b. Bens sem condições de uso: cabe ao usuário especificar a condição do bem, o qual deverá ser baixado como inservível. O processo necessita de autorização do dirigente da unidade e essa ação não é permitida para bens de terceiros.

c. Bens de Terceiros: em casos especiais, o responsável pelo bem deverá entrar em contato com a entidade ou Órgão financiador, solicitando a autorização para proceder à baixa patrimonial (após a finalização do processo sindicância).

d. Por Término da Cessão de Uso: procedimento para baixa de bens patrimoniais em que, ao término do projeto, a entidade financiadora ou pessoa física não concede a continuidade da utilização dos bens.

e. Por Descaracterização: procedimento para a baixa de bens patrimoniais que foram descaracterizados da condição de permanente da instituição.

f. Por Doação: procedimento para baixa de bens patrimoniais doados para entidades declaradas de utilidade pública (Entidades Filantrópicas), órgãos ou entidades da administração pública (Órgãos Públicos), permitida exclusivamente para fins e uso de interesse social, sem fins lucrativos.

g. Para o CEDIR (Centro de Descarte e Reuso de Resíduos de Informática): procedimento para baixa de bens patrimoniais do grupo de informática e telecomunicações, em condições de uso ou não.

Nota: Os bens ficam disponíveis por 15 dias na página web do SIAP e após esse período, devem ser encaminhados ao CEDIR, de acordo com as normas de entrega do referido centro. 
Nota: Os bens dos grupos de informática e telecomunicações não poderão ser baixados nesta modalidade. Os equipamentos provenientes de convênios, onde os projetos são realizados fora do âmbito da Universidade, só poderão ser doados a Organizações Públicas e fica dispensada sua divulgação no Sistema Mercúrio.

- Mudança de Local: procedimento pelo qual se transfere um bem de um Setor para outro, dentro da mesma Unidade.

- Mudança de Responsabilidade: procedimento pelo qual se transfere a responsabilidade sobre os bens, nas mudanças de seus detentores.

- Transferência: procedimento pelo qual se desloca fisicamente um bem de uma Unidade para outra.

- Upgrade: atualização tecnológica, mas sem a sua transformação física.

- Usuário Responsável ou Detentor: aquele que detém o bem sob sua guarda (conforme lei 4.320, artigo 94 e Portaria GR 2991 de 1996 


\section{ANEXO II \\ Manual de Procesos del Área de Economía Versión 1.1.}

\subsubsection{FICHA DE PROCESO}

\begin{tabular}{|c|c|}
\hline $\begin{array}{l}\text { Nombre del } \\
\text { proceso }\end{array}$ & PATRIMONIO (versión 1.0. 27/02/2008) \\
\hline Descripción & $\begin{array}{l}\text { Gestión del Patrimonio de la Universidad de Cádiz, tanto de } \\
\text { bienes inmuebles como muebles que forman parte del } \\
\text { inmovilizado. }\end{array}$ \\
\hline Misióniobjetivo & $\begin{array}{l}\text { Gestionar el Patrimonio de la Universidad de Cádiz, } \\
\text { conociendo en todo momento su composición, ubicación y } \\
\text { valoración, ejecutando los expedientes patrimoniales que } \\
\text { sean precisos. }\end{array}$ \\
\hline Responsable & $\begin{array}{l}\text { Jefe del Servicio de Gestión Económica, Contrataciones y } \\
\text { Patrimonio. }\end{array}$ \\
\hline Destinatario & $\begin{array}{l}\text { Equipo de Gobierno, Decanos y Directores de Centro, } \\
\text { Directores de Departamento y P.A.S. con funciones } \\
\text { relacionadas con el inventario. }\end{array}$ \\
\hline IniciolFin & $\begin{array}{l}\text { Inicio: Necesidad de adquirir derechos sobre bienes } \\
\text { inmuebles o de disponer de bienes muebles o inmuebles. } \\
\text { Fin: El proceso puede finalizar de } 6 \text { formas distintas: en el } \\
\text { caso de los bienes inmuebles: finalización del contrato de } \\
\text { arrendamiento, enajenación, finalización de la adscripción } \\
\text { provisional o reversión de la cesión de uso; en el caso de los } \\
\text { bienes muebles: retirada a vertedero o enajenación. }\end{array}$ \\
\hline Entr & $\begin{array}{l}\text { Petición de retirada de mobiliario, solicitud de mobiliario de } \\
\text { segunda mano, petición de inicio de algún expediente } \\
\text { patrimonial, petición de modificación de la base de datos, } \\
\text { petición de información sobre la situación patrimonial de } \\
\text { algún elemento del inmovilizado, etc. }\end{array}$ \\
\hline Salidas & $\begin{array}{l}\text { Retirada o entrega del mobiliario, ejecución de expedientes } \\
\text { patrimoniales, entrega de la información requerida, etc. }\end{array}$ \\
\hline Indica & $\begin{array}{l}\text { 1. Media de dias de respuesta a los CAU dirigidos a la } \\
\text { Unidad de Patrimonio en materia de inventario. } \\
\text { 2. Grado de satisfacción con el servicio de reasignación } \\
\text { de mobiliario. }\end{array}$ \\
\hline Registros & $\begin{array}{l}\text { Contenido de los diferentes C.A.U. recibidos en la Unidad de } \\
\text { Patrimonio. }\end{array}$ \\
\hline $\begin{array}{l}\text { Procedimientos } \\
\text { asociados }\end{array}$ & $\begin{array}{l}\text { Mantenimiento de las tablas del módulo de Inventario de } \\
\text { UXXI - Económico. } \\
\text { Definición y codificación de nuevos espacios. } \\
\text { Tramitación de expedientes de enajenación. } \\
\text { Tramitación de expedientes de cesión. } \\
\text { Tramitación de expedientes de arrendamiento. } \\
\text { Tramitación de expedientes de afectación/desafectación. } \\
\text { Tramitación de expedientes de adscripción provisional. } \\
\text { Tramitación de expedientes de adquisición de cesión de uso. } \\
\text { Catalogación y reutilización del mobiliario de segunda mano. } \\
\text { Inventario de bienes inmuebles. } \\
\text { Mantenimiento de la página web de Patrimonio. }\end{array}$ \\
\hline $\begin{array}{l}\text { Ap } \\
\text { inf }\end{array}$ & Universitas $\times X \mid$ Económico - Módulo Inventario. \\
\hline
\end{tabular}




\section{APÊNDICE I}

\section{ROTEIRO PARA ORIENTACAO DOS GRUPOS DE TRABALHO NO WORKSHOP PARA APRESENTACAO DO DIAGNOSTICO}

1) Em sua área de atuação, quais os procedimentos adotados com relação aos REEE que poderiam ser mudados, para facilitar seu trabalho?

2) Quais as maiores dificuldades encontradas em relação aos REEE, em sua área de atuação?

3) Em sua opinião, quais as dificuldades para que ocorra maior integração entre os envolvidos com a questão dos REEE?

4) Um curso de capacitação/treinamento em sua área de atuação poderia ajudar para desempenhar melhor a sua função?

5) Quais as dificuldades em se fazer a segregação dos materiais, antes de seu descarte?

6) Qual o procedimento adotado para a destruição de dados sigilosos, antes do descarte dos REEE em sua unidade?

7) Qual o critério adotado em sua unidade, para classificar um bem como patrimoniável ou não patrimoniável?

8) Quais as dificuldades encontradas no armazenamento dos bens baixados e da sucata, até sua retirada?

9) Como é decidido o destino dos bens baixados e da sucata em sua unidade?

10) Como usuário do Sistema Mercúrio, quais as dificuldades encontradas? Há alguma sugestão para melhorar o sistema?

11) Em sua opinião, quais as questões que devem ser consideradas na adoção de ações conjuntas, para a gestão integrada dos REEE no Quadrilátero?

12) Comentários e sugestões a acrescentar. 


\section{APÊNDICE II}

Check list para avaliação dos locais de destino - visitas técnicas

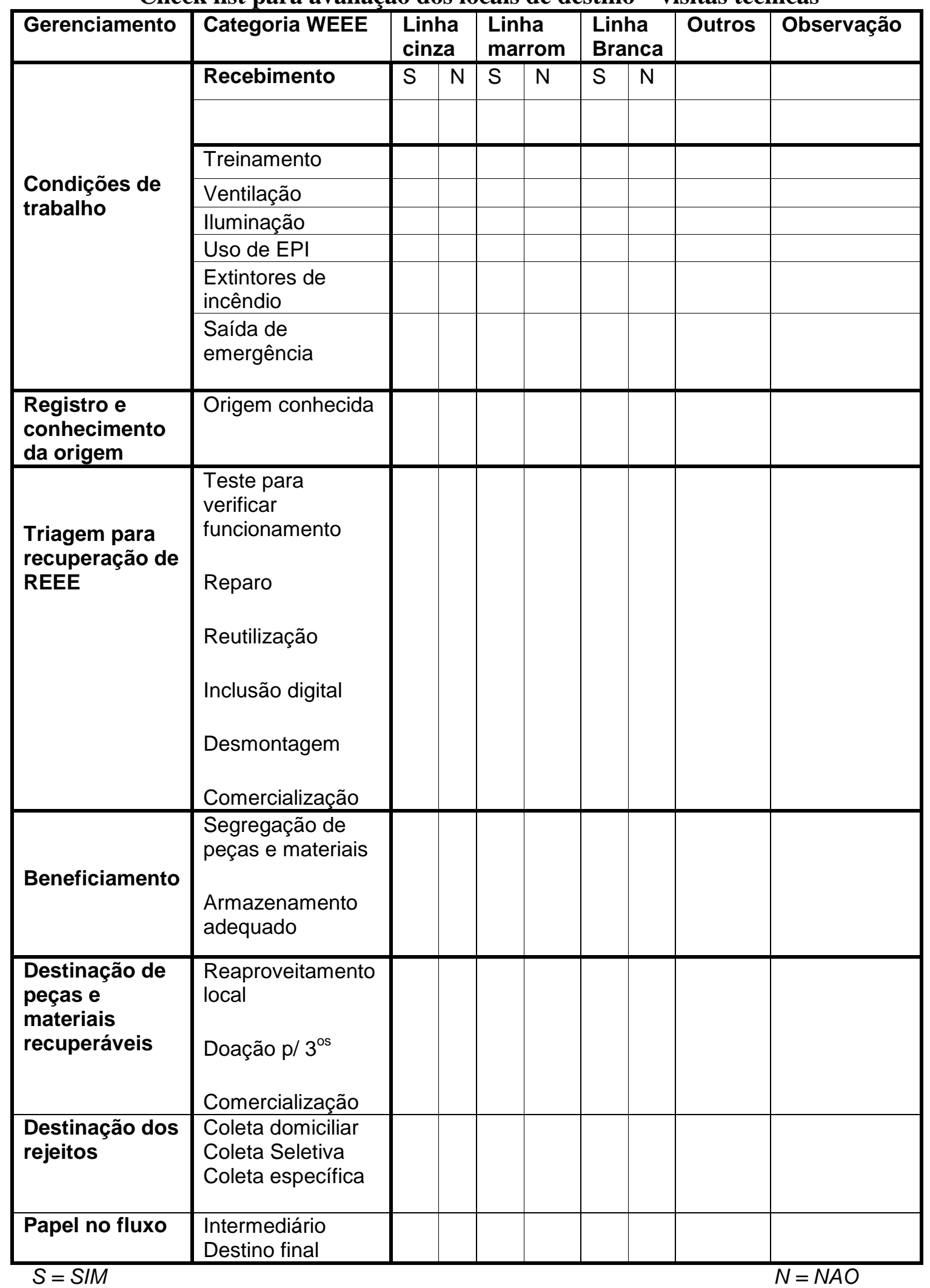




\section{APÊNDICE III}

\section{Roteiro estruturado de visita técnica aos locais de destino de REEE}

Nome da Empresa:

Data:

Nome do entrevistado:

Cargo/Função:

Descrição da empresa (instalações e constituição):

Numero de empregados:

Equipamentos existentes:

1. Quais os tipos de EEE/componentes comercializados e/ou reciclados?

2. Qual a atividade principal da empresa - o que a empresa faz com relação a equipamentos ou componentes? (desmonta, segrega, etc.?)

3. Qual o foco de mercado principal da empresa para compra e venda, ou prestação de serviço: particulares, outras empresas (de quais setores, fabricantes de EEE (identificar entrada e saída de materiais).

4. Quais os procedimentos de comercialização de materiais que são vendidos ou encaminhados para reciclagem ou remanufatura?

5. Quantidade aproximada de equipamentos / componentes comercializados/ reciclados por mês. Capacidade instalada de processamento (dia, mês)?

6. Qual o percentual de materiais ou componentes recuperados?

7. Quais os processos utilizados? 
8. A empresa possui um Programa de Prevenção de Riscos Ambientais - PPRA visando à preservação da saúde e da integridade dos trabalhadores? Quais são as medidas de controle e proteção individual e coletiva adotadas?

9. Qual a destinação de materiais cujo aproveitamento ou comercialização não seja possível?

10. Quais são esses materiais rejeitados e por qual motivo?

11. A atuação da empresa é regional, nacional ou internacional?

12. Quais os fatores atuais que dificultam a atividade da empresa?

13 Quais os tipos de licença necessários à operação da empresa? A empresa possui essas licenças?

14. A empresa possui certificação ISO-9000 ou ISO-14.000?

15. De que forma a aprovação da PNRS, com a obrigatoriedade da logística reversa ou uma Resolução CONAMA para os REEE impactarão nos negócios da empresa?

16. Já existe alguma articulação com os fabricantes nesse sentido 


\section{APENDICE IV}

\section{ALGUMAS EMPRESAS REGISTRADAS OFICIALMENTE COMO RECICLADORAS DE REEE NO BRASIL}

SINCTRONICS - Sorocaba, SP

UMICORE - Guarulhos, SP

SUZAQUIM - Suzano, SP

ESSENCIS - Nordeste, PR

TCG Recycling - Americana, SP

Cimélia - Campinas, SP

Baterias Pioneiro - Treze Tílias, SC

Pioneiro Ecometais - Agua Doce, SC

RECITEC - Bento Leopoldo (MG).

SIR Company - São Paulo, SP

Interamerican Ltda. - São Bernardo do Campo, SP

Lorene Importação e Exportação Ltda. - São Paulo, SP

OXIL- Manufatura Reversa - Paulínia, SP

Sanlien Exportação. Ltda. - São Paulo, SP

Sucata Eletrônica - São Paulo, SP

Target Trading S.A - São Paulo, SP 